Portland State University

PDXScholar

Master of Environmental Management Project

Reports

Environmental Science and Management

Fall 2017

\title{
Johnson Creek Bacteria TMDL Implementation: Status and Trend Analysis Study
}

John Gala

Portland State University

Follow this and additional works at: https://pdxscholar.library.pdx.edu/mem_gradprojects

Part of the Environmental Studies Commons, and the Water Resource Management Commons Let us know how access to this document benefits you.

\section{Recommended Citation}

Gala, John, "Johnson Creek Bacteria TMDL Implementation: Status and Trend Analysis Study" (2017).

Master of Environmental Management Project Reports. 32.

https://pdxscholar.library.pdx.edu/mem_gradprojects/32

https://doi.org/10.15760/mem.11

This Project is brought to you for free and open access. It has been accepted for inclusion in Master of Environmental Management Project Reports by an authorized administrator of PDXScholar. Please contact us if we can make this document more accessible: pdxscholar@pdx.edu. 


\section{Johnson Creek Bacteria TMDL Implementation: Status and Trend Analysis Study}

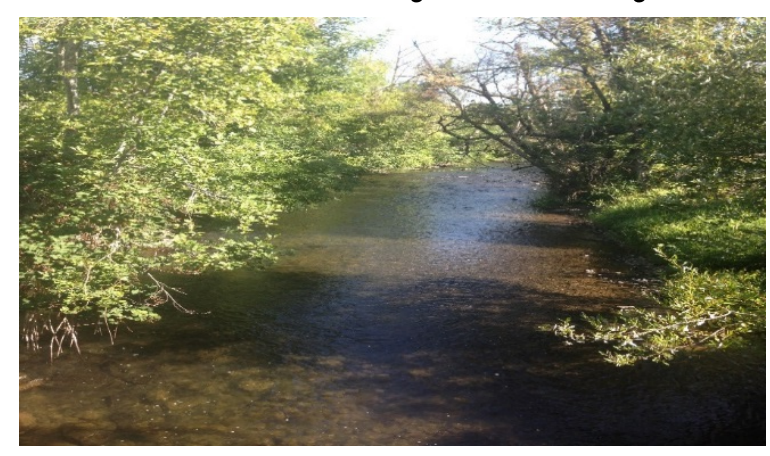

Report prepared by:

John Gala

Portland State University

In partial fulfillment of the requirements for the degree of

Professional Science Masters

In

Environmental Science and Management

Reviewed by:

Joseph Maser, Ph.D., Assistant Professor, Portland State University

Daniel Sobota, Ph.D., Water Quality Analyst, Oregon Department of Environmental Quality Eugene Foster, Ph.D., Manager, Watershed Management, Oregon Department of Environmental Quality
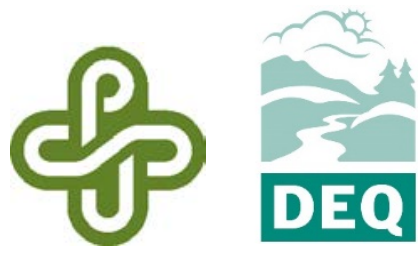


\section{Acronyms}

AgWQMPs Agricultural Water Quality Management Area Plans

BMPs

Best Management Practices

CAFO Confined Animal Feeding Operation

CFU Coliform Forming Unit

COG City of Gresham

COM City of Milwaukie

COG City of Gresham

COE City of Eugene

CCSD\#1 Clackamas County Service District \#1

CSO Combined Sewer Overflow

CWA Clean Water Act

DEQ Department of Environmental Quality

DMAs Designated Management Agencies

EPA Environmental Protection Agency

FPA Forest Practices Act

IJC Inter-Jurisdictional Committee

LA Load Allocation

MOS Margin of Safety

MPN Most Probable Number

MS4 Municipal Separated Storm Sewer

NPDES National Pollutant Discharge Elimination System

OAR Oregon Administrative Rule

ODA Oregon Department of Agriculture

ODEQ Oregon Department of Environmental Quality

ODF Oregon Department of Forestry

PSU Portland State University

SSO Sanitary Sewer Overflow

SWCD Soil Water Conservation District

SWMP Storm Water Management Plan

TMDLs Total Maximum Daily Loads

UIC Underground Injection Control Unit

WQMPs Water Quality Management Plans

WWTP Waste Water Treatment Plant 


\section{Table of Contents}

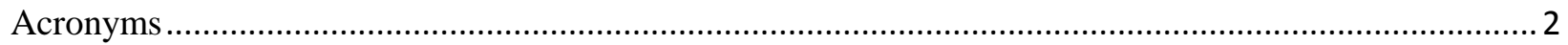

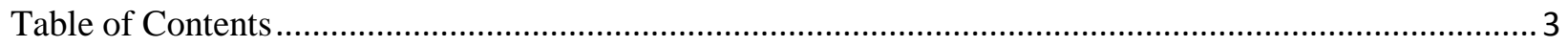

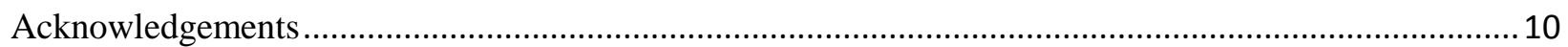

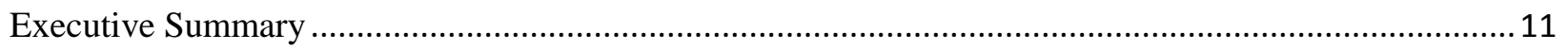

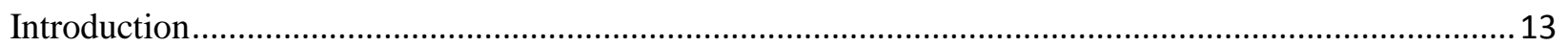

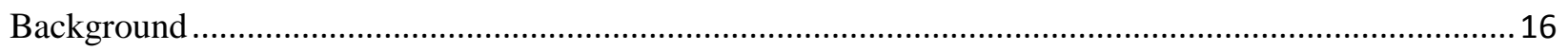

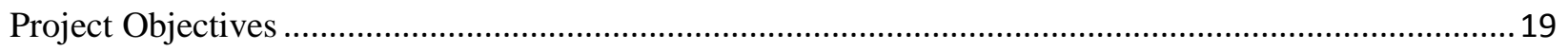

Watershed History and Characteristics ….......................................................................................... 20

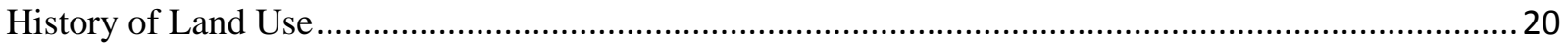

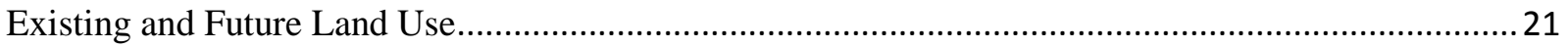

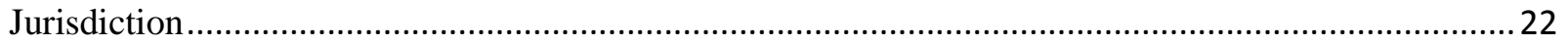

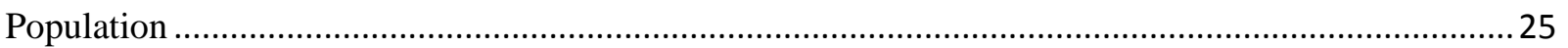

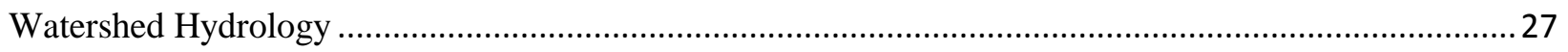

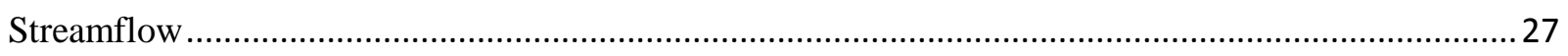

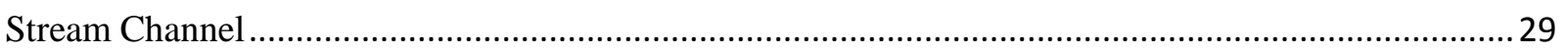

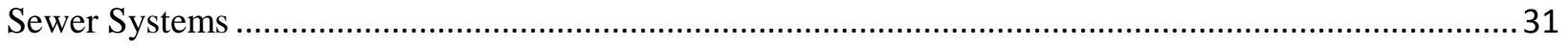

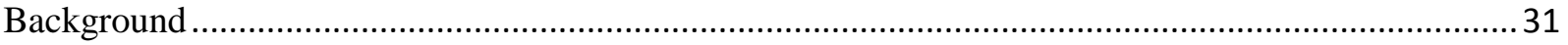

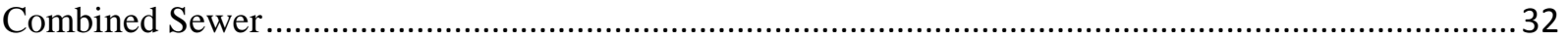

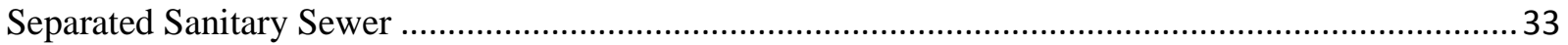

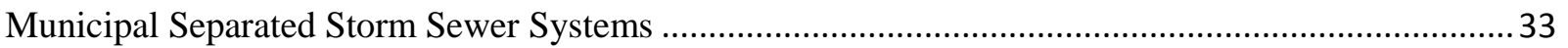

Designated Management Agencies, MS4 Permit \& TMDL …............................................................. 36

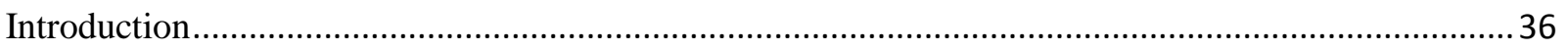

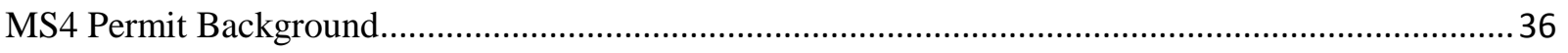

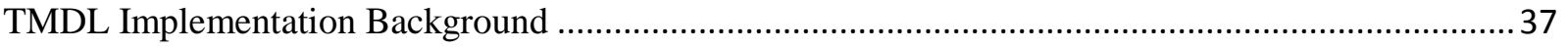

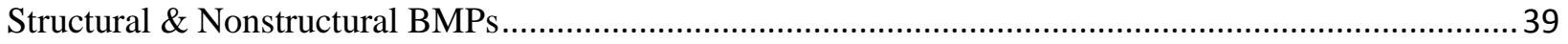

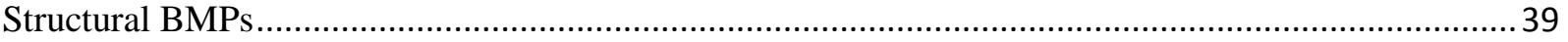

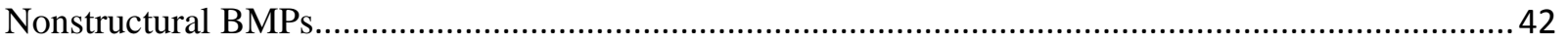

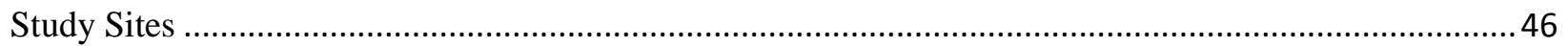

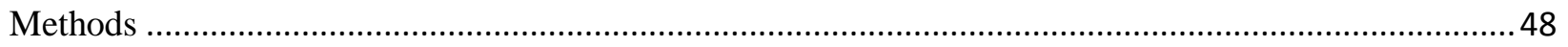

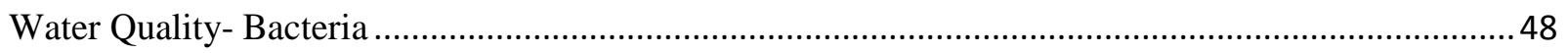

Water Quality Data Preparation ............................................................................................ 48

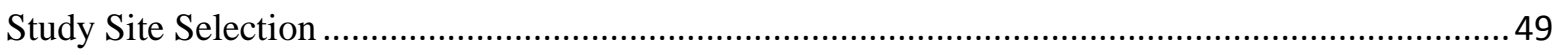

3|Page Final Report: October 23,2017 


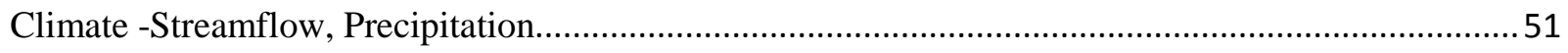

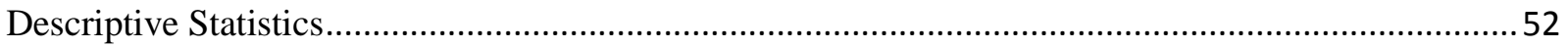

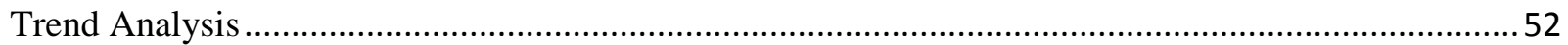

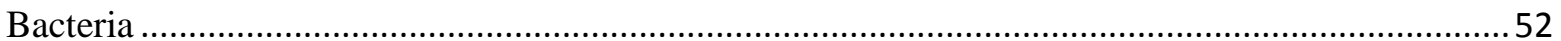

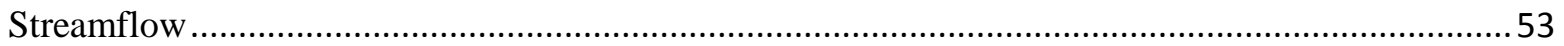

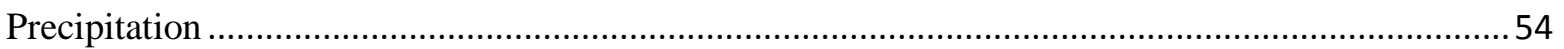

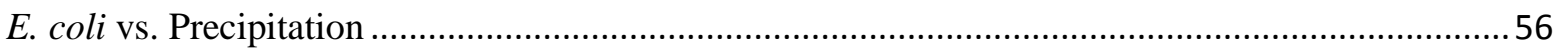

Stream Network/ Sub-Watershed Delineation .........................................................................5

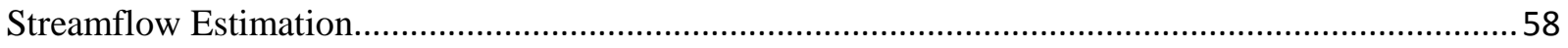

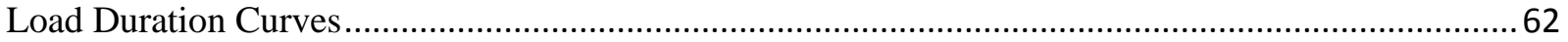

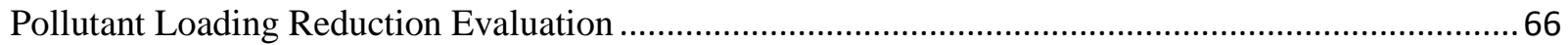

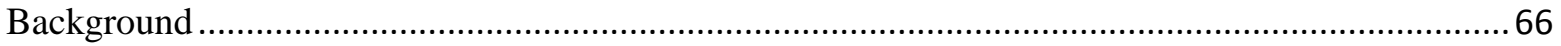

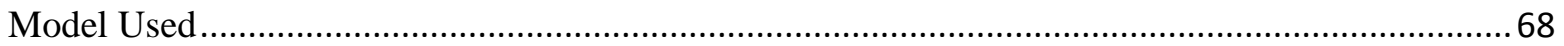

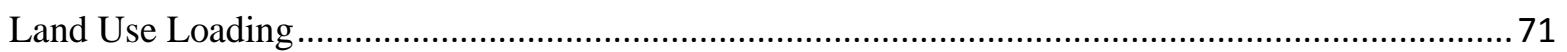

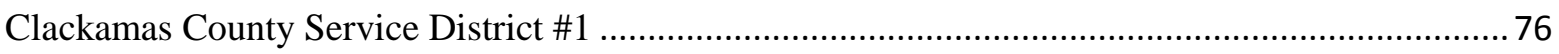

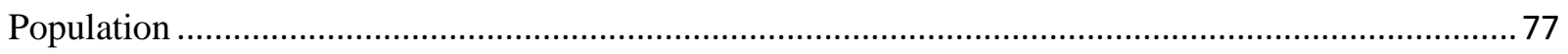

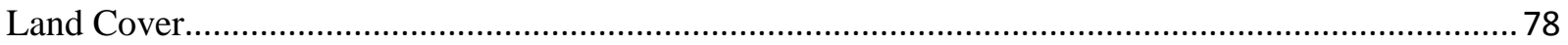

Designated Management Agency Implementation …............................................................................. 79

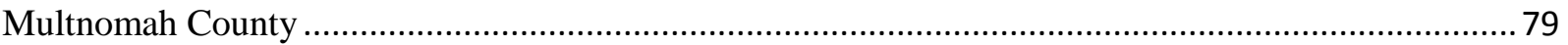

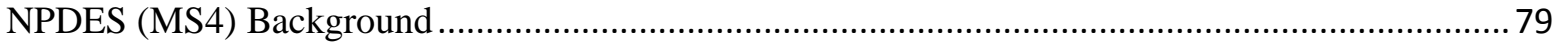

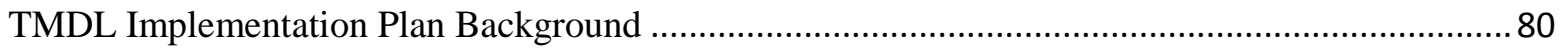

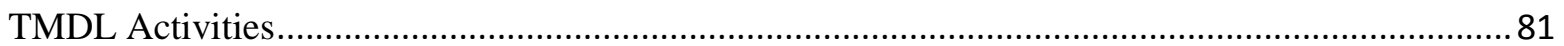

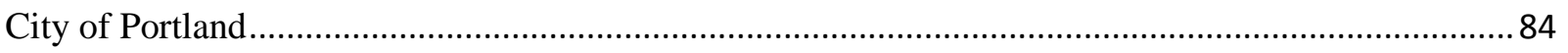

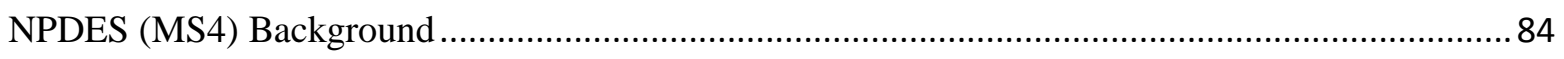

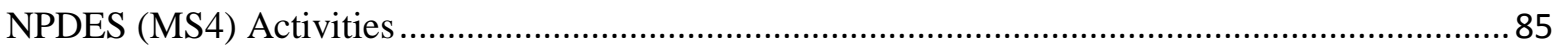

TMDL Implementation Plan Background …................................................................................ 92

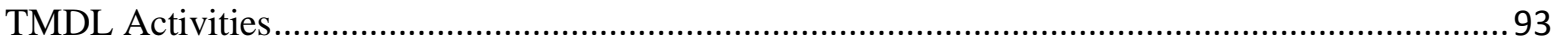

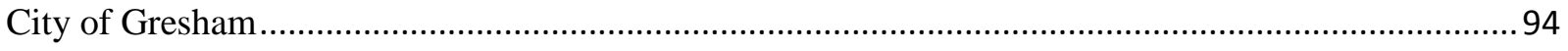

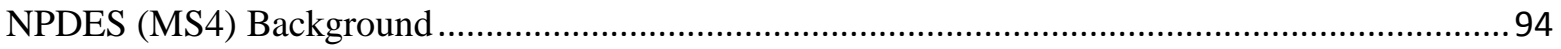

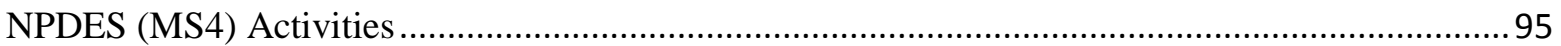

TMDL Implementation Plan Background ........................................................................... 100

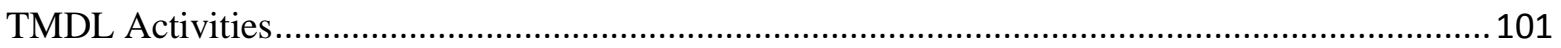

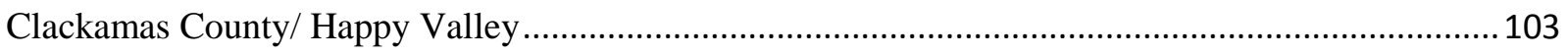

4|Page Final Report: October23,2017 


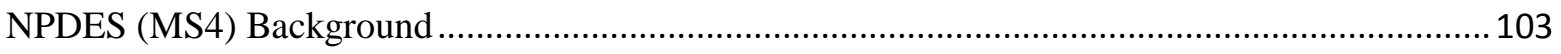

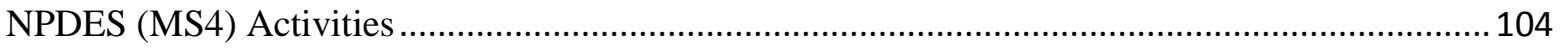

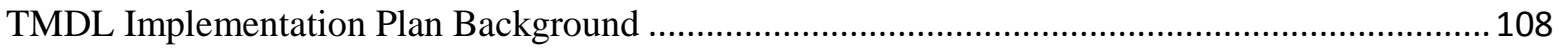

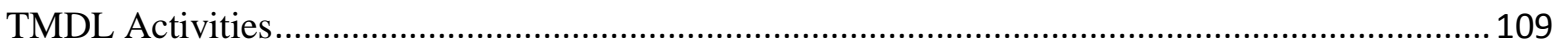

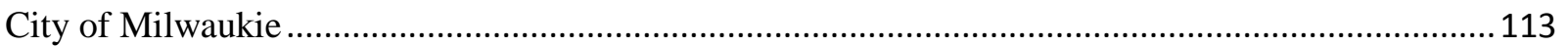

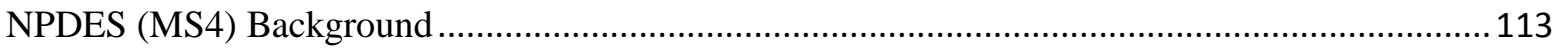

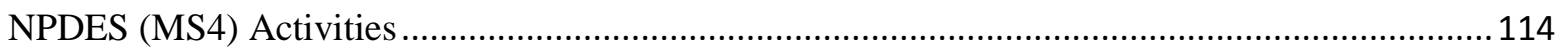

TMDL Implementation Plan Background …...................................................................... 118

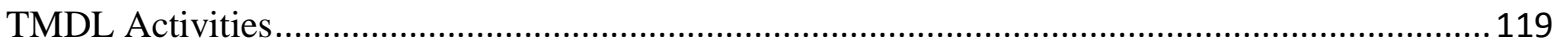

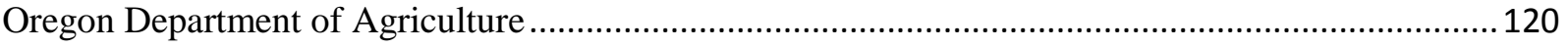

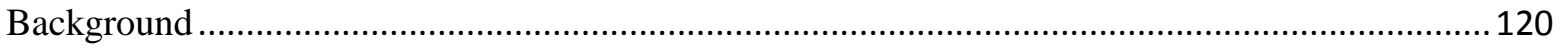

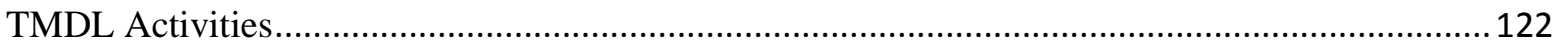

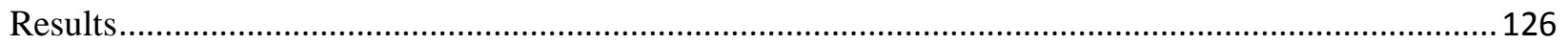

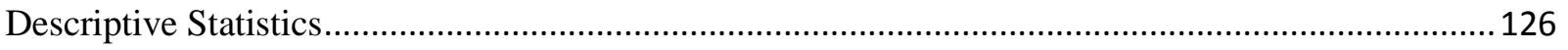

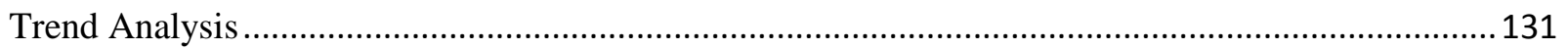

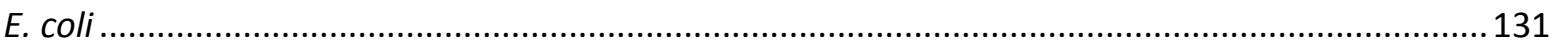

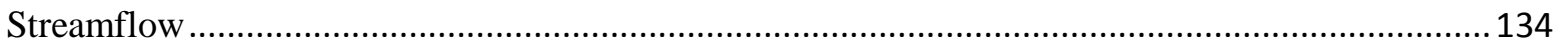

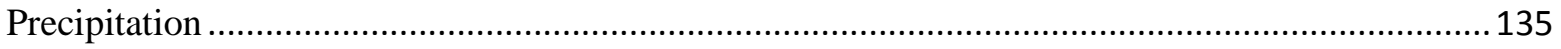

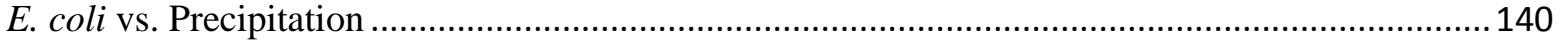

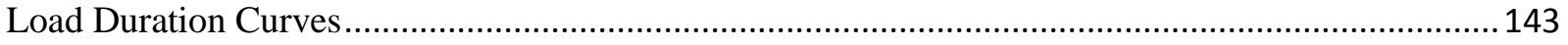

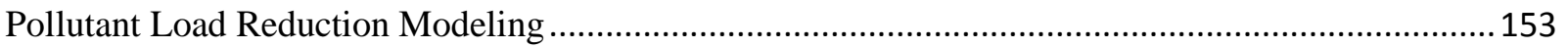

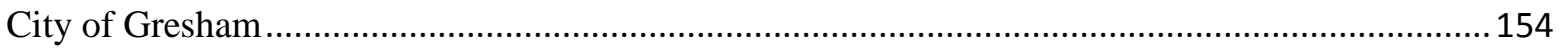

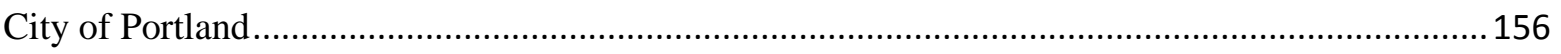

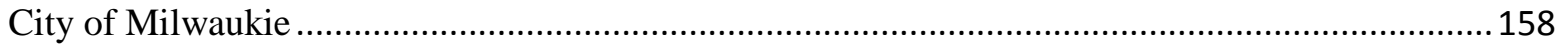

Clackamas County Service District \#1 ….............................................................................. 160

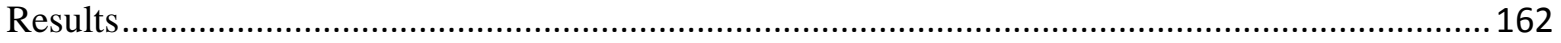

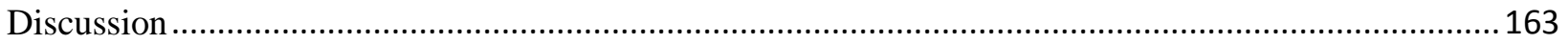

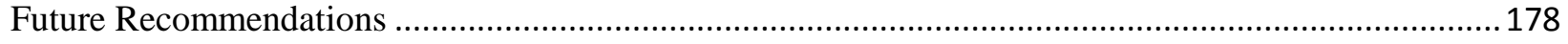

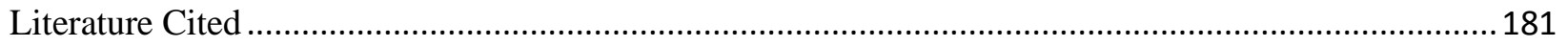

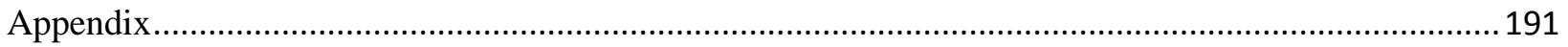




\section{Table of Figures}

Figure 1. Diagram categorizing major E. coli sources, transport vectors, and contributing climate factors. Major potential sources of E. coli were divided into natural and anthropogenic categories, and the latter was further divided

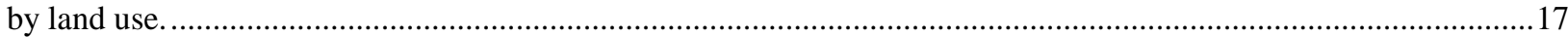

Figure 2. NLCD 2011 land use within the Johnson Creek Watershed (See Methods) ..............................................21 Figure 3. Jurisdictional boundaries within the Johnson Creek Watershed including urban growth boundaries. Figure is from (BES, 2005) 24 Figure 4. Study sites, rain gauges, and flow gauges in Johnson Creek. Study sites, rain gauges, and flow gauges are represented by diamonds, circles, and triangles respectively.

Figure 5. Map of subwatersheds and flow gauges in Johnson Creek used to approximate streamflow for ungauged sites.

Figure 6. Conceptual flow diagram illustrating process used for GIS pollutant load reduction model based off of the EPA Simple Method. . .70

Figure 7. Multnomah County Johnson Creek MS4 boundaries. The entirety of the MS4s owned and operated by Multnomah County within the watershed fall within the City of Portland (Multnomah County, 2014)....................79 Figure 8. Boxplot displaying E. coli $406 \mathrm{cfu} / 100 \mathrm{~mL}$ standard exceedances overtime for Palmblad Rd.................126 Figure 9. Boxplot displaying E. coli $406 \mathrm{cfu} / 100 \mathrm{~mL}$ standard exceedances overtime for Jenne Rd. One outlier in 2003 is not shown in graph, concentration was approximately 24,000 cfu. .........................................................127 Figure 10. Boxplot displaying E. coli $406 \mathrm{cfu} / 100 \mathrm{~mL}$ standard exceedances overtime for SE $158^{\text {th }}$ Ave. One outlier in 2009 is not shown in graph, concentration was approximately 20,000 cfu. ......................................................127 Figure 11. Boxplot displaying E. coli $406 \mathrm{cfu} / 100 \mathrm{~mL}$ standard exceedances overtime for SE $17^{\text {th }}$ Ave. ...............128 Figure 12. Seasonal Kendall trend analysis of E. coli time series data from 1999-2016 for Palmblad Rd. Blue line represents the median fitted line, red dots represent data that exceed the 406 single sample standard, black dots meet the 406 single sample standard, and the dashed line represents the 406 single sample standard.

Figure 13. Seasonal Kendall trend analysis of E. coli time series data from 1999-2016 for Jenne Rd. Blue line represents the median fitted line, red dots represent data that exceed the 406 single sample standard, black dots meet the 406 single sample standard, and the dashed line represents the 406 single sample standard. Figure 14. Seasonal Kendall trend analysis of E. coli time series data from 1996-2015 for SE $158^{\text {th }}$ Ave. Blue line represents the median fitted line, red dots represent data that exceed the 406 single sample standard, black dots meet the 406 single sample standard, and the dashed line represents the 406 single sample standard. 132 Figure 15. Seasonal Kendall trend analysis of E. coli time series data from 1996-2016 for SE $17^{\text {th }}$ Ave. Blue line represents the median fitted line, red dots represent data that exceed the 406 single sample standard, black dots meet the 406 single sample standard, and the dashed line represents the 406 single sample standard. 133 Figure 16. Time series plot of $90^{\text {th }}$ and $100^{\text {th }}$ percentile precipitation events at Cottrell School rain gauge for water years (Oct 1- Sept 30) 1996-2016.

Figure 17. Time series plot of $90^{\text {th }}$ and $100^{\text {th }}$ percentile precipitation events at Gresham Fire Dept. rain gauge for water years (Oct 1- Sept 30) 1996-2016......

Figure 18. Time series plot of $90^{\text {th }}$ and $100^{\text {th }}$ percentile precipitation events at Harney rain gauge for water years (Oct 1- Sept 30) 1996-2016.

Figure 19. Fitted regression line for log base 10 transformed E. coli data from Palmblad Ave vs. cumulative precipitation from storm events prior to collection of grab samples for each sampling date.

Figure 20. Fitted regression line for log base 10 transformed E. coli data from Jenne Rd. vs. cumulative precipitation from storm events prior to collection of grab samples for each sampling date. One outlier (24,000 cfu/100 mL, 0 in precip) exceeded the plot range and was removed.

Figure 21. Fitted regression line for log base 10 transformed E. coli data from SE 158th Ave vs. cumulative precipitation from storm events prior to collection of grab samples for each sampling date. Two outliers (10,000 and $20,000 \mathrm{cfu} / 100 \mathrm{~mL}$, both had 0 inches precipitation) exceeded plot range and were omitted. 141 Figure 22. Fitted regression line for log base 10 transformed E. coli data from SE 17th Ave vs. cumulative precipitation from storm events prior to collection of grab samples for each sampling date.

Figure 23. Load Duration Curve displaying event loads at Palmblad Ave before TMDL Implementation (19992006). Flow categories consist of the following intervals: 0-10\% for High Flows, 10-40\% for Transitional Flows, 
40-60\% for Typical Flows, 60-90\% for Dry Flows, and 90-100\% for Low Flows. Boxplots show the spread and median load for each of the 5 flow intervals.

Figure 24. Load Duration Curve displaying event loads at Palmblad Ave after TMDL Implementation (2009-2016). Flow categories consist of the following intervals: $0-10 \%$ for High Flows, $10-40 \%$ for Transitional Flows, $40-60 \%$ for Typical Flows, $60-90 \%$ for Dry Flows, and $90-100 \%$ for Low Flows. Boxplots show the spread and median load for each of the 5 flow intervals.

Figure 25. Load Duration Curve displaying event loads at Jenne Road before TMDL Implementation (1999-2006). Flow categories consist of the following intervals: $0-10 \%$ for High Flows, $10-40 \%$ for Transitional Flows, $40-60 \%$ for Typical Flows, $60-90 \%$ for Dry Flows, and $90-100 \%$ for Low Flows. Boxplots show the spread and median load

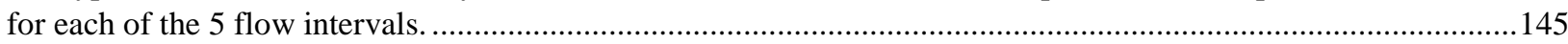
Figure 26. Load Duration Curve displaying event loads at Jenne Road after TMDL Implementation (2009-2016). Flow categories consist of the following intervals: 0-10\% for High Flows, 10-40\% for Transitional Flows, 40-60\% for Typical Flows, $60-90 \%$ for Dry Flows, and $90-100 \%$ for Low Flows. Boxplots show the spread and median load for each of the 5 flow intervals.

Figure 27. Load Duration Curve displaying event loads at SE 158th Ave before TMDL Implementation (19962006). Flow categories consist of the following intervals: 0-10\% for High Flows, $10-40 \%$ for Transitional Flows, 40-60\% for Typical Flows, 60-90\% for Dry Flows, and 90-100\% for Low Flows. Boxplots show the spread and median load for each of the 5 flow intervals.

Figure 28. Load Duration Curve displaying event loads at SE 158th Ave after TMDL Implementation (2009-2015). Flow categories consist of the following intervals: 0-10\% for High Flows, $10-40 \%$ for Transitional Flows, $40-60 \%$ for Typical Flows, $60-90 \%$ for Dry Flows, and $90-100 \%$ for Low Flows. Boxplots show the spread and median load for each of the 5 flow intervals.

Figure 29. Load Duration Curve displaying event loads at SE $17^{\text {th }}$ Ave before TMDL Implementation (1996-2006). Flow categories consist of the following intervals: 0-10\% for High Flows, 10-40\% for Transitional Flows, $40-60 \%$ for Typical Flows, $60-90 \%$ for Dry Flows, and $90-100 \%$ for Low Flows. Boxplots show the spread and median load for each of the 5 flow intervals.

Figure 30. Load Duration Curve displaying event loads at SE $17^{\text {th }}$ Ave after TMDL Implementation (2009-2016). Flow categories consist of the following intervals: 0-10\% for High Flows, 10-40\% for Transitional Flows, 40-60\% for Typical Flows, $60-90 \%$ for Dry Flows, and $90-100 \%$ for Low Flows. Boxplots show the spread and median load

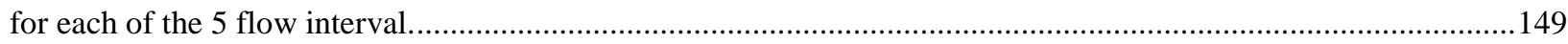
Figure 31. Map of zoning categories and treated areas for Gresham MS4 boundary within Johnson Creek. ............154 Figure 32. Map of zoning categories and treated areas for Portland MS4 boundary within Johnson Creek. .............156 Figure 33. Map of zoning categories and treated areas for Milwaukie MS4 boundary within Johnson Creek. ........158 Figure 34. Map of zoning categories and treated areas for CCSD\#1 MS4 boundary within Johnson Creek (WES 2015)...... ..160

Figure 35. Incremental watershed regions for each of the four study sites including treated areas (MS4 only, includes UIC) and overall changes (126 cfu/ $100 \mathrm{~mL}$ standard) in loading following the implementation of TMDL actions.

Figure 36. Time series plot of $0^{\text {th }}$ and $10^{\text {th }}$ percentile discharge events at Palmblad Road for water years (Oct 1- Sept 30) $1996-2016$. 191

Figure 37. Time series plot of $30^{\text {th }}$ and $70^{\text {th }}$ percentile discharge events at Palmblad Road for water years (Oct 1Sept 30) 1996-2016.

Figure 38. Time series plot of $90^{\text {th }}$ and $100^{\text {th }}$ percentile discharge events at Palmblad Road for water years (Oct 1Sept 30) 1996-2016.

Figure 39. Time series plot of $0^{\text {th }}$ and $10^{\text {th }}$ percentile discharge events at Sycamore gauge for water years (Oct 1Sept 30) 1996-2016.

Figure 40. Time series plot of $30^{\text {th }}$ and $70^{\text {th }}$ percentile discharge events at Sycamore gauge for water years (Oct 1Sept 30) 1996-2016.

Figure 41. Time series plot of $90^{\text {th }}$ and $100^{\text {th }}$ percentile discharge events at Sycamore gauge for water years (Oct 1Sept 30) 1996-2016.

Figure 42. Time series plot of $0^{\text {th }}$ and $10^{\text {th }}$ percentile discharge events at Millport Rd. gauge for water years (Oct 1Sept 30) 1996-2016. 
Figure 43. Time series plot of $30^{\text {th }}$ and $70^{\text {th }}$ percentile discharge events at Millport Rd. gauge for water years (Oct 1Sept 30) 1996-2016. 195 Figure 44. Time series plot of $90^{\text {th }}$ and $100^{\text {th }}$ percentile discharge events at Millport Rd. gauge for water years (Oct

\section{Table of Tables}

Table 1. Relative importance of E. coli loading sources during different flow regimes...........................................15

Table 2. Land use changes for zoned areas within the Johnson Creek Watershed ......................................................22

Table 3. Jurisdictional areas for designated management agencies within the Johnson Creek Watershed. .................24

Table 4. Census data by jurisdictional boundaries within the Johnson Creek Watershed. ..........................................26

Table 5. Gauged and ungauged streamflow statistics for study sites within Johnson Creek. .....................................29

Table 6. Low Impact Development and proprietary structural BMPs ......................................................................42

Table 7. Common Nonstructural BMPs for Urban Stormwater Run-off................................................................45

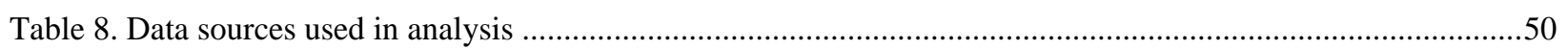

Table 9. Subwatershed areas, gauges and example precipitation values used for approximating streamflow at

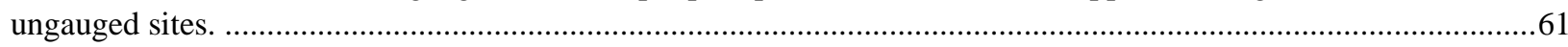

Table 10. Calculating the TMDL by flow regime ……….................................................................................65

Table 11. Land use event mean runoff concentrations for E. coli used in EPA Simple Method GIS model................72

Table 12. Flow reduction and removal efficiency values for structural bmp categories used in GIS model...............72

Table 13. Summary of Multnomah County TMDL Implementation 5 year review (2009-2013) ...............................81

Table 14. Summary of Multnomah County TMDL Implementation for 2015 and 2016. Multnomah County's TMDL

Implementation Plan was updated in 2014 as a part of the 2009-2013 review process............................................83

Table 15. Summary of BMPs implemented by COP in their 2005-2010 NPDES permit cycle and 2011-2016 permit

cycle addressing potential sources of bacterial discharge to JC. ..............................................................................85

Table 16. Summary of major TMDL projects implemented by City of Portland within Johnson Creek. ...................93

Table 17. Summary of annual BMP implementation progress to address bacterial discharge to JC by COG for the years 2006-2016. Data was collected from MS4 annual reports from Gresham's 2005-2010 permit cycle, 2010-2015 permit cycle, and includes implementation activities for 2015-2016. *Note: these years cover two different SWMPs

and as such, do not have identical reporting requirements for all BMPs across years. .............................................95

Table 18. Summary of restoration projects implemented within Johnson Creek or Tributaries by City of Gresham .99

Table 19. Summary of BMPs outlined in COG 2008 TMDL Implementation Plan, 2014 plan reduces BMPs to NPB-

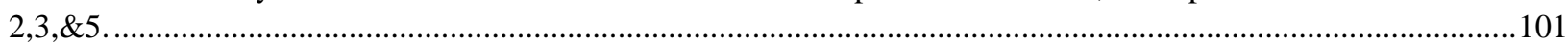

Table 20. Summary of annual BMP implementation progress for CCSD\#1 from 2010-2016................................104

Table 21. Annual progress of BMPs addressed in CCSD\#1 TMDL Implementation Plan to reduce E. coli loading.

Data collected from CCSD\#1 2013-2016 TMDL annual reports. ...........................................................................109

Table 22. Summary of BMPs implemented by COM from 2005-2016 as part of their NPDES stormwater

management program to address potential sources of bacterial discharge to Johnson Creek...................................114

Table 23. Summary of annual progress of TMDL activities for City of Milwaukie for 2009-2011. Following 2011 no

TMDL projects/activities addressing bacteria were reported. .............................................................................119

Table 24. Summary of major implementation activities for Lower Willamette conducted by ODA and local SWCDs reported in biennial reports for 2003-2006, 2007-2009, 2009-2011, 2013-2015, and 2015-2017............................122

Table 25. Mann Kendall results for time series data for $90^{\text {th }}$ and $100^{\text {th }}$ percentile precipitation events at Cottrell

School rain gauge for water years (Oct 1- Sept 30) 1996-2016 ..............................................................................135

Table 26. Mann Kendall results for time series data for $90^{\text {th }}$ and $100^{\text {th }}$ percentile precipitation events at Gresham Fire

Dept. rain gauge for water years (Oct 1- Sept 30) 1996-2016...............................................................................136

Table 27. Mann Kendall results for time series data for $90^{\text {th }}$ and $100^{\text {th }}$ percentile precipitation events at Harney rain

gauge for water years (Oct 1- Sept 30) 1996-2016..............................................................................................137

Table 28. Johnson Creek at Palmblad Ave (Before TMDL) ................................................................................144

Table 29. Johnson Creek at Palmblad Ave (After TMDL) ...................................................................................144

Table 30. Johnson Creek at Jenne Rd (Before TMDL) .........................................................................................146

8|Page Final Report: October 23, 2017 
Table 31. Johnson Creek at Jenne Rd (After TMDL)

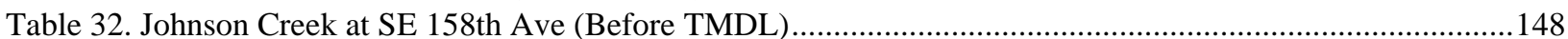

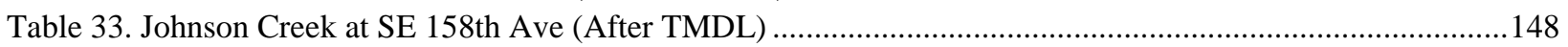

Table 34. Johnson Creek at SE 17th Ave (Before TMDL) ..............................................................................150

Table 35. Johnson Creek at SE 17th Ave (After TMDL) ...........................................................................150

Table 36. Structural BMPs used in Pollutant Load Reduction models, acreage listed for each BMP type as well as installation dates may or may not reflect actual allotment or first and last implementation date due to delineation difficulties and gaps in data.

Table 37. COG impervious surface percentages and runoff coefficients by land use for estimating 2015 bacterial loading. Land use/Land cover data presented is from 2008.

Table 38. Land use event mean storm concentrations (EMCs) of E. coli utilized by all Oregon Association of Clean Water Agencies (ACWA) which includes the following DMAs within the Johnson Creek watershed: Portland, Gresham, Milwaukie, and Happy Valley......

Table 39. COG 2015 bacterial loading with and without BMPs and the associated \% load reduction from implementation of BMPs.

Table 40. COP MS4 area impervious surface percentages and runoff coefficients by land use for estimating 2015 bacterial loading. Land use/ Land cover data presented is from 2015. 156

Table 41. Land use event mean storm concentrations (EMCs) of E. coli utilized by all Oregon Association of Clean Water Agencies (ACWA) which includes the following DMAs within the Johnson Creek watershed: Portland, Gresham, Milwaukie, and Happy Valley.....

Table 42. COP 2015 bacterial loading with and without BMPs and the associated \% load reduction from implementation of BMPs.

Table 43. COM Impervious surface percentages and runoff coefficients by land use for estimating 2015 bacterial loading. Land use/ Land cover data presented is from 2016....................................................................158

Table 44. COM 2015 bacterial loading with and without BMPs and the associated \% load reduction from implementation of BMPs.

Table 45. Happy Valley Impervious surface percentages and runoff coefficients by land use for estimating 2015 bacterial loading. Land use/ Land cover data presented is from 2016.

Table 46. CCSD\#1 2015 bacterial loading with and without BMPs and the associated \% load reduction from implementation of BMPs.

Table 47. Mann Kendall results for time series data for $0^{\text {th }}, 10^{\text {th }}, 30^{\text {th }}, 70^{\text {th }}, 90^{\text {th }}$, and $100^{\text {th }}$ percentile discharge events at Palmblad Road for water years (Oct 1- Sept 30) 1996-2016.

Table 48. Mann Kendall results for time series data for $0^{\text {th }}, 10^{\text {th }}, 30^{\text {th }}, 70^{\text {th }}, 90^{\text {th }}$, and $100^{\text {th }}$ percentile discharge events at Sycamore Gauge for water years (Oct 1- Sept 30) 1996-2016.

Table 49. Mann Kendall results for time series data for $0^{\text {th }}, 10^{\text {th }}, 30^{\text {th }}, 70^{\text {th }}, 90^{\text {th }}$, and $100^{\text {th }}$ percentile discharge events at Millport Rd. Gauge for water years (Oct 1- Sept 30) 1996-2016. 196 


\section{Acknowledgements}

First and foremost I would like to extend my deepest gratitude to my advisor Dr. Joseph Maser for his numerous contributions to this project, his support, and for always taking time out of his busy schedule to assist me. I would like to also thank my other committee members Dr. Daniel Sobota and Dr. Eugene Foster for their assistance towards the completion of this project, including but not limited to, editing and technical support. Special thanks to Torrey Lindbo, Katie Holzer, and the Johnson Creek Watershed Council for supplying a substantial portion of the data used in this project, for promptly responding to data and information requests, and for continually providing constructive feedback throughout this project. Funding for this project was provided by an intergovernmental agreement between ODEQ (US EPA 310 Grant) and Portland State University. Finally, I would like to thank my family and friends for their love and support that helped me through these challenging times. 


\section{Executive Summary}

Like many other waterbodies in the United States, Johnson Creek, a tributary of the Lower Willamette River is water quality limited for bacteria. Escherichia coli (E. coli), a member of the fecal coliform bacteria group, has been found to have a high association with human pathogens and the occurrences of gastrointestinal illnesses in waters used for contact recreation; E. coli is commonly used as an indicator of fecal contamination. In the State of Oregon water contact recreational standards for fecal exposure is assessed by measuring in stream levels of $E$. coli. Because Johnson Creek is water quality limited for bacteria the Oregon Department of Environmental Quality (ODEQ) developed a Total Maximum Daily Load (TMDL) document to address the re-attainment of water quality standards. ODEQ designated management agencies (DMAs) within the Johnson Creek Watershed to adopt best management practices (BMPs) to meet required bacterial loading conditions called for by the TMDL. In this study the status and trends of $E$. coli over the last two decades were assessed (1996-2016) by analyzing loading conditions for different flow regimes before and after implementation of the TMDL. In addition, management actions utilized by DMAs within the watershed were observed, the effectiveness of structural BMPs were assessed, and recommendations were made to better evaluate progress towards meeting the TMDL.

Four sampling sites were selected in this study to evaluate bacterial water quality within the watershed. The study sites spanned from the upper watershed near where Johnson Creek enters the City of Gresham to the mouth of the watershed in the City of Milwaukie. Two of the four study sites, located in subwatersheds dominated by urban development, showed progress towards meeting water quality standards, while the other two sites, which were in subwatersheds where rural and agricultural land use predominated, did not show progress. The strength of the 
conclusions in this study were hampered by inconsistent temporal spacing and sparse data which rendered trend and loading analyses largely un-interpretable. 


\section{Introduction}

Most water quality standard violations in the US result from fecal contamination (Harmel et al. 2010). Contact with fecal contaminated water may result in outbreaks of skin rashes, gastrointestinal illnesses, and exposure to dangerous pathogens (Benham et al. 2006). In general, specific fecal bacteria species are used to indicate the presence of pathogens commonly associated with animal and human feces. Common indicator species or groups used to identify fecal contamination include total coliform, fecal coliform, enterococci, and Escherichia coli (E. coli). In order for indicator species or groups to be effective, they should have similar sources, fate and transport, and growth/die off patterns as the pathogens of concern. E. coli has a high association with fecal pathogens and occurrences of gastrointestinal illnesses (Benham et al. 2006), is present in the feces of humans and warm-blooded animals at numbers exceeding those of pathogens, and shows minimal growth in aquatic systems (Elmund et al., 1999). Therefore, E. coli concentrations are typically used as a surrogate measure for fecal contamination to assess water quality standards in the U.S (Benham et al. 2006).

Until 2017, the recreational contact water quality standard for E. coli in Oregon was a 30 day geometric mean of 126 organisms per $100 \mathrm{~mL}$, consisting of at least 5 samples, and a single sample maximum of 406 organisms per $100 \mathrm{~mL}$ (ODEQ, 2006). The geometric mean standard is currently under revision to be expanded to a 90 day collection period with a minimum of at least 5 samples. The revision to adopt a 90 day period for evaluation of the E. coli geometric mean water quality standard was approved by the Environmental Quality Commission on August 17, 2016 and will take effect once approved by the Environmental Protection Agency (EPA). 
Oregon Administrative Rule (OAR) 340-041-0009 requires that wastewater treatment plants (WWTP) that are discharging to surface waters meet the recreational contact standard for E. coli (ODEQ, 2006). The 126 geometric mean standard for E. coli was selected based off of epidemiological studies conducted by the EPA, which determined that, on average, 8 out of 1000 swimmers exposed to the indicator species at this level would become ill. To meet effluent limits for E. coli WWTPs are required under Clean Water Act (CWA) section 301 to obtain National Pollution Discharge Elimination System (NPDES) permits and implement treatment technologies that are both economically feasible and efficient (Copeland, 1999). Under section 303(d) of the CWA, water quality of receiving waters in exceedance of federal or state water quality standards despite facilities successfully meeting effluent limitation requires that additional pollutant sources (nonpoint sources) be addressed (Copeland, 1999). Water bodies that exceed state water quality standards are designated under section 303 (d) of the CWA as water quality limited.

In the state of Oregon, the Department of Environmental Quality (DEQ) is the head regulatory agency responsible for designating and placing water quality limited bodies of water on the state section 303 (d) list. OAR 340-042-0040(4)(a) defines a water quality limited water body as one that does not meet one or more criteria of a water quality standard (ODEQ, 2006). Section 303(d) of the CWA mandates that states (such as Oregon) develop total maximum daily loads (TMDLs) to address water quality standard violations for 303 (d) listed water bodies. A TMDL document establishes the maximum daily pollutant load that a water body may receive and still attain water quality standards. Pollutant loads are flow based and are equal to the product of stream discharge, the concentration of the water quality limited pollutant parameter, and a conversion factor. Pollutant loads, rather than concentration, are addressed in TMDL 
documents to identify whether or not parameters are meeting their water quality standard for different flow conditions. The incorporation of flow with loading provides insight on general source categories within the watershed for different flow regimes (Table 1).

Table 1. Relative importance of $E$. coli loading sources during different flow regimes

\begin{tabular}{|l|c|c|c|c|c|}
\hline \multicolumn{1}{|c}{ Contributing Source Area } & \multicolumn{4}{|c|}{ Duration Curve Zone Risk } \\
\cline { 2 - 6 } & High Flow & Transitional & Typical & Dry & Low Flow \\
\hline $\begin{array}{l}\text { Direct Point Source } \\
\text { (pipe discharge etc) }\end{array}$ & Low & Low & Low & Medium & High \\
\hline $\begin{array}{l}\text { Stormwater: Impervious runoff/ } \\
\text { MS4 }\end{array}$ & High & High & High & Low & Low \\
\hline $\begin{array}{l}\text { Stormwater: Upland Area } \\
\text { Direct Delivery (livestock in-stream, } \\
\text { wildlife, pets, illegal dumping) }\end{array}$ & High & High & Medium & Low & Low \\
\hline $\begin{array}{l}\text { Agricultural overland flow/Bank } \\
\text { erosion }\end{array}$ & High & Low & Medium & High & High \\
\hline $\begin{array}{l}\text { Failing Septic System } \\
\text { Fyyyyn}\end{array}$ & Low & Low & Medium & High & High \\
\hline
\end{tabular}

Figure adapted from (USEPA, Bruce Cleland, and Oregon Dept. of Environmental Quality 


\section{Background}

Johnson Creek, a tributary in the Lower Willamette River, was designated as water quality limited for bacteria in 1998. As a result, a TMDL was implemented by DEQ following approval by the EPA in 2006. The TMDL for Johnson Creek was included in chapter 5 of the Willamette Basin Bacteria TMDL which addressed water quality limited watersheds within the Lower Willamette Sub-Basin. The TMDL included both natural and anthropogenic activities as

sources of bacterial loading to the stream (Figure 1). Anthropogenic sources, the primary focus of the TMDL, were divided into urban and rural categories and further divided into point and nonpoint sources.

Potential non-point sources of E. coli loading to Johnson Creek mentioned in the TMDL included failing septic systems, livestock via in stream grazing, hobby farms, and run-off from impervious surfaces not draining to a municipal separated storm sewer system (MS4) (ODEQ, 2006) . Potential point sources of E. coli addressed in the TMDL included raw discharge from sanitary sewers due to either mechanical failure or overflow of the sanitary sewer system, stormwater runoff from roads draining into an MS4, and four confined feeding operations (CAFOs). 


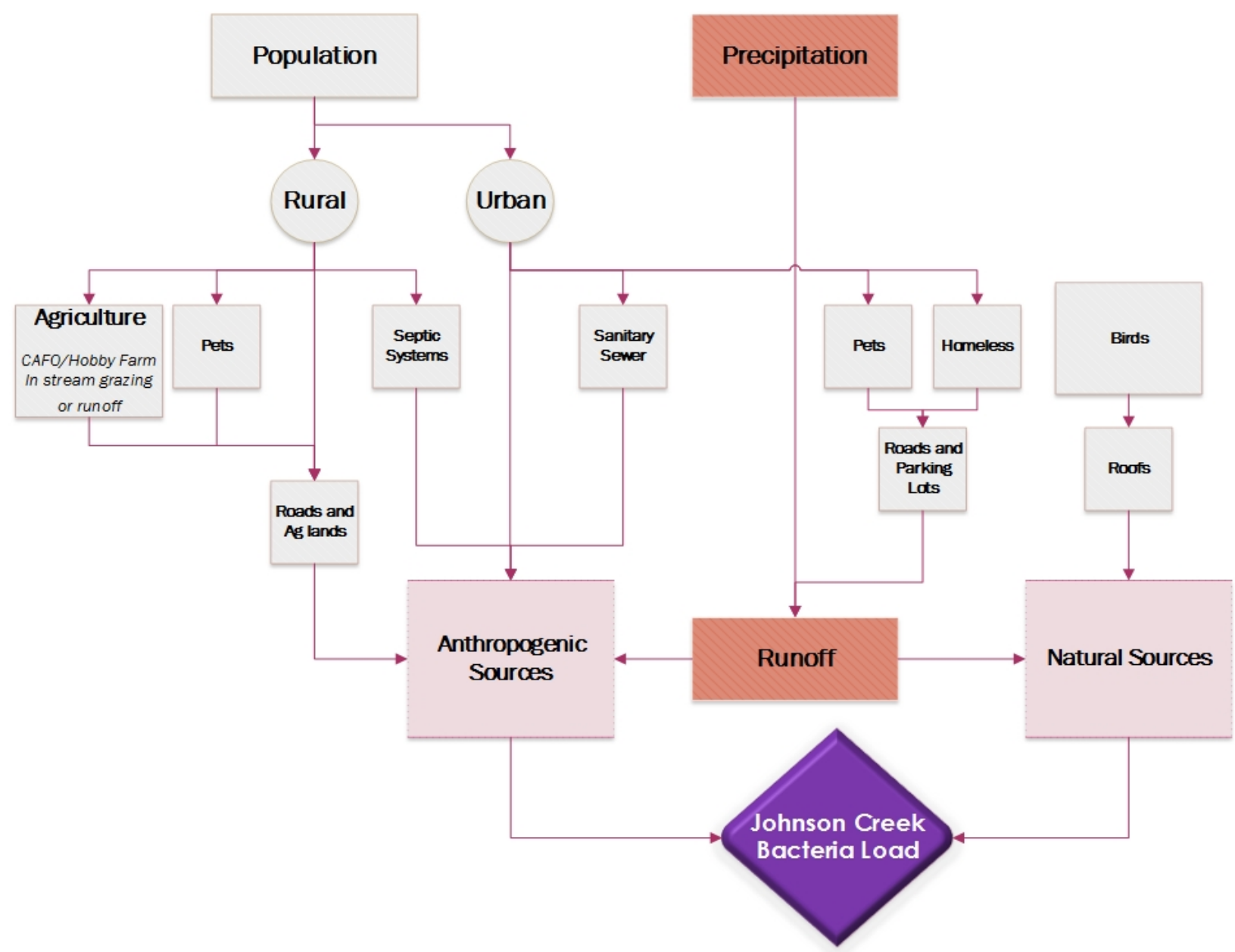

Figure 1. Diagram categorizing major E. coli sources, transport vectors, and contributing climate factors. Major potential sources of E. coli were divided into natural and anthropogenic categories, and the latter was further divided by land use.

DEQ determined that a 78\% E. coli load reduction is needed from both urban and agricultural lands within the watershed to meet state water quality standards. The reduction target for Johnson Creek was established through the use of load duration curves that empirically determine flow-based loading capacities and reductions needed to achieve water quality standards for current bacterial conditions (ODEQ, 2006). To reduce bacterial loading needed to meet state water quality standards the TMDL designated management agencies (DMA) within the watershed that would be responsible for implementing best management practices (BMPs). 
BMPs are pollutant treatment or source control strategies which may generically be categorized as either structural or non-structural. Structural BMPs are pollutant treatment practices that provide a reduction in the volume of a pollutant load, reduce the concentration of a pollutant load, or provide a combination of treatment and volume reduction. Some examples of commonly used structural BMPs includes low impact development (LID) infrastructure such as swales, sand and grass filter strips, porous pavement, retention ponds, detention ponds, ecoroofs, soakage trenches, and raingardens (Clary et al., 2008). Alternatively, non-structural BMPs are source control practices intended to reduce pollutant inputs by either physically removing a source or by changing behaviors of individuals through government regulations and/or voluntary efforts (Schweizer, 2013). These practices include educating pet owners to properly dispose of their pet waste, replacing leaking septic systems, removing roadside waste through citywide street sweeping programs, removing cross connections, and reducing impervious surface coverage (Schweizer, 2013).

In addition to treatment and source control based BMPs, maintenance type BMPs are another important category to consider. Maintenance BMPs are necessary to ensure that storm sewers and structural BMPs operate efficiently. Common stormwater maintenance activities include catch basin cleaning, sewer pipe cleaning, cleaning and upkeep of green infrastructure, and retrofitting stormwater facilities (Field, 2006). A brief history of BMPs implemented by DMAs and their relation to bacterial reductions will be discussed in more detail later on in this document. 


\section{Project Objectives}

This study provides a comprehensive assessment of the status and trends of E. coli within the Johnson Creek Watershed over the last two decades (1995 - 2016). The major objectives of this study were to assess the progress that each DMA has contributed toward the required 78\% $E$. coli load reduction target, to assess the loading/bacterial concentration trends over time for each of the study sites in the watershed, and to identify administrative changes needed to better support the TMDL. This report is intended to help determine if BMPs associated with the TMDL, NPDES Municipal Separate Storm Sewer System Permits (MS4), and non-regulatory actions, are or will be adequate to meet loading reductions required by the Lower Willamette TMDL for E. coli in Johnson Creek. In order for future management strategies to be effective in meeting state water quality standards for E. coli, bacterial sources within the watershed, landscape characteristics, and the relationship between bacteria and climate factors need to be understood. An additional major goal of this study, therefore, was to assess whether or not a reduction in bacterial exceedance events could be observed during wet and dry periods of precipitation or streamflow following the implementation of major projects or strategies used to address characteristic dry or wet bacterial loading sources. 


\section{Watershed History and Characteristics}

\section{History of Land Use}

Johnson Creek is a 25 mile long tributary of the Willamette River that flows through Clackamas and Multnomah Counties and the cities of Gresham, Happy Valley, Portland, and Milwaukie, Oregon. The Johnson Creek watershed is approximately 34,035 acres (Meross, 2000) with a population of around 200,755 as of 2010 (Table 4). The watershed has experienced dramatic landscape changes over the last 160 years. Prior to European settlement in the 1850s, the watershed contained extensive wetlands along the creek and an abundance of forests dominated by Douglas fir (Pseudotsuga menziesii), Western Hemlock (Tsuga heterophylla), and Western Redcedar (Thuja plicata) (BES, 1994). Since the 1850s, development of residential and agricultural land within the watershed has resulted in a loss of forests and wetlands and an increase in impervious surfaces. Urban and agricultural expansion within the watershed began to proliferate following construction of the Springwater Division Line Railroad in 1903, which operated alongside much of Johnson Creek. The railroad shipped farm produce to Portland markets and attracted passengers with the construction of several destination parks along the service route. The railroad was discontinued in 1958 and the rail corridor was purchased by City of Portland in 1990 and Metro in years following. The historic railroad line now makes up the 21 mile long recreational Spring Water Corridor (BES, 2005). 


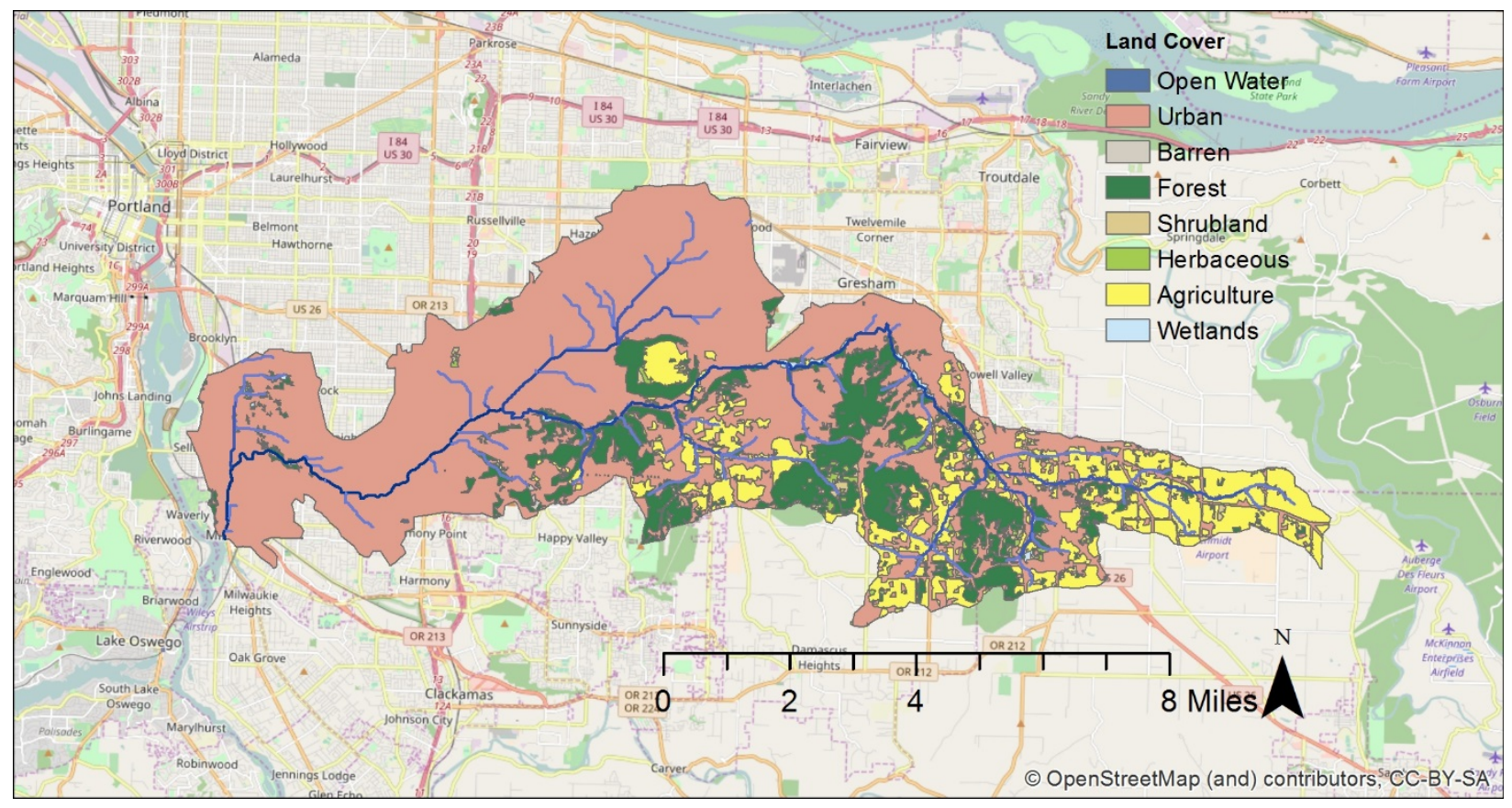

Figure 2. NLCD 2011 land use within the Johnson Creek Watershed (See Methods)

Today the watershed is characterized by mixed land use divided into distinct regions consisting of highly urbanized areas in the lower and middle reaches of the watershed (Cities of Milwaukie, Happy Valley, Portland, and Gresham), agricultural land cover near the headwaters, and fragmented forested and herbaceous regions scattered throughout the middle and upper reaches. As of 2011, National Land Coverage Database (NLCD) shows that the watershed is approximately $67 \%$ urban landscape, $15 \%$ agricultural, $15 \%$ forested, $1 \%$ wetlands, and $2 \%$ other (Figure 2).

In 1990, Oregon Metro published zoning data with more in depth classifications than NLCD data for urban landscapes and more general classifications for vegetative landscapes. Zoning was updated in 1999 to include 26 standard zoning classes and 6 general classes: singlefamily residential, multi-family residential, rural, parks and open spaces, industrial, and 
commercial. Current Metro land use zoning (2016) in the watershed reveals that single-family residential and rural designations make up the largest acreage and percentages at approximately 16,087 acres (47\%) and 9,687 acres (29\%) respectively (Table 2). Multi-family residential and parks and open spaces account for the next largest acreage and percentages at around 3,556 acres (10\%) and 2,175 acres (7\%) respectively. Industrial and commercial land uses make up a small fraction of the watershed with approximately 1,103 (3\%) and 1,428 (4\%) respectively.

As shown in (Table 2) single/multi-family residential, commercial, and parks/open spaces are all projected to increase by 2040, with single-family residential accounting for 19,227 acres (57\%) of the watershed. Conversely, both rural and industrial land use are projected to decline by the year 2040, with rural land use dropping to 2,868 acres (8\%) and industrial land use completely disappearing (Table 2).

Table 2. Land use changes for zoned areas within the Johnson Creek Watershed

\begin{tabular}{|l|l|l|l|l|}
\hline $\begin{array}{l}\text { Zoning Category } \\
\text { Acres (percent) }\end{array}$ & $\mathbf{1 9 9 9}^{\mathbf{2}}$ Acres (\%) & \multicolumn{2}{|l|}{$\begin{array}{l}\text { Current (2016) } \\
\text { Acres (\%) }\end{array}$} & $\begin{array}{l}\text { Future } \\
\mathbf{( \% )}\end{array}$ \\
\hline Single Family Residential & $15,399(45 \%)$ & $16,087 \quad(47 \%)$ & $19,227 \quad(57 \%)$ \\
\hline Multi-Family Residential & $2,930 \quad(9 \%)$ & $3,556 \quad(10 \%)$ & $4,091 \quad(12 \%)$ \\
\hline Rural/Agricultural & $11,175(33 \%)$ & $9,687 \quad(29 \%)$ & $2,868 \quad(8 \%)$ \\
\hline Parks and Open Space & $1,172 \quad(5 \%)$ & $2,175 \quad(7 \%)$ & $4,835 \quad(13 \%)$ \\
\hline Industrial & $1,499 \quad(4 \%)$ & $1,103 \quad(3 \%)$ & 0 & $(0 \%)$ \\
\hline Commercial & $1,261 \quad(4 \%)$ & $1,428 \quad(4 \%)$ & $3,466 \quad(10 \%)$ \\
\hline Total & $34,035 \quad(100 \%)$ & $34,035 \quad(100 \%)$ & $34,035 \quad(100 \%)$ \\
\hline
\end{tabular}

1. Current population for zoning categories within the Johnson Creek Watershed obtained from Metro RLIS data and can be found here: http://rlisdiscovery.oregonmetro.gov/?action=viewDetail\&layerID=416\#

2. 1999 and projected 2040 Metro RLIS population for zoning categories within the Johnson Creek Watershed from (Meross, 2000) 


\section{Jurisdiction}

The Johnson Creek watershed contains six local jurisdictions including Clackamas and Multnomah Counties and the cities of Gresham, Happy Valley, Milwaukie, and Portland. Unincorporated regions within the watershed fall under county jurisdiction while urban areas within the watershed are the responsibility of the cities (BES, 2005). Portland, unincorporated Clackamas County (not including Milwaukie and Happy Valley), and Gresham are responsible for the largest portions of the watershed at 41,24 , and $20 \%$, respectively (Table 3). The jurisdictions that have the smallest land coverages in the watershed includes unincorporated Multnomah County (not including Portland and Gresham), Milwaukie, and Happy Valley (Table 2).

Jurisdictional coverage within the watershed has been subject to slight changes in recent years due to urban growth expansion. To account for population expansion, Metro approved an urban growth boundary (UGB) expansion in 1997 (Meross, 2000). The UGB has been expanded several times over the last decade, most recently in 2010, and has led to the development of 6,000 acres of land within the watershed (JCCP, 2012). As of 2012, the UGB accounted for approximately $72 \%$ of the watershed and is anticipated to continue to increase in subsequent years (JCCP, 2012). Expansion of urban land within the watershed has reduced the jurisdictional area of unincorporated Multnomah County from 11\% in 1997 to 9\% in 2016 and has increased the jurisdictional area of Happy Valley from 0.1\% in 1997 to 2\% in 2016 (BES, 2005) and (Table 3). A map of the current jurisdictional boundaries within the watershed is shown in (Figure 3). 
Table 3. Jurisdictional areas for designated management agencies within the Johnson Creek Watershed.

\begin{tabular}{|l|l|l|}
\hline Jurisdiction & Area in Watershed (Acres) & $\begin{array}{l}\text { Jurisdiction as a Percent of } \\
\text { Watershed }\end{array}$ \\
\hline Portland & 13,791 & $41 \%$ \\
\hline $\begin{array}{l}\text { Unincorporated Clackamas } \\
\text { County }\end{array}$ & 8,207 & $24 \%$ \\
\hline $\begin{array}{l}\text { Gresham } \\
\text { Councorporated Multnomah }\end{array}$ & 6,680 & $20 \%$ \\
\hline $\begin{array}{l}\text { Milwaukie } \\
\text { Happy Valley }\end{array}$ & 1,447 & $9 \%$ \\
\hline Total & 768 & $4 \%$ \\
\hline
\end{tabular}

1. $\quad$ Current (2016) jurisdictional areas within the Johnson Creek Watershed were obtained by clipping the Metro 2016 RLIS zoning layer to the watershed. Both the Johnson Creek Watershed and zoning shapefile can be found here: http://rlisdiscovery.oregonmetro.gov

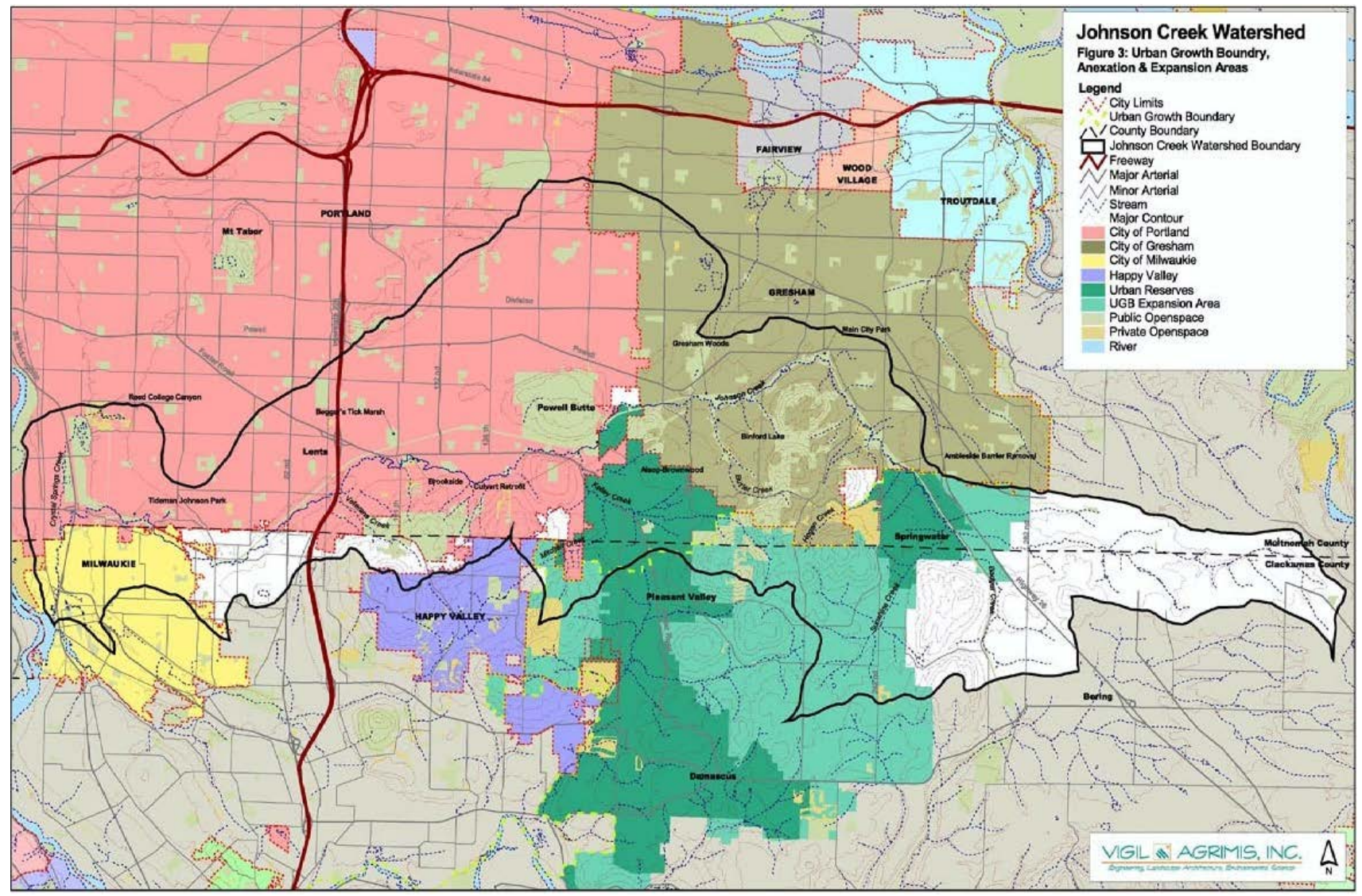

Figure 3. Jurisdictional boundaries within the Johnson Creek Watershed including UGB. Figure is from (BES, 2005) 


\section{Population}

As of 2010, the population within the Johnson Creek watershed was approximately 200,755. Over the last two decades the watershed population has increased by approximately 27\% from 146,144 individuals in 1990 to the 2010 population of 200,755 (Table 4). The city of Happy Valley, Gresham, and Portland displayed the greatest increases in population from 1990 to 2010 with population increases of $79 \%, 47 \%$, and 25\% respectively (Table 4). Multnomah and Clackamas County showed lesser changes in population, with $10 \%$ and $17 \%$ increases in population, while Milwaukie showed a slight decline in population from 1990 to 2000; but virtually no population change overall from 1990 to 2010 (Table 4) . The substantial increase in population within Happy Valley is likely attributed in part to the 1500 acre Pleasant Valley UGB expansion in 1997 (Figure 3) and the inclusion of the Mitchel Creek headwaters region in 2002 into the UGB (BES, 2005). Population within the watershed is anticipated to continue to increase as urban areas expand. The UGB was most recently expanded by Metro in 2010. This expansion designated the headwater region of the watershed near Highway 26 in both Clackamas and Multnomah counties as urban reserves (Figure 3) (JCCP, 2012). 
Table 4. Census data by jurisdictional boundaries within the Johnson Creek Watershed.

\begin{tabular}{|l|l|l|l|}
\hline Jurisdiction & $\mathbf{1 9 9 0}$ Census $^{\mathbf{1}}$ & $\mathbf{2 0 0 0}$ Census $^{2}$ & 2010 Census $^{2}$ \\
\hline Portland & 98,333 & 110,596 & 130,310 \\
\hline $\begin{array}{l}\text { Unincorporated } \\
\text { Clackamas County }\end{array}$ & 14,635 & 16,447 & 17,455 \\
\hline Gresham & 17,975 & 29,267 & 34,236 \\
\hline $\begin{array}{l}\text { Unincorporated } \\
\text { Multnomah County }\end{array}$ & 1,919 & 2,137 & 2,123 \\
\hline Milwaukie & 12,522 & 13,181 & 13,037 \\
\hline Happy Valley & 760 & 2,018 & 3,594 \\
\hline Total & 146,144 & 173,646 & 200,755 \\
\hline
\end{tabular}

1. Census tracts by block (County level) and the associated population data were removed from both American Fact Finder and census.gov, the 1990 census tracts by block and population data are archived and can be found here: https://data2.nhgis.org

2. Census tracts by block (County level) and the associated population data were obtained from: https://www.census.gov/geo/maps-data/data/tiger-line.html and from: https://factfinder.census.gov/faces/nav/jsf/pages/index.xhtml respectively. 


\section{Watershed Hydrology}

\section{Streamflow}

There are three streamflow gauging stations within Johnson Creek operated by the U.S Geological Survey (USGS). The uppermost gauge at the cross section of Regner Road (river mile 16.3) monitors flow for 15.3 square miles of the upper watershed (Headwaters to Springwater community). The Regner gauge is the most recent addition to the stream, it has continuous flow data from February 2, 1998 to the present. Downstream from the Regner gauge is the Sycamore gauge, which has continuous flow data from 1940 to the present. The Sycamore gauge is located approximately at the halfway point of the stream (river mile 10.2) and monitors flow for 26.5 square miles. The final gauge within the stream is the Milport Road gauge located near the SE $17^{\text {th }}$ study site. The Milport gauge offers continuous flow data from April 1989 to the present, and monitors flow for nearly the entire watershed (river mile 0.7) (51.8 square miles).

As can be seen in (Table 5), average and maximum flow events for the selected sites increase monotonically moving downstream from the headwaters to the mouth of the stream. Due to the lack of coverage of flow gauges within the watershed, flow estimates for regions of interest (see Study Sites) were determined (see Methods). Maximum flow events for both gauged and ungauged sites (estimated) typically occur in November, December, January, and February (Malone, 2014) (Table 5). Minimum flow events by contrast, tend to occur in July, August, and September (Malone, 2014) (Table 5). 
Rain and groundwater inflow control flow within the watershed. Peak flow events typically occur in November, December, January, and February (Malone, 2014) in response to rainfall events of 0.5 inches (BES, 2016). Low and dry flow events by contrast are primarily groundwater influenced and typically occur from July to September. Groundwater springs within the watershed are mostly located from river mile 5.5 to the mouth. Due to the higher proportion of groundwater springs within the lower watershed, dry flow events tend to be significantly higher than in the upper watershed (Lee and Snyder, 2009) (Table 5) . Streamflow within the watershed is additionally influenced by tributaries draining to the main stem of the creek. Tributaries draining to Johnson Creek include Crystal Springs, a groundwater fed tributary located at river mile 1.3, Errol Creek located at river mile 1.7, Kelley Creek at river mile 11.4, Butler Creek at river mile 13.8, Hogan Creek at river mile 17.5, and Sunshine Creek at river mile 19.2 (BES, 1994).

The land use/land cover within the watershed influences peak flow events substantially. The permeability of soils and urban areas within the watershed determines the amount of infiltration or runoff that will occur. The watershed is divided into two hydrologic regions. The hydrologic boundary in the watershed is located from $82^{\text {nd }}$ Ave in Portland eastward towards downtown Gresham (BES, 1994). The northern hydrologic region in the watershed consists of porous soils which allows for a high degree of stormwater infiltration, while the southern hydrologic region consists of semi-impermeable clays that do not allow for infiltration, resulting in run off (BES, 1994). Hydrologic characteristics within the watershed can be further described longitudinally. Drains, ditches, and silt loam soils in the eastern portion of the watershed near the headwaters results in high rates of runoff (Lee and Snyder, 2009). The drainage from the Sycamore gauge to the upper watershed is primarily responsible for peak flow events within the watershed. 
The lower portion of the watershed by contrast contributes less to peak flows due to infiltration of stormwater by drywells and combined sewers (Lee and Snyder, 2009) in the northern hydrologic boundary within Portland.

Table 5. Gauged and ungauged streamflow statistics for study sites within Johnson Creek.

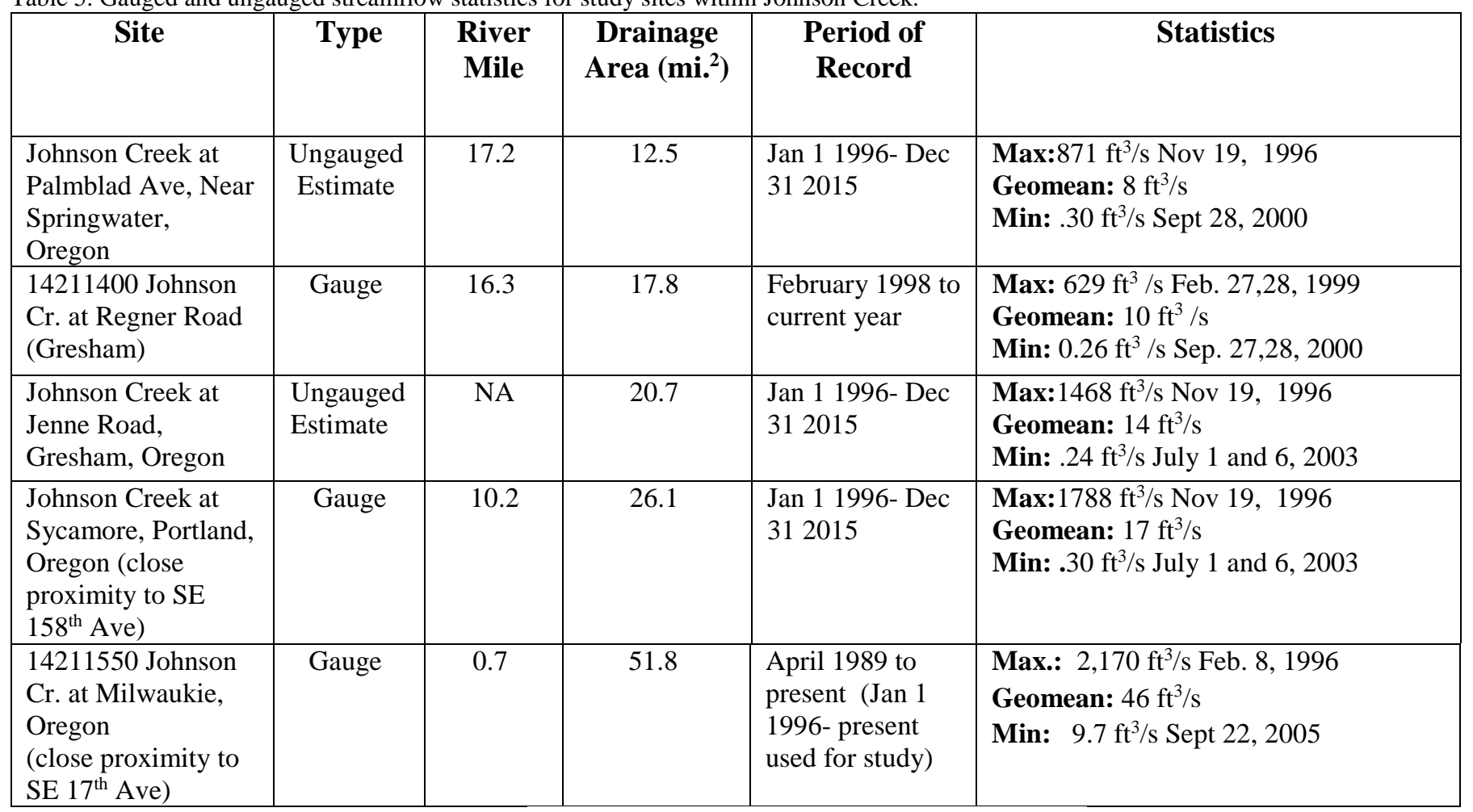

1. Gauged streamflow data from: https://waterdata.usgs.gov/or/nwis/current/?type=flow and (BES, 2005)

2. Streamflow estimate procedures for ungauged sites are described in the methods section of this document

\section{Stream Channel}

Stream channel characteristics with Johnson Creek have been significantly altered within the last century following increases in settlement along the floodplains (BES, 1994). Natural cycles within the watershed tend to result in meandering channels as streambanks are gradually eroded away. These erosional processes in the absence of anthropogenic influence tend to reduce the floodplain but preserve channel morphology. Floodplains are low elevation regions adjacent to a stream that are prone to periodic flooding events. The need to control flooding within the 
watershed led to a major project by the federal Works Progress Administration (WPA) in the 1930's. The project which took place in the lower 11 miles of the creek, from SE $158^{\text {th }}$ to the mouth, excavated the streambed, widened the channel, and armored the stream banks with stone (Lee and Snyder, 2009). Despite the efforts of this project to mitigate flooding, flooding continued. Stream restoration projects funded by City of Portland in recent years (Table 16) have attempted to restore stream channels in the lower 11 miles of the creek to natural conditions. Unfortunately the extent of hydrologic impacts due to the 1930 WPA project are unknown as measurements of streamflow within the creek did not begin until the installation of the Sycamore Gauge in the 1940s (Lee and Snyder, 2009). 


\section{Sewer Systems}

\section{Background}

Pollutant inputs to Johnson Creek are discharged through open channel or through piped systems (BES, 1994). Wastewater is served by municipal sanitary sewers and sent to wastewater treatment facilities in urbanized portions of the watershed or by septic systems in unincorporated areas of the watershed near the headwaters (BES, 1994). Stormwater inputs to Johnson Creek from either municipal separated storm sewer systems (MS4) or from open channel discharge, on the other hand, are treated by green infrastructure treatment facilities (BES, 2005). Septic systems as well as sanitary sewer systems may be a source of bacterial loading if structural or mechanical failure occurs (ODEQ, 2006). Septic or sanitary sewer system failure may result in raw sewage discharge to the stream. For septic systems this typically occurs if the system is not properly maintained and/or if soil permeability is inadequate in the drain field (BES, 1994). Sanitary system failure typically occurs due to a leaking pipe or physical blockage which may cause sanitary sewer overflow (SSO). Sanitary pipes within the watershed are investigated routinely as a part of stormwater management programs by City of Gresham, City of Portland, City of Milwaukie, and Clackamas County, to prevent illicit wastewater discharges to the creak.

Unlike sanitary sewer systems, septic systems are not routinely inspected, and prevention methods have generally relied on educating homeowners to properly maintain their onsite systems. Septic systems are slowly being replaced by connections with centralized sewage systems in the watershed. The Mid-County Sewerage Project conducted in 1992 by Cities of Portland and Gresham, and completed in 2001, significantly reduced the number of septic systems within annexed regions of Multnomah County by requiring homeowners operating 
septic systems to hook up to the municipal sanitary system. Rural watershed regions located within Clackamas County including Happy Valley and the agricultural portion of the upper watershed continue to utilize septic systems. These remaining septic systems are anticipated to be replaced as the watershed continues to expand its urban boundary and connect to the municipal sanitary sewer system.

\section{Combined Sewer}

A combined sewer is a system that conveys both sanitary sewage and stormwater in the same pipes. Combined sewers are an outdated technology found in older cities in the U.S. Within the Johnson Creek Watershed, combined sewers serve approximately $8 \%$ of the watershed, all of which are located within the City of Portland (BES, 2005). These systems were constructed prior to wastewater treatment requirements established by the CWA. During this time, wastewater was discharged to the nearest body of water through outfalls (BES, 1994). In the 1940s, due to extensive pollution in the Willamette River, the City of Portland installed combined sewer interceptors to send both stormwater and wastewater to nearby treatment plants. The loading capacity of combined sewers in Portland is only three times greater than dry-weather wastewater flow. Because of this, light rain events can lead to overflow of the combined sewers, resulting in the discharge of untreated wastewater into nearby bodies of water.

To prevent combined sewer overflows (CSOs), the city has constructed separated sanitary and storm sewer systems and underground injection control units (UIC) as the urban service boundary expands (BES, 1994). Unlike combined sewers and separated sanitary and storm sewers, UICs are an unlikely source of pollution to streams as surface water is injected into aquifers underground. UICs serve approximately 23\% of the watershed, nearly all of which are operated and owned by the City of Portland (BES, 2005). There are no combined sewer outfalls within 
Johnson Creek. However, some combined sewer collection pipes cross the creek and have the potential to be a source of bacterial loading if damaged, not maintained, or have been improperly constructed. The Johnson Creek interceptor sewer, for example, was a potential source of bacterial loading to the creek from the combined sewer system. The interceptor sewer pipe, located at river mile 12.5 along the Gresham City boundary, was constructed with holes in the pipe to prevent surfacing from groundwater pressure. During dry flow events the interceptor pipe had the potential to directly discharge wastewater into the stream (BES, 1994). The interceptor pipe was successfully buried in 2014 to prevent the occurrence of wastewater discharge into the stream (BES, 2014).

\section{Separated Sanitary Sewer}

Separated sanitary sewers are systems that convey wastewater to wastewater treatment plants. Within the watershed, separated sanitary sewers are owned and operated by the Cities of Portland, Gresham, and Milwaukie. Sanitary waste within Portland is conveyed by two pump stations within the watershed to the Columbia Boulevard Wastewater Treatment Plant (BES, 2000). In Gresham, sewage is conveyed to the Gresham Wastewater Treatment Plant. Both Milwaukie and Happy Valley wastewater is conveyed to the Kellogg Creek Water Resource Recovery Facility that is owned and operated by Clackamas County.

\section{Municipal Separated Storm Sewer Systems}

Municipal Separated Storm Sewer Systems (MS4) are conveyance systems used to collect stormwater generated during periods of heavy rain. MS4 systems discharge stormwater and other drainage into nearby streams at sites referred to as stormwater outfalls. Prior to 1987 stormwater collected by an MS4 was not required to be treated and major stormwater dischargers 
were exempted from CWA NPDES permit requirements unless an activity would have an adverse impact on the quality of stormwater (Franzetti, 2005).The passage of the Water Quality Act of 1987 (an amendment to the CWA) established regulatory requirements for stormwater discharges. The act required that municipalities and industries reduce pollution in urban stormwater runoff discharging to MS4s (BES, 1994). More specifically, MS4s in urban areas serving a population of 100,000 or more, and certain industries were required to develop Stormwater Management Plans (SWMP) that outline various BMPs to prevent adverse impacts to streams from the MS4 system to the maximum extent practicable (MEP) (Franzetti, 2005). This standard is based upon a community's ability to finance and implement the SWMP and associated BMPs, technological feasibility, effectiveness, reliability and sustainability ${ }^{1}$. DEQ permits require that BMPs be adaptively managed to ensure performance effectiveness over time. These requirements however, did not take effect until 1990 when the EPA issued the stormwater rule to the 1987 CWA amendment. As such, the Phase I regulated communities developed these SWMPs in 1995. EPA issued another stormwater rule in 1999 extending stormwater regulations to MS4 communities serving less than 100,000 individuals (Franzetti, 2005) and these Phase II communities developed their SWMPs in 2006.

Under the 1990 and 1999 EPA stormwater rule, Phase I and II MS4 communities respectively, were required to obtain an NPDES stormwater permit, develop a stormwater management plan (SWMP) describing BMPs that would be implemented to achieve pollutant reductions and compile and submit to the state or EPA (DEQ in Oregon) an annual report detailing the implementation progress for stormwater management BMPs. NPDES municipal separated stormwater sewer system permits or MS4 permits, were categorized as either general

\footnotetext{
${ }^{1}$ City of Gresham 2005-2009 and 2009-2014 Stormwater Management Plan.

34 |Page Final Report: October23,2017
} 
or individual permits, the latter of which contains more stringent requirements (Franzetti, 2005).

Phase I communities were required to obtain an individual permit due to their high potential to adversely impact stormwater. Individual permits for Phase I communities required 11 BMP categories to reduce pollutant loading to the maximum extent practicable. Phase II communities on the other hand, only required a general permit, and 6 general BMP categories to address pollutant loading reduction (Franzetti, 2005). MS4 permits for both Phase I and II communities once issued are valid for a 5 year duration, after which SWMP revisions are required to obtain a new permit. 


\section{Designated Management Agencies, MS4 Permit \& TMDL}

\section{Introduction}

Designated Management Agencies (DMAs) are government entities identified within the TMDL that have legal authority over sources of water quality pollutants. DMAs within the Johnson Creek Watershed include Multnomah County, Clackamas County, Oregon Department of Agriculture, Oregon Department of Forestry, City of Portland, City of Milwaukie, City of Gresham, and City of Happy Valley. Due to the legal authority that these agencies possess, they are required to manage pollutant sources to the maximum extent possible through usage of BMPs. For point sources bacterial management plans are addressed through a storm water management plan as required by the MS4 NDPES permit. Nonpoint sources, on the other hand, are not subject to any permits but are addressed by a TMDL implementation plan required by ODEQ for any entity (e.g., city, county, and state) believed to be a contributing source (ODEQ, 2006).

\section{MS4 Permit Background}

BMPs used to minimize polluted stormwater discharge from municipal separate storm sewer systems (MS4) are addressed through the National Pollution Elimination System (NPDES) permit process which is required under the CWA and is administered by ODEQ. The MS4 permit requires development of a Storm Water Management Plan (SWMP) and an annual progress report throughout a five year permit cycle. MS4 permits are applicable to separated storm sewers and are not required for municipalities in rural areas serving less than 10,000 individuals (Franzetti, 2005). All agencies within the watershed with the exception of ODA and ODF are responsible for managing stormwater. However, City of Portland, City of Gresham, and 
Clackamas County are the lead agencies responsible for implementing stormwater management programs and obtaining MS4 permits. Co-Permittees in the watershed consists of Multnomah County within the City of Portland, and City of Happy Valley within Clackamas County's' Service District no. 1 (CCSD\#1) MS4 boundary. City of Milwaukie is additionally a copermittee with Clackamas County. However, unlike Happy Valley, which is included in CCSD\#1's SWMP, Milwaukie implements its own SWMP. Although the Clackamas County copermittees, including City of Milwaukie and City of Happy Valley are considered Phase II agencies, collectively the co-permittees are considered Phase I agencies because they serve a population of greater than 100,000 individuals. Initial SWMPs constructed in 1993 by each of the MS4 agencies established several common BMP categories including Public Involvement and Education, Operation and Maintenance, Illicit Discharge Dry Weather Monitoring, New and Redevelopment Projects, and Structural Controls. NPDES permit cycles, SWMPs, and annual stormwater BMP progress for each of the DMA's will be reviewed later in this document.

\section{TMDL Implementation Background}

BMPs used to minimize nonpoint source bacterial loading into the stream are addressed through a TMDL implementation plan. In Oregon a TMDL implementation plan is required to include, at a minimum, management strategies to meet loading reductions, a timeline of implementation, project milestones, and performance measures, a plan for periodic revision of the implementation plan, and evidence of compliance with state land use requirements (OAR 340-042-0025).

Following the approval of the Lower Willamette TMDL in September of 2006 by EPA, DMAs within the Johnson Creek Watershed were directed to develop a TMDL implementation plan. DMAs were provided general guidance regarding applicable BMP categories and a list of 
sufficient management strategies already addressed in other documents such as stormwater management plans. All DMAs within the Johnson Creek Watershed, with the exception of ODA and ODF as stated by OAR 340-042-0080 (4), are required to construct TMDL implementation plans. ODF is not required to develop an implementation plan because it is in compliance with the Oregon Forests Practices Act. ODA is required under the Agricultural Water Quality Management Act to develop area rules and an area plan. If a TMDL is in place, an area plan developed by ODA is required to include strategies to meet load reductions designated by the TMDL. All DMAs with the exception of ODA and ODF are required to submit to DEQ annual reviews of TMDL implementation activities. Every 5 years, DMAs are required to report milestones from the previous 4 years and revise recommendations for the TMDL implementation plan, subject to review and approval by DEQ. While ODA is not required to submit an annual review to DEQ, ODA submits a biennial review of their area plan to a local advisory committee (LAC) that reviews and makes suggestions for future area plan revisions. Common strategies to address nonpoint sources which will be reviewed further in this document, includes removing septic systems and connecting these properties to the municipal sanitary sewer, educating pet owners to pick up pet waste, educating septic system owners about proper maintenance scheduling, and extending sanitary sewer service area to rural communities. 


\section{Structural \& Nonstructural BMPs}

\section{Structural BMPs}

Structural BMPs are facilities used to treat or reduce stormwater runoff prior to entry into either the storm sewer system or receiving surface waters (EPA, 1999). As previously mentioned in this document, structural BMPs may either reduce the volume or concentration of pollutant loads to the stream. Pollutants may be mobilized during precipitation events from rooftops, parking lots, and streets and enter the storm sewer system; eventually discharging into nearby streams. Potential sources of $E$. coli from streets, rooftops, and parking lots are pets, homeless encampments, and birds. Transport mechanisms for these sources include direct runoff from impervious surfaces, discharge from stormwater systems, and direct defecation into the stream. The expansion of urban areas within watersheds has increased the prevalence of these sources through alteration of the natural hydrology and installation of conveyance systems. Urban expansion has led to increases in impervious surfaces, promoting less stormwater infiltration to land surfaces and increasing stormwater runoff. Increases in impervious surfaces may not impact water quality unless there is a hydrological connection to pollutant sources. Conveyance systems such as stormwater pipes pose a risk to stream water quality because they are directly connected to streams and greatly reduce the travel time required for a pollutant to enter a stream. The implementation of treatment and volume reduction or flow control BMP facilities, therefore, are needed to reduce pollutant concentrations and to minimize the input volume of stormwater to conveyance systems (Field, 2006).

Volume and pollutant reduction BMPs used to treat E. coli as well as other pollutants may be divided into several major categories including ponds, vegetation biofilters, infiltration 
facilities, sand/organic filters, and vendor-supplied technology (Table 6). Ponds and infiltration facilities are used to control the volume of stormwater entering storm sewer systems, while vegetation biofilters, sand/organic filters, and proprietary treatment technologies are used to reduce the concentration of stormwater entering storm sewer systems.

Ponds and infiltration facilities, the two structural BMP categories used to control stormwater runoff volume, fundamentally differ in the way they function (Field, 2006). Stormwater ponds temporarily hold stormwater to prevent peak flows during storm events. Ponds may either have a permanent pool of water (wet retention pond) or have a pool of water only during storm events (dry detention pond). Retention ponds are overall more effective than detention ponds as they are able to hold stormwater even after storm events, while detention ponds typically are not able to hold stormwater for a period of time greater than 24 hours (Field, 2006). While stormwater ponds temporarily hold stormwater, infiltration facilities are designed to retain water by percolating it into the soil. Stormwater is received by infiltration type BMPs either directly or by diverting storm sewer pipes with a flow splitter or weir to discharge into these facilities. Porous pavement and infiltration trenches are examples of BMPs that directly receive stormwater, while infiltration basins are an example of an end of pipe BMP.

The major difference between ponds and infiltration facilities is that infiltration facilities convert surface flow into groundwater flow while ponds hold surface water for a short period and then release into nearby streams. Infiltration facilities have certain advantages over ponds such as the ability to recharge aquifers (increases streamflow during dry season) and provide partial treatment to stormwater as it percolates through soils. However, infiltration facilities are not appropriate for use in regions with high soil permeability (Field, 2006). In contrast to volume reducing BMPs, major structural BMP treatment categories for stormwater all operate by 
filtering and removing pollutants from runoff. The major differences between treatment categories is the media used for filtration and the process by which stormwater is transferred to facilities. The major categories of stormwater filters are vegetative biofilters (swales and bioretention cells), sand/organic filters, and vendor supplied technologies (catch basins, hydrodynamic devices, filtration devices). Sand filters in particular have shown to be effective in removing bacteria from stormwater, while vegetative biofilters such as swales, and vendor supplied technology such as hydrodynamic devices have shown to be ineffective. Although swales have not been shown to be very effective in removing bacteria from stormwater, they have been shown to moderately reduce volume levels (City of Gresham, 2014).

Filters generally are designed to receive stormwater from the end of a pipe rather than at the site where the pollutant originated (Field, 2006). Vegetative biofilters such as swales and bioretention cells however, are referred to as conveyance BMPs because they treat runoff prior to entry into stormwater systems. Therefore, these facilities generally cover more area than end of pipe facilities to treat runoff from rooftops, parking lots, and streets. Implementation of end of pipe stormwater filters is a favorable option for highly urbanized areas where little land is available for development. Non-end of pipe filters such as swales are typically incorporated into the design of sidewalks or parking lots in developing areas. Although filtration systems can be relatively effective in removing bacteria from stormwater runoff, they are not generally designed to treat a large volume of stormwater. Therefore, bypass will occur if the treatment capacity of a filter is exceeded (Field, 2006). 
Table 6. Low Impact Development and proprietary structural BMPs

\begin{tabular}{|c|c|c|}
\hline $\begin{array}{l}\text { Major } \\
\text { Categories }\end{array}$ & Structural BMPs & Type \\
\hline Ponds $^{*}$ & $\begin{array}{ll}\text { - } & \text { Dry Detention Ponds } \\
\text { - } & \text { Dry-Extended Detention Ponds } \\
\text { - } & \text { Wet Retention Ponds }\end{array}$ & Volume Reduction \\
\hline $\begin{array}{l}\text { Vegetative } \\
\text { Biofilters* }\end{array}$ & $\begin{array}{ll}\text { - } & \text { Grass Swales } \\
\text { - } & \text { Filter Strips } \\
\text { - } & \text { Bioretention Cells }\end{array}$ & $\begin{array}{l}\text { Pollutant and } \\
\text { Volume Reduction }\end{array}$ \\
\hline $\begin{array}{l}\text { Infiltration } \\
\text { Facilities* }\end{array}$ & $\begin{array}{ll}\text { - Infiltration Trench } \\
\text { - Infiltration Basin } \\
\text { - }\end{array}$ & Volume Reduction \\
\hline $\begin{array}{l}\text { Sand and } \\
\text { Organic Filters* }\end{array}$ & $\begin{array}{ll}\text { - } & \text { Sand Filter } \\
\text { - } & \text { Media Filter }\end{array}$ & Pollutant Reduction \\
\hline $\begin{array}{l}\text { Vendor-Supplied } \\
\text { Technology }^{* *}\end{array}$ & $\begin{array}{ll}\text { - } & \text { Catch Basin Inserts } \\
\text { - } & \text { Hydrodynamic Devices } \\
\text { - } & \text { Filtration Devices }\end{array}$ & Pollutant Reduction \\
\hline
\end{tabular}

*=Low Impact Development structural BMPs

$* *=$ Proprietary treatment technologies

***Information for table from (WEF and ASCE, 1998), (EPA, 1999), and (Field, 2006)

\section{Nonstructural BMPs}

Nonstructural or source control BMPs are practices that prevent pollutant loading by reducing or eliminating potential sources before they come into contact with stormwater. These BMPs include several different major categories such as public education, land use planning and management, street/stormwater maintenance, and illicit connection control (Table 7). The first BMP category, public education, focuses on reducing E. coli loading to streams by targeting two primary sources: pet waste and septic systems. Pet waste and septic system failures are addressed under this category by informing pet owners of proper pet waste disposal in public areas and by educating onsite septic system owners about proper maintenance activities needed to avoid system failure.

Planning and management of land use, the second major nonstructural BMP category, is vital to mitigate the impacts of urbanization. Expansion of impervious surfaces due to the 
development of urban environments can alter natural flow regimes, chemical composition, and biota within a stream by increasing surface water runoff during storm events. Planning and land use management strategies to minimize stream water quality impacts from urban development include conservation easements and incorporation of low impact development engineering concepts such as porous pavements into urban environments (Field, 2006).

Maintenance of roads and stormwater facilities, the third major nonstructural BMP category, helps to prevent exposure of contaminants to stormwater and ensure that stormwater facilities are functioning properly. Street sweeping, catch basin cleaning, and structural BMP maintenance are primary examples of strategies that fall under this category. Street sweeping is intended to prevent sediment and attached associated pollutants such as bacteria and litter from entering the stormwater system. The practice is considered to be highly effective and is an especially well suited strategy for residential, commercial, and industrial areas with little additional space for adding structural BMPs. Studies have shown that routine street sweeping on a weekly or bimonthly basis may potentially reduce annual loading of waste to the storm sewer by 48-90\% (FHWA, 2000; Kang et al., 2009; Seattle Public Utilities, 2009). However, with street sweeping frequencies of 9-12 times a year for MS4 agencies within Johnson Creek, loading reduction of waste is estimated to be around 10\% (City of Gresham, 2014).

In addition to street sweeping programs, catch basins are another technology to reduce sediment and associated pollutant loading to streams. . Catch basins typically have a sumped portion that can capture 1-3 cu ft. of sediment and litter before it enters the piped system. Periodic cleaning of catch basins is needed to prevent the build-up of solids and ensure proper functioning. Infrequent catch basin maintenance increases the likelihood of bypass, leading to direct inputs of waste into the storm sewer. Low impact development structural BMPs like catch 
basins, require periodic maintenance. Proper functioning of low impact development structural BMPs may require activities such as sediment removal and vegetative maintenance to maximize stormwater infiltration and treatment (Field, 2006).

The final major nonstructural BMP category, illicit connection control targets illicit connections to the storm sewer system. Illicit connections may be either direct or indirect. Direct connections may include piping of sanitary or industrial wastewater to the storm sewer. Indirect connections to the storm sewer by contrast, does not represent a physical connection of pipes from other systems to the storm sewer. A common example of an indirect connection is the entry of wastewater from either a leaking sanitary sewer line (called exfiltration) or failing septic system into the stormwater system. Corrections of illicit connections may require the removal of direct illicit connections, repairs to external piping systems, and/or repair or removal of failing septic systems. The most commonly used methods to detect illicit connections is through dryweather inspections of major storm sewer outfalls and TV inspection of lines when new pipes are installed. During dry-weather months (June-September for Johnson Creek) stormwater discharge is expected to be minimal, therefore, flow during dry-weather months may indicate the presence of an illicit connection. Once an illicit connection has been detected, the source may be identified through further investigation of the storm sewer system and surrounding area. 
Table 7. Common Nonstructural BMPs for Urban Stormwater Run-off.

\begin{tabular}{|l|l|l|}
\hline Major Categories & Nonstructural Practice \\
\hline Public Education & $\bullet$ & Education and Outreach \\
\hline Planning and & $\bullet$ & Reduction/Disconnection of Impervious Areas \\
Management & $\bullet$ & Low-Impact Development (LID) * \\
\hline Street/Storm Drain & $\bullet$ & Street Sweeping \\
Maintenance & $\bullet$ & Catch Basin Cleaning \\
& $\bullet$ & Structural BMP Maintenance \\
\hline Illicit Connection & $\bullet$ & Illicit Connection Prevention \\
Control & $\bullet$ & Illicit Connection Detection and Removal \\
& $\bullet$ & Leaking Sanitary Sewer and Septic Tank Control/Removal \\
\hline
\end{tabular}

* Considered a structural or nonstructural BMP depending on the implementation phase. During planning and development phase LID areas are classified as nonstructural, however, once formally implemented they are classified as structural BMPs. (WEF and ASCE, 1998) 


\section{Study Sites}

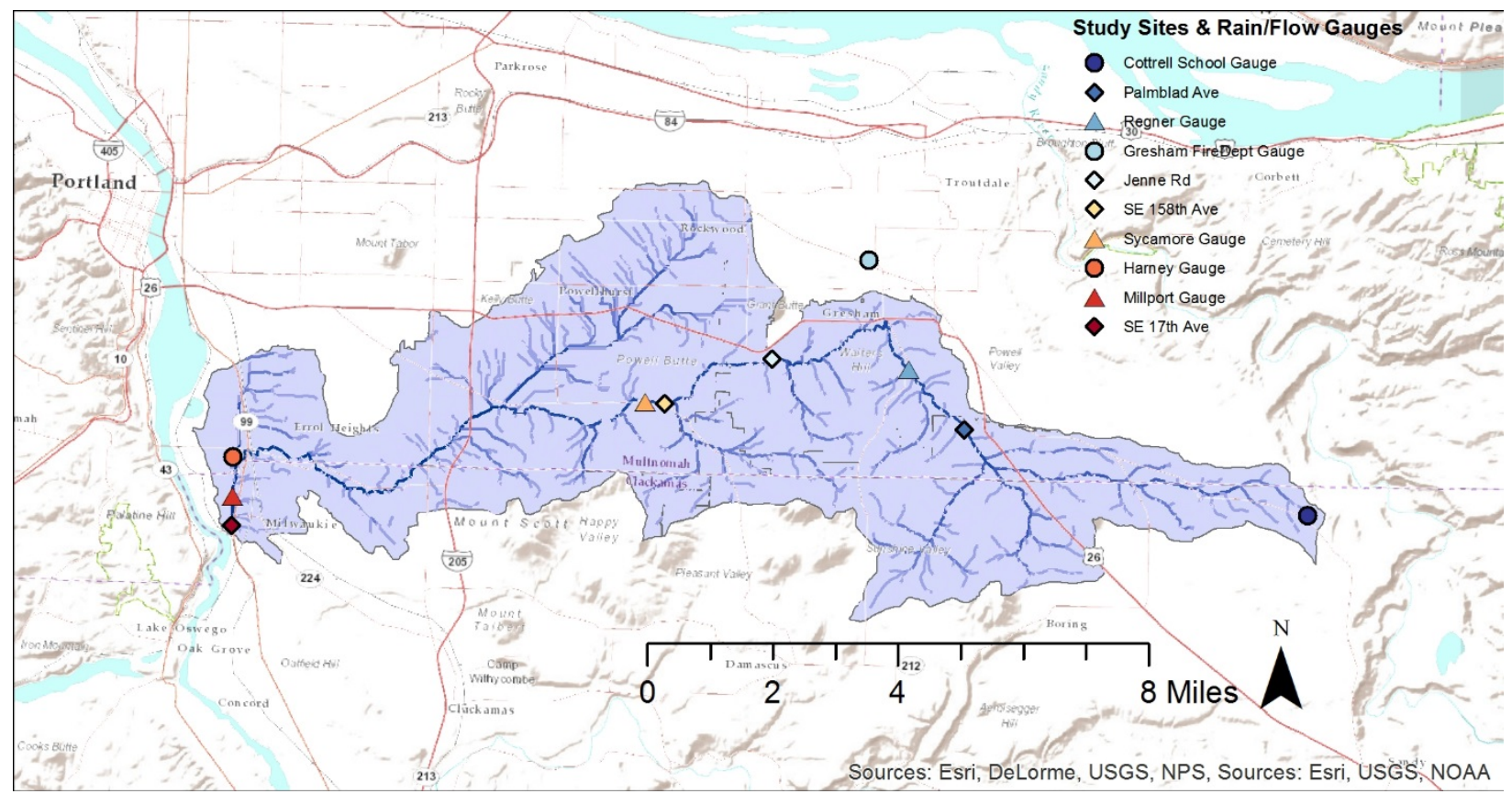

Figure 4. Study sites, rain gauges, and flow gauges in Johnson Creek. Study sites, rain gauges, and flow gauges are represented by diamonds, circles, and triangles respectively.

Four sites (Palmblad, Jenne Rd., SE $158^{\text {th }}$ Ave, and SE $17^{\text {th }}$ Ave) were selected for assessment of water quality conditions in the watershed. Sites were selected accordingly based on both the spatial location within the watershed and the extent of years of available water quality data from prior to TMDL implementation (2006) to either 2015 or 2016 . The study sites account for the agricultural portion of the upper watershed (Palmblad), the middle of the creek (Jenne Rd and SE $158^{\text {th }}$ Ave), and the mouth of the creek (SE 17 th Ave) (Figure 4). The sites selected are influenced by both land use from upper regions in the watershed, and land use in immediately surrounding areas. As mentioned above, the watershed is predominately urbanized with the exception of unincorporated Clackamas County in the middle and upper reaches of the watershed, and unincorporated Multnomah County in the upper reaches of the watershed (Figure 2 and Figure 4). 
The drainage area of Palmblad, the uppermost site in the watershed, is approximately 7,992 acres (Table 9). Bacterial loading to Palmblad is expected to be associated with rural and agricultural land uses from unincorporated regions in the upper watershed. The drainage area of Jenne Rd and SE $158^{\text {th }}$ Ave, the sites near the middle of the watershed, is approximately 13,255 acres and 16,716 acres, respectively (Table 9). Jenne Rd is located in Gresham and is within close proximity to the Spring Water Corridor, a 20-mile bike route that contains several homeless encampments. SE $158^{\text {th }}$, on the other hand, is located in the middle of the watershed near Portland and is surrounded by residential land use. The drainage area for SE $17^{\text {th }}$, the final study site, accounts for approximately the entire watershed (34,035 acres) (Table 9). SE $17^{\text {th }}$ is located in Milwaukie near the mouth of the watershed and is completely surrounded by industrial land use.

Sampling frequency and the range of dates with available bacteria data varied between study sites. E. coli water quality data at Palmblad and Jenne Rd. were collected by City of Gresham, E. coli water quality data for SE $158^{\text {th }}$ Ave were collected by City of Portland, and E. coli water quality data at SE $17^{\text {th }}$ Ave were collected by DEQ (Table 8.).

Data were collected at the DEQ sampling site (SE $17^{\text {th }}$ Ave) approximately 6 times a year from 1996-2015 (Table 8). The City of Portland site (SE $158^{\text {th }}$ Ave) was sampled on average 4 times a year prior to 2004, after which sampling occurred approximately once a month (Table 10.). City of Gresham sites (Palmblad and Jenne Rd.) were sampled on average 10 times a year from 2000-2016. DEQ bacterial water quality data (SE $17^{\text {th }}$ Ave) contained the greatest range of dates (1996-2016), and City of Gresham data contained the shortest range of dates (1999-2016) (Table 8). 


\section{Methods}

\section{Water Quality- Bacteria}

Objectives of this analysis included:

- Assessment of historical bacterial water quality trends,

- Determination if bacterial water quality standards were being met,

- Prediction of future conditions,

- Assessment of the relationship between bacterial water quality and environmental parameters, and

- Determination of effectiveness of structural and nonstructural BMPs implemented by each of the DMAs following the issuance of 2006 TMDL.

Bacterial water quality data were obtained from the DEQ Laboratory Analytical Storage and Retrieval (LASAR) database, from the Johnson Creek Watershed Council, and from the DEQ ELEMENT database.

Water Quality Data Preparation

Bacterial water quality data obtained from both LASAR and ELEMENT contained values that exceeded the maximum detection limit for laboratory assessment. Values above the maximum were reported as the upper detection limit. Additionally sites sometimes contained sampling duplicates. All sampling duplicates were averaged to yield one bacterial concentration

per day. The laboratory assessment method for all data used in this study was Colilert QT, one of the two methods approved by the EPA, the other being membrane filtration. Unlike the 
membrane filtration method which consists of filtering E. coli colonies from a water sample, and then counting the number of $E$. coli colony forming units (cfu) (from membrane filter) under a microscope, the Colilert QT method approximates the most probable number (MPN) of E. coli (Eckner, 1998).

\section{Study Site Selection}

E.coli water quality data were available for 15 sites spanning from Palmblad Rd in the lower agricultural region of the upper watershed, to the mouth of the Creek at SE $17^{\text {th }}$ Ave. Sampling frequency and the range of dates with available bacteria data varied between DMAs (DEQ, City of Gresham, and City of Portland). Data was collected at the DEQ sampling site (SE $17^{\text {th }}$ Ave) approximately 6 times a year from 1996-2015 (Table 8.). City of Portland sites were sampled on average 4 times a year prior 2004, after which sampling occurred approximately once a month (Table 8.). City of Gresham sites were sampled on average 10 times a year from 2000-2016. The 30 day, 5 sample minimum criterion required to assess the $126 \mathrm{cfu} / 100 \mathrm{~mL}$ geometric mean bacteria standard was not met by any of the DMAs. Therefore, the $126 \mathrm{cfu} / 100$ $\mathrm{mL}$ geometric mean standard could not be evaluated in any descriptive statistical analyses. Therefore, the $406 \mathrm{cfu} / 100 \mathrm{~mL}$ non-exceedance standard was assessed instead. The $126 \mathrm{cfu} / 100$ $\mathrm{mL}$ standard was only assessed with the load duration method, which evaluates the geometric mean loading within different flow categories, rather than intervals of time.

While data are available for 15 sites, 6 sites (SE $159^{\text {th }}$, SE $55^{\text {th }}$, Hogan Road, Sycamore Road, Linwood Ave, and Luther Road) had $\leq 1$ year of data. Therefore, only 9 of the 15 sites were considered for further analysis. Further, only four sites within the watershed (Palmblad, Jenne Rd, SE $158^{\text {th }}$ Ave, and SE $17^{\text {th }}$ Ave) contained data from before the TMDL. Thus, these 
four sites were selected for the study. These sites accounted for the upper watershed (Palmblad), the middle of the creek (Jenne Rd and SE $158^{\text {th }}$ Ave), and the mouth of the creek (SE $17^{\text {th }}$ Ave).

Table 8. Data sources used in analysis

\begin{tabular}{|c|c|c|c|c|}
\hline Parameter & Data Source & Data Range & $\begin{array}{l}\text { Parameter } \\
\text { Location }\end{array}$ & $\begin{array}{l}\text { Parameter } \\
\text { Frequency }\end{array}$ \\
\hline E. coli & $\begin{array}{l}\text { City of Portland } \\
(\mathrm{COP})\end{array}$ & 1996-2015 & 11 & $\begin{array}{l}\text { Monthly } \\
(>2003)\end{array}$ \\
\hline E. coli & $\begin{array}{l}\text { City of Gresham } \\
(\mathrm{COG})\end{array}$ & 1999-2016 & 2 & $\begin{array}{l}\text { Bimonthly } \\
(>2003)\end{array}$ \\
\hline E. coli & DEQ & 1996-2016 & 1 & Bimonthly \\
\hline \begin{tabular}{|l|} 
Streamflow \\
\end{tabular} & USGS & $1996-2016$ & $\begin{array}{l}3 \text { gauged sites } \\
7 \text { ungauged } \\
\text { estimates }\end{array}$ & Continuous \\
\hline Population & U.S Census Bureau & $1990,2000,2010$ & $\begin{array}{l}\text { COG, COP, COM, } \\
\text { Happy Valley, } \\
\text { Multnomah County, } \\
\text { Clackamas County }\end{array}$ & Decennial \\
\hline BMP's & $\begin{array}{l}\text { COP,COM, COG, } \\
\text { Happy Valley, } \\
\text { Counties, DEQ, } \\
\text { ODA, ODF }\end{array}$ & 1993-2016 & $\begin{array}{c}\text { Throughout COP, } \\
\text { COM, and COG } \\
\text { jurisdiction }\end{array}$ & Unknown \\
\hline Land Use & NLCD & $\begin{array}{l}\text { 1992, 2001, 2006, } \\
2011\end{array}$ & N/A & N/A \\
\hline Precipitation & $\begin{array}{l}\text { OSU PRISM and } \\
\text { Portland HYDRA } \\
\text { Network }\end{array}$ & \begin{tabular}{|ll}
1. & $\begin{array}{l}\text { 1996-2016 } \\
\text { (PRISM) }\end{array}$ \\
2. & $\begin{array}{l}1998-2016 \\
\text { (HYDRA } \\
\text { Network rain } \\
\text { gauges) }\end{array}$
\end{tabular} & $\begin{array}{ll}\text { 1. } & 15 \text { (PRISM) } \\
\text { 2. } & 3 \text { rain gauges }\end{array}$ & $\begin{array}{ll}\text { 1. } & \text { Annual } \\
\text { 2. } & \text { Daily }\end{array}$ \\
\hline
\end{tabular}




\section{Climate -Streamflow, Precipitation}

Climate data in this study were obtained from the United States Geologic Survey (USGS) National Water Information System Web Interface for daily streamflow, from the Oregon State University PRISM climate group for annual precipitation GRID files (to determine annual average precipitation values for regions of interest within the watershed), and daily precipitation from the Portland HYDRA Rainfall Network. Daily streamflow data were available for only the SE $17^{\text {th }}$ site, however, the Sycamore gauge in the middle of the watershed (approximately SE $158^{\text {th }}$ ), and the Regner gauge (near Palmblad) in the upper watershed were used to approximate values for SE $158^{\text {th }}$, Jenne Rd, and Palmblad. The date range for streamflow data used in this study was selected to coincide with the earliest date of available bacteria data to present day (1996-2016). Daily precipitation data from the Portland HYDRA Rainfall Network was not available until June of 1998. Therefore, daily precipitation data from 1998-2016 was used. The Cottrell School rain gauge was used for Palmblad, the Gresham Fire Department rain gauge was used for Jenne Rd and SE $158^{\text {th }}$ Ave, and the Harney rain gauge was used for SE $17^{\text {th }}$ Ave. Precipitation data were extracted from the Portland HYDRA Rainfall Network using the package “hail” in R 3.3.1. 


\section{Descriptive Statistics}

An initial visual assessment of water quality data was conducted using boxplots. Boxplots were constructed for Palmblad, Jenne Rd, Se $158^{\text {th }}$ Ave, and SE $17^{\text {th }}$ Ave. The boxplots were evaluated over time (1999-2016 for Palmblad and Jenne Rd, 1996-2015 for SE $158^{\text {th }}$, and 1996-2016 for SE $17^{\text {th }}$ Ave) and were categorically grouped based off of the number of exceedances of the $406 \mathrm{cfu} / 100 \mathrm{~mL}$ single sample standard. The number of samples collected per year was superimposed onto each boxplot to allow for standardization of the data that preserves the actual number of exceedances.

\section{Trend Analysis}

Bacteria

Bacterial trend analysis was conducted for Palmblad, Jenne Rd, SE $158^{\text {th }}$ Ave, and SE $17^{\text {th }}$ Ave to assess whether or not $E$. coli concentrations were significantly increasing or decreasing over time. Trends were assessed for each site using Seasonal Mann Kendall, a nonparametric method for regression analysis and an extension of the Mann Kendall Test. Hirsch et al. (1982) found that the distribution of water quality data is typically highly skewed and that the use of non-parametric tests such as Mann Kendall or Seasonal Mann Kendall may be more appropriate under these circumstances due to their higher ability to reject a false null hypothesis. The E. coli water quality data in this study were found to have a skewed distribution over time for each of the sites. Therefore, Seasonal Mann Kendall was selected for analysis of bacterial time series data rather than parametric regression. The Seasonal Mann Kendall Test is slightly differently than the Mann Kendall test in that the difference of terms (bacterial concentrations) are calculated only for the same months or seasons over time (e.g., the differences of January 
data from different years) rather than for every possible combination of differences calculated in the Mann Kendall Test. The differences of each month or season from previous time periods yields three different possibilities of terms which when summed yield a test statistic S. This test statistic is used to determine Kendall's Tau which describes the overall direction of the linear trend. The Mann Kendall and Seasonal Mann Kendall both only assess whether or not a monotonic trend is present. The alternative hypothesis in this study was that if $\mathrm{P}<0.1$ than there was a significant linear trend, otherwise no monotonic trend was assumed to be present. The direction of a trend, if present is identified by Kendall's Tau. A positive or negative Kendall's Tau would indicate that the parameter (E. coli) is increasing or decreasing over time, while a Kendall's Tau of zero would indicate no change of the parameter over time.

\section{Streamflow}

Streamflow is an important variable to assess when analyzing pollutant loading. High streamflow allows for higher loading capacity of pollutant parameters. While large loading events during high flow events may result in water quality exceedances, these events are typically transient in nature and will quickly be discharged downstream (BES, 1994). Conversely, lower flow events allow for lower loading capacity and may result in longer residence time of pollutant parameters.

Trend analysis of streamflow over the last two decades (1996-2016) was conducted for the upper, middle, and lower reaches of the Johnson Creek Watershed using data from Palmblad Rd (estimated), Sycamore Gauge, and Millport Rd Gauge respectively. To assess streamflow trends, $0^{\text {th }}\left(\mathrm{Q}_{0}\right), 10^{\text {th }}\left(\mathrm{Q}_{10}\right), 30^{\text {th }}\left(\mathrm{Q}_{30}\right), 70^{\text {th }}\left(\mathrm{Q}_{70}\right), 90^{\text {th }}\left(\mathrm{Q}_{90}\right)$, and $100^{\text {th }}\left(\mathrm{Q}_{100}\right)$ percentile events were calculated for each water year (Oct1- Sept 30) from 1996-2016. A percentile yields the probability of an event being below it, in other words, a $0^{\text {th }}$ percentile event is the minimum
53 | P a g e
Final Report: October 23, 2017 
event for a given year, and the $100^{\text {th }}$ percentile is the maximum event for a given year. The Mann Kendall Test was used to assess whether or not there was a significant increasing or decreasing monotonic trend over time for $0^{\text {th }}$ percentile events, $10^{\text {th }}$ percentile events, $30^{\text {th }}$ percentile events, $70^{\text {th }}$ percentile events, $90^{\text {th }}$ percentile events, and $100^{\text {th }}$ percentile events. Time series models for each of the different percentile flow events were assessed using the R 3.31 package 'mannKen'. The Slope of the trend line for each time series model, known as 'Theil's Slope' was determined using the package 'MannKendall' in R 3.31. Theil's Slope provided the monotonic increase or decrease for streamflow in units of cubic feet per second per year. The null hypothesis for each of the Mann Kendall Tests were that there were no monotonic trends present. The alternative hypothesis for each of Mann Kendall Tests were that there was a significant increasing or decreasing monotonic trend. If $\mathrm{p}<0.1$ then the null hypothesis was rejected and the direction of the monotonic trend was determined by the value of Kendall's Tau (positive values indicate increasing trends, while negative values indicate decreasing trends).

\section{Precipitation}

Precipitation like streamflow is an important variable to assess when evaluating major factors contributing to pollutant loading. As a highly urbanized watershed with approximately $50 \%$ impervious surface coverage, Johnson Creek is known to exhibit 'flashy' runoff events during high precipitation events (ODEQ, 2006). Phase I MS4 permitted agencies within the watershed are required to construct stormwater facilities that treat $80 \%$ ( $90 \%$ for Portland) of the average annual rainfall each year. The design capacity for the facilities for each of the different MS4 agencies within the watershed vary according to assessments of regional precipitation. City of Gresham, Portland, and Milwaukie detention facilities are capable of storing 1.2 inches/12 hr, 
0.83 inches/24 hr, and 0.83 inches/ $24 \mathrm{hr}$ respectively for precipitation events (City of Eugene, 2014) and (City of Milwaukie, 2009)

Runoff within a watershed is dependent on several factors, the most important of which includes the impervious surface coverage, regional slopes within the watershed (topography), and the hydrologic connection between regions in which surface runoff is occurring and the stream. Regional studies relating precipitation rates that are effective to initiate stormwater runoff into the stream (either into the MS4 or direct surface flow) are scarce. DEQ assumed that 0.15 inches of precipitation within a 24 hour period would be sufficient to initiate runoff (ODEQ, 2006). A study by Hood et al. (2007) found that the precipitation threshold during a storm event for urban watersheds (study represented an urban watershed as one with 32\% impervious surface) was 3mm (0.12 inches).

Trend analysis was conducted for precipitation using data from three gauges within the watershed (Figure 4). The Cottrell School rain gauge was used to assess precipitation trends in the upper watershed, the Gresham Fire Dept. rain gauge was used to assess precipitation trends for the middle of the watershed (and Gresham), and Harney rain gauge was used to assess precipitation trends for the lower reaches of the watershed. As previously mentioned, Portland HYDRA Network precipitation data became available in 1998. Precipitation trends were assessed using water years (Oct 1- Sept 30 ${ }^{\text {th }}$ ), therefore, water years 1999-2016 were assessed. $90^{\text {th }}\left(Q_{90}\right)$ and $100^{\text {th }}\left(Q_{100}\right)$ percentile events were calculated for each year for each of the three sites. $90^{\text {th }}$ and $100^{\text {th }}$ percentile events were selected for a trend assessment because these events contained precipitation values capable of exceeding the storage capacity of stormwater detention facilities for City of Gresham, Portland, and Milwaukie. The Mann Kendall Test was used to assess whether a monotonic trend was present for precipitation time series data for $90^{\text {th }}$ percentile 
events, and $100^{\text {th }}$ percentile events. Mann Kendall Test was conducted in R 3.31 using the “mannKen” package, and the "MannKendall” package was used to determine the slope of each time series model. The null hypothesis was that there would be no monotonic trend present, while the alternative hypothesis was that there was an increasing or decreasing monotonic trend for $90^{\text {th }}$ or $100^{\text {th }}$ percentile precipitation events. The direction of the trend for each of the models was determined by the sign of Kendall's Tau (positive indicates increasing trend, while negative sign indicates a decreasing trend). The null hypothesis was rejected in this study if $\mathrm{P}<0.05$.

\section{E. coli vs. Precipitation}

A regression analysis of $E$. coli concentrations vs. precipitation was conducted. Cottrell School rain gage was used for Palmblad study site, Gresham Fire Dept. rain gage was used for study sites Jenne Rd and SE $158^{\text {th }}$, and Harney rain gage was used for the SE $17^{\text {th }}$ study site. Precipitation values used in this assessment were selected to correspond to the cumulative amount of precipitation for consecutive hours of rainfall prior to the collection of an E. coli grab sample (nearest hour) for a given sampling date. For example, if there was 8 consecutive hours of rainfall and two hours of no precipitation prior to collection of a grab sample, the 8 hour precipitation value would be selected. Best judgement however, was used in place of this method in certain circumstances, for instance if a large storm event ceased for an hour and then reoccurred, the precipitation value selected would be the sum of the storm event prior to collection of the E. coli sample.

To assess whether or not runoff events were influencing in stream E. coli concentrations a regression analysis was performed. A regression model of $\log _{10}$ transformed E. coli data vs. cumulative precipitation for consecutive hours of rainfall prior to collection of an E. coli grab sample for a given day was performed for each study site: Palmblad Ave, Jenne Rd, SE $158^{\text {th }}$ 
Ave, and SE $17^{\text {th }}$ Ave. Days in which there was no precipitation were not included in the model. I hypothesized that if runoff entered the stream, that there would be a log linear relationship between in stream E. coli concentrations and the amount of precipitation during a storm event. The null hypothesis, conversely, was that there would be no relationship between in stream $E$. coli concentrations and the amount of precipitation accumulated during a storm event. This could indicate a lack of hydrologic connections to the stream or that stormwater detention facilities are capturing all of the runoff. If $\mathrm{P}<0.05$ the null hypothesis was rejected and the relationship between $E$. coli and precipitation was deemed to be log-linear.

\section{Stream Network/ Sub-Watershed Delineation}

A stream network and watershed layer were created from a Digital Elevation Model (DEM) raster of Johnson Creek using the ArcGIS hydrology toolbox (a subset of Spatial Analyst Tools). The DEM file was used as an input to the flow direction and flow accumulation tools respectively, to create a stream network. Once a stream network was created shapefiles for each of the 15 initial study sites were geocoded using coordinates obtained from Google Maps (GCS_NAD_1983_2011). The 15 shapefiles were then used as inputs into the watershed tool to create 15 sub-watershed regions (total area contributing to flow) corresponding to each of these sites. The sub-watershed regions were necessary to approximate the exposure of each sampling site to both climate and population variables, as well as to estimate streamflow for ungauged sites. 


\section{Streamflow Estimation}

USGS daily streamflow data were available for 3 gauges within the watershed (Regner Rd, Sycamore Rd, and Millport Rd) (Table 5). Streamflow data for SE $17^{\text {th }}$ Ave was represented by flow values from the Millport Rd gauge which is in close proximity (Figure 4). Flow values for the other 3 study sites were determined by using a variation of the drainage area ratio method. The drainage area ratio method is a widely used and straight forward method for calculating streamflow (Emerson et al., 2005). The basic assumption of the method is that streamflow for an ungauged site within a watershed can be estimated by taking the product of flow from a gauged site with the ratio of the subwatershed area for gauged and ungauged sites (Gianfagna et al., 2015). The method used in this document incorporated the ratio of spatially averaged annual precipitation for gauged and ungauged subwatershed regions as an additional factor (Dayyani et al., 2003) (Equation 1).

Annual precipitation data required for the model were acquired from PRISM Climate Group; the R package prism was used to project (NAD_1983_2011_

Oregon_Statewide_Lambert), clip, convert grid values from millimeters to inches, and to export GRID files of sub-watershed regions to ArcGIS. While this process could be performed in ArcGIS, PRISM GRID files account for the entire U.S and are, therefore, very memory intensive to work with directly in ArcGIS. Spatially averaged annual precipitation, expressed in inches, was calculated for each of the sub-watershed regions for the years 1996-2016 using zonal statistics in ArcGIS.

Flow for ungauged sites was approximated through an iterative process that used flow data from either stream gauges or previously approximated sites. Sites with flow data available 
that were within the closest proximity (subwatershed ratio closest to 1 ) to the site of interest were used to determine flow. Seven sites (2 sites at a stream gauge) from Sycamore Gauge to Palmblad Ave. were used to approximate streamflow (Figure 5). Streamflow approximations included 3 sites (SW Pleasantview Dr., Regner Road, and Hogan Road) that lacked comprehensive E.coli water quality data, as a result, flow approximations were more localized than they would have been if only the reduced sites and stream gauges were used in the model. The validity of this model was tested using two gauged sites (Regner and Sycamore) and a succession of ungauged sites with approximated flow. Sycamore streamflow data was used as a model input to approximate discharge for the nearest ungauged site (SE $158^{\text {th }}$ ) which was then used as an input to determine flow for the next ungauged site (Jenne Rd) etc. Through this stepwise process flow was approximated for Regner Rd. Once flow values were approximated for Regner Rd they were compared with the actual flow values from the Regner gauge. Using the R package hydroGOF, a Pearson correlation coefficient, and normal root mean square error (NRMSE) value were used to determine the goodness of fit of the model for the Sycamore and Regner Road gauges $\left(\mathrm{R}^{2}=0.98\right.$, NRMSE $\left.=16.7 \%\right)$. These results indicate a strong correlation between predicted and actual discharges value and an approximate deviation of $16.7 \%$ of predicted values from observed discharge. 


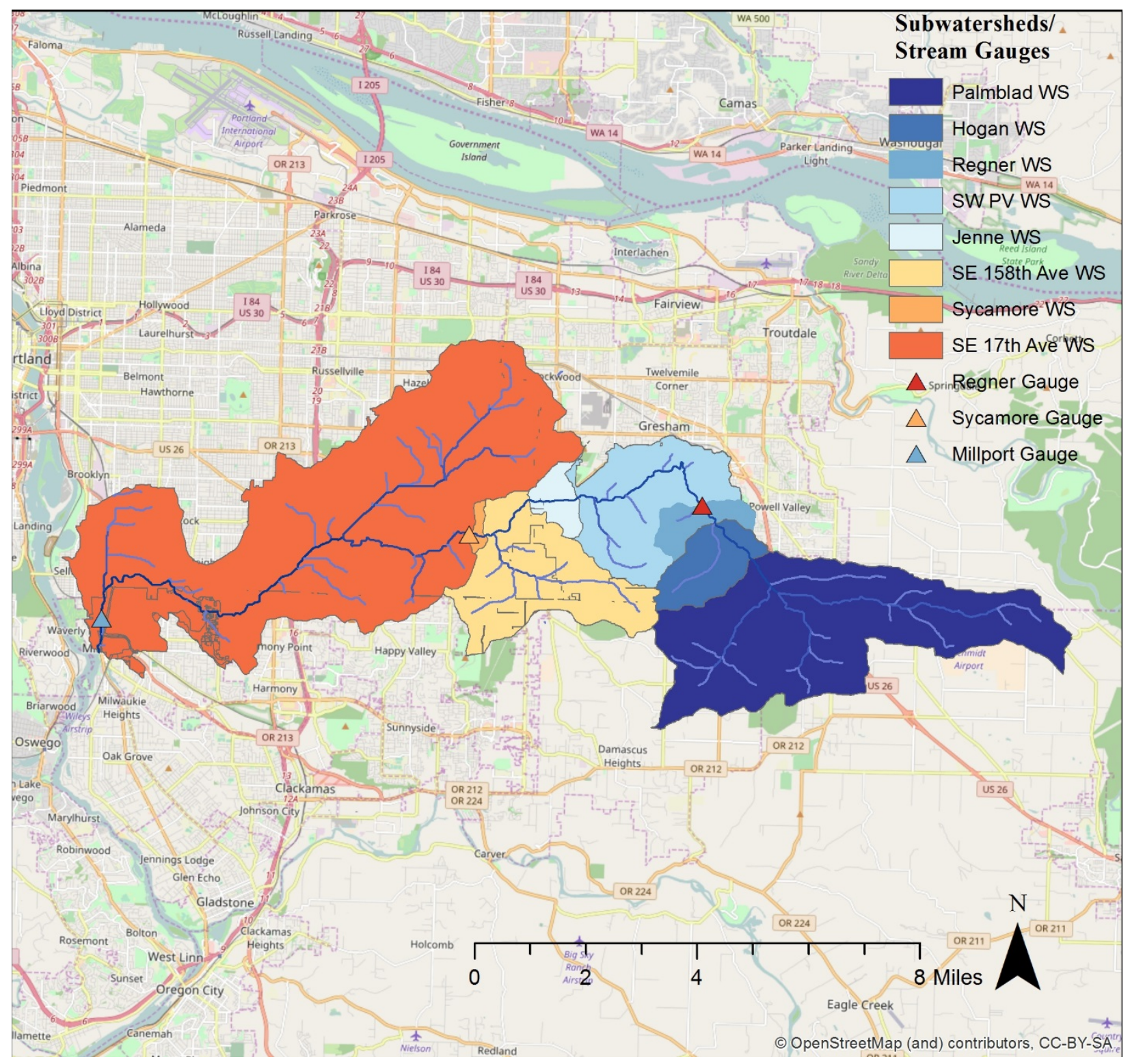

Figure 5. Map of subwatersheds and flow gauges in Johnson Creek used to approximate streamflow for ungauged sites. 
Table 9. Subwatershed areas, gauges and example precipitation values used for approximating streamflow at ungauged sites.

\begin{tabular}{|l|l|l|l|}
\hline Subwatershed (SW) & $\begin{array}{l}\text { Subwatershed Area } \\
\text { (Acres) }\end{array}$ & $\begin{array}{l}\mathbf{2 0 1 5} \text { Annual Precipitation } \\
\text { Example (inches) }\end{array}$ & $\begin{array}{l}\text { Gauge used to estimate } \\
\text { Discharge }\end{array}$ \\
\hline Palmblad & 7992 & 54.93 & Hogan Rd. \\
\hline Hogan Rd. & 9208 & 55.68 & Regner Rd. \\
\hline Regner Rd. & 9812 & 55.67 & $\begin{array}{l}\text { Sycamore from 1/1/1996- } \\
2 / 26 / 1998, \text { then Regner } \\
\text { Gauge installed }\end{array}$ \\
\hline SW Pleasantview Dr. & 12750 & & Regner Rd. \\
\hline Jenne Rd. & 13255 & 54.42 & SW Pleasantview Dr. \\
\hline SE 158 & & 54.28 & Sycamore Gauge \\
\hline Sycamore Rd. & 16716 & 53.63 & Sycamore Gauge \\
\hline SE 17 ${ }^{\text {th }}$ Ave & 16839 & 53.61 & $\begin{array}{l}\text { Millport Rd. (very close } \\
\text { proximity to SE 17 }\end{array}$ \\
\hline
\end{tabular}

\section{Streamflow Calculation}

Equation 1

$\mathrm{Q}_{\text {ungauged }}=\mathrm{Q}_{\text {gauged }} \cdot\left(\frac{\text { SubWatershedAreaungauged }}{\text { SubWatershedArea gauged }}\right) \cdot\left(\frac{\text { Annual Precip ungauged }}{\text { Annual Precip gauged }}\right)$ 


\section{Load Duration Curves}

Load duration curves were constructed using the R version 2.15 R-Forge Project package "tmdl”, which was modified for both aesthetical and technical purposes to include corrected axis, flow regimes, and the $406 \mathrm{cfu} / 100 \mathrm{~mL}$ standard. A load duration model empirically determines flow based loading capacities and can be used to calculate the reductions needed to achieve water quality standards. Load duration curves are equivalent to the product of the water quality standard for a given parameter with the flow duration curve, and as such they provide a simple method to identify hydrologic characteristics of a basin which may then be used to make inferences regarding potential sources of pollutants for different flow regimes (EPA, 2007). Leopold (1994) found that the shape of a flow duration curve provides information about the storage capacity of a basin. In particular, Leopold (1994) found that watershed regions with low storage capacity (high impervious coverage) and flashy runoff behavior exhibited steeply declining slopes either throughout the flow duration curve, or at the high flow end. Conversely, watershed regions influenced by groundwater inputs exhibited either flat slopes throughout the flow duration curve or at the low flow end only.

When applied to E. coli bacteria data, a load duration curve relates the exceedance of the bacterial water quality standard (either the $126 \mathrm{cfu} / 100 \mathrm{~mL}$ geometric mean or $406 \mathrm{cfu} / 100 \mathrm{~mL}$ single sample standard) to a given a flow exceedance interval or "flow regime". In order to determine the progress made towards achieving loading capacity following implementation of TMDL BMPs, a before (1996-2006) and after (2009-2016) load duration model was performed for each of the four study sites: Palmblad Ave, Jenne Rd, SE $158^{\text {th }}$ Ave, and SE $17^{\text {th }}$ Ave. The selection of years to represent the After TMDL category was determined by assessing when TMDL management actions began to occur and by making the assumption that at least a one 
year period would be needed for TMDL management actions to have a noticeable effect on water quality. The City of Gresham, City of Portland, and Multnomah County began implementing their TMDL programs in 2008, (Clackamas County and Milwaukie began in 2009). As a result, 2009-2016 was selected for the After TMDL category.

The flow regimes for the loading duration curves were categorized by exceedance probability: 0-10\% for High Flows, $10-40 \%$ for Transitional Flows, $40-60 \%$ for Typical Flows, $60-90 \%$ for Dry Flows, and $90-100 \%$ for Low Flows. The flow exceedance probabilities associated with streamflow values for each flow regime was determined by ranking flow observations and dividing by the number of events plus one, multiplied by 100 (Equation 2). In order to ensure that flow exceedance probabilities were representative of actual conditions, 10 years of flow data was used for the before (1996-2006 flow data) and after (2006-2016 flow data) load duration curves.

Each of the load duration curves have a boxplot for each flow regime summarizing the median load and spread. The 126 and $406 \mathrm{cfu} / 100 \mathrm{~mL}$ standard lines were constructed separately by taking the product of the respective bacterial standard with each flow value (Load Equation). Load events were derived by taking the product of the bacterial concentration with the flow value for the given day in which the bacterial sample was collected. The average and max reduction needed to reduce event loads below the $126 \mathrm{cfu} / 100 \mathrm{~mL}$ and $406 \mathrm{cfu} / 100 \mathrm{~mL}$ standard respectively, was calculated for each flow regime and overall. Reductions needed for the 126 cfu/100 mL standard were calculated by evaluating the geometric mean of event loads within a given flow regime (current loading), using the most conservative loading capacity within a flow regime (lowest flow), and then applying these values into Equation 3. This method was used in the Willamette Basin TMDL to assess E. coli loading conditions by flow regime, and, therefore, was 
selected as the most appropriate method for this project. Conversely, overall reductions needed to meet the $126 \mathrm{cfu} / 100 \mathrm{~mL}$ standard were assessed using the upper $90^{\text {th }}$ confidence interval method used in the Lower Willamette TMDL (Chapter 5 of the Willamette Basin TMDL). This method fit a regression line to event loads, approximated the upper $90^{\text {th }}$ confidence interval value associated with each load event, evaluated the reduction needed for each load event (using Equation 4 with upper $90^{\text {th }}$ confidence value for a given load event and the associated $126 \mathrm{cfu} / 100$ $\mathrm{mL}$ loading capacity), and took the average of all upper $90^{\text {th }}$ load event reductions needed to represent the total reduction needed.

Two different TMDL calculation methods were used in this project because both the Willamette Basin TMDL and the Lower Willamette TMDL only assess reductions needed overall or by flow regime, but not a combination of both. This project combined both methods to assess reductions needed for individual flow regimes (Willamette Basin method) and overall (Lower Willamette Basin method). Finally, the max loading reduction, which is the reduction needed to bring the highest loading event in a flow interval into compliance with the $406 \mathrm{cfu} / 100$ $\mathrm{mL}$ standard, was determined by using Equation 4 with current loading equal to the highest load event in an interval and the loading capacity as the $406 \mathrm{cfu} / 100 \mathrm{~mL}$ standard corresponding to the max load event within a flow interval (DEQ, 2016).

Equation 2

$$
\text { Flow Exceedance Probability }=\left(\frac{\text { Rank }}{n+1}\right) * 100
$$

Equation 3

$$
\text { Loading Capacity } \frac{\mathrm{Col}}{\mathrm{Day}}=(126 \text { or } 406) \frac{\mathrm{Col}}{100 \mathrm{~mL}} * \mathrm{Q} \frac{\mathrm{Ft}^{3}}{\mathrm{~s}} * 283.2 \frac{100 \mathrm{~mL}}{\mathrm{Ft}^{3}} * 86400 \frac{\mathrm{s}}{\mathrm{Day}}
$$

Equation 4

$$
\% \text { Reduction }=1-\left(\frac{\text { Loading Capacity }}{\text { Current Loading }}\right) * 100
$$


Table 10. Calculating the TMDL by flow regime

\begin{tabular}{|l|l|}
\hline & Flow Regime \\
\hline Loading Capacity (LC) & 1 \\
\hline Current Loading & Loading at lowest flow value for each flow regime \\
\hline$\%$ reduction needed & Log mean of daily load events within flow regime \\
\hline TMDL $^{1}$ & $=1$-(TMDL / Current Loading) $* 100$ \\
\hline
\end{tabular}

1. Calculation methods from (ODEQ, 2006) 


\section{Pollutant Loading Reduction Evaluation}

\section{Background}

To evaluate the progress that NPDES (MS4) agencies were making towards required pollutant loading reductions, DEQ required the use of a pollutant load reduction empirical model by each agency as a part of the permit process. City of Portland, City of Gresham, and Multnomah County were required to submit a report of the load reduction model results to DEQ by November 1, 2014. While Clackamas County and Co-permitees: Milwaukie and Happy Valley, were required to submit their results to DEQ by November 1, 2015. The model requirements established by DEQ were that pollutant loading was to be evaluated with and without BMPs, and a determination was to be made regarding pollutant loading reductions attributed to BMPs. All agencies utilized a GIS land use loading based model, following the EPA Simple Method (Schueler, 1987) , which requires the following parameters: annual precipitation, impervious cover for a given land use, E. coli. storm runoff concentration for a given land use, precipitation data, and the area of each land use type.

The model determined E. coli loading to the stream by utilizing impervious cover and event mean storm runoff $E$. coli concentrations for general land use zoning categories including: single family-residential, multi family-residential, commercial, industrial, open space/undeveloped, and agricultural. DEQ requested that Phase I MS4 agencies coordinate to utilize consistent data inputs. As a result, all of the Phase I MS4s including: Clackamas (includes Happy Valley) and Multnomah County, City of Portland, City of Milwaukie, and City of Gresham utilized Oregon Association of Clean Water Agencies (ACWA) data for impervious surface values and event mean concentrations (EMC) for E. coli storm runoff. Land use EMCs 
were collected collectively for ACWA from land use based outfalls within each of the Phase I jurisdictions in Oregon (Portland, Gresham, CWS, Eugene) and the impervious cover values were selected by each jurisdiction based on the best available data (often from stormwater master plans that were done specifically for each jurisdiction). Effluent concentrations and/ or flow reduction for several categories of structural BMPs were predominately from a memo by Geosyntec Consultants (Strecker, 2005) that summarized findings from the national EPA BMP database. However, the data were not adequate to evaluate the treatment or flow reduction of all major stormwater treatment facilities being utilized within the watershed. Therefore, additional studies were conducted by Clean Water Services and City of Portland to determine localized effluent pollutant concentrations and volume reduction for swales and wet ponds (City of Gresham, 2014).

The finalized BMP treatment and flow reduction values compiled from the previously mentioned studies can be found in Table 12. The models used by each of the MS4 agencies only accounted for structural BMPs, nonstructural BMPs were not included. While the importance of implementing nonstructural practices is widely acknowledge, the effectiveness of these strategies is largely unknown.

Although methods exist for approximating load reductions for nonstructural source control practices such as septic system removal, cross connection removal, and livestock exclusion (Culvert et al., 2002), the qualitative nature of educational outreach activities has proven difficult in translating to quantitative load reductions. Furthermore, literature that addresses educational outreach activities rely on professional judgement to determine a loading reduction. Gray et al. (2015) found methods for determining loading reductions from educational outreach to be nonexistent; they attempted to determine bacterial load reductions attributed to educating pet 
owners by compiling sociological studies and surveys. Bamberg and Moser (2007) conducted a sociological study to assess correlations among environmental attitude, guilt, moral obligation, behavior, and awareness. The study found that $18 \%$ of behavior change can be explained by increasing awareness of a problem. Using these findings, Gray et al. (2015) applied $18 \%$ as the maximum theoretical bacterial reduction possible for education outreach. However, because other educational activities not related to municipal strategies could influence behavior, a three by three matrix with different levels of influence of pet waste pick up outreach was constructed. The table contained the following columns: entirely responsible (100\%), largely responsible (66\%), and partially responsible (33\%), followed by three rows with expected removal: (90\%), (60\%), and (30\%). Each of these combinations were multipied by the maximum reduction factor attributed to education (0.18). The results found that pet waste outreach could reduce bacterial loading from pet waste by $3.6 \%$ to $10.7 \%$. Although this method did not directly measure loading reductions, it could be beneficial for municipalities to account for educational outreach loading reductions until better methods are available.

\section{Model Used}

Pollutant loading reduction evaluations were reassessed in this paper for each of the NPDES MS4 agencies, with the exception of Multnomah County due to its' negligible MS4 coverage (Multnomah County, 2014). The overall objective of the pollutant reduction models were to determine the percent reduction of $E$. coli loading attributed to implementation of stormwater BMPs. The model used in this paper was slightly adjusted from the models previously used by MS4 agencies within the watershed. Modifications included: spatially averaged annual precipitation for each zoning category (rather than one value for an entire area), spatially 
averaged impervious surface percentage for each zoning category, and incorporation of both flow reduction and treatment effects rather than one or the other (Figure 6).

Annual precipitation data was extracted from Oregon State University’s PRISM Climate Data and impervious surface values were extracted from the 2011 National Land Cover Database (NLCD). PRISM annual precipitation data (2015) and NLCD data (2011) were spatially averaged for each zoning category and input into Equation 5 and Equation 6 to determine total pollutant loading (without treatment) for each MS4 agency. Non-MS4 regions within the watershed were not modeled as a majority of these areas have been shown to be hydrologically disconnected from the stream (BES, 2005). Flow and/or effluent reductions attributed to structural BMPs were determined by evaluating the area of intersection for a given zoning category and structural BMP. Structural BMPs were only used in the model if effluent $E$. coli concentrations from a facility were lower than the untreated runoff from the land use category that facility is intersecting (Table 11 and Table 12). If however, the $E$. coli effluent concentration of a treatment facility was greater than the untreated runoff from the zoning category it is intersecting, but the facility had an associated flow reduction, than only the flow reduction would be applied in the model. Further, if applicable both flow and effluent reductions were applied to pollutant loads (Figure 6). Unfortunately, with the exception of City of Gresham, BMP data did not allow for the effects of pollutant loads treated in series to be accounted for. Additionally, the impacts of nonstructural BMPs on pollutant loads could not be determined due to difficulties associated with translating qualitative data into numerical load reductions. 


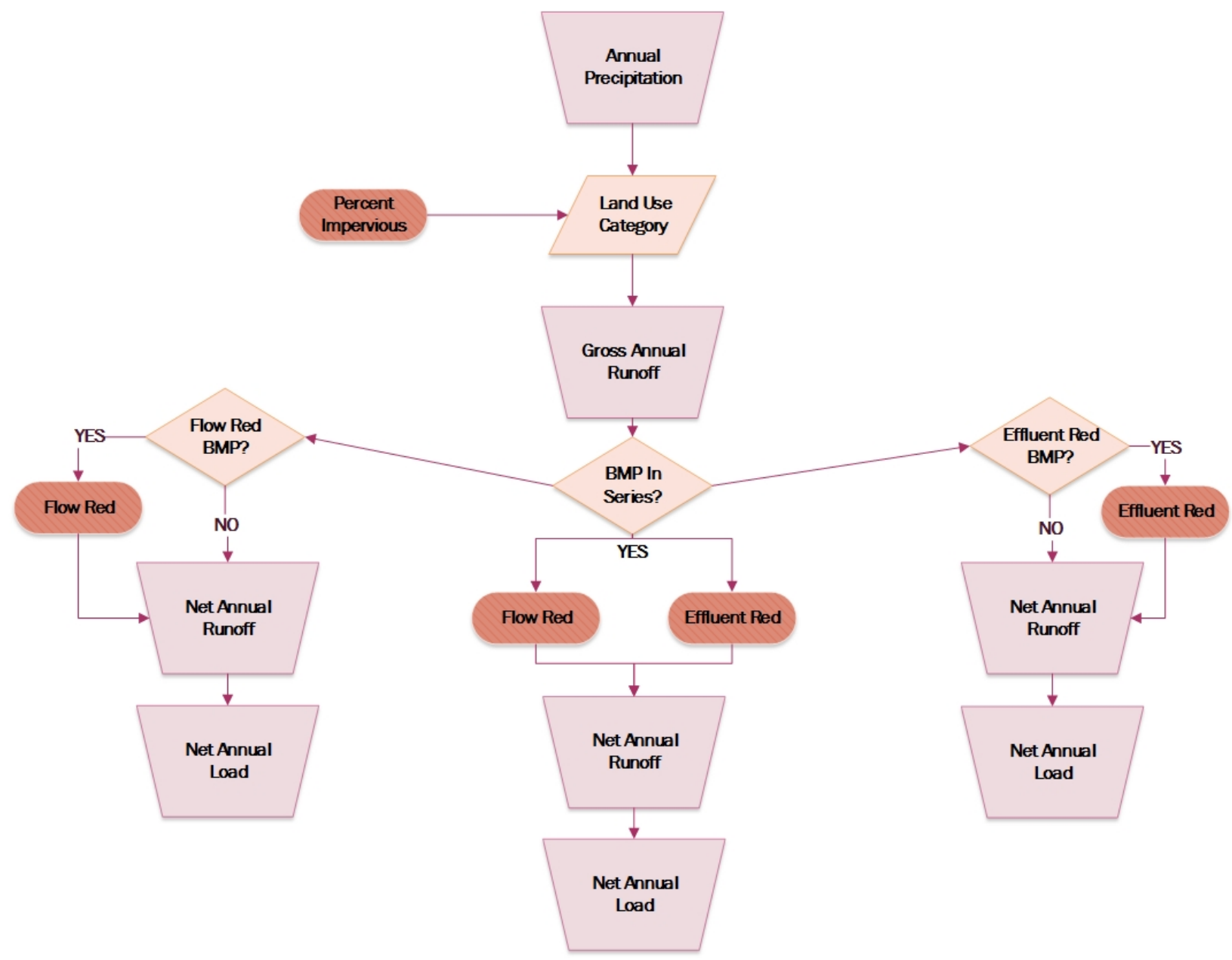

Figure 6. Conceptual flow diagram illustrating process used for GIS pollutant load reduction model based off of the EPA Simple Method.

Note: Red= Reduction 


\section{Land Use Loading}

The spreadsheet model for estimating bacterial loading due to runoff events is based on the EPA Simple Method (Schueler 1987), which is commonly used for estimating pollutant loads for urban land uses. The equations that were used to calculate bacterial loads and associated reductions due to structural BMPs are:

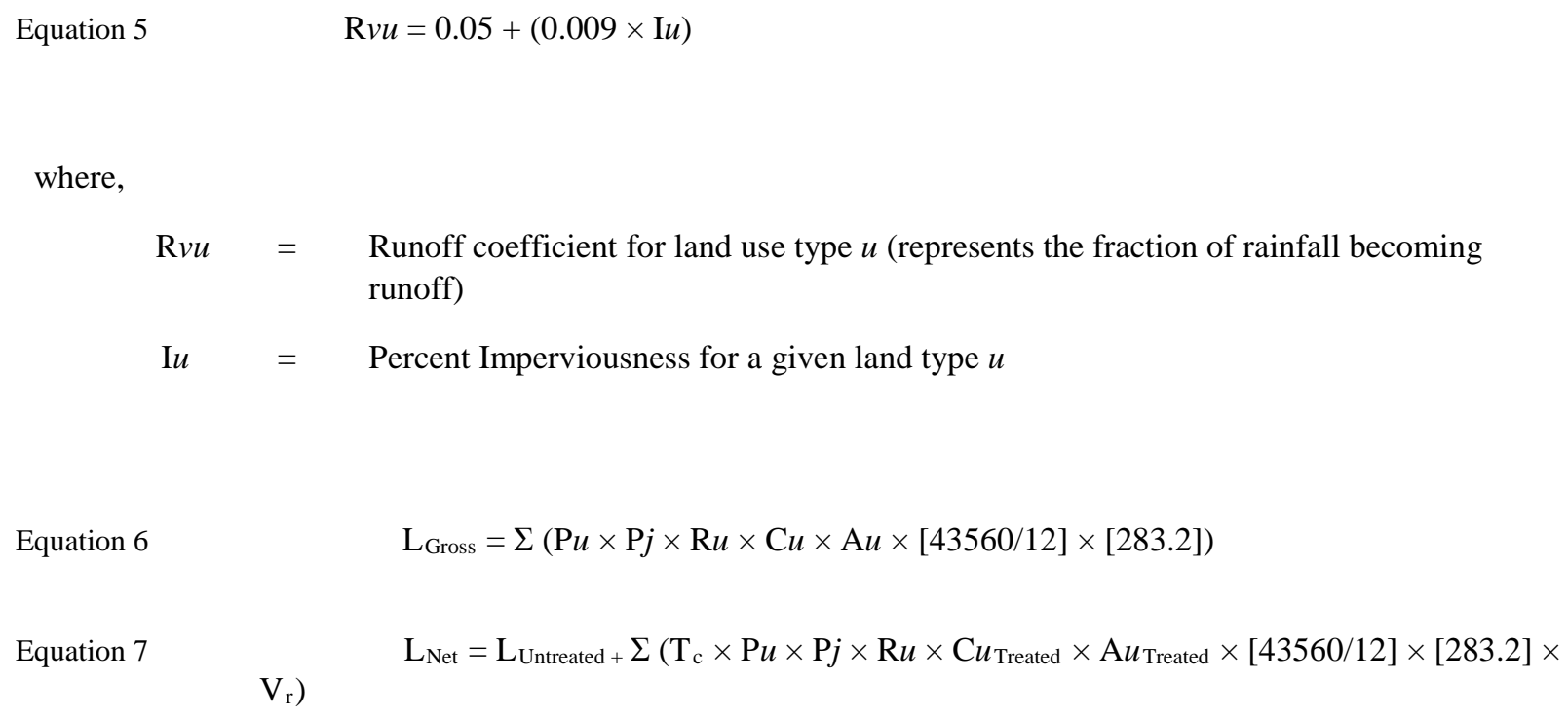

where,

\begin{tabular}{|c|c|c|}
\hline L Gross & $=$ & Total pollutant load for all land use types in watershed without BMPs, $u$ (colonies/year) \\
\hline $\mathrm{L}_{\mathrm{Net}}$ & $=$ & Total pollutant load for all land use types in watershed with BMPs, $u$ (colonies/year) \\
\hline $\mathrm{Pu}$ & $=$ & Precipitation for a given land type $u$ (inches/year) \\
\hline $\mathrm{Pj}$ & $=$ & $\begin{array}{l}\text { Ratio of storms producing runoff (assume } 0.9 \text {, since this accounts for evaporation and } \\
\text { other losses) }\end{array}$ \\
\hline $\mathrm{Ru}$ & $=$ & Runoff coefficient for land use type $u$ (fraction of rainfall becoming runoff) \\
\hline $\mathrm{T}_{\mathrm{C}}$ & $=$ & $\begin{array}{l}\text { Percent design capacity of annual precipitation serviced by detention type facilities } \\
\text { (expressed as a decimal) }\end{array}$ \\
\hline $\mathrm{V}_{\mathrm{r}}$ & $=$ & Percent volume reduction from stormwater facilities (expressed as a decimal) \\
\hline $\mathrm{Cu}$ & $=$ & Event Mean Concentration (EMC) for land use type $u$ (\# E. coli colonies/ 100 mL) \\
\hline $\mathrm{A} u$ & $=$ & Area of land use type $u$ (acres) \\
\hline
\end{tabular}


Equation $8 \quad$ \% Load Reduction= 1- $\left(\frac{\text { Total Net Annual Load }}{\text { Total Gross Annual Load }}\right)$

Table 11. Land use event mean runoff concentrations for E. coli used in EPA Simple Method GIS model

\begin{tabular}{|l|c|c|c|c|}
\hline \multirow{4}{*}{ Pollutant } & \multirow{3}{*}{ Land Use } & \multicolumn{3}{|c|}{ Land Use EMCs } \\
\cline { 2 - 5 } & & $\begin{array}{c}\text { 95\% Lower Conf } \\
\text { Interval }\end{array}$ & Geomean & $\begin{array}{c}\text { 95\% Upper Conf } \\
\text { Interval }\end{array}$ \\
\hline \multirow{3}{*}{ E. coli } & Agriculture & 573 & 1247 & 2409 \\
\cline { 2 - 5 } & Industrial & 154 & 438 & 1004 \\
\cline { 2 - 5 } & Open Space & 57 & 87 & 124 \\
\cline { 2 - 5 } & Undeveloped & 57 & 87 & 124 \\
\cline { 2 - 5 } & Commercial & 573 & 1247 & 2409 \\
\cline { 2 - 5 } & Residential & 970 & 1656 & 2651 \\
\cline { 2 - 5 } & Multi Family Res & 970 & & 2651 \\
\hline
\end{tabular}

Table 12. Flow reduction and removal efficiency values for structural bmp categories used in GIS model.

\begin{tabular}{|c|c|c|c|c|c|c|c|c|}
\hline Parameter & Units & $\begin{array}{c}\text { Centrifugal } \\
\text { Separator } \\
\text { Hydrodynamic } \\
\text { Devices } \\
\end{array}$ & $\begin{array}{c}\text { Filters } \\
\text { (Leaf/Sand/ } \\
\text { Other) }\end{array}$ & $\begin{array}{l}\text { Ponds, Dry } \\
\text { Vegetated } \\
\text { Detention } \\
\text { Pond* } \\
\end{array}$ & $\begin{array}{l}\text { Ponds, } \\
\text { Wet } \\
\text { Retention } \\
\text { Basin } \\
\end{array}$ & $\begin{array}{l}\text { Swales, } \\
\text { Vegetated } \\
\text { Filter } \\
\text { Strips } \\
\end{array}$ & $\begin{array}{c}\text { Wetlands, } \\
\text { Constructed } \\
\text { Surface Flow }\end{array}$ & $\begin{array}{l}\text { Sedi } \\
\text { ment } \\
\text { Man } \\
\text { hole }\end{array}$ \\
\hline E. coli & MPN/100mL & 3634 & 79 & 1922 & 321 & 1820 & 499 & 5587 \\
\hline $\begin{array}{l}\text { Flow } \\
\text { Reduction }\end{array}$ & $\%$ & $0 \%$ & $0 \%$ & $23 \%$ & $5 \%$ & $29 \%$ & $5 \%$ & $0 \%$ \\
\hline
\end{tabular}

NOTES:

Values in BLACK are from the ACWA Rangers memo (2005)

Values in RED are from the City of Portland (2008) reanalysis of BMP effectiveness

1. Dry pond BOD values based on wet pond BOD values

2. Dry pond E. coli numbers values on wet pond E. coli values

3. Sediment manhole BOD values based on hydrodynamic devices BOD values 


\section{Data Preparation}

Prior to performing any land use loading calculations for the Cities of Gresham, Portland, and Milwaukie, a modest amount of data preparation was performed. The overall objective of the data preparation process was to obtain a land use zoning layer for each of the City’s MS4 boundaries, to demarcate structural BMPs that intersect MS4 boundaries of each city, to determine the impervious percentages of different land use categories within each City’s MS4 boundary, and to determine the average annual precipitation for each land use category within each City’s MS4 boundary. MS4 boundary shapefiles for each of the cities were projected to NAD_1983_2011_Oregon_Statewide_Lambert (meters) and clipped to the Johnson Creek watershed. The MS4 areas for each city was cross validated with Pollutant Load Reduction Evaluation Reports for each city to ensure accuracy (City of Gresham, 2014), (City of Portland, 2014), and (City of Milwaukie, 2016) . Land use categories did not require any reclassification for City of Gresham and Milwaukie as they already consisted of ACWA land use categories, however, City of Portland RLIS land use zoning categories were reclassified into ACWA categories using the City of Gresham (2014) benchmark document. Impervious surface percentages and annual precipitation values for each of the land use categories were determined for MS4 boundaries using the ArcGIS zonal statistics toolkit. 


\section{BMPs Used in Model}

BMP shapefiles were obtained from City of Gresham, City of Portland, and City of Milwaukie. Using the pairwise intersect tool in ArcGIS, BMP treated areas were determined for each ACWA land use zoning category; this was performed for the MS4 regions for City of Gresham, City of Portland, and City of Milwaukie. For BMP treated areas, the types of facilities and their respective coverage for a given land use zoning category were needed to determine overall loading reductions. Using the select by attribute tool and summary statistics in ArcGIS, the coverage of different facilities was determined for each land use zoning category in a given MS4. Common structural BMP facilities used in the models included: swales, filters, dry detention ponds, wet retention ponds, raingardens, and porous pavement (Table 36). Difficulties were encountered with the shapefile used for City of Portland BMPs. More specifically, numerous treated areas had overlaps in the coverage area for different structural BMP facility types; this caused duplicates for treated area values in these regions. Discussion with City of Portland revealed that overlaps of BMP facility types for a given area were attributed to script generated delineation of BMP treated areas (rather than manual delineation). To partially remedy this issue, duplicate area values were removed and swales were selected as the most representative BMP facility type for overlapping regions due to their wide scale coverage in nonoverlapping regions. Due to the complications mentioned, it should be noted that the pollutant loading reduction model for City of Portland may or may not be representative of actual loading reductions. 


\section{Model Calculations}

Percent loading reductions for E. coli attributed to stormwater BMPs were determined for each MS4 agency by evaluating loading with and without structural BMPs. The calculations for loading without BMPs (gross loading) as previously discussed, is a straightforward process requiring only land use based EMC values for E. coli and spatially averaged precipitation/ percent impervious surfaces for a given land use (Equation 6). Determination of net loading, which incorporates both treated and non-treated land uses, however, is a more involved process. Net loading calculations (Equation 7) required all parameters needed for gross loading but additionally required the following factors: annual percent design treatment capacity, percent volume reduction from BMPs (Table 12), and/or treated effluent E. coli concentrations (Table 12). The annual design treatment capacity values used for City of Gresham, City of Portland, and City of Milwaukie, were 0.8, 0.9, and 0.8 respectively (City of Gresham, 2014; City of Portland, 2016; City of Milwaukie, 2016). Volume and/or effluent reductions were determined by assessing the area of each land use treated by a given facility type and matching the values in (Table 12) with the appropriate facility type. In the case that several types of facilities treated a given land use, areas treated by each respective facility type, percent volume reduction for each facility type, and/ or effluent concentrations for each facility type were arranged as vector data when input into Equation 7. Finally, to determine the percent loading reduction attributed to structural BMPs, gross and net loading values for each MS4 agency were input into Equation 8. 


\section{Clackamas County Service District \#1}

No pollutant loading reduction model was performed for Clackamas County Service District\#1 (CCSD\#1, including Happy Valley) as the files needed to delineate both their MS4 and treated areas within the watershed could not be obtained. Therefore, the results from CCSD\#1 2015 pollutant load reduction evaluation report are presented in lieu of another model. While modeling results for the other MS4 agencies within the watershed provides both individual land use loading contributions and total land use loading, the CCSD\#1 report only reports total loading, and therefore, that is what is reported. 


\section{Population}

Oregon State Census data for the years 2000, and 2010, were obtained from the U.S Census Bureau: https://www.census.gov/geo/maps-data/data/tiger-line.html, and joined with corresponding census blocks for Multnomah and Clackamas County, from American Fact Finder: https://factfinder.census.gov/faces/nav/jsf/pages/index.xhtml in ArcGIS. Census data associated with census blocks for 1990, was removed from both the U.S Census Bureau website and American Fact Finder and were instead obtained from the National Historic Geographical Information Systems (NHGIS) website: https://data2.nhgis.org. Once census blocks for all years were obtained and joined with corresponding population data, they were then clipped to the Johnson Creek Watershed.

Population data for each of the cities and counties within the watershed for 1990, 2000, and 2010, were determined using the select by location tool in ArcGIS. Census blocks (clipped to the watershed) for a given year were selected as the target feature and city or county boundary (county boundary excludes city jurisdictional boundaries) shapefiles obtained from metro (clipped to the watershed): http://rlisdiscovery.oregonmetro.gov/ were selected as the source layer. Census blocks were selected if their centroid was located within a given source layer (city or county shapefile clipped to the watershed). Based off of visual inspection this method most accurately selected census blocks for each of the cities and counties within the watershed. The census blocks selected appeared to completely coincide with each of the city or county boundaries, as opposed to other selection methods which either selected blocks surpassing city or county boundaries, or selected only a subset of blocks with a city or county boundary.

Once the appropriate census blocks were selected for a given city or county and a given year, the statistics toolbar was used to find the summation of census blocks within the watershed 
city or county of interest. Finally, the total watershed population for a given census year was determined by taking the summation of city and county populations within the watershed.

\section{Land Cover}

NLCD and RLIS land use layers were clipped to the watershed using the extract by mask tool from the ArcGIS Extraction Toolbox, projected to NAD 1983 (2011) Oregon Statewide Lambert (Meters), and converted from a raster to a polygon featureclass. Using the select by attributes tool, percent land cover was calculated for each land use category for both the 2011 NLCD land use layer and the 2016 RLIS land use layer. Due to the lack of detailed urban land use classifications provided by NLCD data, RLIS data was selected for analysis of urban areas, while NLCD data was used to categorize natural areas (forest, wetlands, grasslands). 


\section{Designated Management Agency Implementation}

\section{Multnomah County}

\section{NPDES (MS4) Background}

Multnomah County contains both urban and rural land uses. Increases in city jurisdiction within urban areas of Portland and Gresham in recent years have dramatically decreased County jurisdiction in urban areas (Multnomah County, 2008). The county maintains responsibility over four pockets of land in rural and agricultural areas adjacent to the City of Portland (Figure 7). These pockets of land were required to obtain an MS4 permit as they are considered to be a part of the Portland Urban Service Area. However, discharge from these areas is unlikely to reach the stream (Multnomah County, 2014) and stormwater management strategies are limited. Therefore, only TMDL activities for Multnomah County will be reviewed in this document.

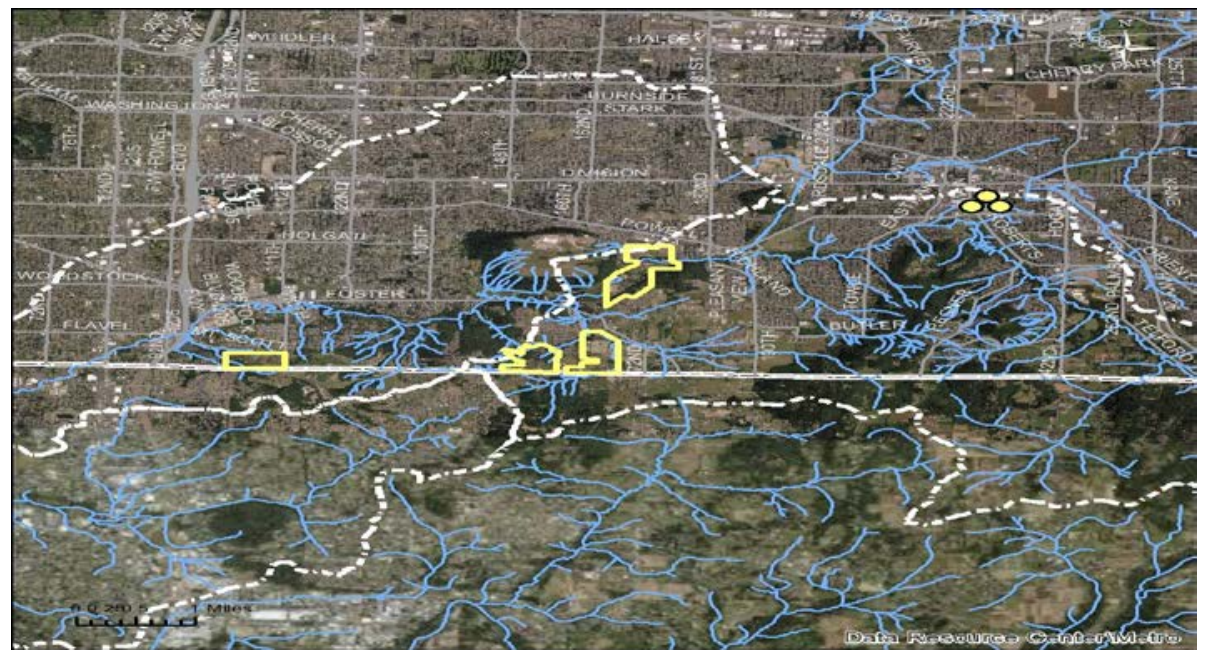

Figure 7. Multnomah County Johnson Creek MS4 boundaries. The entirety of the MS4s owned and operated by Multnomah County within the watershed fall within the City of Portland (Multnomah County, 2014). 


\section{TMDL Implementation Plan Background}

The County has jurisdiction over rural areas within the upper Johnson Creek watershed with the exception of forested and agricultural land use types, both of which are the responsibility of the Oregon Department of Forestry (ODF) and Oregon Department of Agriculture (ODA), respectively. Failing septic systems and illicit dumping of waste, pet waste, and livestock manure were identified in the County's 2008 TMDL implementation plan as major sources of bacterial discharge to surface waters in the upper Johnson Creek watershed (Multnomah County, 2008).

The County takes proactive and reactive approaches to address its TMDL responsibilities. Proactive activities include partnering with the local Soil and Water Conservation District (SWCD) to develop educational materials for the public on septic system maintenance and the proper disposal of pet waste. The reactive activities include investigating illegal dumping of waste and failing septic systems. The county has received funding from ODA for monitoring efforts and has partnered with the City of Gresham to collect data for reach scale investigations in Johnson Creek. The reach scale investigations provide baseline data to help distinguish possible occurrences of bacterial discharges. Discharges suspected from activities on agricultural land are reported to ODA for enforcement. The county contracts with the City of Portland Bureau of Development Services Sanitarian to provide inspection services in areas identified by reach scale investigations as susceptible to septic system failures. Coordination with County Road Maintenance crews occurs to identify illicit dumping of waste. Residents suspected of dumping waste illicitly will receive a warning, followed by a citation from the County Code Enforcement for repeat offences. Similarly, homeowners may receive a notice of violation and subsequent citations if failing septic systems are not addressed in the timeframe set during an 
inspection; enforcement of septic systems however, is not the responsibility of the County and is carried out by the City of Portland.

\section{TMDL Activities}

The County’s primary strategies to mitigate bacterial discharge include in-stream monitoring, coordinating with ODA and City of Portland to address suspected agricultural discharge violations and septic discharge violations, respectively, and educational outreach to pet owners. The status of strategies implemented from 2009-2015, described in the County's TMDL Implementation 5 year review for 2009-2013, and TMDL annual reports for 2013-2014, and 2014-2015, are shown in the table below (Table 13 and Table 14).

Table 13. Summary of Multnomah County TMDL Implementation 5 year review (2009-2013)

\begin{tabular}{|c|c|c|c|c|}
\hline SOURCE & STRATEGY & HOW & STATUS & SUMMARY \\
\hline Pet Wastes & Educate pet owners & $\begin{array}{l}\text { Partner with local Soil \& } \\
\text { Water Conservation Districts } \\
\text { to develop and disseminate } \\
\text { educational materials }\end{array}$ & $\begin{array}{l}\text { ONGOING: } \\
\text { SWCD outreach } \\
\text { materials are } \\
\text { provided at the } \\
\text { County Planning } \\
\text { office. }\end{array}$ & $\begin{array}{l}\text { Approximately } 100 \\
\text { brochures taken in } \\
\text { a given year. }\end{array}$ \\
\hline Illegal Dumping & $\begin{array}{l}\text { Enforce Solid Waste } \\
\text { Nuisance ordinance }\end{array}$ & $\begin{array}{l}\text { Report all illegal dumping to } \\
\text { County nuisance code } \\
\text { enforcement }\end{array}$ & $\begin{array}{l}\text { ONGOING: } \\
\text { The County } \\
\text { Nuisance } \\
\text { Enforcement } \\
\text { encountered one } \\
\text { minor incident } \\
\text { involving human } \\
\text { feces not related to } \\
\text { the stream. }\end{array}$ & $\begin{array}{l}\text { Illegal dumping is } \\
\text { very rarely related } \\
\text { to bacteria in the } \\
\text { stream. }\end{array}$ \\
\hline $\begin{array}{l}\text { Failing Septic } \\
\text { Systems }\end{array}$ & $\begin{array}{l}\text { Conduct reach scale } \\
\text { investigation in } \\
\text { Johnson Creek }\end{array}$ & $\begin{array}{l}\text { Follow the Agricultural Water } \\
\text { Quality Plan baseline } \\
\text { sampling (2007-2008) with } \\
\text { analysis and additional } \\
\text { investigative monitoring }\end{array}$ & $\begin{array}{l}\text { REPLACED: } \\
\text { DEQ supported } \\
\text { JCWC and IJC with } \\
\text { a } 319 \text { grant in 2012- } \\
13 \text { for source ID }\end{array}$ & NA \\
\hline
\end{tabular}




\begin{tabular}{|c|c|c|c|c|}
\hline & $\begin{array}{l}\text { Inspect septic systems } \\
\text { suspected of failure }\end{array}$ & $\begin{array}{l}\text { County contracts with City of } \\
\text { Portland Bureau of } \\
\text { Development Services } \\
\text { sanitarian to provide } \\
\text { inspection services }\end{array}$ & $\begin{array}{l}\text { ONGOING: } \\
\text { One notice of } \\
\text { violation was issued } \\
\text { by Portland BDS } \\
\text { based on County } \\
\text { analysis }\end{array}$ & $\begin{array}{l}\text { Difficult to } \\
\text { determine where } \\
\text { failing septic } \\
\text { systems occur even } \\
\text { with WQ data and } \\
\text { DNA analysis }\end{array}$ \\
\hline & $\begin{array}{l}\text { Educate homeowners } \\
\text { about septic system } \\
\text { maintenance }\end{array}$ & $\begin{array}{l}\text { Partner with East Multnomah } \\
\text { Soil \& Water Conservation } \\
\text { District (EMSWCD) to } \\
\text { develop and disseminate } \\
\text { educational materials }\end{array}$ & $\begin{array}{l}\text { ONGOING: } \\
\text { SWCD outreach } \\
\text { materials for } \\
\text { Johnson Creek and } \\
\text { Beaver Creek are } \\
\text { provided at the } \\
\text { County Planning } \\
\text { office. }\end{array}$ & $\begin{array}{l}\text { Approximately } 100 \\
\text { brochures taken in } \\
\text { a given year. }\end{array}$ \\
\hline $\begin{array}{l}\text { Non-point source } \\
\text { from agricultural } \\
\text { land }\end{array}$ & $\begin{array}{l}\text { Conduct reach scale } \\
\text { investigations based on } \\
\text { TMDL study }\end{array}$ & $\begin{array}{l}\text { Follow the Agricultural Water } \\
\text { Quality Plan baseline } \\
\text { sampling (2007-2008) with } \\
\text { analysis and additional } \\
\text { investigative monitoring. }\end{array}$ & $\begin{array}{l}\text { REPLACED: } \\
\text { EMSWCD received } \\
\text { funds from ODA to } \\
\text { conduct reach scale } \\
\text { monitoring in the } \\
\text { agricultural areas. }\end{array}$ & NA \\
\hline & $\begin{array}{l}\text { Address runoff issues } \\
\text { via Agricultural Water } \\
\text { Quality Plans }\end{array}$ & $\begin{array}{l}\text { Notify local Soil \& Water } \\
\text { Conservation Districts when } \\
\text { problems are identified, or } \\
\text { notify ODA for enforcement }\end{array}$ & $\begin{array}{l}\text { ONGOING: } \\
\text { One livestock } \\
\text { bacteria related } \\
\text { complaint was } \\
\text { submitted to the } \\
\text { ODA Water Quality } \\
\text { Complaint program. }\end{array}$ & $\begin{array}{l}\text { Strategy is } \\
\text { opportunistic as } \\
\text { the County has no } \\
\text { jurisdictional } \\
\text { authority here }\end{array}$ \\
\hline
\end{tabular}

Acronyms in Table:

1. $\quad$ Bureau of Development Services (BDS)

2. East Multnomah County Soil \& Water Conservation District (EMSWCD)

3. Interjurisdictional Committee (IJC)

4. Johnson Creek Watershed Council (JCWC) 
Table 14. Summary of Multnomah County TMDL Implementation for 2015 and 2016. Multnomah County’s TMDL Implementation Plan was updated in 2014 as a part of the 2009-2013 review process.

\begin{tabular}{|c|c|c|c|c|c|}
\hline SOURCE & STRATEGY & HOW & MEASURE & TIMELINE & STATUS \\
\hline \begin{tabular}{|l|} 
Pet Wastes \\
\end{tabular} & Educate pet owners & $\begin{array}{l}\text { Partner with local } \\
\text { SWCDs to develop/ } \\
\text { disseminate educational } \\
\text { materials }\end{array}$ & Ongoing Program & None & $\begin{array}{l}\text { No Reporting } \\
\text { measures }\end{array}$ \\
\hline Illegal Dumping & $\begin{array}{l}\text { Enforce Solid Waste } \\
\text { Nuisance ordinance }\end{array}$ & $\begin{array}{l}\text { Report all illegal } \\
\text { dumping to County } \\
\text { nuisance code } \\
\text { enforcement }\end{array}$ & Ongoing Program & None & $\begin{array}{l}\text { 2013-2014: NA } \\
\text { 2014-2015: Two } \\
\text { reports of illegal } \\
\text { dumping in Kelley } \\
\text { Creek, investigation } \\
\text { found no water } \\
\text { quality concerns. } \\
\text { 2015-2016: No } \\
\text { reports of fecal } \\
\text { dumping. }\end{array}$ \\
\hline \multirow[t]{2}{*}{$\begin{array}{l}\text { Failing Septic } \\
\text { Systems }\end{array}$} & $\begin{array}{l}\text { Inspect County } \\
\text { drainage system for } \\
\text { septage }\end{array}$ & $\begin{array}{l}\text { Identify areas with } \\
\text { suspicious } \\
\text { contaminants or septage } \\
\text { in ditches and catch } \\
\text { basins during road } \\
\text { maintenance activities }\end{array}$ & Ongoing Program & None & $\begin{array}{l}\text { 2013-2014: NA } \\
\text { 2014-2015: } 1 \text { report } \\
\text { of suspected septage } \\
\text { at Barbara Welch Rd } \\
\text { (Kelley Cr), low } \\
\text { bacterial counts } \\
\text { however, indicate no } \\
\text { septic issues. } \\
\text { 2015-2016: No } \\
\text { suspected septic } \\
\text { issues. }\end{array}$ \\
\hline & $\begin{array}{l}\text { Educate homeowners } \\
\text { about septic system } \\
\text { maintenance }\end{array}$ & $\begin{array}{l}\text { Partner with EMSWCD } \\
\text { to develop/disseminate } \\
\text { educational materials }\end{array}$ & Ongoing Program & None & $\begin{array}{l}\text { No reporting } \\
\text { measures }\end{array}$ \\
\hline $\begin{array}{l}\text { Instream } \\
\text { Monitoring }\end{array}$ & $\begin{array}{l}\text { Identify stream reaches } \\
\text { with the highest } \\
\text { concentrations of } E \text {. } \\
\text { coli }\end{array}$ & $\begin{array}{l}\text { Review instream E. coli } \\
\text { data from collaborative } \\
\text { monitoring efforts. }\end{array}$ & $\begin{array}{l}\text { Coordinate with } \\
\text { Johnson Creek } \\
\text { interjurisdictional } \\
\text { committee }\end{array}$ & Ad hoc sampling & $\begin{array}{l}\text { 2013-2014: NA } \\
\text { 2014-2015: Jenne Cr } \\
\text { identified as having } \\
\text { high bacterial } \\
\text { concentrations. } \\
\text { 2015-2016: NA }\end{array}$ \\
\hline $\begin{array}{l}\text { Livestock } \\
\text { Manure }\end{array}$ & $\begin{array}{l}\text { Address runoff issues } \\
\text { via Agricultural Water } \\
\text { Quality Plans }\end{array}$ & $\begin{array}{l}\text { Submit Water Quality } \\
\text { Complaint Form to } \\
\text { ODA }\end{array}$ & Report as needed & None & $\begin{array}{l}\text { 2013-2014: NA } \\
\text { 2014-2015: No } \\
\text { livestock related } \\
\text { reports received. } \\
\text { 2015-2016: No } \\
\text { livestock related } \\
\text { reports received. }\end{array}$ \\
\hline
\end{tabular}




\section{City of Portland}

The City of Portland is the largest city in the state of Oregon, covering approximately 145 square miles with an estimated population of 639,863 as of 2016. The city is located in the Willamette Valley at the confluence of the Columbia and Willamette Rivers. The City of Portland was listed as a DMA by ODEQ in the 2006 Bacteria TMDL for Johnson Creek. The city is responsible for managing bacterial point and non-point discharges to the stream by adopting a SWMP to address point sources as required by their NPDES (MS4) permit and a TMDL Implementation Plan to address non-point sources.

\section{NPDES (MS4) Background}

In response to the 1990 EPA stormwater rule, DEQ required that Phase I MS4s develop a SWMP and obtain an NPDES (MS4) permit. The City developed a SWMP in 1993 and was issued its first MS4 permit in 1995, which was renewed in 2004 and modified in 2005. The initial SWMP created 8 categories of BMPs including: Operation and Maintenance (OM), Structural Controls (STR), Public Education (ED), Public Involvement (PI), Illicit Discharge Controls (ILL), New and Redevelopment Standards (ND), Industrial/Commercial Controls (IND), and Planning/System Preservation and Development (PS). Despite the development of a SWMP however, the city was implementing a few stormwater management practices prior to 1993 including: street sweeping (OM), watershed restoration activities (PS), and designation of environmental buffer zones near streams (PS). Major changes to the City's SWMP over time includes the addition of tracking measures or goals following reporting revisions in 2004 by DEQ, and expansion or removal of the initial 8 BMP categories. 
The current MS4 permit was issued in 2011 and expired on January 30, 2016. The City submitted a permit renewal application in 2015 and were granted an extension of the 2011 permit by DEQ for the duration of the renewal process. The city is currently operating under their 2011 SWMP until they are issued a new NPDES permit. A summary of BMPs that were addressed in the city’s 2011 SWMP to prevent bacterial discharges to Johnson Creek can be found in the table below (Table 15).

\section{NPDES (MS4) Activities}

Table 15. Summary of BMPs implemented by COP in their 2005-2010 NPDES permit cycle and 2011-2016 permit cycle addressing potential sources of bacterial discharge to JC.

\begin{tabular}{|c|c|c|c|c|}
\hline TYPE & $\begin{array}{l}\text { BEST } \\
\text { MANAGEMENT } \\
\text { PRACTICES (BMPs) }\end{array}$ & GOALS & REPORTING ELEMENTS & STATUS \\
\hline \multirow[t]{2}{*}{$\begin{array}{l}\text { Public } \\
\text { Involvement } \\
\text { and Education } \\
\text { (PI and ED) }\end{array}$} & $\begin{array}{l}\text { Clean Rivers Education } \\
\text { Programs }\end{array}$ & $\begin{array}{l}\text {-Prior to } 2011 \text { no goals } \\
\text { were established } \\
\text {-Provide outreach to } \\
\text { approximately 15,500 K- } \\
12 \text { students annually } \\
\text { (City wide) }\end{array}$ & $\begin{array}{l}\text { 1. \# of K-12 students exposed to } \\
\text { outreach via classwork programs. } \\
\text { 2. \# of K-12students involved in } \\
\text { educational field programs. }\end{array}$ & 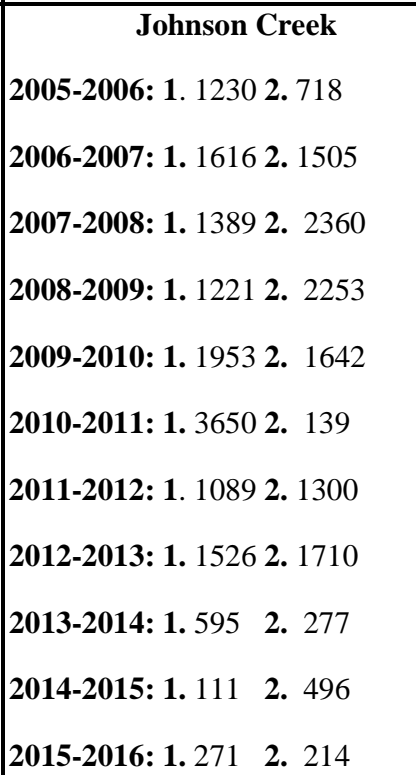 \\
\hline & $\begin{array}{l}\text { Community Stewardship } \\
\text { Grants Program }\end{array}$ & $\begin{array}{l}\text {-Prior to } 2011 \text { no goals } \\
\text { were established } \\
\text {-Award at least } \$ 50,000 \\
\text { in community }\end{array}$ & $\begin{array}{l}\text {-Amount of money annually } \\
\text { allocated to stewardship grants. }\end{array}$ & $\begin{array}{l}\text { Johnson Creek } \\
\text { 2005-2006: } \$ 8000 \text { allocated to } \\
\text { community plantings and youth } \\
\text { education. }\end{array}$ \\
\hline
\end{tabular}




\begin{tabular}{|c|c|c|c|}
\hline & $\begin{array}{l}\text { stewardship grants } \\
\text { annually (City wide). }\end{array}$ & & $\begin{array}{l}\text { 2006-2007: } \$ 10000 \text { allocated to } \\
\text { upland restoration, community } \\
\text { plantings, and youth education. } \\
\text { 2007-2008: } \$ 9750 \text { allocated to } \\
\text { community plantings and youth } \\
\text { education. } \\
\text { 2008-2009: Not Specified } \\
\text { 2009-2010: Not Specified } \\
\text { 2010-2011: } \$ 27,333 \text { allocated to } \\
\text { riparian restoration } \\
\text { 2011-2012: } \$ 12401 \text { allocated to } \\
\text { riparian restoration \& green } \\
\text { infrastructure projects } \\
\text { 2012-2013: } \$ 21900 \text { allocated to } \\
\text { riparian restoration and education } \\
\text { 2013-2014: } \$ 17990 \text { to green } \\
\text { infrastructure } \\
\text { 2014-2015: } \$ 4500 \text { to clean up } \\
\text { bioswales } \\
\text { 2015-2016: } \$ 15,227 \text { for tree } \\
\text { planting in Springwater corridor and } \\
\text { installation of an Ecoroof near } S E \\
\text { 92nd }\end{array}$ \\
\hline $\begin{array}{l}\text { Watershed Education } \\
\text { and Stewardship }\end{array}$ & $\begin{array}{l}\text {-Prior to } 2011 \text { no goals } \\
\text { were established. } \\
\text {-Involve approximately } \\
\text { 10,000 participants in } \\
\text { community events, } \\
\text { workshops, stewardship } \\
\text { projects, and restoration } \\
\text { events annually }\end{array}$ & $\begin{array}{l}\text {-\# of annual participants \& } \\
\text { restoration activities performed }\end{array}$ & $\begin{array}{l}\text { Johnson Creek } \\
\text { 2005-2006: Over } 400 \text { volunteers } \\
\text { participated in tree plantings and } \\
\text { waste pickup around watershed. } \\
\text { 2006-2007: } 340 \text { volunteers } \\
\text { participated in tree plantings and } \\
\text { waste pickup around watershed. } \\
\text { 2007-2008: } 400 \text { volunteers planted } \\
\text { 6,000 native plants and hauled away } \\
1 \text { ton of trash from } 14 \text { sites. } \\
\text { 2008-2009: } 350 \text { volunteers planted } \\
\text { 4,840 native plants and hauled away } \\
\text { 17 bags of trash from } 10 \text { sites. } \\
\text { 2009-2010: } 335 \text { volunteers planted } \\
6,285 \text { native plants and hauled away } \\
19 \text { bags of trash. } \\
\text { 2010-2011: } 356 \text { volunteers planted } \\
\text { native trees/shrubs and participated } \\
\text { in other watershed improvement } \\
\text { activities. }\end{array}$ \\
\hline
\end{tabular}




\begin{tabular}{|c|c|c|c|c|}
\hline & & & & $\begin{array}{l}\text { 2011-2012: 9,585 native trees } \\
\text { planted by } 385 \text { volunteers. } \\
\text { 2012-2013: Involved } 470 \\
\text { volunteers in watershed } \\
\text { improvement activities. } \\
\text { 2013-2014: Involved } 260 \\
\text { volunteers in watershed } \\
\text { improvement activities. } \\
\text { 2014-2015: Involved } 855 \\
\text { volunteers in clean up and } \\
\text { watershed improvement activities } \\
\text { 2015-2016: Involved } 443 \\
\text { volunteers in clean up and } \\
\text { watershed improvement activities }\end{array}$ \\
\hline $\begin{array}{l}\text { Operations and } \\
\text { Maintenance } \\
(\mathrm{OM})\end{array}$ & $\begin{array}{l}\text { Maintenance and } \\
\text { cleaning of system } \\
\text { components }\end{array}$ & $\begin{array}{l}\text {-Prior to 2011, no goals } \\
\text { were set. } \\
\text {-Maintenance actions } \\
\text { over the five-year permit } \\
\text { cycle:2011-2016 } \\
\text { 1. (Culverts) Clean } \\
\text { 31,000 } \\
\text { 2.(Culverts) Repair } \\
\text { 10,000 } \\
\text { 3.(Ditches) Clean } \\
\text { 250,000 } \\
\text { 4. Clean 38,000 inlets } \\
\text { and catch basins. } \\
\text { 6. Clean } 135 \text { major } \\
\text { stormwater management } \\
\text { facilities (SMF) } \\
\text { 7. Repair } 1,500 \text { inlets } \\
\text { and inled leads. }\end{array}$ & $\begin{array}{l}\text {-linear feet culverts cleaned } \\
\text {-linear feet culverts repaired. } \\
\text {-linear feet of ditches cleaned. } \\
\text {-\# of catch basins and inlets } \\
\text { cleaned. } \\
\text {-\# of inlets repaired. } \\
\text {-\# of pollution reduction facilities } \\
\text {-\# of stormwater management } \\
\text { facilities (SMF) cleaned. }\end{array}$ & 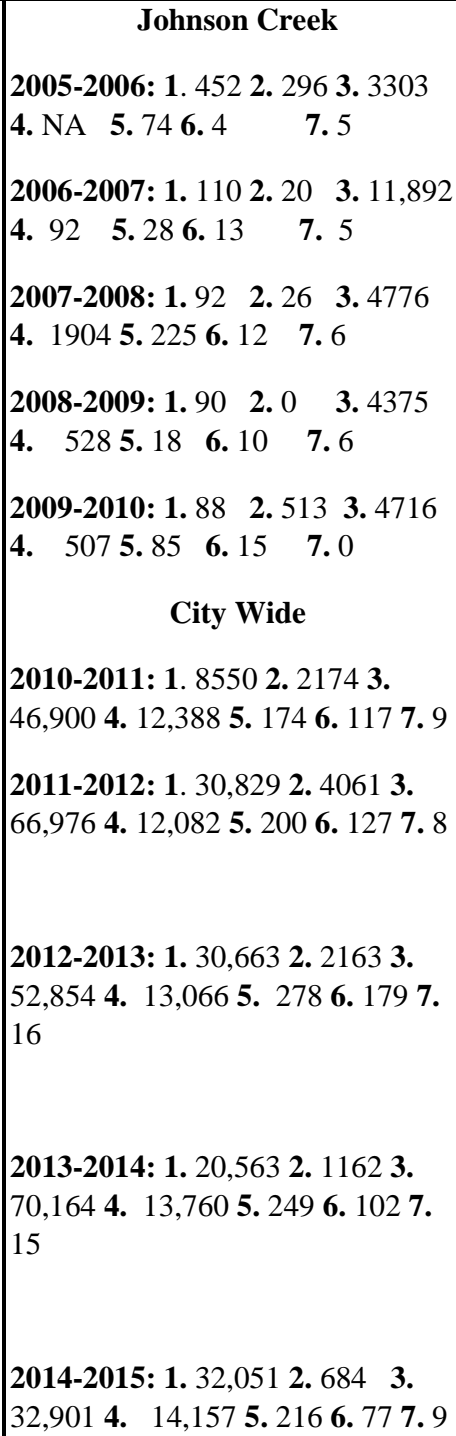 \\
\hline
\end{tabular}




\begin{tabular}{|c|c|c|c|c|}
\hline & & & & $\begin{array}{l}\text { 2015-2016: 1. 15,363 2. } 265 \text { 3. } \\
32,054 \text { 4. 11,372 5. } 299 \text { 6. } 103 \text { 7. } 4\end{array}$ \\
\hline & $\begin{array}{l}\text { Limit pollutant } \\
\text { discharges to MS4 } \\
\text { during O\&M procedures }\end{array}$ & $\begin{array}{l}\text {-No goals stated prior to } \\
2011 . \\
\\
\text { - In } 2011 \text { a city wide } \\
\text { goal of } 6 \text { arterial sweeps } \\
\text { per year was established. }\end{array}$ & $\begin{array}{l}\text {-\# of sweeps per year } \\
\text {-\# miles of ms4 area swept } \\
\text {-\# material collect (cubic yards) }\end{array}$ & $\begin{array}{l}\text { Johnson Creek } \\
\text { 2005-2006: } \text { NA, } 45 \text { miles, } 602 \text { cy } \\
\text { 2006-2007: NA, } 25.59 \text { miles,342 cy } \\
\text { 2007-2008: NA, } 25.53 \text { miles,341 cy } \\
\text { 2008-2009: NA, } 30 \text { miles, 401cy } \\
\text { 2009-2010: } \text { NA, } 404 \text { miles, } 202 \text { cy } \\
\text { City Wide } \\
\text { 2010-2011: } 6 \text { sweeps,NA,NA } \\
\text { 2011-2012: } 6 \text { sweeps,NA,NA } \\
\text { 2012-2013: } 6 \text { sweeps,NA,NA } \\
\text { 2013-2014: } 6 \text { sweeps,NA,NA } \\
\text { 2014-2015: } 6 \text { sweeps,NA,NA } \\
\text { 2015-2016: } 6 \text { sweeps,NA,NA }\end{array}$ \\
\hline \begin{tabular}{|l} 
Illicit \\
Discharge \\
Controls \\
(ILL)
\end{tabular} & $\begin{array}{l}\text { Illicit Discharge } \\
\text { Elimination Program } \\
\text { (IDEP) }\end{array}$ & $\begin{array}{l}\text { Conduct dry weather } \\
\text { sampling at all major } \\
\text { City-owned outfalls at } \\
\text { least once annually, with } \\
\text { a minimum of three } \\
\text { inspections for priority } \\
\text { outfalls. }\end{array}$ & $\begin{array}{l}\text {-Monitoring sites (outfalls) } \\
\text { inspected } \\
\text {-Number further investigated } \\
\text {-Illicit Discharge (ID) identified } \\
\text {-Follow up action }\end{array}$ & $\begin{array}{l}\text { Johnson Creek } \\
\text { 2005-2006: } 0 \text { sites, NA, NA, NA, } \\
\text { NA } \\
\text { 2006-2007: } 1 \text { site for July-Oct, } \\
\text { None, None, No follow-up needed. } \\
\text { 2007-2008: } 19 \text { sites in July \& } 1 \text { site } \\
\text { for August/Sept, None, None, No } \\
\text { follow-up needed. } \\
\text { 2008-2009: } 9 \text { sites in July and } 1 \text { site } \\
\text { in August/Sept, None, None, No } \\
\text { follow-up needed } \\
\text { 2009-2010: } 9 \text { sites in June and } 1 \\
\text { site in July and Oct, None, None, } \\
\text { No follow-up needed. } \\
\text { 2010-2011: NA, NA, } 0 \text { ID, No } \\
\text { follow up needed } \\
\text { 2011-2012: } 2 \text { sites August \& } 4 \text { in } \\
\text { Sept, None, None, No follow up } \\
\text { needed } \\
\text { 2012-2013: } 5 \text { sites in June/July, } 4 \text {, } \\
\text { None, No follow-up needed. }\end{array}$ \\
\hline
\end{tabular}




\begin{tabular}{|c|c|c|c|c|}
\hline & & & & $\begin{array}{l}\text { City Wide } \\
\text { 2013-2014: } 112 \text { sites, None, None, } \\
\text { No follow-up needed } \\
\text { 2014-2015: } 110 \text { sites, None, None, } \\
\text { No follow-up needed } \\
\text { 2015-2016: } 109 \text { sites, 47, } 1 \text { ID } \\
\text { found due to damaged sanitary line } \\
\text { (discharging to MS4) which was } \\
\text { repaired }\end{array}$ \\
\hline & $\begin{array}{l}\text { Implement Solid Waste } \\
\text { Program to Prevent } \\
\text { Illegal Dumping }\end{array}$ & -No goals set & NA & \\
\hline $\begin{array}{l}\text { Natural } \\
\text { Systems }\end{array}$ & $\begin{array}{l}\text { Assess and implement } \\
\text { watershed projects that } \\
\text { enhance, preserve, and } \\
\text { protect natural areas and } \\
\text { vegetation. }\end{array}$ & $\begin{array}{l}\text {-No goals set prior to } \\
2011 \text { permit cycle. } \\
\text {-Plant 20,000 trees and } \\
\text { initiate revegetation } \\
\text { work on } 70 \text { acres by end } \\
\text { of permit cycle (2011- } \\
2016)\end{array}$ & $\begin{array}{l}\text { Watershed Revegetation Program: } \\
\text { \# of trees/plants planted along } \\
\text { streambanks and \# of acres. }\end{array}$ & $\begin{array}{l}\text { Johnson Creek } \\
\text { 2005-2006: } 28,277 \text { plants along } \\
\text { 12.77 acres } \\
\text { 2006-2007: } 9698 \text { plants along } 12.5 \\
\text { acres } \\
\text { 2007-2008: } 43,954 \text { plants along } \\
34.4 \text { acres } \\
\text { 2008-2009: } 6922 \text { plants along } 27 \\
\text { acres } \\
\text { 2009-2010: } 18,477 \text { plants along } 73 \\
\text { acres } \\
\text { 2010-2011: } 8770 \text { plants along } 11 \\
\text { acres } \\
\text { 2011-2012: } 72,413 \text { plants along } \\
\text { 133.75 acres } \\
\text { 2012-2013: } 50,227 \text { plants along } \\
126.7 \text { acres } \\
\text { 2013-2014: } 20,556 \text { plants along } 44 \\
\text { acres } \\
\text { 2014-2015: } 24,059 \text { plants along } \\
\text { 22.9 acres } \\
\text { 2015-2016: } 17,463 \text { plants along } \\
\text { 19.5 acres }\end{array}$ \\
\hline $\begin{array}{l}\text { Structural } \\
\text { Control } \\
\text { (STR) }\end{array}$ & $\begin{array}{l}\text { Continue onsite retrofits } \\
\text { and improvements } \\
\text { through the Technical } \\
\text { Assistance, Incentives, } \\
\text { and Grants Programs. }\end{array}$ & $\begin{array}{l}\text {-No goals set for city } \\
\text { wide or Johnson Creek }\end{array}$ & $\begin{array}{l}\text {-Location (watershed), and type of } \\
\text { projects implemented }\end{array}$ & $\begin{array}{l}\text { Johnson Creek } \\
\text { 2005-2006: Began predesign of } \\
\text { Lents interceptor crossing project, } \\
\text { and completed construction of } \\
\text { passive stormwater facility (17th } \\
\text { Ave) that will treat } 9 \text { acres of } \\
\text { residential land. }\end{array}$ \\
\hline
\end{tabular}




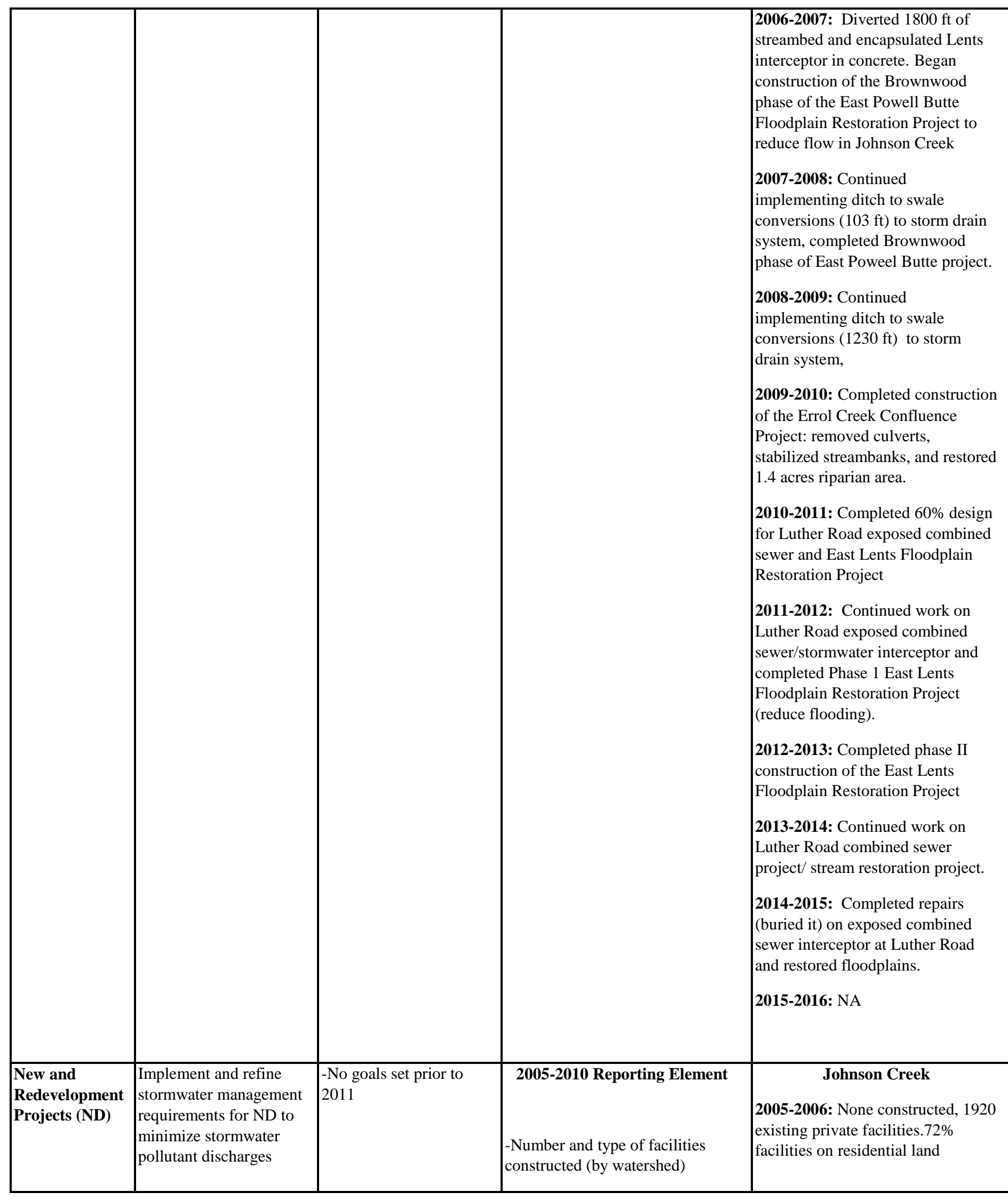




\begin{tabular}{|c|c|c|c|c|}
\hline & & $\begin{array}{l}\text {-Inspect 1,500 private } \\
\text { stormwater facilities or } \\
450 \text { properties annually. }\end{array}$ & $\begin{array}{l}\text { - } \\
\text { 2010-2016 Reporting Element } \\
\text {-Number of private properties } \\
\text { inspected. } \\
\text {-Number of stormwater facilities } \\
\text { inspected } \\
\text {-Number of new facilities installed } \\
\text {-Impervious area managed by new }\end{array}$ & 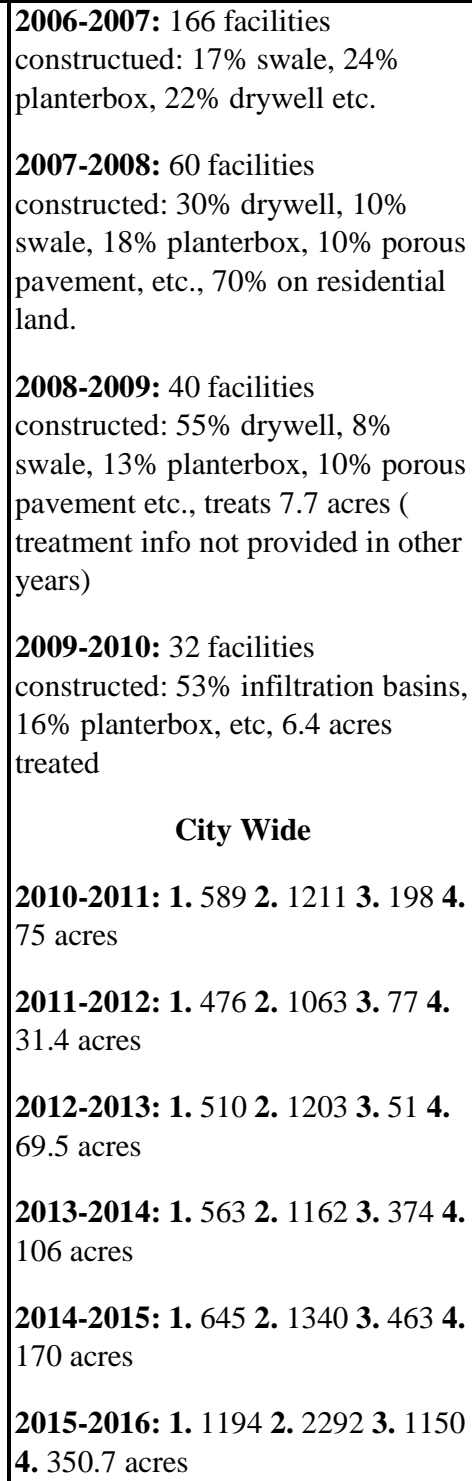 \\
\hline
\end{tabular}




\section{TMDL Implementation Plan Background}

Following the adoption of the Lower Willamette Basin TMDL in September of 2006, the City of Portland and other agencies listed under the TMDL as DMAs were required to develop and submit TMDL implementation plans to DEQ within 12-18 months. The plans were to include proposed strategies to reduce pollutant loading, a schedule of implementation activities, performance monitoring strategies, and analyses required by other water quality management plans (including SWMPs). Portland submitted its TMDL implementation plan to DEQ in 2008 and began implementation of the program in 2009 following approval by DEQ. The plan was subsequently revised in 2013 following the 5 year TMDL review period which requires DMAs to highlight the successes and limitations of TMDL management strategies and make updates to the TMDL implementation plan. The TMDL implementation plan was approved by DEQ in February of 2014 and the city began implementing their updated BMPs. With the exception of the Lents Interceptor Repair Project, Portland’s 2008 and 2014 TMDL implementation plans do not directly address nonpoint sources of bacteria. This may be attributed to the fact that major nonpoint bacterial sources, such as septic systems, are not common within the city and fall under Multnomah County jurisdiction (Multnomah County, 2014) or it may be related to the fact that nonMS4 regions within the city are not thought to be hydrologically connected to Johnson Creek (BES, 2005). TMDL activities reported by the city primarily include restoration of riparian areas and stream channels to promote infiltration to riparian areas and to attempt to restore natural flow conditions (Table 16). 


\section{TMDL Activities}

Table 16. Summary of major TMDL projects implemented by City of Portland within Johnson Creek.

\begin{tabular}{|c|c|c|c|}
\hline PROJECT & DESCRIPTION & STATUS & MITIGATION MEASURE \\
\hline $\begin{array}{l}\text { Lents Interceptor } \\
\text { Repair Project }\end{array}$ & $\begin{array}{l}\text { Project addresses a } \\
\text { combined sewer } \\
\text { interceptor pipe that } \\
\text { crosses JC at SE } 39^{\text {th }} \\
\text { Ave. When the pipe } \\
\text { was initially } \\
\text { constructed it was } \\
\text { buried beneath the } \\
\text { water table with holes } \\
\text { in it to prevent it from } \\
\text { surfacing. During dry } \\
\text { periods however, there } \\
\text { is potential for } \\
\text { wastewater discharge if } \\
\text { the water table drops } \\
\text { below the pipe. (BES, } \\
\text { 1994) }\end{array}$ & $\begin{array}{l}\text { Began in } 2005 \text { and } \\
\text { completed in the } \\
\text { Summer of } 2006\end{array}$ & $\begin{array}{l}\text { Diverted 1,700 feet of the creek around interceptor, } \\
\text { encapsulated interceptor with concrete, and covered the } \\
\text { reinforced pipe with rock to build the base of Johnson } \\
\text { Creek up over the pipe. The project mimics natural } \\
\text { stream dynamics, and cost less than moving the pipe. }\end{array}$ \\
\hline $\begin{array}{l}\text { Luther Road } \\
\text { Restoration Project }\end{array}$ & $\begin{array}{l}\text { Project to restore } 2000 \\
\text { feet of floodplains near } \\
\text { Luther Road in JC. The } \\
\text { Lents Interceptor pipe } \\
\text { crosses the creek at the } \\
\text { project site and could } \\
\text { be damaged from } \\
\text { restoration activates. } \\
\text { The project seeks to } \\
\text { reinforce the } \\
\text { interceptor before and } \\
\text { restoration activities } \\
\text { occur. }\end{array}$ & $\begin{array}{l}\text { Construction began } \\
\text { in spring of } 2013 \text { and } \\
\text { project was } \\
\text { completed in } 2014\end{array}$ & $\begin{array}{l}\text { Buried the Lents Interceptor pipe, and restored and } \\
\text { relocated } 2000 \text { feet of floodplains in Johnson Creek near } \\
\text { Luther Road. }\end{array}$ \\
\hline $\begin{array}{l}\text { East Lents Floodplain } \\
\text { Restoration Project }\end{array}$ & $\begin{array}{l}\text { Project intended to } \\
\text { reduce flooding in the } \\
\text { creek by restoring } \\
\text { floodplains to allow for } \\
\text { greater infiltration } \\
\text { which should in turn } \\
\text { improve base flow } \\
\text { conditions downstream. } \\
\text { The project is located } \\
\text { south of SE Foster } \\
\text { Road. }\end{array}$ & $\begin{array}{l}\text { Began project design } \\
\text { in } 2009 \text { and } \\
\text { completed } \\
\text { construction in } 2011 .\end{array}$ & Restored 70 acres of floodplains to natural conditions. \\
\hline
\end{tabular}




\section{City of Gresham}

The City of Gresham was listed as a DMA by DEQ in the 2006 Bacteria TMDL for Johnson Creek. The city is located within Multnomah County, east of Portland, and receives inputs from Johnson Creek near Palmblad Road in the upper portion of watershed (Figure 4). Of the 54 square miles that encompasses the Johnson Creek Watershed, 8.6 square miles are within the city's MS4 permit area. The city is responsible for managing point and non-point bacterial discharges to the stream by adopting and modifying as needed a SWMP and TMDL Implementation Plan respectively.

\section{NPDES (MS4) Background}

A SWMP for the City of Gresham was developed in 1993 and an NPDES (MS4) permit was issued to the city by DEQ in 1995, which was valid for a 5 year duration. Gresham's 1993 SWMP developed 7 general BMP categories with more specific activities falling under each category. The categories included Public Involvement and Education, Operations and Maintenance, Illicit Discharge Controls, New Development Standards, Structural Controls, Natural Systems, and Program Management. Issuance of the second MS4 permit was postponed by DEQ until 2005 and updated its SWMP with DEQ in 2001 and again in 2006, which also included the creation of a TMDL plan and a few additional reporting measures for bacteria. DEQ renewed the permit again in 2010-2015 and approved a new SWMP in 2011, which is still being implemented as the City's permit is currently under administrative extension and awaiting renewal. The annual progress of BMPs implemented by the city to address bacterial discharges to Johnson Creek can be found in the table below for the years 2006-2016 (Table 17). 
NPDES (MS4) Activities

Table 17. Summary of annual BMP implementation progress to address bacterial discharge to JC by COG for the years 20062016. Data was collected from MS4 annual reports from Gresham’s 2005-2010 permit cycle, 2010-2015 permit cycle, and includes implementation activities for 2015-2016. *Note: these years cover two different SWMPs and as such, do not have identical reporting requirements for all BMPs across years.

\begin{tabular}{|c|c|c|c|}
\hline $\begin{array}{l}\text { BEST MANAGEMENT } \\
\text { PRACTICES (BMPs) }\end{array}$ & GOALS & $\begin{array}{l}\text { TRACKING } \\
\text { MEASURE }\end{array}$ & STATUS \\
\hline Pipe Cleaning & $\begin{array}{l}\text { Clean and Inspect 15-20 } \\
\text { miles of pipe per year. }\end{array}$ & $\begin{array}{l}\text {-Miles cleaned } \\
(2006-2016) \\
\text {-Volume of debris } \\
\text { removed (2006-2016) } \\
\text { (cubic yard) }\end{array}$ & $\begin{array}{l}\text { City Wide } \\
\text { 2006-2007: } 19.6 \mathrm{mi}, 43.5 \text { cy } \\
\text { 2007-2008: } 17.8 \mathrm{mi}, 25 \text { cy } \\
\text { 2008-2009: } 15.6 \mathrm{mi}, 27 \text { cy } \\
\text { 2009-2010: } 19 \text { mi, } 29 \text { cy } \\
\text { 2010-2011: } 15.3 \text { mi, } 15 \text { cy } \\
\text { 2011-2012: } 15 \text { mi, } 12.9 \text { cy } \\
\text { 2012-2013: } 17.4 \text { mi, } 4.4 \text { cy } \\
\text { 2013-2014: } 17 \text { mi, } 4.4 \text { cy } \\
\text { 2014-2015: } 16 \text { mi, } 3.2 \text { cy } \\
\text { 2015-2016: } 15.5 \mathrm{mi}, 3.8 \text { cy }\end{array}$ \\
\hline Catch Basin Cleaning & $\begin{array}{l}\text { Clean or inspect all } \\
\text { publicly owned catch } \\
\text { basins that drain to } \\
\text { surface water once per } \\
\text { year. }\end{array}$ & $\begin{array}{l}\text {-Total catch basins } \\
\text { cleaned (2006-2016) } \\
\text {-Volume of debris } \\
\text { removed (2006-2016) } \\
\text { (cubic yard) } \\
\text {-Percent cleaned }\end{array}$ & $\begin{array}{l}\text { City Wide } \\
\text { 2006-2007:6142cb, (NA), } 132 \text { cy } \\
\text { 2007-2008:6021cb, (NA), } 130 \text { cy } \\
\text { 2008-2009: 6190cb (100\%), } 109 \text { cy } \\
\text { 2009-2010: 6260cb (100\%),121.4 cy } \\
\text { 2010-2011: 6180cb (100\%), } 75.8 \text { cy } \\
\text { 2011-2012: 6558cb (100\%), } 109 \text { cy } \\
\text { 2012-2013: 6455cb (98\%), } 155 \text { cy } \\
\text { 2013-2014: 6375cb (97\%), } 144 \text { cy } \\
\text { 2014-2015: 6259cb (100\%), } 126 \text { cy } \\
\text { 2015-2016: 6132cb ( } 98 \%), 139 c y\end{array}$ \\
\hline $\begin{array}{l}\text { Maintain Public Water } \\
\text { Quality Facilities }\end{array}$ & $\begin{array}{l}\text { Maintain an average } 20- \\
25 \text { facilities per year over } \\
\text { the permit term. (Annual } \\
\text { totals may vary }\end{array}$ & $\begin{array}{l}\text { 1. Number \& type of } \\
\text { facilities inspected. } \\
\text { 2. Volume of } \\
\text { debris/waste removed } \\
\text { from facility. }\end{array}$ & $\begin{array}{l}\text { City Wide } \\
\text { 2006-2007: 1. } 14 \text { PD, } 85 \text { facilities: P, S \& RG 2. } 63 \\
\text { filters changed, } 85 \text { cy debris removed. } \\
\\
\text { 2007-2008: 1. } 49 \text { PD, } 75 \text { facilities-type unknown } 2 . \\
\text { 273 filters for PD replaced \& } 20 \text { cy waste removed. }\end{array}$ \\
\hline
\end{tabular}




\begin{tabular}{|c|c|c|c|}
\hline & & $\begin{array}{l}\text { (cubic yard) } \\
\text { RF=Regional Facility } \\
\text { S=Swale } \\
\text { RG=Raingarden } \\
\text { P=Ponds } \\
\text { PD=Proprietary Device }\end{array}$ & 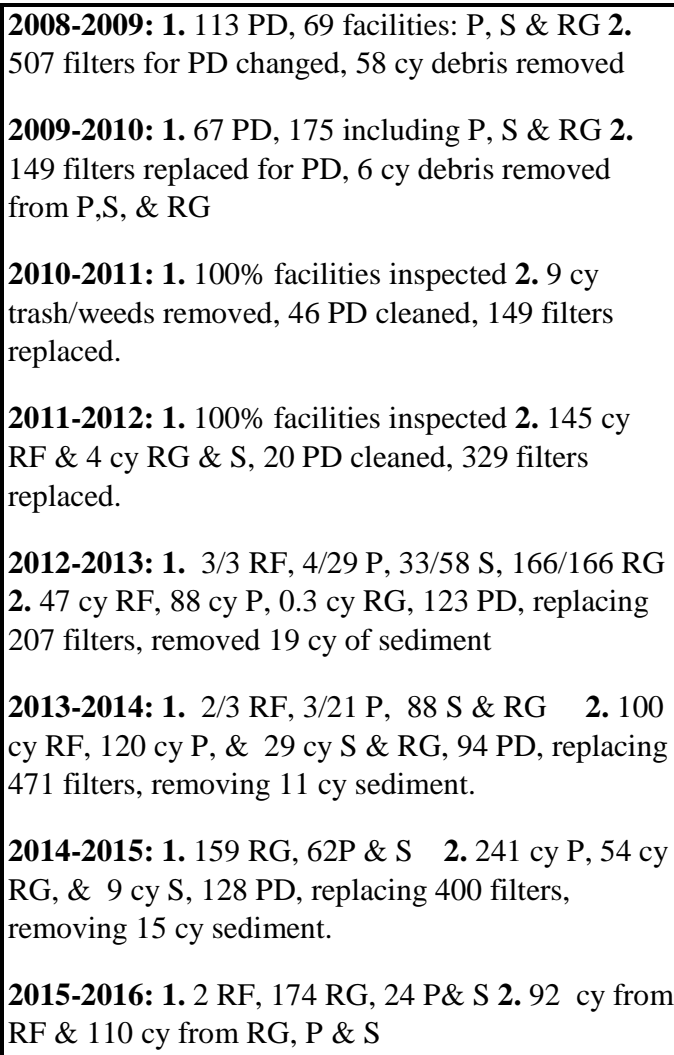 \\
\hline $\begin{array}{l}\text { Inspect and Clean } \\
\text { Sedimentation and Flow } \\
\text { Control Manholes. (SMH } \\
\text { \& FCM) }\end{array}$ & $\begin{array}{l}\text { Inspect } 75 \% \text { of manhole } \\
\text { structures annually and } \\
\text { clean as needed (2010). }\end{array}$ & $\begin{array}{l}\text {-Number of structures } \\
\text { Inspected and } \\
\text { cleaned/repaired. } \\
\text { (I\&C/I\&R) } \\
\text { - Volume of debris } \\
\text { removed (2006-2016) } \\
\text {-Percent cleaned }\end{array}$ & $\begin{array}{l}\text { City Wide } \\
\text { 2006-2007: } 28 \text { I\&C, } 6.6 \text { cy } \\
\text { 2007-2008: } 109 \text { I\&C, } 28 \text { cy } \\
\text { 2008-2009: } 140 \text { I\&C, } 57 \text { cy, } \\
\text { 2009-2010: } 142 \text { I\&C, } 54.5 \text { cy } \\
\text { 2010-2011: } 167 \text { Inspected (55\%),149 cleaned, } 57.3 \\
\text { cy } \\
\text { 2011-2012: } 100 \% \text { inspected, } 11 \text { structures repaired, } \\
\text { 47 SMH \% } 1 \text { FCM cleaned. } \\
\text { 2012-2013: } 8 / 242 \text { SMH cleaned and } 100 \% \\
\text { inspected, } 180 / 193 \text { FCM cleaned and } 98 \% \\
\text { inspected, } 71 \text { cy } \\
\text { 2013-2014: Inspected } 100 \% \text { structures, } 45 \text { cy } \\
\text { 2014-2015: Inspected } 100 \% \text { structures, } 63 \text { cy } \\
\text { 2015-2016: Inspected } 100 \% \text { structures, } 48 \text { cy }\end{array}$ \\
\hline $\begin{array}{l}\text { Promote Low Impact } \\
\text { Development } \\
\text { (LID)Practices }\end{array}$ & $\begin{array}{l}\text { Track location, drainage } \\
\text { area and type of LID that } \\
\text { is built. }\end{array}$ & $\begin{array}{l}\text { 1. acres treated from } \\
\text { installation of green } \\
\text { infrastructure }\end{array}$ & $\begin{array}{l}\text { City Wide } \\
\text { 2006-2007: Not calculated (NC), NC } \\
\text { 2007-2008: NC, NC } \\
\text { 2008-2009: NC, NC }\end{array}$ \\
\hline
\end{tabular}




\begin{tabular}{|c|c|c|c|}
\hline & & $\begin{array}{l}\text { 2.acres disturbed from } \\
\text { construction in MS4 } \\
\text { See Table \# for projects } \\
\text { with water quality } \\
\text { benefits }\end{array}$ & $\begin{array}{l}\text { 2009-2010: NC, NC } \\
\text { 2010-2011: } 19.71 \text { acres, } 8.9 \text { acres } \\
\text { 2011-2012: } 59.16 \text { acres, } 6.4 \text { acres } \\
\text { 2012-2013: } 34.8 \text { acres, } 7.66 \text { acres } \\
\text { 2013-2014: } 6.8 \text { acres, } 2.72 \text { acres } \\
\text { 2014-2015: } 65.8 \text { acres, } 45.7 \text { acres } \\
\text { 2015-2016: } 24.1 \text { acres, } 29.8 \text { acres }\end{array}$ \\
\hline $\begin{array}{l}\text { Enhanced Riparian } \\
\text { Areas }\end{array}$ & $\begin{array}{l}\text { Collaborate and seek } \\
\text { grant funding to } \\
\text { implement restoration } \\
\text { projects that will reduce } \\
\text { pollutant discharge. }\end{array}$ & $\begin{array}{l}\text { - number trees/ plants, } \\
\text { Site, Acreage }\end{array}$ & $\begin{array}{l}\text { 2006-2007: } 665 \text { Hogan, } 0.1 \text { ac, } 1006 \text { Kelley, } 0.19 \text { ac } \\
\text { 2007-2008: } 4179 \text { Kelley, } 1.25 \text { ac } \\
\text { 2008-2009: } 2000 \text { Hogan, } 6 \text { ac, } 3000 \text { Kelley, } 3 \text { ac } \\
\text { 2009-2010: } 1155 \text { Hogan, } 5 \text { ac, } 3388 \text { Kelley, } 6 \text { ac } \\
\text { 2010-2011: } 483 \text { Hogan, } 5 \text { ac, } 812 \text { Kelley, } 4.4 \text { ac } \\
\text { 2011-2012: } 483 \text { Hogan, } 5 \text { ac, } 812 \text { Kelley, } 4.4 \text { ac } \\
\text { 2012-2013: } 4200 \text { Kelley, } 4.4 \text { ac } \\
\text { 2013-2014: } 620 \text { Hogan, } 20 \text { ac, } 4200 \text { Kelley, } 4 \text { ac } \\
\text { 2014-2015: } 2400 \text { JC reach 1, } 3.5 \text { ac, } 1630 \text { Hogan, } 3 \\
\text { ac } \\
\text { 2015-2016: } 2105 \text {, Jenne, } 5 \text { ac, } 1305 \text {, Kelly, } 4.5 \text { ac }\end{array}$ \\
\hline Street Sweeping & $\begin{array}{l}\text { Provide 8-10 sweeps per } \\
\text { years }\end{array}$ & $\begin{array}{l}\text {-Sweeps per year } \\
\text {-Miles swept } \\
\text {-Volume debris (cubic } \\
\text { yard) }\end{array}$ & $\begin{array}{l}\text { 2006-2007: } 10 \text { sweeps, } 6007 \text { mi, } 3225 \text { cy } \\
\text { 2007-2008: } 10 \text { sweeps, } 7208 \text { mi, } 1388 \text { cy } \\
\text { 2008-2009: } 10 \text { sweeps, } 5100 \text { mi, } 2663 \text { cy } \\
\text { 2009-2010: } 10 \text { sweeps, } 5200 \text { mi, } 2663 \text { cy } \\
\text { 2010-2011: } 10 \text { sweeps, } 4973 \text { mi, } 2354 \text { cy } \\
\text { 2011-2012: } 10 \text { sweeps, } 4173 \text { mi, } 2019 \text { cy } \\
\text { 2012-2013: } 10 \text { sweeps, } 4599 \text { mi, } 2516 \text { cy } \\
\text { 2013-2014: } 10 \text { sweeps, } 4844 \text { mi, } 2443 \text { cy } \\
\text { 2014-2015: } 10 \text { sweeps, } 5800 \text { mi, } 2002 \text { cy } \\
\text { 2015-2016: } 10 \text { sweeps, } 5800 \text { mi, } 1300 \text { cy }\end{array}$ \\
\hline $\begin{array}{l}\text { Inspect newly installed } \\
\text { pipes for illicit } \\
\text { connections. }\end{array}$ & $\begin{array}{l}\text { Inspect } 80 \% \text { of pipes } \\
\text { installed in the city. }\end{array}$ & -percent inspected & $\begin{array}{l}\text { 2006:-2016: } 100 \% \text { of newly installed pipes } \\
\text { inspected }\end{array}$ \\
\hline $\begin{array}{l}\text { Field Screening and } \\
\text { Investigation at high } \\
\text { priority outfalls. }\end{array}$ & $\begin{array}{l}\text { Conduct dry weather field } \\
\text { investigations and } \\
\text { document an enforcement } \\
\text { plan for illicit discharges } \\
\text { (ID). }\end{array}$ & $\begin{array}{l}\text {-Monitoring sites } \\
\text { inspected }\end{array}$ & $\begin{array}{l}\text { City Wide } \\
\text { 2006-2007: } 35 \text { sites, } 5 \text { w/flow, no follow up needed } \\
\text { 2007-2008: } 35 \text { sites, } 6 \text { w/flow, elevated bacteria at } 1 \\
\text { site in JC but no source identified. }\end{array}$ \\
\hline
\end{tabular}




\begin{tabular}{|c|c|c|c|c|}
\hline & & $\begin{array}{l}\text {-Follow up action if } \\
\text { screening exceeds action } \\
\text { level. }\end{array}$ & $\begin{array}{l}\text { - Number } \\
\text { investigated/identified } \\
\text {-Follow up action }\end{array}$ & $\begin{array}{l}\text { 2008-2009: } 32 \text { sites, } 20 \text { w/ flow, no follow up } \\
\text { needed } \\
\text { 2009-2010: } 32 \text { sites, } 24 \text { w/ flow, no follow up } \\
\text { needed } \\
\text { 2010-2011: } 33 \text { sites, } 25 \text { w/ flow, no follow up } \\
\text { needed } \\
\text { 2011-2012: } 36 \text { sites, } 26 \text { w/ flow, } 2 \text { investigated- no } \\
\text { ID } \\
\text { 2012-2013: } 31 \text { sites, } 23 \text { w/ flow, no follow up } \\
\text { needed } \\
\text { 2013-2014: } 36 \text { sites, } 26 \text { w/ flow, no follow up } \\
\text { needed } \\
\text { 2014-2015: } 32 \text { sites, } 24 \text { w/ flow, } 2 \text { sites exceeded } \\
\text { action level. One site tracked to a plugged } \\
\text { abandoned line, other site to a meat processing } \\
\text { plant- notice of violation was administered requiring } \\
\text { connection to public system. } \\
\text { 2015-2016: } 30 \text { sites, } 20 \text { w/flow, corrected cross } \\
\text { connection with wastewater found on Wilkes Rd. } \\
\text { near } 181^{\text {st }} \text { Ave }\end{array}$ \\
\hline
\end{tabular}


Table 18. Summary of restoration projects implemented within Johnson Creek or Tributaries by City of Gresham

\begin{tabular}{|c|c|c|}
\hline PROJECT & STATUS & MITIGATION MEASURE \\
\hline $\begin{array}{l}\text { Victoria Cottages, Stark and SE 204th } \\
\text { (Kelly Creek) }\end{array}$ & Completed 2008 (PY 14) & $\begin{array}{l}\text { Pervious asphalt on roadways, } \\
\text { pervious concrete for the driveways, } \\
\text { patios and sidewalks. All runoff is } \\
\text { managed through shallow surface } \\
\text { infiltration devices. }\end{array}$ \\
\hline Hogan Rd. Improvements & Completed 2010 (PY 16) & $\begin{array}{l}\text { Constructed over } 12,000 \text { sq ft. of } \\
\text { ROW rain gardens. Both inverted } \\
\text { medians and sidewalk ROW gardens. } \\
\text { Approx. } 42 \text { rain gardens total. } 100 \% \\
\text { of the } 2.4 \text { acre disturbed site has } \\
\text { stormwater treatment. }\end{array}$ \\
\hline Gresham Fairview Trail & $\begin{array}{l}\text { Phase II and III completed to connect } \\
\text { Springwater trail and complete the } 40 \\
\text { mile loop. Pedestrian and bicycle path. } \\
\text { (2010, PY 16) }\end{array}$ & $\begin{array}{l}1.97 \text { miles of porous asphalt. Approx. } \\
2.4 \text { acres total area treated. }\end{array}$ \\
\hline $\begin{array}{l}\text { Butler Creek (JCWS)Corridor Pond } \\
\text { Retrofit Feasibility Study }\end{array}$ & $\begin{array}{l}\text { Feasibility Study, concept development } \\
\text { and site investigations. Completed } \\
\text { 2011(PY 17) }\end{array}$ & $\begin{array}{l}\text { Collecting water quality and flow data } \\
\text { to inform concept design for possibly } \\
\text { retrofitting inline detention pond into } \\
\text { a more natural stream/wetland } \\
\text { complex to improve water quality. }\end{array}$ \\
\hline Club Paesano Bank Stabilization (JCWS) & Completion status Unknown & $\begin{array}{l}250 \text { feet of failure-prone bank (north } \\
\text { bank of Johnson Creek) groomed, } \\
\text { with top of bank re-contoured to } \\
\text { reduce significant slumping. } \\
\text { Bioengineering materials installed, } \\
\text { revegetation started. Partnership with } \\
\text { private property }\end{array}$ \\
\hline $\begin{array}{l}\text { Watershed Enhancement } \\
\text { Planning(JCWS) }\end{array}$ & $\begin{array}{l}\text { Concept development and agency } \\
\text { negotiations. Completed } 2011 \text { (PY 17) }\end{array}$ & $\begin{array}{l}\text { Developing urban wetland and stream } \\
\text { mitigation bank concept to promote } \\
\text { mitigation of future resource impacts } \\
\text { within the same 5th or 6th field HUC. } \\
\text { Prevents loss of habitat, water quality, } \\
\text { hydrologic support, and flood control } \\
\text { functions provided by intact water } \\
\text { resources. }\end{array}$ \\
\hline $\begin{array}{l}\text { Johnson Creek Land Acquisition and } \\
\text { Stabilization }\end{array}$ & Completed 2014 (PY 19) & $\begin{array}{l}\text { Demolished structures and septic on } \\
\text { new } 2.87 \text { acre Johnson Creek main } \\
\text { stem holding (purchased prior } \\
\text { reporting year) }\end{array}$ \\
\hline $\begin{array}{l}\text { Homeless Camping Impacts In Riparian } \\
\text { Area }\end{array}$ & Began 2016 (PY 21), Ongoing & $\begin{array}{l}\text { City resources were spent conducting } \\
\text { camp site cleanups and removal of } \\
\text { human waste. }\end{array}$ \\
\hline
\end{tabular}




\section{TMDL Implementation Plan Background}

The TMDL Implementation Plan for the City of Gresham was submitted to and approved by DEQ in April of 2007. The plan was amended in 2014 following the 5 year TMDL implementation review. The second volume of the implementation plan serves as the Bacteria Management Plan for the city, and is entirely dedicated to addressing bacterial discharges from private on-site treatment systems (i.e. septic systems). Although the city does not regulate on-site systems, which is the responsibility of DEQ and Multnomah County, it has adopted strategies to assist DEQ and the County. The primary strategy of the city to address on-site system discharges is to continually replace septic systems as they fail and require connection to the public system. The city is able to identify on-site system locations based on information regarding addresses that pay stormwater fees rather than wastewater fees. City code currently requires onsite systems to hook up to the sanitary sewer line if within 300 feet of a city system for new and redeveloped areas. Existing onsite systems however, are permitted until failure or property ownership changes. Failed systems are required to hook up to the city sanitary system if available, otherwise a new onsite system is installed. The city expects that by 2033, few on-site systems will remain within the city due to a combination of new development, redevelopment, and system failures (City of Gresham, 2014). In addition to its strategies to address on-site systems, the city has considered the use of DNA Bacterial source tracking as a way to better focus management efforts. 


\section{TMDL Activities}

The City of Gresham has implemented BMPs to address bacterial discharges from private onsite septic systems. The city utilizes five different categories of actions to target and prevent bacterial discharges from failing septic systems. The five categories of BMPs or activities include completing the Mid-County Sewerage Project by connecting the three remaining septic systems in Multnomah County to the public system, connecting new and redeveloped properties to public system, requiring failed systems to connect to the public system, surveying current onsite private septic systems, and responding to reports of private septic system spills. The status summary of activities implemented over the first TMDL five year cycle (2009-2013) as well as the first two years of the current TMDL cycle (2014-2016) is shown below (Table 19).

Table 19. Summary of BMPs outlined in COG 2008 TMDL Implementation Plan, 2014 plan reduces BMPs to NPB-2,3,\&5.

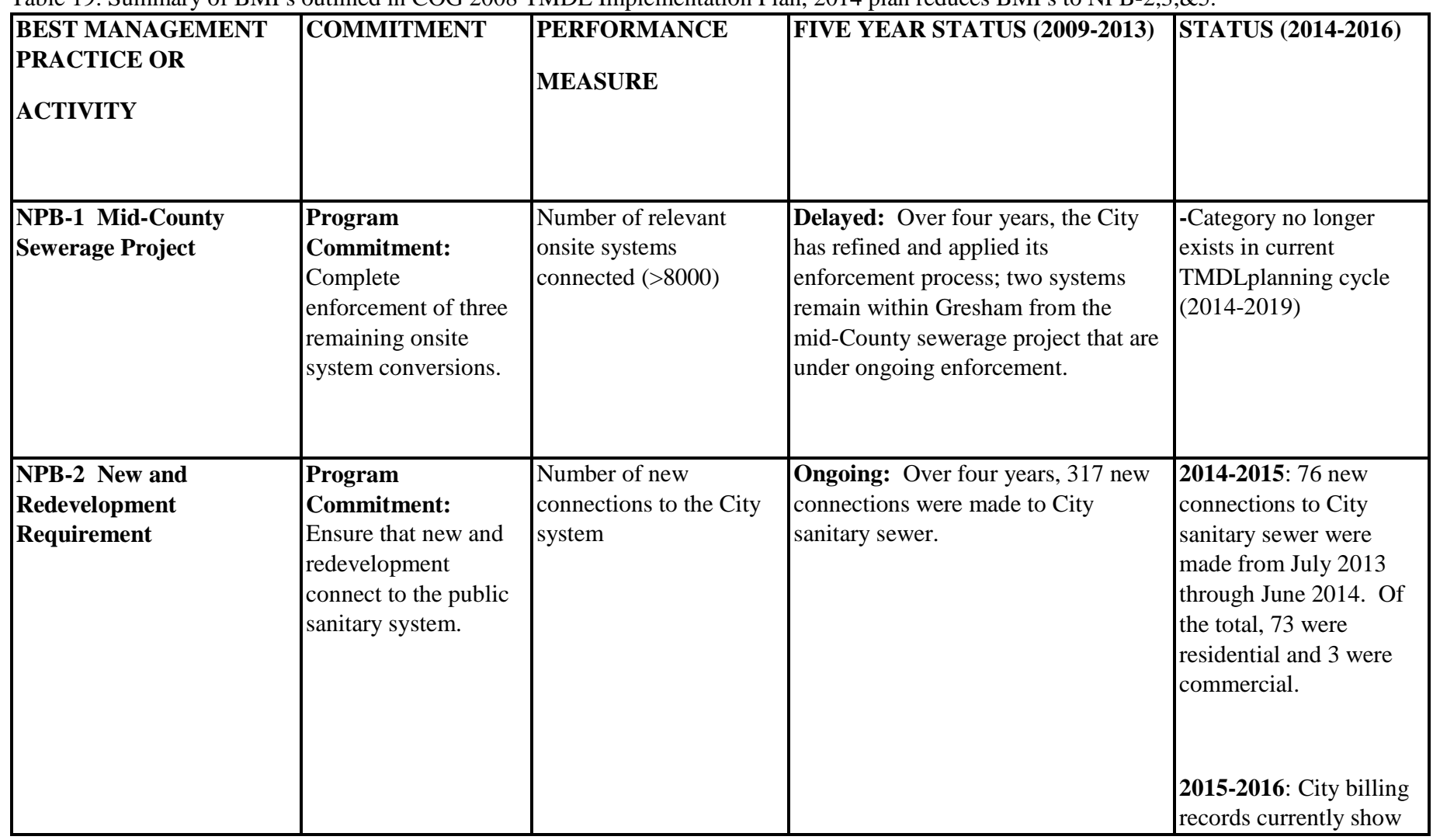




\begin{tabular}{|c|c|c|c|c|}
\hline & & & & $\begin{array}{l}24,155 \text { active and } \\
\text { inactive accounts, up } \\
\text { from } 24,104 \text { in the } \\
\text { previous year. Code } \\
\text { requires new and } \\
\text { redevelopment to hook } \\
\text { up to the city system if } \\
\text { a system exists within } \\
300 \text { feet. }\end{array}$ \\
\hline $\begin{array}{l}\text { NPB-3 Require Failed } \\
\text { Systems to Connect to } \\
\text { Public System }\end{array}$ & $\begin{array}{l}\text { Program } \\
\text { Commitment: } \\
\text { Ensure that failing } \\
\text { onsite systems are } \\
\text { replaced by } \\
\text { connection to City } \\
\text { system, where City } \\
\text { system is available. }\end{array}$ & $\begin{array}{l}\text { Number of onsite } \\
\text { properties that connect } \\
\text { to public system }\end{array}$ & $\begin{array}{l}\text { Ongoing: Over four years, seven } \\
\text { septic systems were } \\
\text { decommissioned, and six of those } \\
\text { hooked up to the City sanitary } \\
\text { system. (The remaining one was at a } \\
\text { demolished home.) One cesspool } \\
\text { was decommissioned and resulted in } \\
\text { an additional hookup to City } \\
\text { sanitary. }\end{array}$ & $\begin{array}{l}\text { 2014-2015: Two onsite } \\
\text { systems connected } \\
\text { 2015-2016: County } \\
\text { records show that } 3 \\
\text { tanks were } \\
\text { decommissioned in } \\
\text { Gresham. }\end{array}$ \\
\hline NPB-4 Onsite Survey & $\begin{array}{l}\text { Program } \\
\text { Commitment: } \\
\text { Determine location } \\
\text { of onsite systems } \\
\text { within City } \\
\text { boundaries as of } \\
2008\end{array}$ & $\begin{array}{l}\text { List of properties that } \\
\text { have onsite systems }\end{array}$ & $\begin{array}{l}\text { Ongoing: For the five-year report, a } \\
\text { map was created of all addresses that } \\
\text { are billed for stormwater or water, } \\
\text { but not for wastewater. This adds } \\
\text { spatial detail to the lists created bi- } \\
\text { ennially. }\end{array}$ & $\begin{array}{l}\text {-Category no longer } \\
\text { exists in current } \\
\text { TMDLplanning cycle } \\
(2014-2019)\end{array}$ \\
\hline $\begin{array}{l}\text { NPB-5 Ensure Spills } \\
\text { from Private Piped } \\
\text { Systems are Resolved }\end{array}$ & $\begin{array}{l}\text { Program } \\
\text { Commitment: } \\
\text { Respond to reports of } \\
\text { private system spills } \\
\text { to ensure prompt } \\
\text { cleanup and repair }\end{array}$ & $\begin{array}{l}\text { Number of failures } \\
\text { reported, and outcome }\end{array}$ & $\begin{array}{l}\text { Ongoing: Over the four years, a } \\
\text { total of } 10 \text { reports of private } \\
\text { discharges of human waste were } \\
\text { received, and the City provided a } \\
\text { response to ensure the wastes were } \\
\text { cleaned up; and wrote enforcement } \\
\text { letters and conducted local outreach } \\
\text { as appropriate to minimize future } \\
\text { such discharges. }\end{array}$ & $\begin{array}{l}\text { 2014-2015: Private } \\
\text { owner found to be } \\
\text { illegally discharging } \\
\text { RV waste into the } \\
\text { stormwater system. } \\
\text { The issue was remedied } \\
\text { by the Code } \\
\text { Enforcement } \\
\text { Department. } \\
\\
\mathbf{2 0 1 5 - 2 0 1 6 : ~ T w o ~ m i n o r ~} \\
\text { overflows were } \\
\text { reported on private } \\
\text { property and required } \\
\text { the owner to clean. No } \\
\text { threat to the city } \\
\text { stormwater system. }\end{array}$ \\
\hline
\end{tabular}




\section{Clackamas County/ Happy Valley}

NPDES (MS4) Background

Clackamas County is comprised of both urban and rural land uses. Within Johnson Creek the county is responsible for regulating surface water discharges to 1,480 acres of MS4s (4\% of the watershed), all of which are located in the Portland metro region of Clackamas County Service District no.1 (CCSD\#1). The developed area of the City of Happy Valley lies within CCSD\#1, and the remainder of the city will be annexed into CCSD\#1 as it is developed (WES, 2011).

Following the EPA stormwater rule in the early 1990s DEQ required six jurisdictions within Oregon to apply for and obtain an NPDES MS4 permit. Clackamas County was one of the six jurisdictions selected. Clackamas County along with 10 copermittees, including City of Milwaukie, prepared SWMPs in 1993, and obtained a joint MS4 permit in 1995. The SWMP was subsequently revised in 2000, 2006, and most recently in 2012 (WES, 2016). Major revisions to the 1993 SWMP includes the addition of performance measures in the 2006 SWMP, and updated performance measures in the 2012 SWMP. The County updated received their most recent NPDES MS4 permit on March 16, 2012, which expired March 1, 2017. The County is currently operating under their 2012 SWMP during the permit renewal process. A summary of activities implemented by the County to address bacterial discharges to Johnson Creek, and their annual progress for the years 2010-2016, can be found in the table below (Table 20). 
NPDES (MS4) Activities

Table 20. Summary of annual BMP implementation progress for CCSD\#1 from 2010-2016.

\begin{tabular}{|c|c|c|c|}
\hline $\begin{array}{c}\text { BEST } \\
\text { MANAGEMENT } \\
\text { PRACTICES } \\
\text { (BMPs) }\end{array}$ & GOALS & $\begin{array}{l}\text { REPORTING } \\
\text { ELEMENTS }\end{array}$ & STATUS \\
\hline $\begin{array}{l}\text { Respond to reports } \\
\text { involving illicit } \\
\text { discharges }\end{array}$ & $\begin{array}{l}\text { 1. Respond to reports involving } \\
\text { illicit discharges within two } \\
\text { weeks. }\end{array}$ & $\begin{array}{l}\text { 1. Number of alleged } \\
\text { illicit discharges } \\
\text { reported each year. } \\
\text { 2. Number of illicit } \\
\text { discharges controlled }\end{array}$ & $\begin{array}{l}\text { CCSD\#1 } \\
\text { 2010-2011: NA } \\
\text { 2011-2012: 1. } 9 \text { illicit discharges reported 2. } 7 \text { illicit } \\
\text { discharges were controlled, sources of the remaining } \\
\text { two couldn't be identified due to only a brief } \\
\text { duration of flow. } \\
\text { 2012-2013: 1. } 6 \text { illicit discharges reported and } 5 \\
\text { confirmed 2. } 4 \text { of the } 5 \text { discharges were controlled. } \\
\text { The source of the } 5^{\text {th }} \text { couldn't be identified but } \\
\text { stopped on its own. } \\
\text { 2013-2014: 1. } 6 \text { illicit discharges reported and } 6 \\
\text { confirmed 2. All } 6 \text { illicit discharges traced to the } \\
\text { source and controlled. } \\
\text { 2014-2015: } 1.7 \text { illicit discharges reported and } \\
\text { confirmed 2. } 7 \text { Illicit discharge controlled. } \\
\text { 2015-2016: 1. } 11 \text { illicit discharges reported and } 2 \\
\text { confirmed 2. Both illicit discharges controlled } \\
\text { (cross connection to sewer system from Mcdonalds } \\
\text { at 11899 SE Sunnyside and illicit discharge of meat } \\
\text { remnants from refrigerated trailer to storm sewer at } \\
\text { 15547 SE Piazza Ave) }\end{array}$ \\
\hline
\end{tabular}




\begin{tabular}{|c|c|c|c|}
\hline & & & $\begin{array}{l}\text { 2014-2015: } 32 \text { major outfalls inspected once during } \\
\text { summer. 2. } 1 \text { illicit discharge detected and } \\
\text { controlled (pavement washing from compost). } \\
\text { 2015-2016: 1. } 32 \text { major outfalls inspected once } \\
\text { during summer. 2. No illicit discharge detected }\end{array}$ \\
\hline $\begin{array}{l}\text { Control Infiltration } \\
\text { and Cross } \\
\text { Connections to the } \\
\text { Stormwater } \\
\text { Conveyance System }\end{array}$ & $\begin{array}{l}\text { 1. Eliminate any sanitary } \\
\text { discharges to the system }\end{array}$ & $\begin{array}{l}\text { 1. Number of cross- } \\
\text { connections/ sanitary } \\
\text { discharges identified. } \\
\text { 2. The number and } \\
\text { type of inspections } \\
\text { performed, abatement } \\
\text { actions and } \\
\text { enforcement actions } \\
\text { taken. }\end{array}$ & $\begin{array}{l}\text { CCSD\#1 } \\
\text { 2010-2011: None found } \\
\text { 2011-2012: } 1 \text { found and corrected. } \\
\text { 2012-2013: None found } \\
\text { 2013-2014: None found } \\
\text { 2014-2015: No cross connections/sanitary seepage } \\
\text { found. } \\
\text { 2015-2016: } 1 \text { cross connection found in CCSD\#1, } \\
\text { no enforcement actions. }\end{array}$ \\
\hline
\end{tabular}




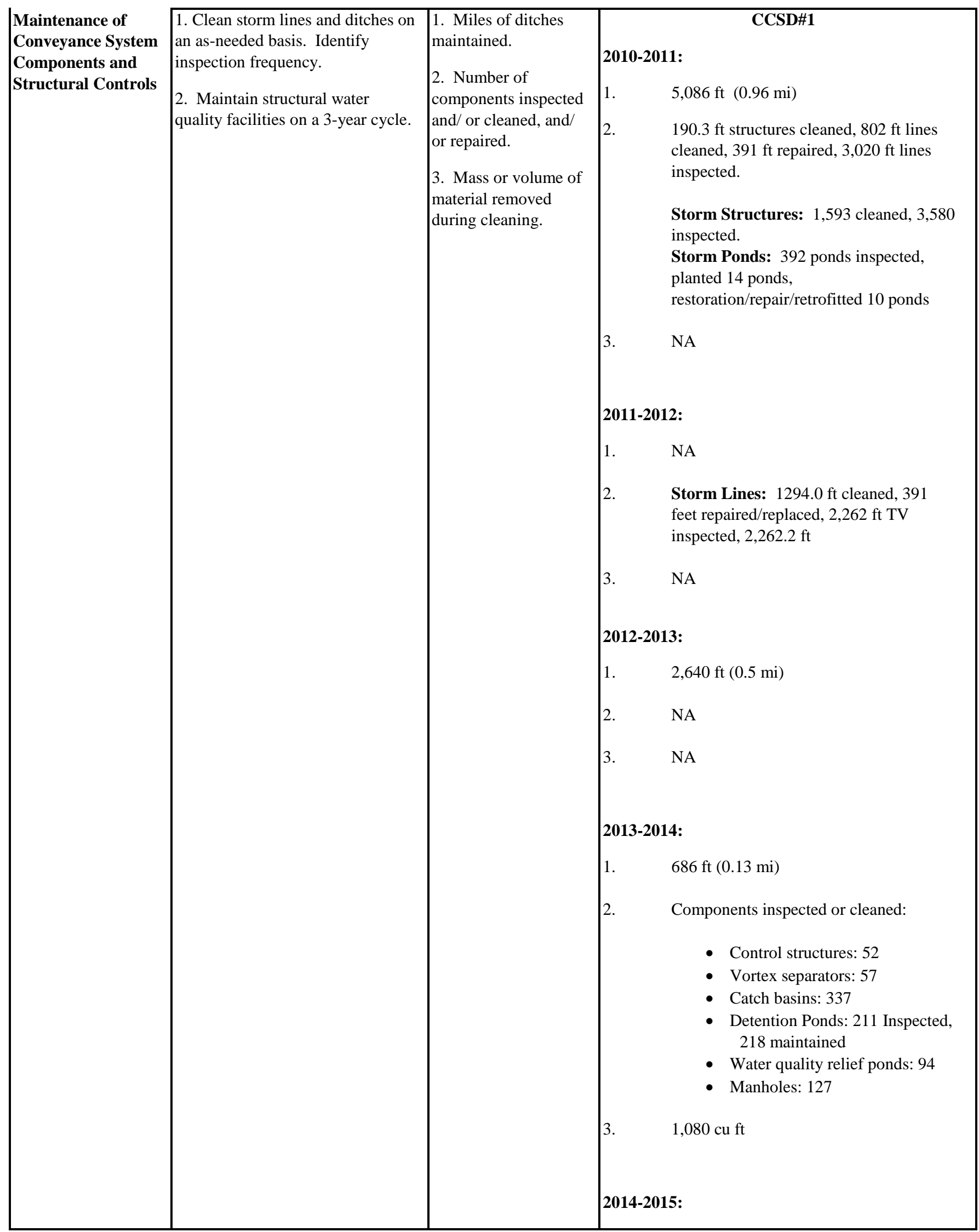




\begin{tabular}{|c|c|c|c|}
\hline & & & 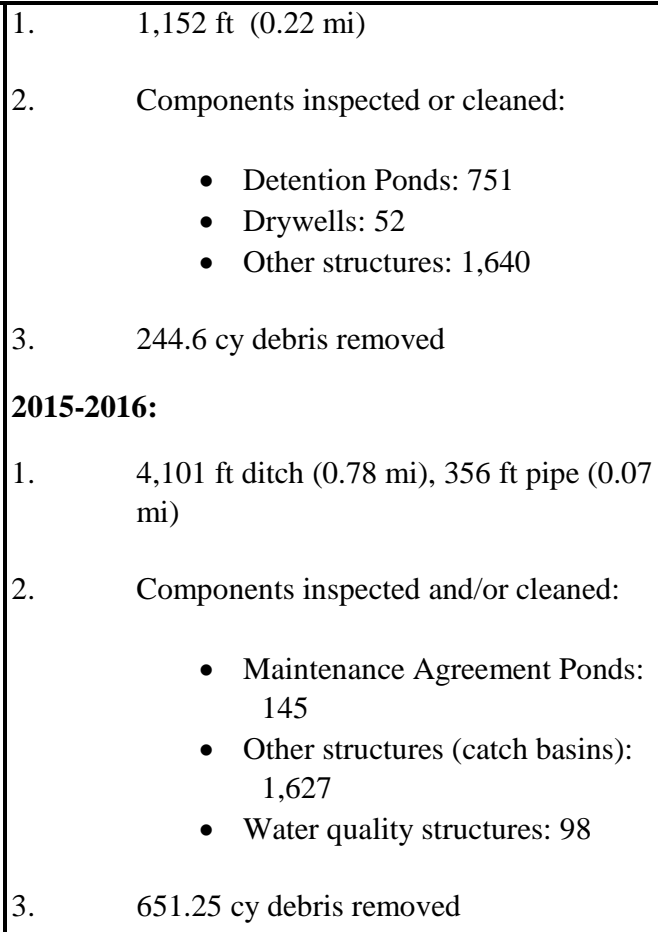 \\
\hline $\begin{array}{l}\text { Conduct Catch } \\
\text { Basin Cleaning and } \\
\text { Maintenance }\end{array}$ & $\begin{array}{l}\text { 1. Clean } 15 \% \text { of District owned } \\
\text { and/ or operated catch basins each } \\
\text { year } \\
\text { 2. Schedule repair or replacement } \\
\text { of catch basins based on inspection } \\
\text { result }\end{array}$ & $\begin{array}{l}\text { 1. Percent catch } \\
\text { basins cleaned per } \\
\text { year (District owned) } \\
\text { 2. Volume of debris } \\
\text { removed. }\end{array}$ & \begin{tabular}{|ll} 
& CCSD\#1 \\
2010-2011: NA & \\
2011-2012: NA & \\
2012-2013: $1.10 \%$ & 2. NA \\
2013-2014: $1.3 .4 \%$ & 2. NA \\
2014-2015: $1.4 .6 \%$ & 2. 148.83 cy material \\
2015-2016: $1.15 .3 \%$ 2. 23.5 cy material
\end{tabular} \\
\hline \begin{tabular}{|l} 
Sizing Tool \\
Development to \\
Address Hydro- \\
modification
\end{tabular} & $\begin{array}{l}\text { 1. Develop a simplified tool for } \\
\text { development engineers to easily } \\
\text { size LID BMPs to address the } \\
\text { duration of elevated flow levels in } \\
\text { addition to addressing flow } \\
\text { volumes and peaks. With } \\
\text { developed land increasing storm } \\
\text { runoff is expected to increase and } \\
\text { facility capacities will therefore, } \\
\text { need to be updated. }\end{array}$ & $\begin{array}{l}\text { 1. Net impervious } \\
\text { area treated by LID } \\
\text { (acres). } \\
\text { 2. Number of } \\
\text { applications submitted } \\
\text { using tool. }\end{array}$ & $\begin{array}{l}\text { CCSD\#1 } \\
\text { 2010-2011: NA } \\
\text { 2011-2012: NA } \\
\text { 2012-2013: 1. } 19.55 \text { ac 2. } 3 \text { detention ponds } \\
\text { 2013-2014: 1. 3,500 sq ft (0.08 ac) 2. } 1 \text { application } \\
\text { 2014-2015: 1. } 0 \text { ac } 2.1 \text { application } \\
\text { 2015-2016: 1. } 11.53 \text { ac } 2.3 \text { applications }\end{array}$ \\
\hline $\begin{array}{l}\text { Regulation of } \\
\text { Onsite Sewage } \\
\text { Disposal System }\end{array}$ & $\begin{array}{l}\text { 1. Investigate the suspected septic } \\
\text { problems or complaints on the } \\
\text { same day a notice is received. }\end{array}$ & $\begin{array}{l}\text { 1. Permits issued. } \\
\text { 2. Inspections } \\
\text { 3. Septic system } \\
\text { violations. }\end{array}$ & \begin{tabular}{|c|} 
County Wide \\
2010-2011: 1. 490 2. 734 3. 74 4. 0 5. NA \\
2011-2012: 1. 501 2. 533 3. 39 4. 4 5. 332
\end{tabular} \\
\hline
\end{tabular}




\begin{tabular}{|c|c|c|c|}
\hline & & $\begin{array}{l}\text { 4. Enforcement } \\
\text { actions } \\
\text { 5. Repairs } \\
\text { IP=Implementation } \\
\text { Plan }\end{array}$ & $\begin{array}{l}\text { 2012-2013: NA } \\
\text { 2013-2014: Addressed in TMDL IP } \\
\text { 2014-2015: Addressed in TMDL IP } \\
\text { 2015-2016: Addressed in TMDL IP }\end{array}$ \\
\hline Street Sweeping & $\begin{array}{l}\text {-Sweep curbed streets once per } \\
\text { month. }\end{array}$ & $\begin{array}{l}\text { 1. Number of miles } \\
\text { that were swept. } \\
\text { 2. Volume of material } \\
\text { removed during } \\
\text { sweeping (cubic } \\
\text { yards) }\end{array}$ & $\begin{array}{l}\text { Happy Valley/CCSD\#1 } \\
\text { 2010-2011: 1. 1,989 mi 2. } 239 \text { cy } \\
\text { 2011-2012: 1. } 2,688 \text { mi 2. } 285 \text { cy } \\
\text { 2012-2013: NA } \\
\text { 2013-2014: NA } \\
\text { 2014-2015: } 1.1,000 \text { mi 2. } 497 \text { yards } \\
\text { 2015-2016: } 1.1,800 \text { mi 2. } 900 \text { yards }\end{array}$ \\
\hline $\begin{array}{l}\text { Detention Pond } \\
\text { Retrofit Program }\end{array}$ & $\begin{array}{l}\text { 1. Retrofit existing ponds to better } \\
\text { meet existing stormwater goals. } \\
\text { Stormwater management standards } \\
\text { have changed four times since the } \\
1993 \text { stormwater requirements, } \\
\text { these older facilities (pre 1995) are } \\
\text { therefore, the primary target. }\end{array}$ & $\begin{array}{l}\text { 1. Number, type and } \\
\text { location of retrofit }\end{array}$ & $\begin{array}{l}\text { CCSD\#1 } \\
\text { 2010-2011: NA } \\
\text { 2011-2012: } 6 \text { ponds retrofitted, } 7 \text { restored, } 20 \\
\text { repaired, 848 plantings. } \\
\text { 2012-2013: None in Johnson Creek } \\
\text { 2013-2014: } 1 \text { pond retrofit in Johnson Creek } \\
\text { 2014-2015: } 2 \text { pond retrofits (50\% complete) } \\
\text { 2015-2016: Completed } 2 \text { pond retrofits from } \\
\text { previous year. }\end{array}$ \\
\hline
\end{tabular}

\section{TMDL Implementation Plan Background}

Clackamas County submitted their TMDL Implementation Plan to DEQ in June of 2009.

The plan was subsequently revised and approved by DEQ in January of 2011, at which point the County began implementation of their TMDL program. The County submitted a 5 year review template to DEQ in June of 2013 highlighting the success and limitations of their TMDL management strategies. No revisions to the 2011 TMDL Implementation Plan were reported following the 5 year review (WES, 2014). Major BMPs utilized by the County to prevent bacteria 
from entering the stream includes management of: dead animals, pet waste, septic systems, and illegal dumping. Annual progress of BMPs used by the County to address nonpoint sources of bacteria entering Johnson Creek for the years 2013-2016, can be found below (Table 21).

\section{TMDL Activities}

Table 21. Annual progress of BMPs addressed in CCSD\#1 TMDL Implementation Plan to reduce E. coli loading. Data collected from CCSD\#1 2013-2016 TMDL annual reports.

\begin{tabular}{|c|c|c|c|c|}
\hline $\begin{array}{c}\text { BEST } \\
\text { MANAGEMENT } \\
\text { PRACTICES (BMPs) }\end{array}$ & HOW IMPLEMENTED & $\begin{array}{l}\text { REPORTING } \\
\text { ELEMENTS }\end{array}$ & $\begin{array}{c}\text { FISCAL } \\
\text { ANALYSIS }\end{array}$ & STATUS \\
\hline $\begin{array}{l}\text { Dead Animal } \\
\text { Management }\end{array}$ & $\begin{array}{l}\text { Personnel from Clackamas County } \\
\text { Road Dept. and from Happy } \\
\text { Valley’s Public Works } \\
\text { Maintenance Dept. collect and } \\
\text { properly dispose of large dead } \\
\text { animals on full-service roads. } \\
\text { (Clackamas County \& Happy } \\
\text { Valley) }\end{array}$ & $\begin{array}{l}\text { 1. Number of animals } \\
\text { removed annually. }\end{array}$ & Currently funded & $\begin{array}{l}\text { Happy Valley } \\
\text { 2013-2014: } 12 \text { dead } \\
\text { animals removed } \\
\text { 2014-2015: } 15 \text { dead } \\
\text { animals removed } \\
\text { 2015-2016: } 14 \text { dead } \\
\text { animals removed }\end{array}$ \\
\hline $\begin{array}{c}\text { Pet Waste } \\
\text { Management/Public } \\
\text { Education }\end{array}$ & $\begin{array}{l}\text { Public education to pet owners } \\
\text { through a variety of sources. } \\
\text { Maintain educational signs and } \\
\text { provide dog waste bag dispensers } \\
\text { in parks. (Clackamas County \& } \\
\text { Happy Valley) }\end{array}$ & $\begin{array}{l}\text { 1. Track number of bags } \\
\text { taken from dispensers each } \\
\text { year. Track the number of } \\
\text { website "hits" }\end{array}$ & Currently funded & $\begin{array}{l}\text { County Wide } \\
\text { 2013-2014: } 750 \text { doggie } \\
\text { bags were used in the } \\
\text { reporting year in Boones } \\
\text { Ferry Park. No } \\
\text { information for website } \\
\text { hits. } \\
\text { 2014-2015: } \\
\text { - } \\
\text { Distributed } \\
\text { approximately } \\
\text { 10,000 pet } \\
\text { waste collection } \\
\text { bags at multiple } \\
\text { public events to } \\
\text { educated pet } \\
\text { owners } \\
\text { Public } \\
\text { education on } \\
\text { pet waste } \\
\text { management } \\
\text { appeared on the }\end{array}$ \\
\hline
\end{tabular}




\begin{tabular}{|c|c|c|c|c|}
\hline & & & & $\begin{array}{l}\text { WES website } \\
\text { (12,804 hits) } \\
\text { 700 doggie bags } \\
\text { pulled from } \\
\text { doggie bag } \\
\text { dispenser } \\
\text { placed near boat } \\
\text { ramp/river front } \\
\text { area of Hebb } \\
\text { Park } \\
\text { 2015-2016: } \\
\text { Distributed } \\
\text { approximately } \\
\text { 10,000 pet } \\
\text { waste collection } \\
\text { bags at multiple } \\
\text { public events to } \\
\text { educated pet } \\
\text { owners } \\
\text { - } \\
\text { Public } \\
\text { education on } \\
\text { pet waste } \\
\text { management } \\
\text { appeared on the } \\
\text { WES website } \\
\text { (12,585 hits) } \\
\text { 300 doggie bags } \\
\text { pulled from } \\
\text { doggie bag } \\
\text { dispenser } \\
\text { placed near boat } \\
\text { ramp/river front } \\
\text { area of Hebb } \\
\text { Park }\end{array}$ \\
\hline $\begin{array}{l}\text { Septic System } \\
\text { Management }\end{array}$ & $\begin{array}{l}\text { Respond to reports of failing } \\
\text { systems; work with homeowner to } \\
\text { set a timeline for repair. }\end{array}$ & $\begin{array}{l}\text { 1. Track number of failures } \\
\text { that need repair permits. } \\
\text { 2. Number of failures that } \\
\text { need maintenance. } \\
\text { 3. Number of enforcement } \\
\text { actions }\end{array}$ & Currently funded & 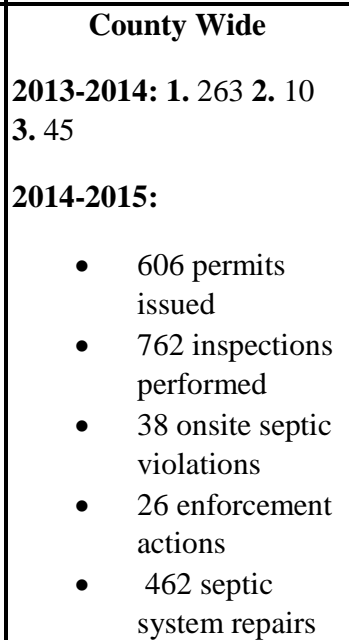 \\
\hline
\end{tabular}




\begin{tabular}{|c|c|c|c|c|}
\hline & & & & \begin{tabular}{|ll}
$\bullet$ & 112 major \\
& repairs \\
• & 350 minor \\
& repairs \\
2015-2016: & \\
Willamette Watershed \\
• $\quad 494$ permits \\
- $\quad$ issued \\
1,235 \\
inspections \\
38 onsite septic \\
violations \\
19 enforcement \\
actions
\end{tabular} \\
\hline $\begin{array}{c}\text { Connect To Sanitary } \\
\text { Sewer }\end{array}$ & $\begin{array}{l}\text { Provide sanitary sewer service to } \\
\text { properties currently within its } \\
\text { CCSD\#1 Service District } \\
\text { boundary and properties that come } \\
\text { into the CCSD\#1 Boundary via } \\
\text { annexation to the District itself or } \\
\text { into a city which the District } \\
\text { serves. }\end{array}$ & $\begin{array}{l}\text { 1. Track number of } \\
\text { connections. } \\
\text { 2. Estimate pollutant load } \\
\text { reduction. }\end{array}$ & $\begin{array}{l}\text { Current annexations } \\
\text { funded. }\end{array}$ & \begin{tabular}{l}
\multicolumn{1}{|c}{ County Wide } \\
2013-2014: 1. 525 \\
sanitary sewer \\
connections in CCSD\#1, \\
47 in North Clackamas \\
Revitalization Area \\
(NCRA) converted (326 \\
of 929) 2. 78\% once \\
remaining systems in \\
NCRA connected to \\
sanitary line. \\
2014-2015: 1.461 \\
sanitary sewer \\
connections in CCSD\#1, \\
27 in NCRA converted \\
(363 of 929) $2.78 \%$ once \\
remaining systems in \\
NCRA connected to \\
sanitary line. \\
2015-2016: 1.551 \\
sanitary sewer \\
connections in CCSD\#1, \\
41 in NCRA converted \\
(404 of 929) $2.78 \%$ once \\
remaining systems in \\
NCRA connected to \\
sanitary line.
\end{tabular} \\
\hline $\begin{array}{l}\text { Illegal Dumping } \\
\text { Management }\end{array}$ & $\begin{array}{l}\text { Implement Clackamas County’s } \\
\text { Dump Stoppers Program and City } \\
\text { of Happy Valley illegal dumping } \\
\text { ordinance. Provide public } \\
\text { education related to illegal }\end{array}$ & $\begin{array}{l}\text { 1. Track waste removed } \\
\text { through Dump Stoppers } \\
\text { Program. } \\
\text { 2. Track number of } \\
\text { persons/year who complete }\end{array}$ & Currently funded & $\begin{array}{l}\text { Happy Valley } \\
\text { 2013-2014: } 8 \text { illegal } \\
\text { dumps, } 3 \text { enforcement } \\
\text { actions taken. } \\
\text { 2014-2015: }\end{array}$ \\
\hline
\end{tabular}




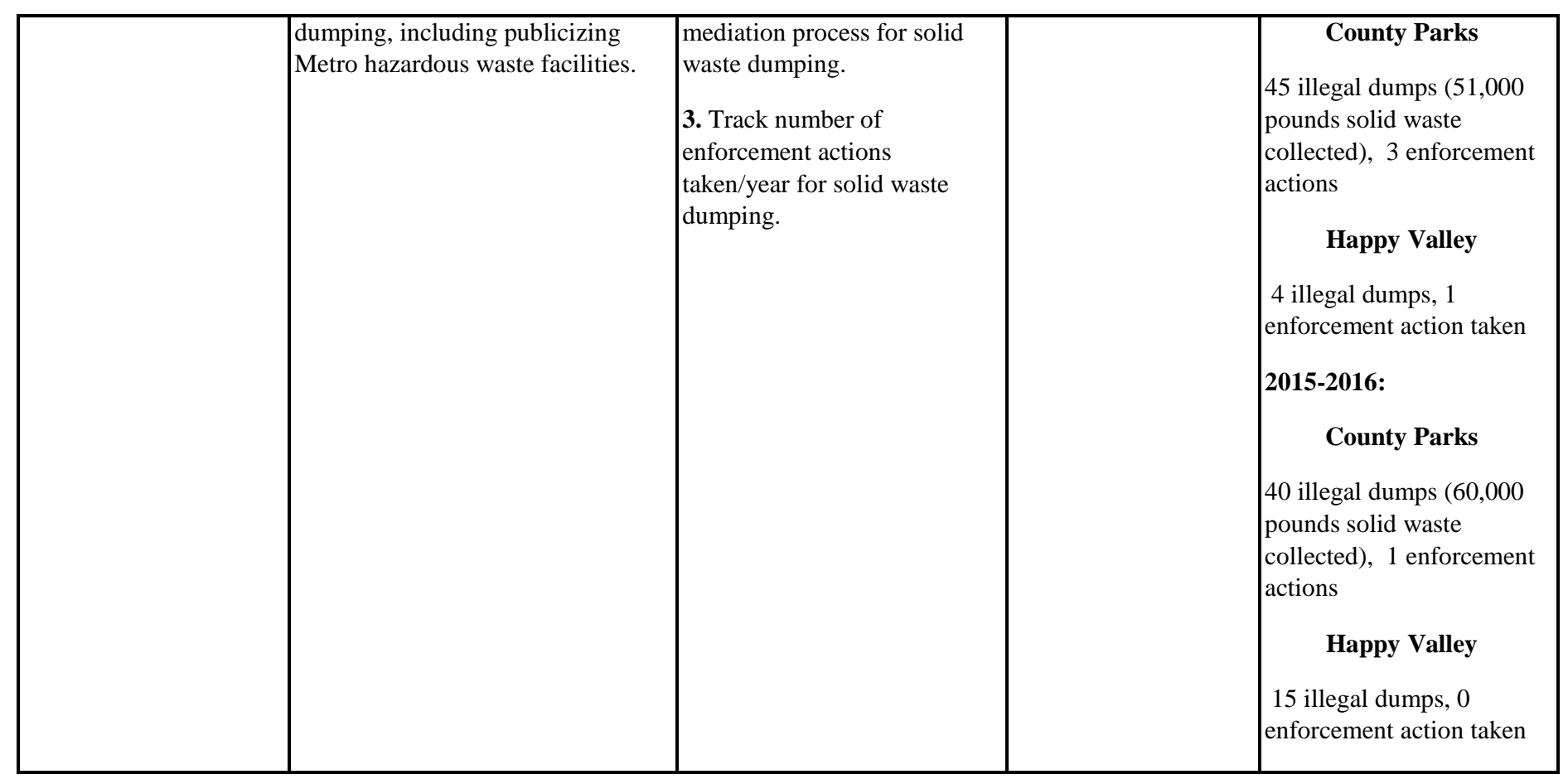

Acronyms in Table:

1. North Clackamas Revitalization Area (NCRA)

2. Watershed Environment Services (WES) 


\section{City of Milwaukie}

The City of Milwaukie is located south of Portland within Clackamas County, and borders Johnson Creek at its mouth near SE 17th Ave (Figure 4). The current population (2017) is approximately 20,291 individuals. Milwaukie was listed as a DMA by ODEQ in the 2006 Bacteria TMDL for Johnson Creek and is designated as a Phase I MS4 Co-permittee along with Clackamas County, and Happy Valley. The city is responsible for managing bacterial discharges to the stream by adopting a SWMP as required by their NPDES (MS4) permit and for managing non-point bacterial sources by adopting a TMDL implementation plan. TMDL strategies for City of Milwaukie to address bacteria are relatively limited as the city has included management of storm runoff not discharging to an MS4 as part of their NPDES MS4 permit.

NPDES (MS4) Background

As a co-permittee of Clackamas County, City of Milwaukie, prepared its' first SWMP in 1993, and obtained a joint MS4 permit in 1995. Milwaukie’s 1993 SWMP had 5 major BMP categories including: illicit discharge controls, public education, structural and source controls, industrial controls, and construction controls (City of Milwaukie, 2006).

Milwaukie’s permit renewal during the second NPDES cycle was delayed due to concern from outside environmental parties regarding the lack of numeric limits for stormwater outfalls. Milwaukie's second NPDES permit was issued in 2004. New permit requirements in 2004, among other things, required more stringent monitoring and that a new SWMP be developed to include performance measures. The updated SWMP was submitted to and approved by DEQ in 2006. The city updated their SWMP again in 2011 and received their NPDES MS4 permit March 16, 2012, which expired March 1, 2017. The City is currently operating under their 2011 
SWMP during the permit renewal process. A summary of activities implemented by the city to address bacterial discharges to Johnson Creek, and their annual progress for the years 20052016, can be found in the table below (Table 22).

\section{NPDES (MS4) Activities}

Table 22. Summary of BMPs implemented by COM from 2005-2016 as part of their NPDES stormwater management program to address potential sources of bacterial discharge to Johnson Creek.

\begin{tabular}{|c|c|c|c|}
\hline $\begin{array}{c}\text { BEST } \\
\text { MANAGEMENT } \\
\text { PRACTICES } \\
\text { (BMPs) }\end{array}$ & GOALS & $\begin{array}{l}\text { REPORTING } \\
\text { ELEMENTS }\end{array}$ & STATUS \\
\hline $\begin{array}{l}\text { Implement Illicit } \\
\text { Discharges and } \\
\text { Detection } \\
\text { Elimination } \\
\text { Program (IDDE) }\end{array}$ & $\begin{array}{l}\text { Remove all identified illicit } \\
\text { discharges in conjuncture with the } \\
\text { City’s IDDE SOP } \\
\text {-Track and record all identified } \\
\text { illicit discharges and how such } \\
\text { discharges were removed. } \\
\text { (Program is complaint based) }\end{array}$ & $\begin{array}{l}\text { - Number, location, } \\
\text { resolution and } \\
\text { enforcement activities } \\
\text { for any identified } \\
\text { illicit discharge (ID). }\end{array}$ & $\begin{array}{l}\text { 2005-2006: NA } \\
\text { 2006-2007: NA } \\
\text { 2007-2008: NA } \\
\text { 2008-2009: NA } \\
\text { 2009-2010: NA } \\
\text { 2010-2011: NA } \\
\text { 2011-2012: } 1 \text { ID (wastewater dumping from mobile } \\
\text { coffee vendor), public works cleaned catch basin } \\
\text { and citation was issued. } \\
\text { 2012-2013: no bacterial wastewater ID identified } \\
\text { 2013-2014: Cat litter dumped in storm catch basin, } \\
\text { enforcement in progress. } \\
\text { 2014-2015: Buckets of wastewater dumped into } \\
\text { storm drain from unplumbed food cart, storm drain } \\
\text { cleaned and citation issued. } \\
\text { 2015-2016: no bacterial ID identified }\end{array}$ \\
\hline $\begin{array}{l}\text { Conduct Annual } \\
\text { Dry Weather Field } \\
\text { Screening }\end{array}$ & $\begin{array}{l}\text {-Conduct annual dry-weather illicit } \\
\text { discharge inspections for all } \\
\text { priority outfalls. }\end{array}$ & $\begin{array}{l}\text {-Monitoring sites } \\
\text { inspected }\end{array}$ & $\begin{array}{l}\text { City Wide } \\
\text { 2005-2006: } 64 \text { sites, none found, no follow up } \\
\text { 2006-2007: } 64 \text { sites, none found, no follow up }\end{array}$ \\
\hline
\end{tabular}




\begin{tabular}{|c|c|c|c|}
\hline & $\begin{array}{l}\text {-Conduct investigations on all } \\
\text { suspected non-permissible } \\
\text { discharges. } \\
\text {-Develop pollutant parameter } \\
\text { action levels to assist in the } \\
\text { identification of non-permissible } \\
\text { discharges by November 1, } 2011 . \\
\text {-Annually maintain a map of dry } \\
\text { weather screening priority } \\
\text { locations (i.e., priority outfalls). }\end{array}$ & $\begin{array}{l}\text { - Number potential } \\
\text { illicit discharge } \\
\text { (ID)/identified } \\
\text {-Follow up action } \\
\text { (none if potential } \\
\text { illicit discharge is } \\
\text { dismissed) }\end{array}$ & $\begin{array}{l}\text { 2007-2008: } 68 \text { sites, none found, no follow up } \\
\text { 2008-2009: } 64 \text { sites, } 0 \text { ID, no follow up } \\
\text { 2009-2010: } 64 \text { sites, } 1 \text { outfall with flow, linked to } \\
\text { residential irrigation } \\
\text { 2010-2011: } 64 \text { sites, } 4 \text { sites with flow, no follow up } \\
\text { 2011-2012: } 64 \text { sites, } 3 \text { potential ID, no bacterial ID } \\
\text { identified } \\
\text { 2012-2013: } 26 \text { sites, } 6 \text { potential ID, no bacterial ID } \\
\text { identified } \\
\text { 2013-2014: } 26 \text { sites, } 11 \text { potential ID, no bacterial ID } \\
\text { identified } \\
\text { 2014-2015: } 26 \text { sites, } 7 \text { potential ID, no bacterial ID } \\
\text { identified } \\
\text { 2015-2016: } 26 \text { sites, } 3 \text { potential ID, no bacterial ID }\end{array}$ \\
\hline \begin{tabular}{|l} 
Conduct \\
Stormwater \\
Conveyance System \\
Cleaning and \\
Maintenance
\end{tabular} & $\begin{array}{l}\text { Inspect stormwater system } \\
\text { conveyance components (i.e., } \\
\text { manholes, culverts and ditches) } \\
\text { every two years and perform } \\
\text { maintenance based on inspection } \\
\text { results. }\end{array}$ & $\begin{array}{l}\text {-linear feet storm } \\
\text { main inspected each } \\
\text { year. } \\
\text { - volume of debris } \\
\text { removed } \\
\text { - conveyance system } \\
\text { repair efforts } \\
\text { conducted }\end{array}$ & 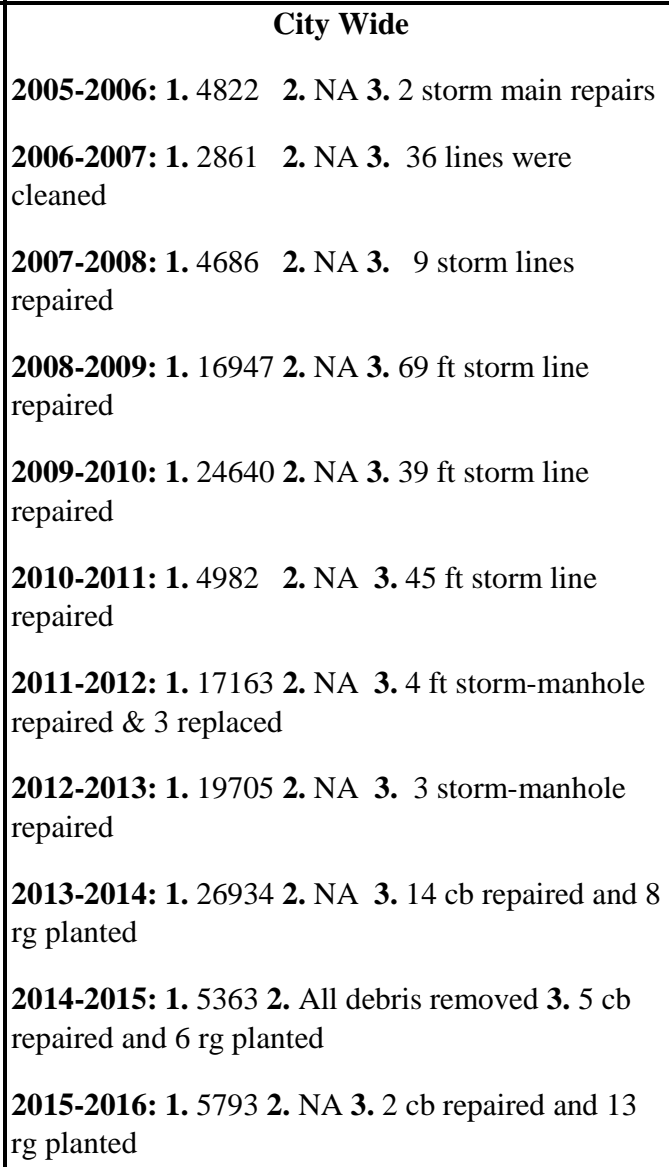 \\
\hline $\begin{array}{l}\text { Control Infiltration } \\
\text { and Cross } \\
\text { Connections to the }\end{array}$ & $\begin{array}{l}\text { - Investigate sanitary lines for } \\
\text { damage every five to six years. }\end{array}$ & $\begin{array}{l}\text {-Record whether cross } \\
\text { connections were } \\
\text { discovered during dry }\end{array}$ & 2005-2006: None found \\
\hline
\end{tabular}




\begin{tabular}{|c|c|c|c|}
\hline $\begin{array}{l}\text { Stormwater } \\
\text { Conveyance System }\end{array}$ & $\begin{array}{l}\text {-Remove all cross connections } \\
\text { discovered during dry weather } \\
\text { screening. }\end{array}$ & $\begin{array}{l}\text { weather investigation } \\
\text { and describe follow- } \\
\text { up activities }\end{array}$ & $\begin{array}{l}\text { 2006-2007: None found } \\
\text { 2007-2008: None found } \\
\text { 2008-2009: None found } \\
\text { 2009-2010: None found } \\
\text { 2010-2011: Sewer lateral connected to stormline at } \\
\text { 9696 SE Omark Dr., was corrected. } \\
\text { 2011-2012: None found } \\
\text { 2012-2013: None found } \\
\text { 2013-2014: None found } \\
\text { 2014-2015: None found } \\
\text { 2015-2016: None found }\end{array}$ \\
\hline $\begin{array}{l}\text { Private Water } \\
\text { Quality Facility } \\
\text { Maintenance } \\
\text { Program }\end{array}$ & $\begin{array}{l}\text {-Develop procedures to guide the } \\
\text { private facility maintenance } \\
\text { program by January 1, } 2013 . \\
\text {-Conduct a minimum of } 10 \text { onsite } \\
\text { inspections per year. }\end{array}$ & $\begin{array}{l}\text {-Track the number of } \\
\text { onsite private } \\
\text { stormwater quality } \\
\text { facility inspections } \\
\text { conducted annually. }\end{array}$ & $\begin{array}{l}\text { 2005-2006: NA } \\
\text { 2006-2007: NA } \\
\text { 2007-2008: NA } \\
\text { 2008-2009: NA } \\
\text { 2009-2010: NA } \\
\text { 2010-2011: NA } \\
\text { 2011-2012: NA } \\
\text { 2012-2013: None } \\
\text { 2013-2014: None } \\
\text { 2014-2015: None } \\
\text { 2015-2016: } 78 \text { private storm drains cleaned }\end{array}$ \\
\hline Street Sweeping & $\begin{array}{l}\text {-Sweep curbed streets once per } \\
\text { month. }\end{array}$ & $\begin{array}{l}\text {-Track number of } \\
\text { miles of sweeps per } \\
\text { year and volume of } \\
\text { debris removed (cubic } \\
\text { yards). }\end{array}$ & $\begin{array}{l}\text { City Wide } \\
\text { 2005-2006: 1. 3,356 mi 2.839 cy } \\
\text { 2006-2007: 1. 5,639 mi 2.1542 cy } \\
\text { 2007-2008: 1. 5,278 mi 2.1564 cy } \\
\text { 2008-2009: 1. 5,563 mi 2.988 cy } \\
\text { 2009-2010: } 1.5,255 \text { mi 2.1,526 cy } \\
\text { 2010-2011: 1. } 6,124 \text { mi 2.1,368 cy } \\
\text { 2011-2012: 1. 4,761 mi 2.2,357 cy } \\
\text { 2012-2013: 1. 4,457 mi 2.1,587 cy } \\
\text { 2013-2014: } 1.1,526 \text { mi 2.1704 cy } \\
\text { 2014-2015: } 1.1,057 \text { mi 2. } 1,465 \text { cy } \\
\text { 2015-2016: 1. } 1,605 \text { mi 2. } 2,043 \text { cy }\end{array}$ \\
\hline
\end{tabular}




\begin{tabular}{|c|c|c|c|}
\hline $\begin{array}{l}\text { Public Structural } \\
\text { Control Facility } \\
\text { Cleaning and } \\
\text { Maintenance }\end{array}$ & $\begin{array}{l}\text {-Inspect and maintain public water } \\
\text { quality facilities annually } \\
\text { (i.e. retention ponds, swales, } \\
\text { sediment vaults, pollution control } \\
\text { manholes, etc.) }\end{array}$ & $\begin{array}{l}\text {-Track the percent of } \\
\text { total structural } \\
\text { facilities inspected } \\
\text { and maintained each } \\
\text { year. } \\
\text {-Track the volume of } \\
\text { debris removed during } \\
\text { cleaning activities. }\end{array}$ & $\begin{array}{l}\text { City Wide } \\
\text { 2005-2006: 1. NA, 2. } 1.2 \text { cy from } 1 \text { vault and } 1 \text { yd } \\
\text { from } 1 \text { weir } \\
\text { 2006-2007: 1. NA, 2. } 4.5 \text { cy debris from } 2 \text { vaults } \\
\text { and 1.5 yd from } 1 \text { weir. } \\
\text { 2007-2008: 1. NA, 2. } 10 \text { yd debris from } 1 \text { pond, } 1.9 \\
\text { yards from } 2 \text { vaults, and } 1 \text { yd from } 1 \text { weir } \\
\text { 2008-2009: 1. NA, 2. } 6.52 \text { cy debris removed from } \\
\text { facilities } \\
\text { 2009-2010: 1. NA, 2. } 37.4 \text { cy debris removed from } \\
\text { facilities } \\
\text { 2010-2011: 1.NA, 2. } 13.8 \text { cy debris removed from } \\
\text { facilities } \\
\text { 2011-2012: 1. 75\% structures inspected, 2. NA } \\
\text { 2012-2013: 1. 100\% inspected 2. NA } \\
\text { 2013-2014: 1. } 100 \% \text { inspected and maintained } 2 . \\
\text { NA } \\
\text { 2014-2015: 1. } 100 \% \text { inspected and maintained } 2 . \\
\text { 15cy debris removed } \\
\text { 2015-2016: 1. } 100 \% \text { inspected and maintained } 2 . \\
\text { 37.2 cy debris removed }\end{array}$ \\
\hline $\begin{array}{l}\text { Catch basin } \\
\text { Cleaning and } \\
\text { Maintenance }\end{array}$ & $\begin{array}{l}\text {-Clean } 50 \% \text { of public catch basins } \\
\text { each year. } \\
\text {-Schedule repair or replacement of } \\
\text { catch basins based on inspection } \\
\text { results. }\end{array}$ & $\begin{array}{l}\text { - Track number of } \\
\text { catch basins cleaned } \\
\text { per year. } \\
\\
\text {-Track volume of } \\
\text { materials removed } \\
\text { (cubic yards) }\end{array}$ & 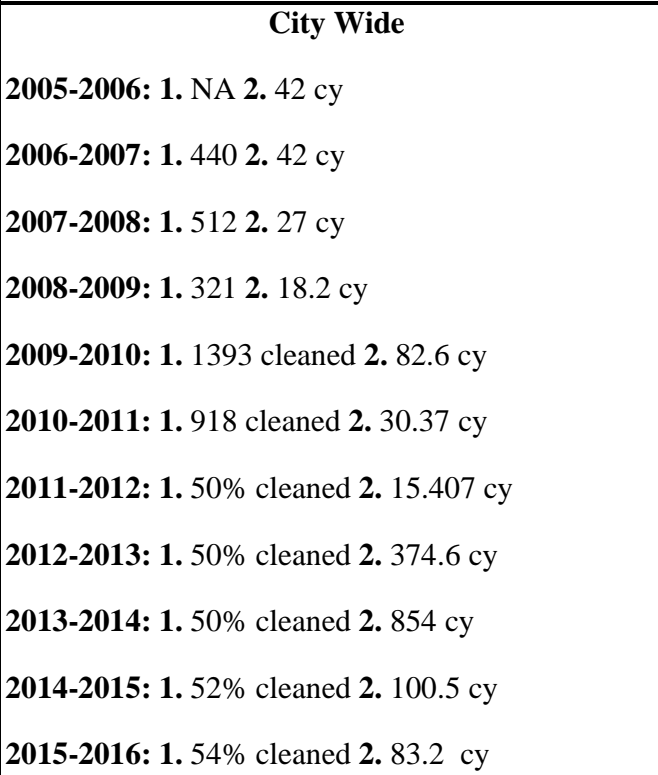 \\
\hline
\end{tabular}




\section{TMDL Implementation Plan Background}

Milwaukie submitted their TMDL implementation plan to DEQ in March of 2008 and began implementation of the program following approval by DEQ in July of 2009. The plan was subsequently revised in 2013 following the 5 year TMDL review period which requires DMA's to highlight the success and limitations of TMDL management strategies, and make updates to the TMDL implementation plan. The TMDL implementation plan was approved by DEQ in July of 2014, and the city began implementing their updated BMPs. For bacterial management the major TMDL strategies are providing educational outreach for proper septic system maintenance, replacing leaking septic systems, and extending sanitary sewer service area into rural regions. The 2014 TMDL implementation plan does not address bacteria. This is because between 2008 and 2011, major septic regions within the city were mapped and required to hook up to the municipal sewer if they were within the service boundary. Additionally public collection systems were constructed between 2008 and 2011 in the NE region of the city along with lift stations, to extend the municipal service region and to disconnect septic systems within the region (Table 23). 
Table 23. Summary of annual progress of TMDL activities for City of Milwaukie for 2009-2011. Following 2011 no TMDL projects/activities addressing bacteria were reported.

\begin{tabular}{|c|c|c|c|c|}
\hline BMP CATEGORY & $\begin{array}{l}\text { BEST MANAGEMENT } \\
\text { PRACTICES (BMPs) }\end{array}$ & GOALS & $\begin{array}{l}\text { REPORTING } \\
\text { ELEMENTS }\end{array}$ & STATUS \\
\hline \multirow[t]{3}{*}{$\begin{array}{l}\text { Private Sanitary } \\
\text { Waste Systems }\end{array}$} & $\begin{array}{l}\text { Extend public collection } \\
\text { systems to unincorporated } \\
\text { areas NE of the city. }\end{array}$ & $\begin{array}{l}230 \text { properties in } \\
\text { progress of being } \\
\text { connected to } \\
\text { municipal } \\
\text { sanitary sewer. }\end{array}$ & $\begin{array}{l}\text {-Number of properties } \\
\text { designated to have sewer } \\
\text { extended to their property }\end{array}$ & $\begin{array}{l}\text { 2008-2009: NA } \\
\text { 2009-2010: Public collection system } \\
\text { constructed to serve } 230 \text { properties. } \\
\text { 2010-2011: lift station constructed at SE } \\
55 \text { in JC to allow collection system to be } \\
\text { used, } 6 \text { properties connected. }\end{array}$ \\
\hline & Onsite Survey & $\begin{array}{c}\text { Map all } \\
\text { properties } \\
\text { currently using } \\
\text { onsite systems }\end{array}$ & $\begin{array}{l}\text {-Number of properties } \\
\text { using onsite systems }\end{array}$ & $\begin{array}{l}\text { 2008-2009: NA } \\
\text { 2009-2010: NA } \\
\text { 2010-2011: } 16 \text { properties mapped }\end{array}$ \\
\hline & $\begin{array}{l}\text { Require private systems } \\
\text { to connect to the public } \\
\text { system }\end{array}$ & $\begin{array}{c}\text { Require } 16 \\
\text { properties with } \\
\text { septic systems to } \\
\text { connect to the } \\
\text { municipal sewer } \\
\text { system }\end{array}$ & -Properties connected & $\begin{array}{l}\text { 2008-2009: NA } \\
\text { 2009-2010: NA } \\
\text { 2010-2011: } 2 \text { properties connected, the } \\
\text { remaining properties required to hook up } \\
\text { to the municipal sewer by Dec } 31,2011\end{array}$ \\
\hline
\end{tabular}




\section{Oregon Department of Agriculture}

\section{Background}

The Oregon Department of Agriculture (ODA) was listed as a DMA for the bacteria TMDL within Johnson Creek. As a result ODA must take necessary measures to achieve the $78 \%$ load reduction target. ODA is the lead agency responsible for regulating agriculture related activities. Within the Johnson Creek Watershed, ODA has jurisdiction over approximately 15\% of the watershed in the mid and upper regions of the watershed (Table 2) which falls within both Multnomah and Clackamas County (Multnomah, 2014) and (ODA, 2017). Following the passage of the 1993 Agricultural Water Quality Management Act (AgWQMA), ODA was tasked with implementing an Agricultural Water Quality Program, under which plans to prevent and control pollution of water bodies attributed to agricultural related activities would be enacted. ODA has a Memorandum of Agreement (MOA) with DEQ which formally acknowledges that ODA responsible for implementing the Agricultural Water Quality Program. ODA implements the Agricultural Water Quality Program by enacting area rules which designate minimum standards that must be met on all agricultural or rural lands, and an area plan to meet these standards (ODA, 2017).

As required by the TMDL, DMAs are responsible for adopting a TMDL Implementation Plan to address required load reductions and an annual progress report. As previously mentioned in this document, ODA is not formally required to develop a TMDL implementation plan, however, they are required under the AgWQMA to construct an area plan which must address strategies to comply with a TMDL (if one is in place). Additionally, BMP implementation progress is assessed in biennial reports that are reviewed by both DEQ and a local advisory 
committee (LAC) made up of members appointed by ODA. The initial area plan for the Lower Willamette River was developed by ODA in partnership with local soil and water conservation districts (SWCD) and was adopted in 2003. The plan has been periodically revised to address modifications suggested by the LAC during each biennial review (2007, 2009, 2011, and 2015), and was most recently revised in 2017. Under OAR 603-090-0010, ODA has designated local SWCDs to help implement area plans. These agencies include East and West Multnomah SWCD, and Clackamas County SWCD.

The current Area plan designates sources of bacterial discharge within the agricultural regions of the Johnson Creek Watershed to include CAFOs for point sources and runoff from livestock and other agricultural operations for non-point sources. ODA is the lead agency for managing CAFOs. However, both ODA and DEQ jointly issue NPDES permits. CAFOs within Johnson Creek are currently not permitted to discharge any waste from areas of animal confinement with the exception of a storm event greater than the one-in-five-year, 24-hour duration storm from November 1 to May 21 or greater than the one-in-ten-year, 24-hour duration storm from May 22 through October 31 (ODEQ, 2006). Major non-point bacterial sources, including in-stream grazing by livestock and soil amendments (manure and fertilizer), are addressed in the Area Plan. 
ODA recommends landowners to take precautionary actions to mitigate stream impacts, such as off-stream watering of livestock and vegetative buffers to minimize run-off of manure. Although ODA emphasizes voluntary compliance of landowners, non-compliance will result in a Notice of Noncompliance and civil penalties if the offence is not addressed within a given timeline. A summary of BMPs implemented by ODA to reduce bacterial loading can be found in the table below (Table 24).

Table 24. Summary of major implementation activities for Lower Willamette conducted by ODA and local SWCDs reported in biennial reports for 2003-2006, 2007-2009, 2009-2011, 2013-2015, and 2015-2017

\begin{tabular}{|c|c|c|}
\hline $\begin{array}{c}\text { BEST } \\
\text { MANAGEMENT } \\
\text { PRACTICE (BMPs) }\end{array}$ & GOALS & STATUS \\
\hline $\begin{array}{l}\text { Education and } \\
\text { Outreach }\end{array}$ & NA & 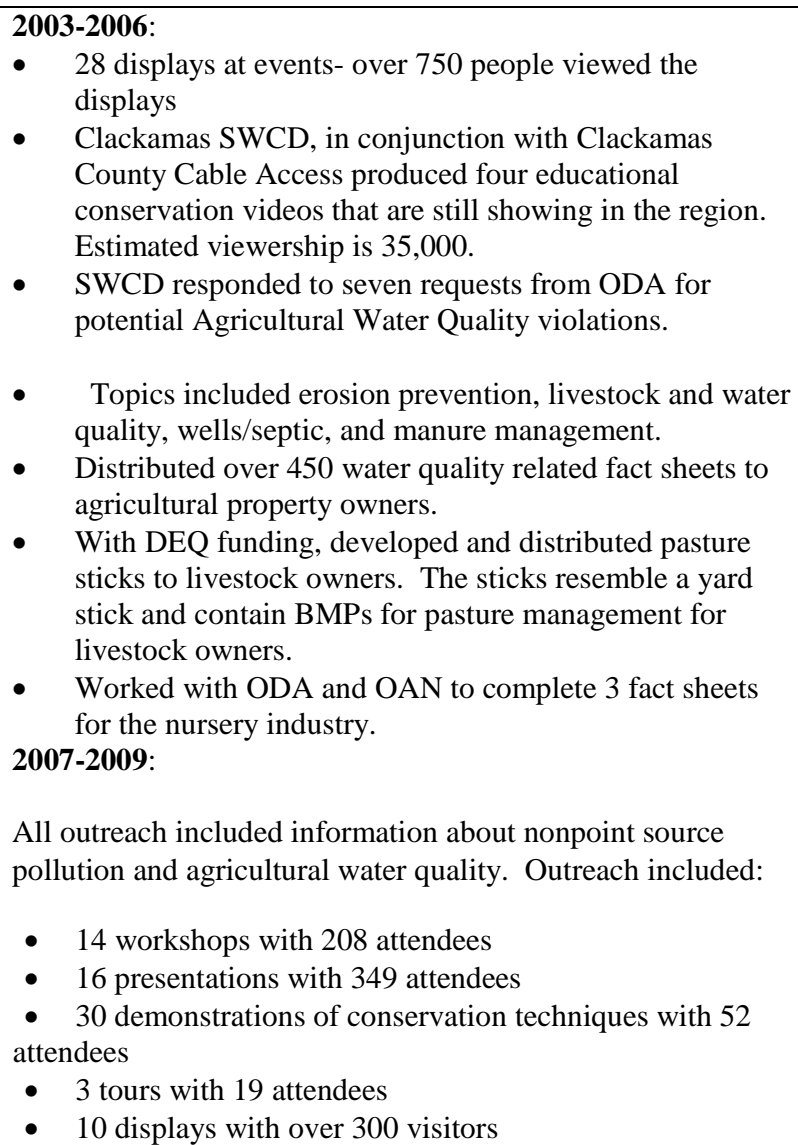 \\
\hline
\end{tabular}




\begin{tabular}{|c|c|}
\hline & $\begin{array}{l}\text { - } 5235 \text { fact sheets distributed } \\
\text { - launch of the EMSWCD website in } 2007 \\
\text { 2009-2011: } \\
\text { CCSWCD publications include 'Rural Lifestyles } \\
\text { Handbook and Pocket Guide' and the updated 'Tips on } \\
\text { Land \& Water Management for Small Acreages in } \\
\text { Oregon'. } \\
\text { 2011-2013: No report available for the following period } \\
\text { 2013-2015: } \\
\text { Developed 'Rural Living Handbook' for agricultural } \\
\text { producers in the Lower Willamette Management Area } \\
\text { Note: Reporting is very broad in this review and less } \\
\text { detailed than prior years. } \\
\text { 2015-2017: } \\
\text { Distributed } 1228 \text { newsletters } \\
\text { Note: Reporting is very broad in this review and less } \\
\text { detailed than prior years. }\end{array}$ \\
\hline $\begin{array}{l}\text { Prevent conditions } \\
\text { already prohibited } \\
\text { under ORS 468B.025 } \\
\text { and .050 } \\
\text { ( Provide Technical } \\
\text { Assistance) }\end{array}$ & 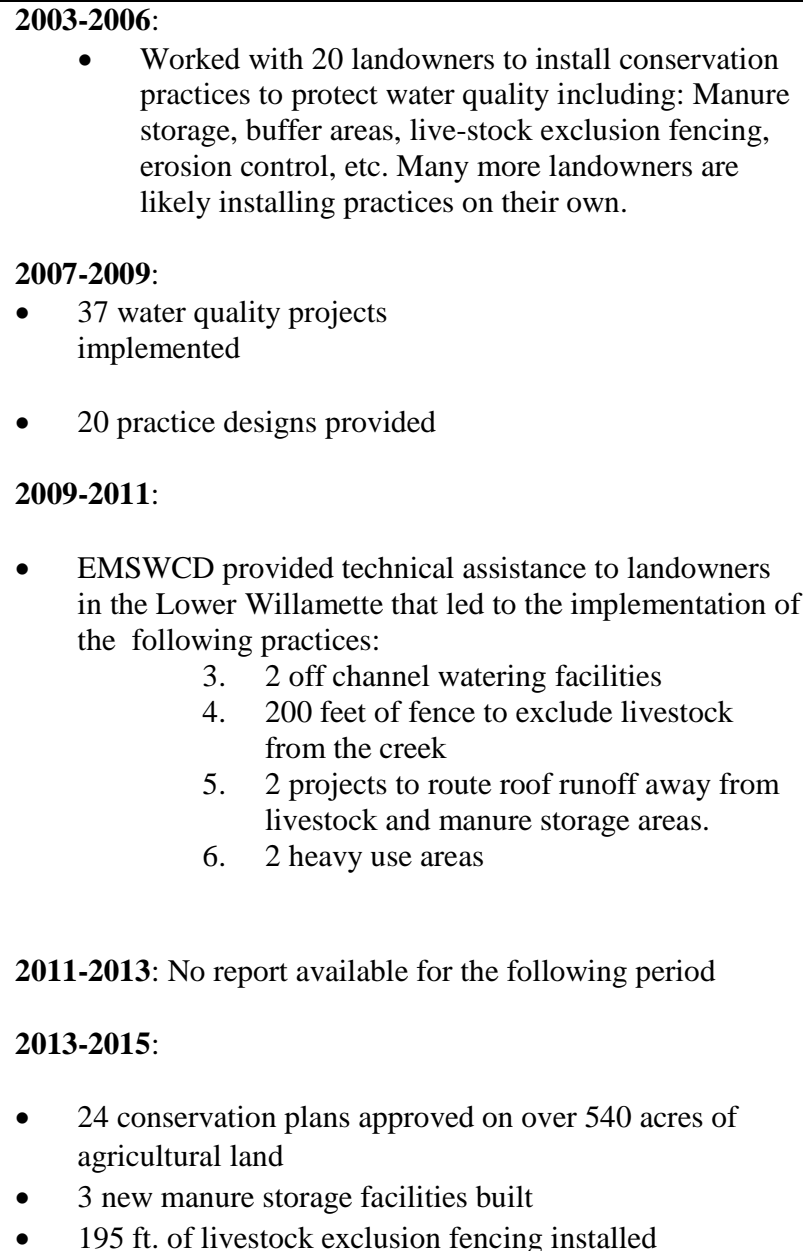 \\
\hline
\end{tabular}




\begin{tabular}{|c|c|c|}
\hline & & $\begin{array}{l}\text { - } 60 \text { site visits resulting in site preparation and riparian } \\
\text { planting along } 135 \text { acres of streams } \\
\text { - } 25 \text { water quality projects implemented } \\
\text { 2015-2017: } \\
\text { - Implemented } 5 \text { water quality projects (4.8 acres) } \\
\text { - Performed } 35 \text { on-site evaluations }\end{array}$ \\
\hline Grant Writing & NA & $\begin{array}{l}\text { 2007-2009: Completed } 4 \text { grant proposals to fund technical } \\
\text { assistance for agricultural lands } \\
\text { 2009-2011: None reported for the following period } \\
\text { 2011-2013: No report available for the following period } \\
\text { 2013-2015: } 1 \text { grant application submitted for landowner } \\
\text { project } \\
\text { 2015-2017: None reported for the following period }\end{array}$ \\
\hline Erosion Control & $\begin{array}{l}\text { Control erosion so that there is no } \\
\text { visible evidence of erosion resulting } \\
\text { from agricultural activities } \\
\text { contributing, or having the likelihood } \\
\text { to contribute, sediment to waters of the } \\
\text { state }\end{array}$ & 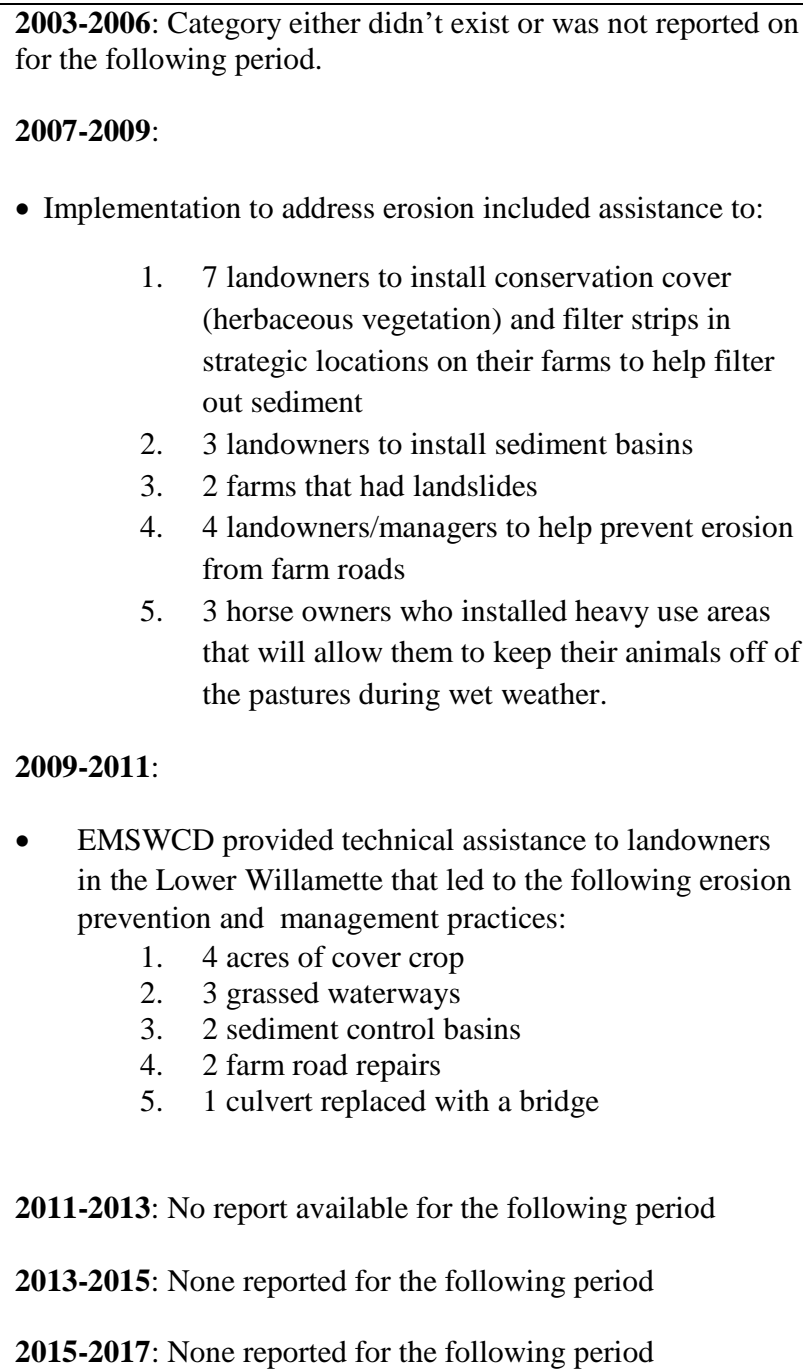 \\
\hline
\end{tabular}




\begin{tabular}{|c|c|c|}
\hline Natural Development & $\begin{array}{l}\text { Promote natural or managed } \\
\text { development of riparian vegetation } \\
\text { appropriate to site capability that } \\
\text { provides riparian function over time }\end{array}$ & $\begin{array}{l}\text { 2003-2006: Category either didn't exist or was not reported on } \\
\text { for the following period. } \\
\text { 2007-2009: } \\
\text { - The SWCDs partnered with landowners to plant } 7.5 \text { acres } \\
\text { of native trees and shrubs in riparian areas. This is } \\
\text { approximately } 8000 \text { plants. } \\
\text { Removed a dam from Kelley Creek to provide access to } \\
\text { an additional } 2500 \text { feet of high quality habitat in upper } \\
\text { reaches of the creek. } \\
\text { - } \\
\text { Enrolled individuals in StreamCare program to create a } \\
\text { 16 acre agricultural buffer area in Johnson Creek } \\
\text { 2011-2013: None reported for the following period } \\
\text { 2013-2015: None reported for the following period } \\
\text { 2015-2017: None reported for the following period }\end{array}$ \\
\hline $\begin{array}{l}\text { Control Manure } \\
\text { Runoff }\end{array}$ & $\begin{array}{l}\text { Control nutrients from manure pile } \\
\text { leachate, from overland runoff, and by } \\
\text { using appropriate fertilizer rates }\end{array}$ & $\begin{array}{l}\text { 2003-2006: Category either didn’t exist or was not reported on } \\
\text { for the following period. } \\
\text { 2007-2009: } \\
\text { - Six workshops with } 88 \text { attendees, including presentations } \\
\text { about proper manure storage, grazing to minimize runoff, } \\
\text { composting, off-channel watering, and manure } \\
\text { utilization. } \\
\text { Presented an annual workshop, which teaches people } \\
\text { about the water quality implications of septic system } \\
\text { maintenance. } \\
\text { Introduced 'Manure Connection' to our web page, which } \\
\text { allows landowners that have excess manure an } \\
\text { opportunity to make connections with gardeners looking } \\
\text { for an organic soil amendment. } \\
\text { Technical assistance provided to landowners: } \\
\text { 1. } 8 \text { landowners installed gutters and downspouts } \\
\text { to direct clean roof water away from animal } \\
\text { areas and manure piles } \\
2 \text { landowners received cost share and installed } \\
\text { manure storage sheds } \\
\text { 3. landowners installed fencing along } 1000 \text { feet } \\
\text { of riparian area to restrict livestock access to } \\
\text { surface water }\end{array}$ \\
\hline & & $\begin{array}{l}\text { 2009-2011: NA } \\
\text { 2011-2013: None reported for the following period } \\
\text { 2013-2015: None reported for the following period } \\
\text { 2015-2017: None reported for the following period }\end{array}$ \\
\hline
\end{tabular}




\section{Results}

\section{Descriptive Statistics}

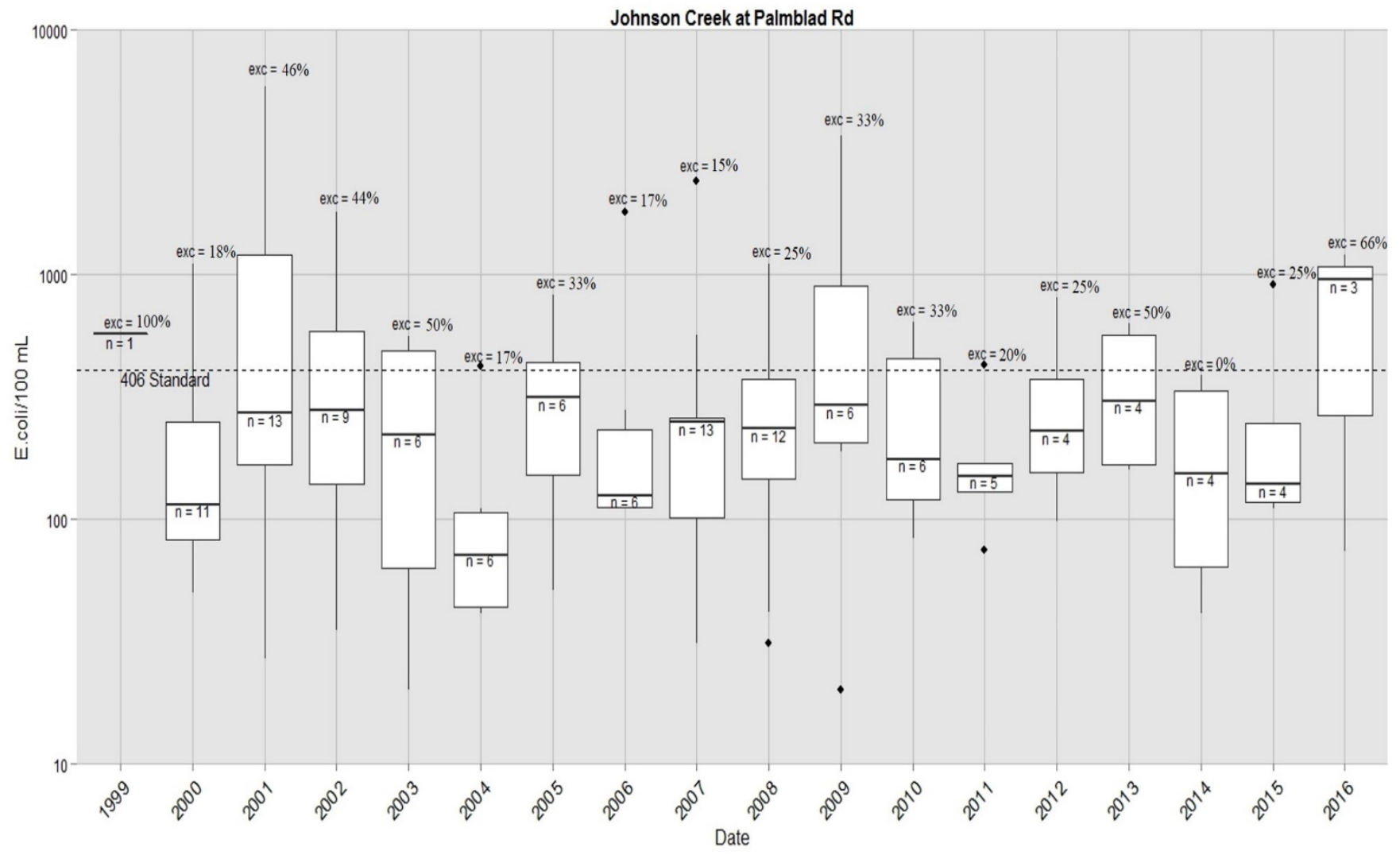

Figure 8. Boxplot displaying E. coli 406 cfu/100 mL standard exceedances overtime for Palmblad Rd. 


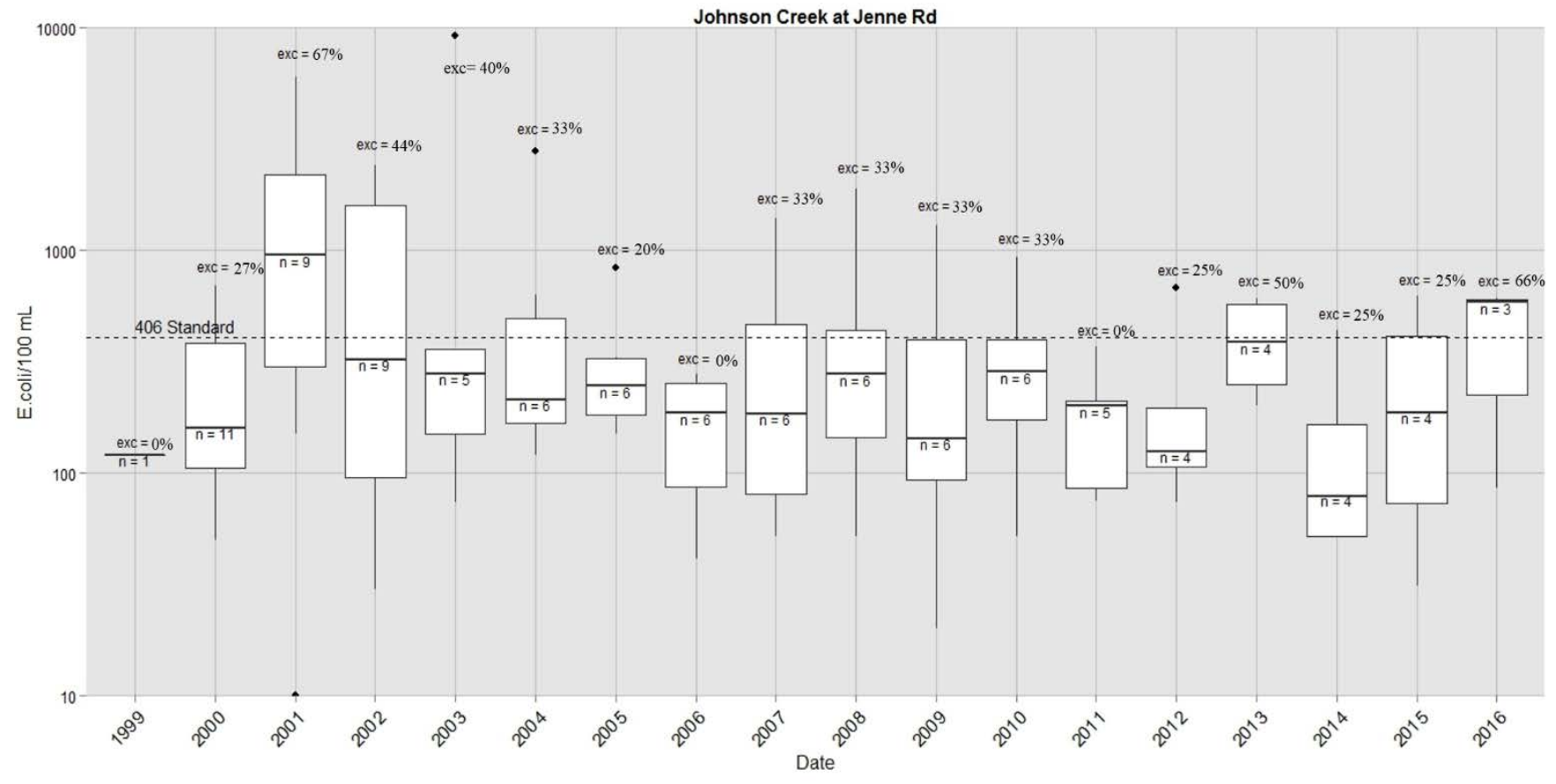

Figure 9. Boxplot displaying E. coli $406 \mathrm{cfu} / 100 \mathrm{~mL}$ standard exceedances overtime for Jenne Rd. One outlier in 2003 is not shown in graph, concentration was approximately $24,000 \mathrm{cfu}$.

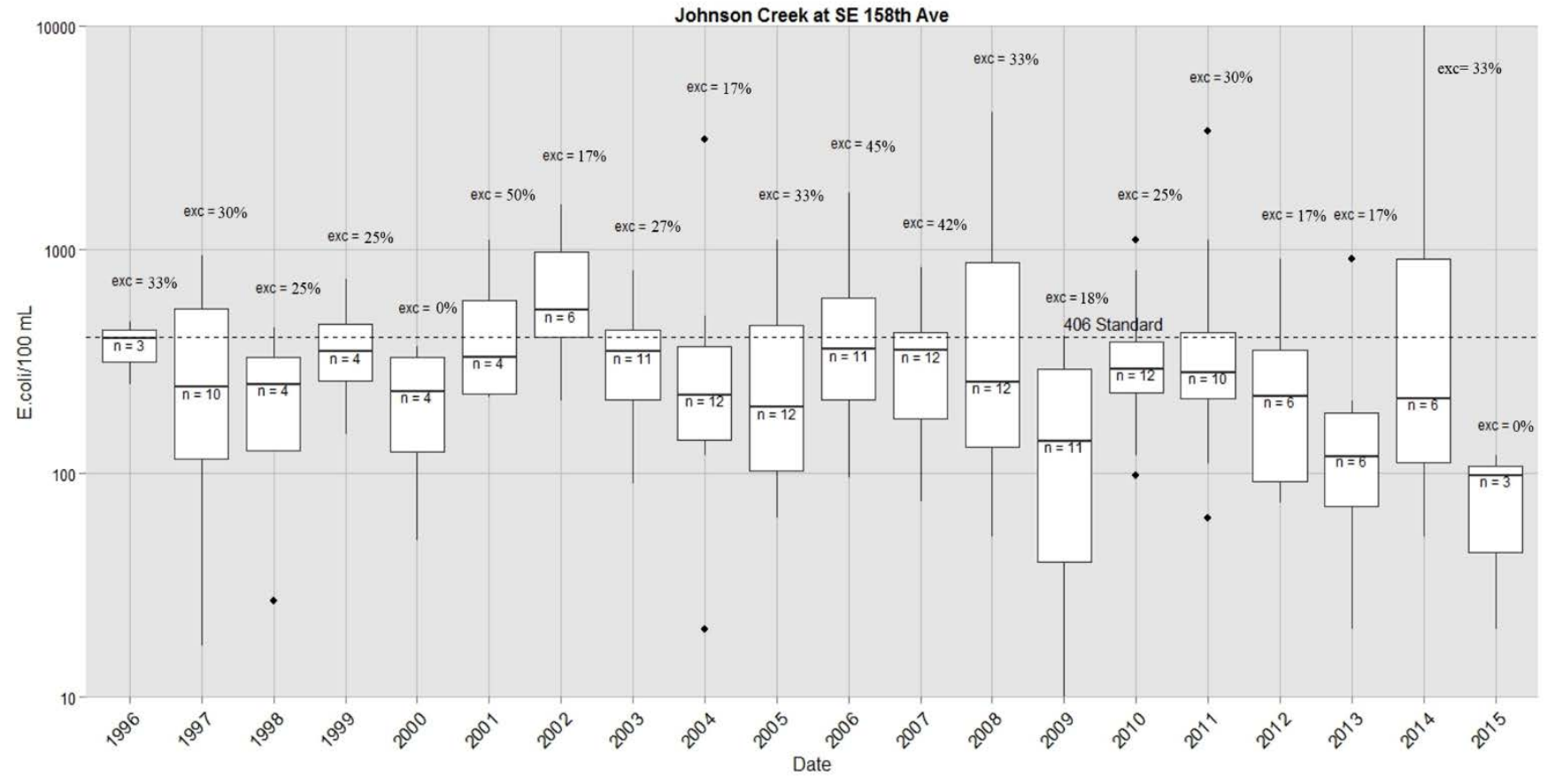

Figure 10. Boxplot displaying E. coli $406 \mathrm{cfu} / 100 \mathrm{~mL}$ standard exceedances overtime for SE $158^{\text {th }}$ Ave. One outlier in 2009 is not shown in graph, concentration was approximately 20,000 cfu. 


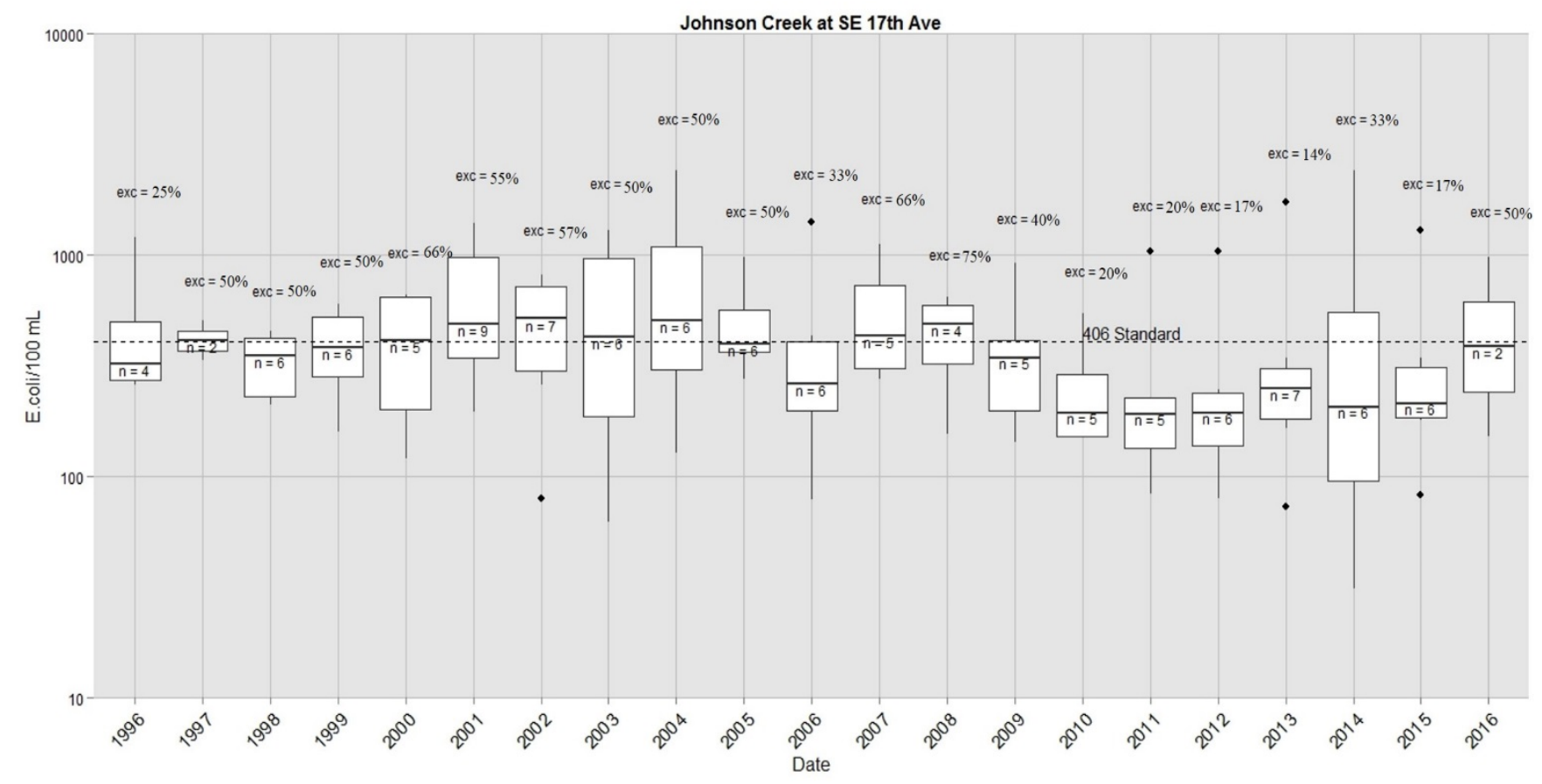

Figure 11. Boxplot displaying E. coli $406 \mathrm{cfu} / 100 \mathrm{~mL}$ standard exceedances overtime for SE $17^{\text {th }}$ Ave.

\section{Results}

With the exception of SE $17^{\text {th }}$ Ave, visual inspection of Figure 8-Figure 11 showed no apparent monotonic trends with regards to both the median concentration of $E$. coli and the percent exceedances per year of the 406 single sample standard. Palmblad Ave which is near where Johnson Creek enters the City of Gresham in the rural/agricultural portion of the upper watershed, displayed an alternating decreasing-increasing trend over time (1999-2016) for both percent exceedances of the $406 \mathrm{cfu} / 100 \mathrm{~mL}$ standard and for median E. coli concentrations (Figure 8) . The $406 \mathrm{cfu} / 100 \mathrm{~mL}$ standard was exceeded at least once in Palmblad Ave for every year but 2014 (Figure 8). The highest E. coli concentration for Palmblad Ave was collected in 2001 and was approximately 6,000 colony forming units (cfu), the second highest E. coli concentration was collected in 2009 and was approximately 4,000 cfu, and the highest concentration for the most recent samping year (2016) was approximately 1,200 cfu (Figure 8). 
Despite these findings, comparison of water quality between years was difficult as sampling frequency was not consistent. Following 2002, samples were collected on an approximately bimonthly basis (no consistent pattern before), and following 2011, samples were collected every three months.

The next site Jenne Rd, which is located downstream of Palmblad Ave in City of Gresham, showed no apparent visual trend over time (1999-2016) with regards to both percent exceedances of the $406 \mathrm{cfu} / 100 \mathrm{~mL}$ standard and median concentrations of $E$. coli (Figure 9). Samples collected at Jenne Rd. exceeded the $406 \mathrm{cfu} / 100 \mathrm{~mL}$ standard at least once for all years but 1999, 2006, and 2011 (Figure 9). The highest E. coli concentrations for Jenne Rd. were collected in 2003 (both outliers) and were aproximately 9,200 and 24,000 cfu (Figure 9), 2001 had the next highest E. coli concentration at approximately 2,900 colony forming units (cfu) (Figure 9), and the highest concentration for the most recent sampling year (2016) was approximately 610 cfu (Figure 9) . Sampling frequency for Jenne Rd. was consistent with Palmblad Rd., following 2002 (no consistent pattern before) samples were collected on an approximately bimonthly basis, and following 2011 samples were collected once every three months.

SE $158^{\text {th }}$ the next study site, is located downstream of Jenne Rd near the Sycamore Rd flow gauge at the entrance of the City of Portland watershed boundary. SE $158^{\text {th }}$ showed no apparent visual trend over time (1996-2015) with regards to both percent exceedances of the 406 cfu/100 mL standard and median concentrations of E. coli (Figure 10). Samples collected at SE $158^{\text {th }}$ Ave exceeded the $406 \mathrm{cfu} / 100 \mathrm{~mL}$ standard at least once for all years but 2000 and 2015 (Figure 10) . The highest E. coli concentration for SE $158^{\text {th }}$ Ave (outlier) was collected in 2009 and was aproximately 20,000 cfu (Figure 10), 2014 had the next highest E. coli concentration at 
approximately 10,000 colony forming units (cfu) (Figure 10), and the highest concentration for the most recent sampling year (2016) was approximately $120 \mathrm{cfu}$ (Figure 10). Sampling frequency for SE $158^{\text {th }}$ was inconsistent between years. Samples were collected on a monthly basis from 19961999, were collected once per month for dry months only (July- Oct) from 2000-2002, were collected on an approximately monthly basis from 2002-2011 and were collected on an approximately bimonthly basis from 2012-2015.

The last study site, SE $17^{\text {th }}$ Ave , is surrounded by industrial land in the City of Milwaukie near the mouth of the creek and recieves inputs from the entire watershed. Visual inspection of SE $17^{\text {th }}$ Ave revealed a decline in both percent exceedances of the $406 \mathrm{cfu} / 100 \mathrm{~mL}$ standard and median E. coli concentrations following 2009 (with the exception of 2014 and 2016) (Figure 11). SE $17^{\text {th }}$ exceeded the $406 \mathrm{cfu} / 100 \mathrm{~mL}$ standard at least once for all years from 1996-2016. Samples with the highest E. coli concentrations were collected in 2004 and 2014 and were approximatly 2,419 cfu, and 2,420 cfu respectively (Figure 11). The highest concentration of E. coli collected during the most recent sampling year (2016) was approximately $980 \mathrm{cfu}$. Sampling frequency at SE $17^{\text {th }}$ Ave was inconsistent between years. Samples were collected once every three months in 1996, once in January and April in 1997, and on an approximately bimonthly basis from 1998-2016. 


\section{Trend Analysis}

E. coli

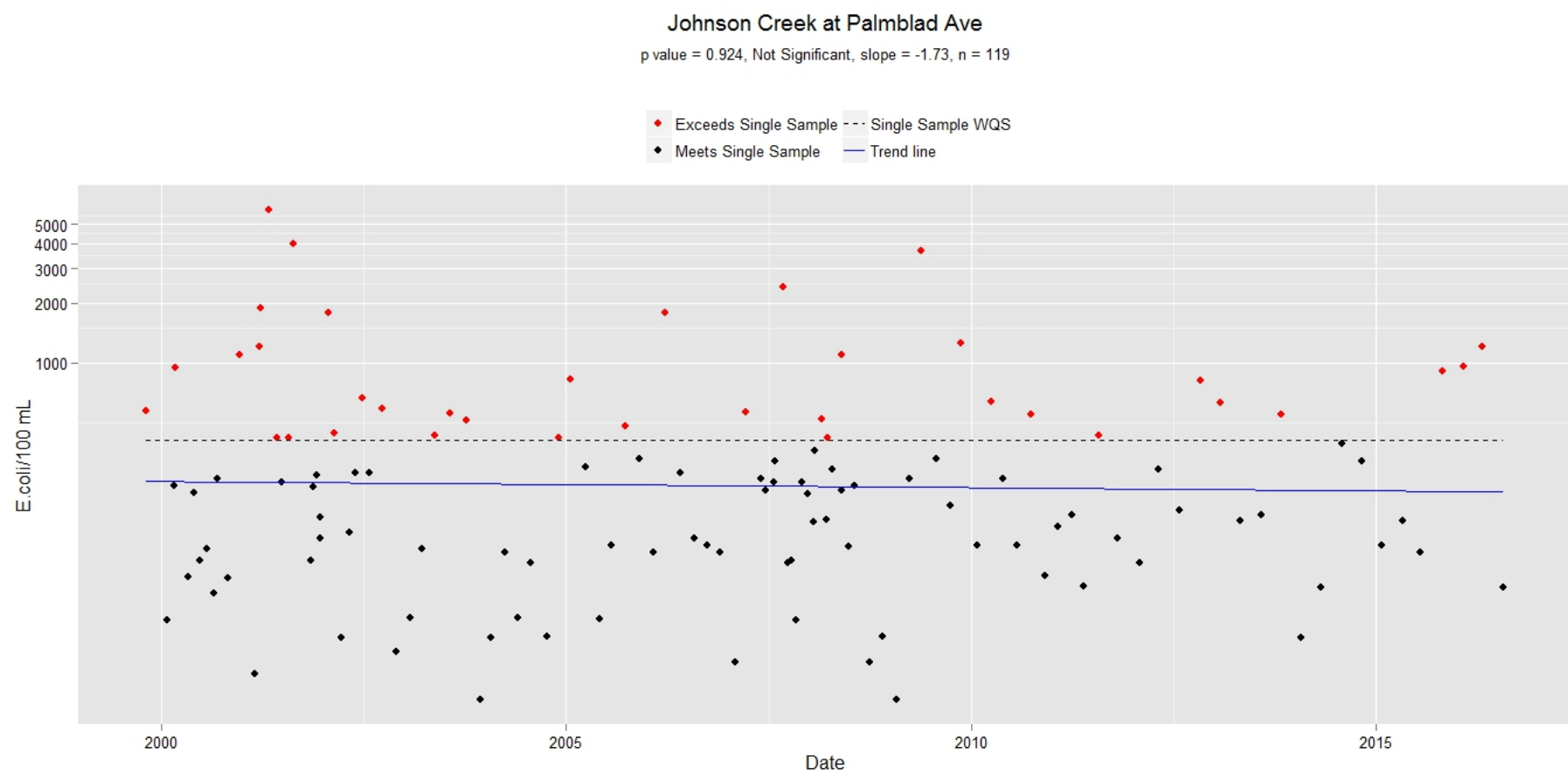

Figure 12. Seasonal Kendall trend analysis of E. coli time series data from 1999-2016 for Palmblad Rd. Blue line represents the median fitted line, red dots represent data that exceed the 406 single sample standard, black dots meet the 406 single sample standard, and the dashed line represents the 406 single sample standard. 


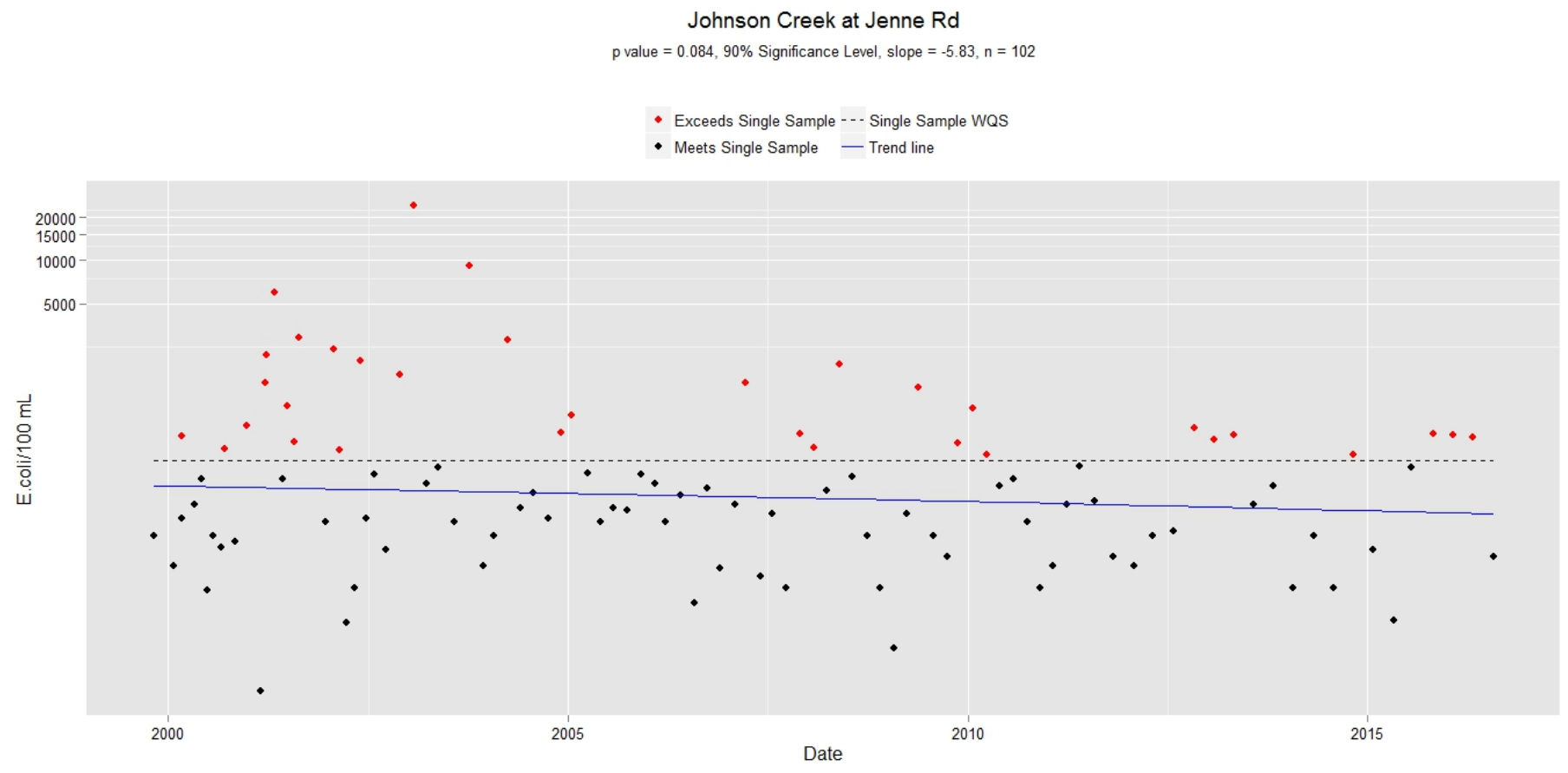

Figure 13. Seasonal Kendall trend analysis of E. coli time series data from 1999-2016 for Jenne Rd. Blue line represents the median fitted line, red dots represent data that exceed the 406 single sample standard, black dots meet the 406 single sample standard, and the dashed line represents the 406 single sample standard.

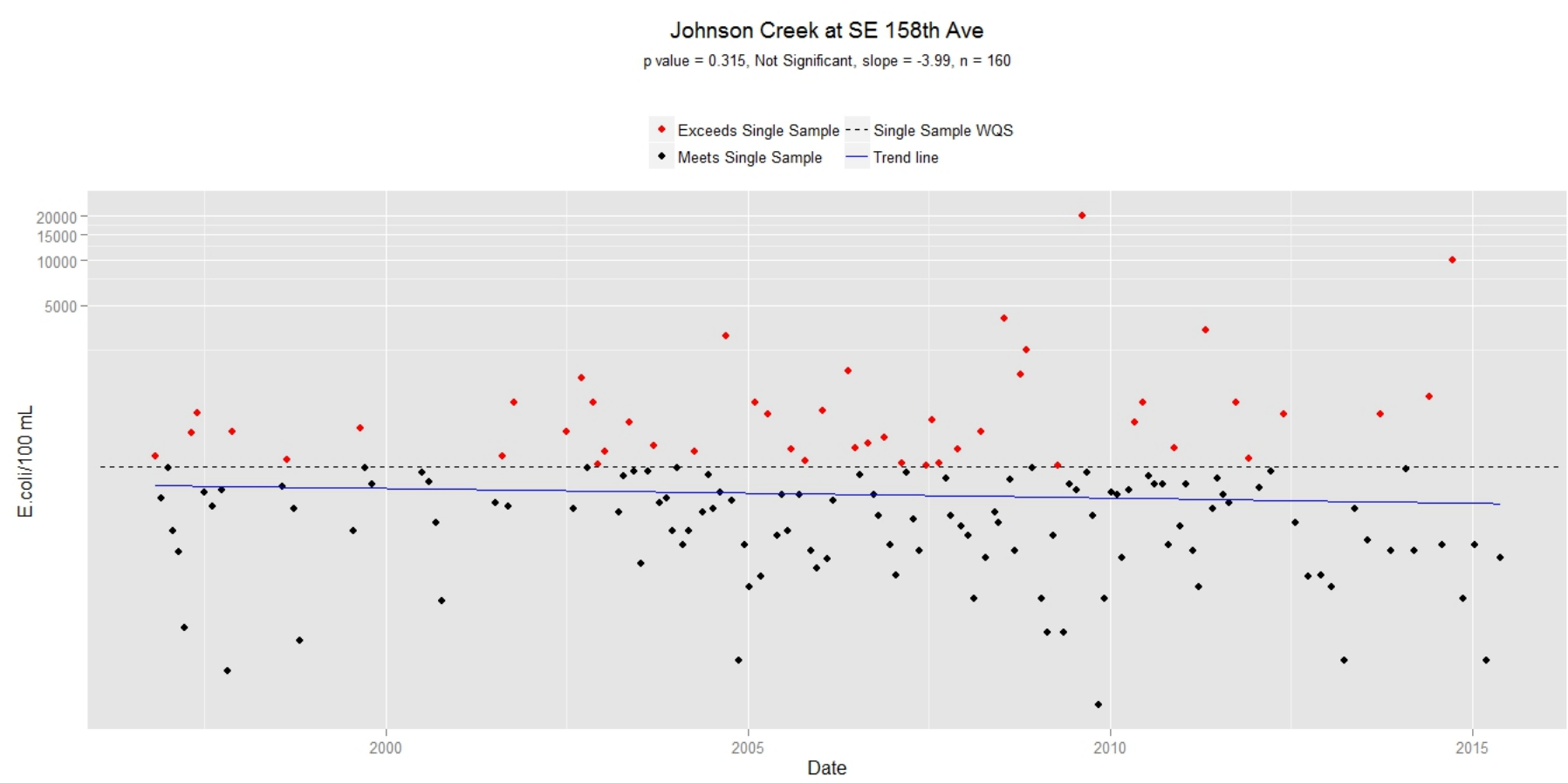

Figure 14. Seasonal Kendall trend analysis of E. coli time series data from 1996-2015 for SE $158^{\text {th }}$ Ave. Blue line represents the median fitted line, red dots represent data that exceed the 406 single sample standard, black dots meet the 406 single sample standard, and the dashed line represents the 406 single sample standard. 


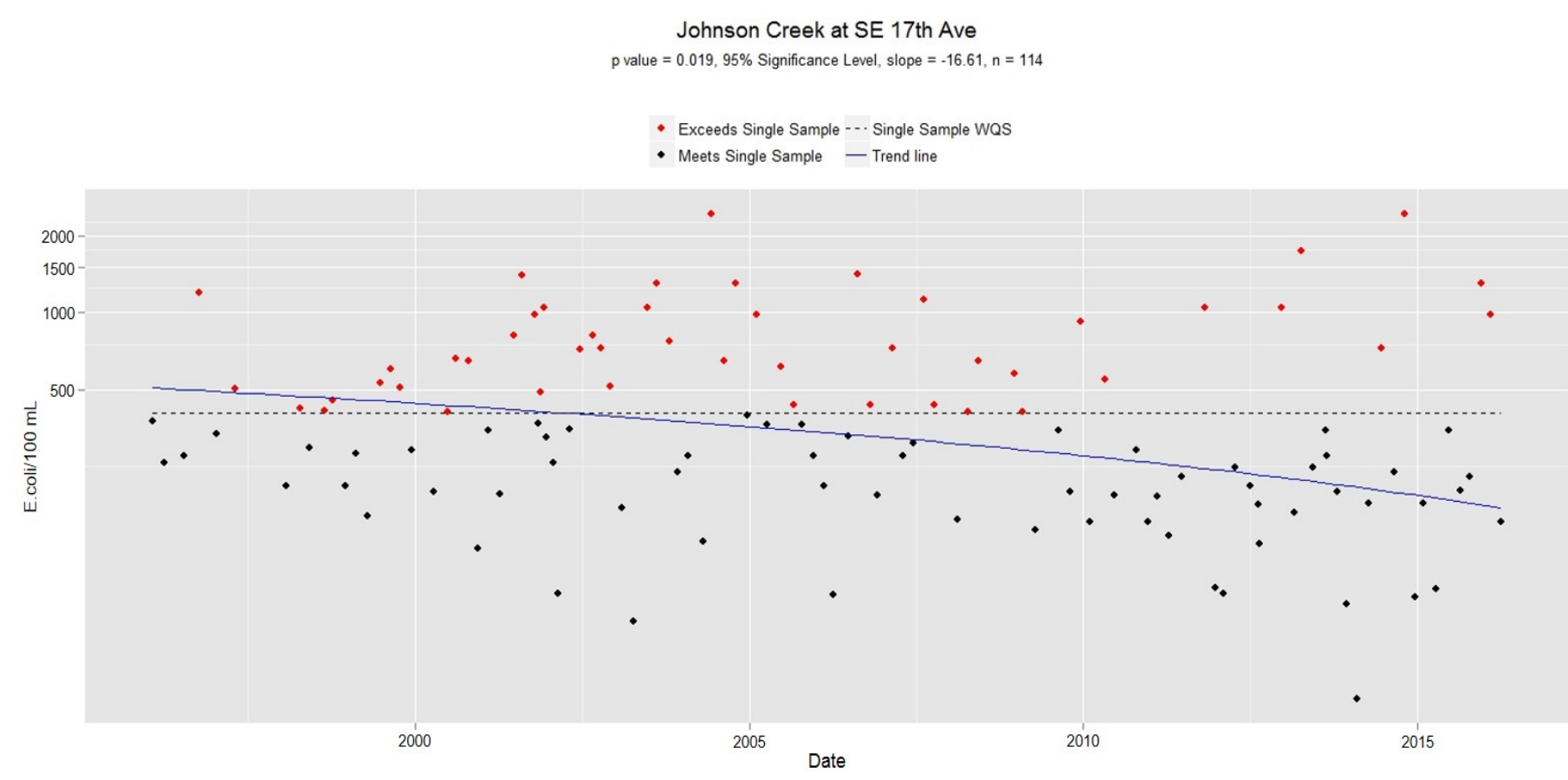

Figure 15. Seasonal Kendall trend analysis of E. coli time series data from 1996-2016 for SE $17^{\text {th }}$ Ave. Blue line represents the median fitted line, red dots represent data that exceed the 406 single sample standard, black dots meet the 406 single sample standard, and the dashed line represents the 406 single sample standard.

Results

A formal trend analysis was conducted for each four sampling sites to assess whether or not a monotonic upward or downward trend was present for concentrations of E. coli grab samples. Results from Seasonal Mann Kendall found that two out of the four study sites (Jenne Rd. and SE $17^{\text {th }}$ Ave) exhibited statisically significantly declining trends $(p<0.1)$ (Figure 13 and Figure 15). While SE $158^{\text {th }}$ Ave exhibited a slight but not statistically significant declining trend (Figure 14), and Palmblad Ave displayed a nearly horizontal trend line indicating no monotonic trend was present (Figure 12) . The median decrease in E. coli concentrations at Jenne Rd was approximately $99 \mathrm{cfu} / 100 \mathrm{~mL}$ from 1999-2016 (Slope= -5.83 cfu/100 mL/ Yr), while the median decrease for SE $17^{\text {th }}$ Ave was $332 \mathrm{cfu} / 100 \mathrm{~mL}$ from 1996-2016 (Slope= -16.61 cfu/100 mL/ Yr), (Figure 13 and Figure 15). 
Streamflow

Results

Trends in streamflow for water years (Oct 1-Sept 30) 1996-2016 were assessed with the Mann Kendall trend test for $0^{\text {th }}$ percentile, $10^{\text {th }}$ percentile, $30^{\text {th }}$ percentile, $70^{\text {th }}$ percentile, $90^{\text {th }}$ percentile, and $100^{\text {th }}$ percentile events for Palmblad Ave, Sycamore gauge, and Millport Rd gauge. Results of the Mann Kendall trend test revealed no statistically significant differences in streamflow between years for any of the percentile events, for any of the sites evaluated. Therefore, the null hypothesis that there is no significant differences between percentile flow events over the study period (water years 1996-2016) was upheld. Because E.coli loading is a function of both E.coli concentrations and streamflow, this finding indicates that both loading and E.coli concentration trends should not have any significant differences. Figures and tables supporting these findings can be found in the appendix of this document (Figure 36-Figure 44) and (Table 47-Table 49). 


\section{Precipitation}
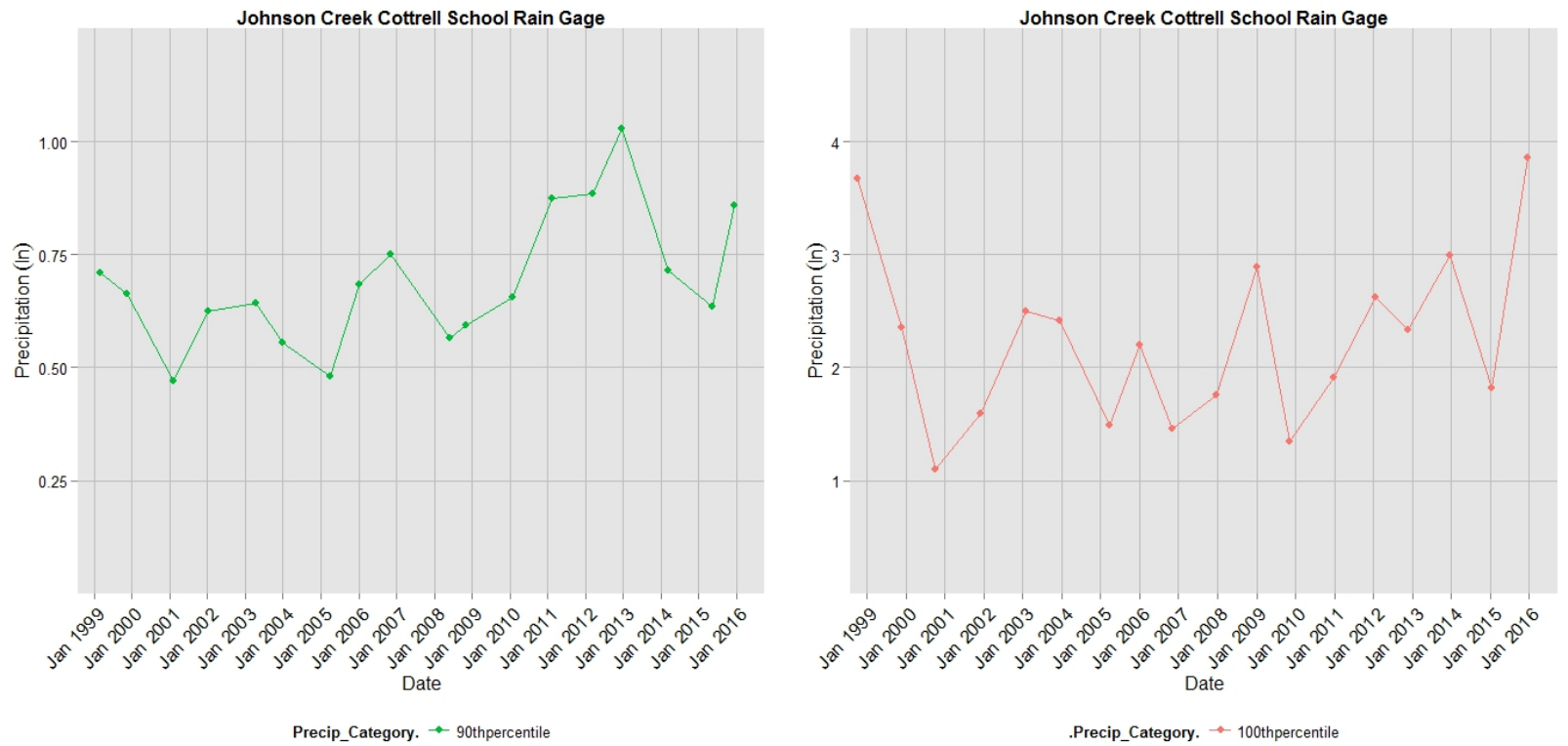

Figure 16. Time series plot of $90^{\text {th }}$ and $100^{\text {th }}$ percentile precipitation events at Cottrell School rain gauge for water years (Oct 1- Sept 30) 1996-2016.

Table 25. Mann Kendall results for time series data for $90^{\text {th }}$ and $100^{\text {th }}$ percentile precipitation events at Cottrell School rain gauge for water years (Oct 1- Sept 30) 1996-2016.

\begin{tabular}{|c|c|c|c|c|c|}
\hline Station & $\begin{array}{l}\text { Water Years } \\
\text { (Oct-Sept) }\end{array}$ & $\begin{array}{l}\text { Precip Range } \\
\text { (Inches) }\end{array}$ & Kendall Tau & $\begin{array}{l}\text { Two-Side } p \text { - } \\
\text { value }\end{array}$ & $\begin{array}{l}\text { Trend Slope } \\
\text { (Inches/Year) }\end{array}$ \\
\hline \multirow{4}{*}{$\begin{array}{l}\text { Cottrell } \\
\text { School Rain } \\
\text { Gauge }\end{array}$} & \multicolumn{5}{|c|}{ Annual $90^{\text {th }}$ percentile daily precipitation $\left(Q_{90}\right)$} \\
\hline & $1999-2016$ & $0.47-1.03$ & 0.346 & $0.04 * *$ & 0.015 \\
\hline & \multicolumn{5}{|c|}{ Annual maximum daily precipitation $\left(\mathrm{Q}_{100}\right)$} \\
\hline & 1999-2016 & 1.1-3.9 & 0.15 & 0.41 & 0.033 \\
\hline
\end{tabular}

Note:

$90 \%$ significance level $=*$ $95 \%$ significance level $=* *$ $99 \%$ significance level $=* * *$ 

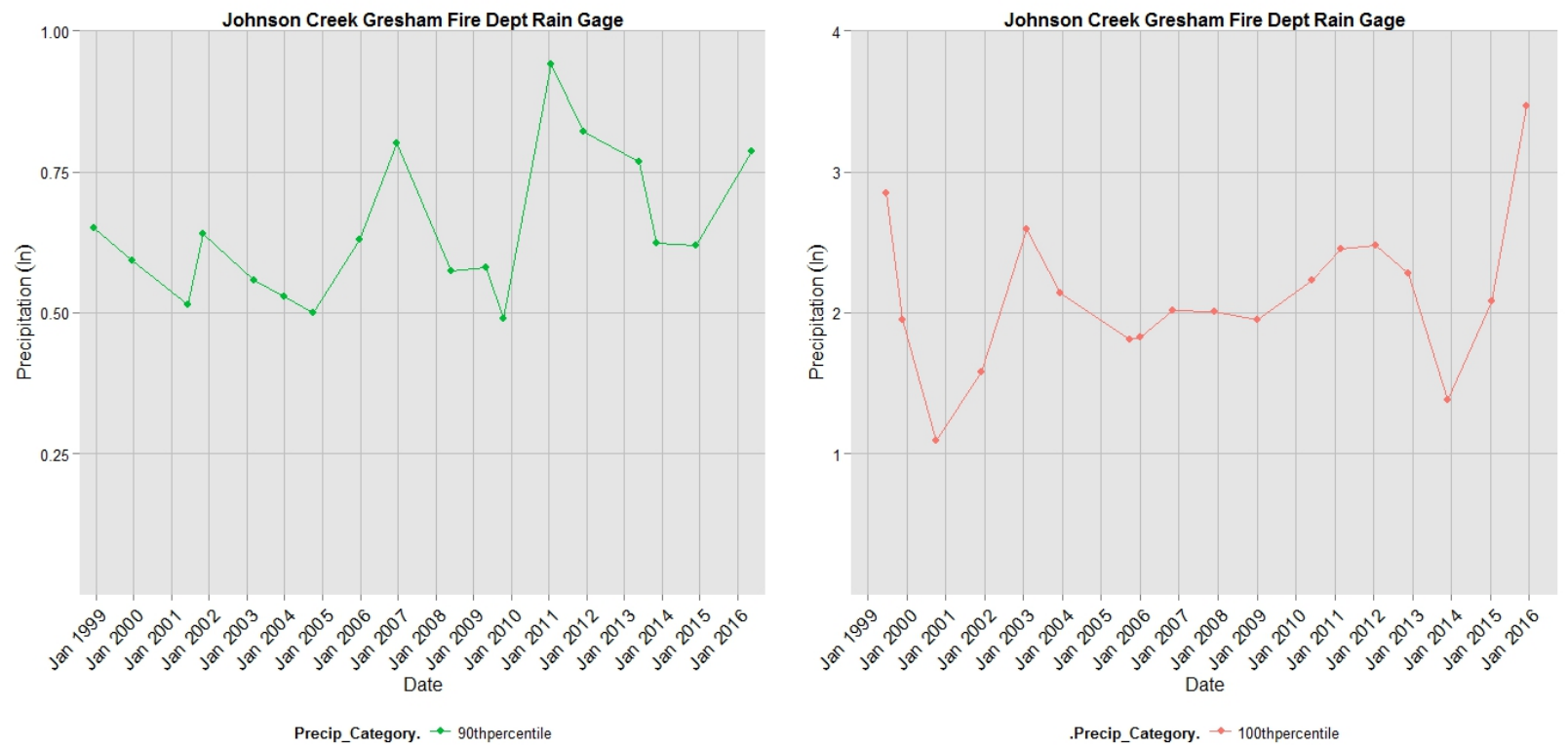

Figure 17. Time series plot of $90^{\text {th }}$ and $100^{\text {th }}$ percentile precipitation events at Gresham Fire Dept. rain gauge for water years (Oct 1- Sept 30) 1996-2016.

Table 26. Mann Kendall results for time series data for $90^{\text {th }}$ and $100^{\text {th }}$ percentile precipitation events at Gresham Fire Dept. rain gauge for water years (Oct 1- Sept 30) 1996-2016.

\begin{tabular}{|c|c|c|c|c|c|}
\hline Station & $\begin{array}{l}\text { Water Years } \\
\text { (Oct-Sept) }\end{array}$ & $\begin{array}{l}\text { Precip Range } \\
\text { (Inches) }\end{array}$ & Kendall Tau & $\begin{array}{l}\text { Two-Side p- } \\
\text { value }\end{array}$ & $\begin{array}{l}\text { Trend Slope } \\
\text { (Inches/Year) }\end{array}$ \\
\hline \multirow{4}{*}{$\begin{array}{l}\text { Gresham Fire } \\
\text { Dept. Rain } \\
\text { Gauge }\end{array}$} & \multicolumn{5}{|c|}{ Annual $90^{\text {th }}$ percentile daily precipitation $\left(Q_{90}\right)$} \\
\hline & $1999-2016$ & $0.5-0.94$ & 0.19 & 0.29 & 0.008 \\
\hline & \multicolumn{5}{|c|}{ Annual maximum daily precipitation $\left(\mathrm{Q}_{100}\right)$} \\
\hline & 1999-2016 & $1.1-3.5$ & 0.223 & 0.21 & 0.035 \\
\hline
\end{tabular}

Note:

$90 \%$ significance level $=*$

$95 \%$ significance level $=* *$

$99 \%$ significance level $=* * *$ 

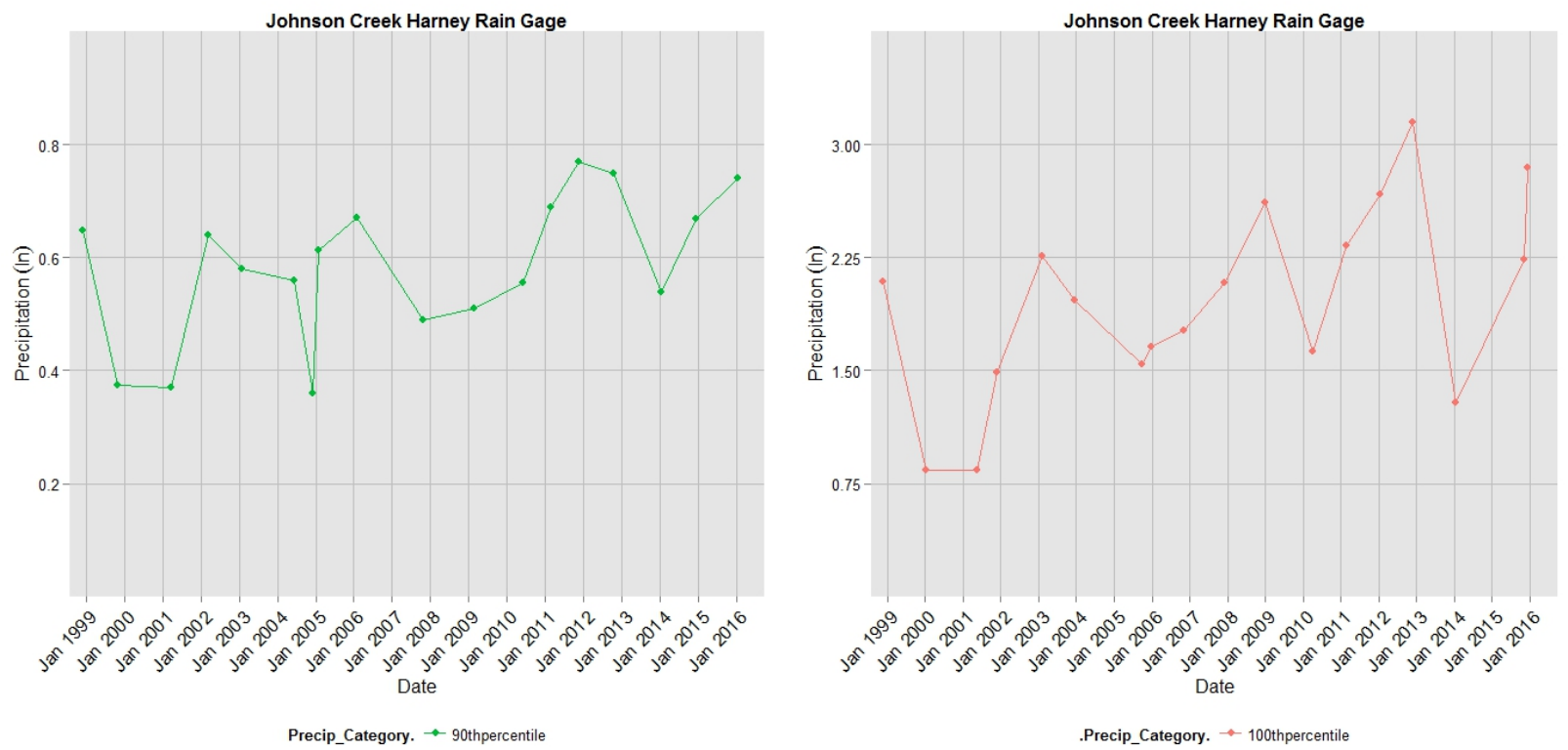

Figure 18. Time series plot of $90^{\text {th }}$ and $100^{\text {th }}$ percentile precipitation events at Harney rain gauge for water years (Oct 1Sept 30) 1996-2016.

Table 27. Mann Kendall results for time series data for $90^{\text {th }}$ and $100^{\text {th }}$ percentile precipitation events at Harney rain gauge for water years (Oct 1- Sept 30) 1996-2016.

\begin{tabular}{|c|c|c|c|c|c|}
\hline Station & $\begin{array}{l}\text { Water Years } \\
\text { (Oct-Sept) }\end{array}$ & $\begin{array}{l}\text { Precip Range } \\
\text { (Inches) }\end{array}$ & Kendall Tau & $\begin{array}{l}\text { Two-Side p- } \\
\text { value }\end{array}$ & $\begin{array}{l}\text { Trend Slope } \\
\text { (Inches/Year) }\end{array}$ \\
\hline Harney Rain & \multicolumn{5}{|c|}{ Annual $90^{\text {th }}$ percentile daily precipitation $\left(Q_{90}\right)$} \\
\hline Gauge & 1999-2016 & $0.36-0.77$ & 0.32 & $0.06^{*}$ & 0.013 \\
\hline & \multicolumn{5}{|c|}{ Annual maximum daily precipitation $\left(\mathrm{Q}_{\mathbf{1 0 0}}\right)$} \\
\hline $\begin{array}{l}\text { (SE } 17^{\text {th }} \\
\text { Ave) }\end{array}$ & $1999-2016$ & $0.84-3.2$ & 0.433 & $0.01 * * *$ & 0.087 \\
\hline
\end{tabular}

Note:

$90 \%$ significance level $=*$

$95 \%$ significance level $=* *$

$99 \%$ significance level $=* * *$ 
Results

Trends in precipitation for water years (Oct 1-Sept 30) 1999-2016 were assessed with the Mann Kendall trend test for $90^{\text {th }}$ percentile, and $100^{\text {th }}$ percentile events for Cottrell School rain gauge, Gresham Fire Dept. rain gauge, and Harney rain gauge (Figure 4). Statistically significant $(\mathrm{p}<0.05)$ increasing trends were found for both Cottrell School rain gauge (headwaters) (Table 25) and Harney rain gauge (near mouth of the watershed) (Table 27), but not for the Gresham Fire Dept. rain gauge (used to represent the middle of the watershed) (Table 26).

$90^{\text {th }}$ percentile precipitation events at the Cottrell School rain gauge had a statistically significant $(\mathrm{p}<0.05)$ differences between years (Figure 16) and (Table 25). 100 ${ }^{\text {th }}$ percentile precipitation events at the Cottrell School rain gauge by contrast were not significantly difference for water years 1999-2016 (Table 25). $90^{\text {th }}$ percentile precipitation events for Cottrell School rain gauge were found to be increasing by approximately 0.015 inches/year on average (median) for water years 1999-2016 (Table 25). The lowest $90^{\text {th }}$ percentile precipitation event (24 hour precipitation values) recorded by the Cottrell School rain gauge was 0.43 inches (2001)and the highest $90^{\text {th }}$ percentile precipitation event was 1.03 inches (2013) (Table 25). The use of Cottrell School rain gauge as a surrogate measure of precipitation for Palmblad Ave. in this study therefore, suggests that $90^{\text {th }}$ percentile precipitation events at Palmblad Ave. have been increasing from water years 1999-2016.

$90^{\text {th }}$ and $100^{\text {th }}$ percentile precipitation events recorded by the Gresham Fire Dept. rain gauge as previously mentioned, showed no significant trends for water years 1999-2016 (Table 26). Visual verification of these results showed $90^{\text {th }}$ percentile events to be fluctuating around an approximately constant mean (horizontal trend line), while $100^{\text {th }}$ percentile events were shown to have approximately equivalent peak events for the starting and ending period (water years 1999 
and 2016) (Figure 17). The use of Gresham Fire Dept. rain gauge as a surrogate measure of precipitation for both Jenne Rd and SE $158^{\text {th }}$ Ave. in this study therefore, suggests that no significant changes in $90^{\text {th }}$ and 100th percentile precipitation events have been occurring for either of these sites from water years 1999-2016.

Lastly, Harney rain gauge exhibited statistically significant $(\mathrm{p}<0.05)$ increasing trends for both $90^{\text {th }}$ and $100^{\text {th }}$ percentile precipitation events for water years $1999-2016$ (Table 27). $90^{\text {th }}$ and $100^{\text {th }}$ percentile precipitation events at Harney gauge were found to be increasing on average (median) by approximately 0.013 and 0.087 inches/year respectively (Table 27). The lowest $90^{\text {th }}$ percentile precipitation event (24 hour precipitation values) recorded by Harney rain gauge was 0.36 inches (2004) and the highest $90^{\text {th }}$ percentile precipitation event was 0.77 inches (2011) (Table 27). Further, the lowest $100^{\text {th }}$ percentile precipitation event (24 hour precipitation values) recorded by Harney rain gauge was 0.84 inches (2000 and 2001), and the highest $100^{\text {th }}$ percentile precipitation event was 3.2 inches (2013) (Table 27). The use of Harney rain gauge as a surrogate measure of precipitation for SE 17th Ave. in this study therefore, suggests that both $90^{\text {th }}$ and $100^{\text {th }}$ percentile precipitation events at SE $17^{\text {th }}$ Ave. have been increasing from water years 19992016. 


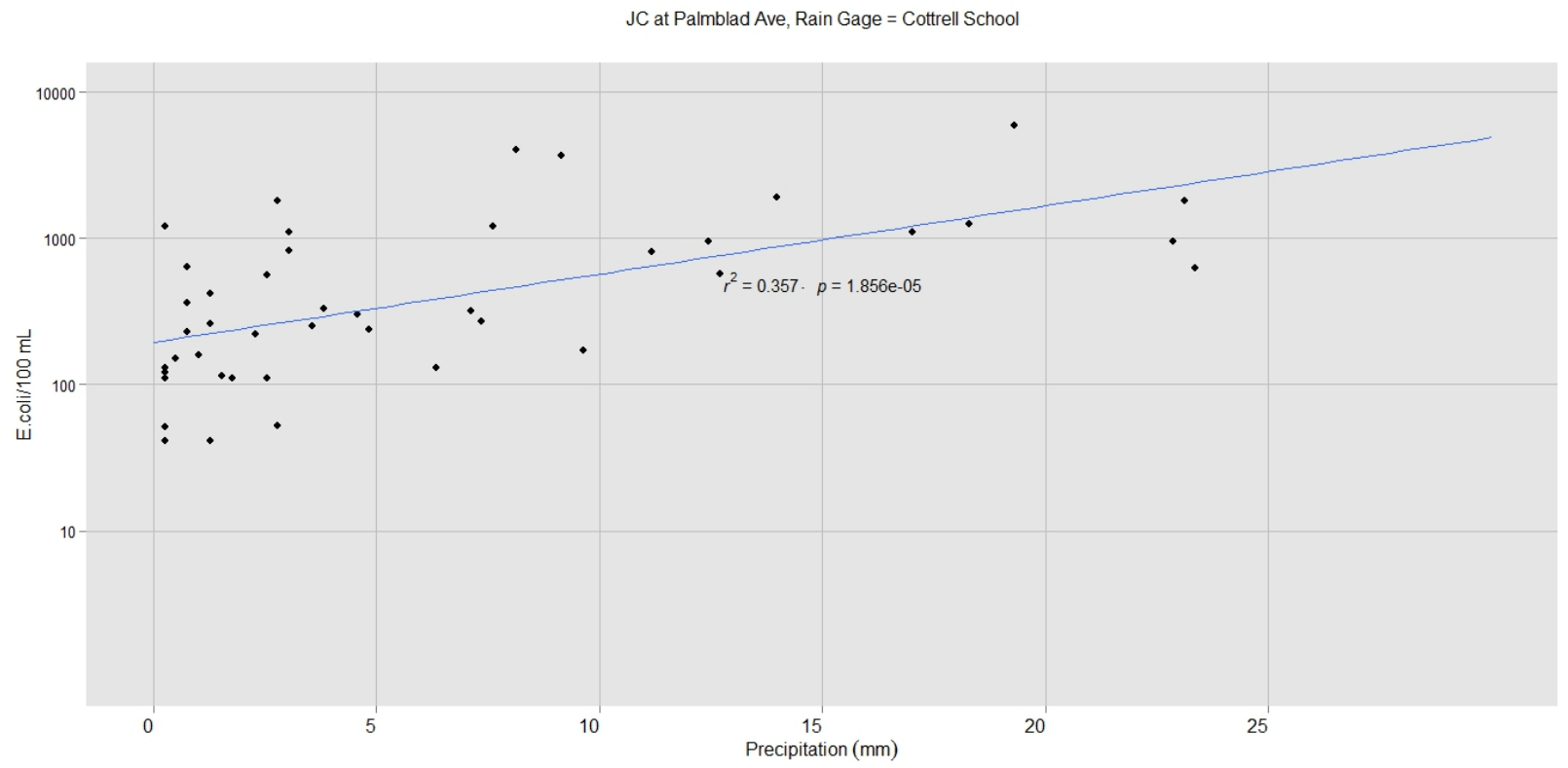

Figure 19. Fitted regression line for log base 10 transformed E. coli data from Palmblad Ave vs. cumulative precipitation from storm events prior to collection of grab samples for each sampling date.

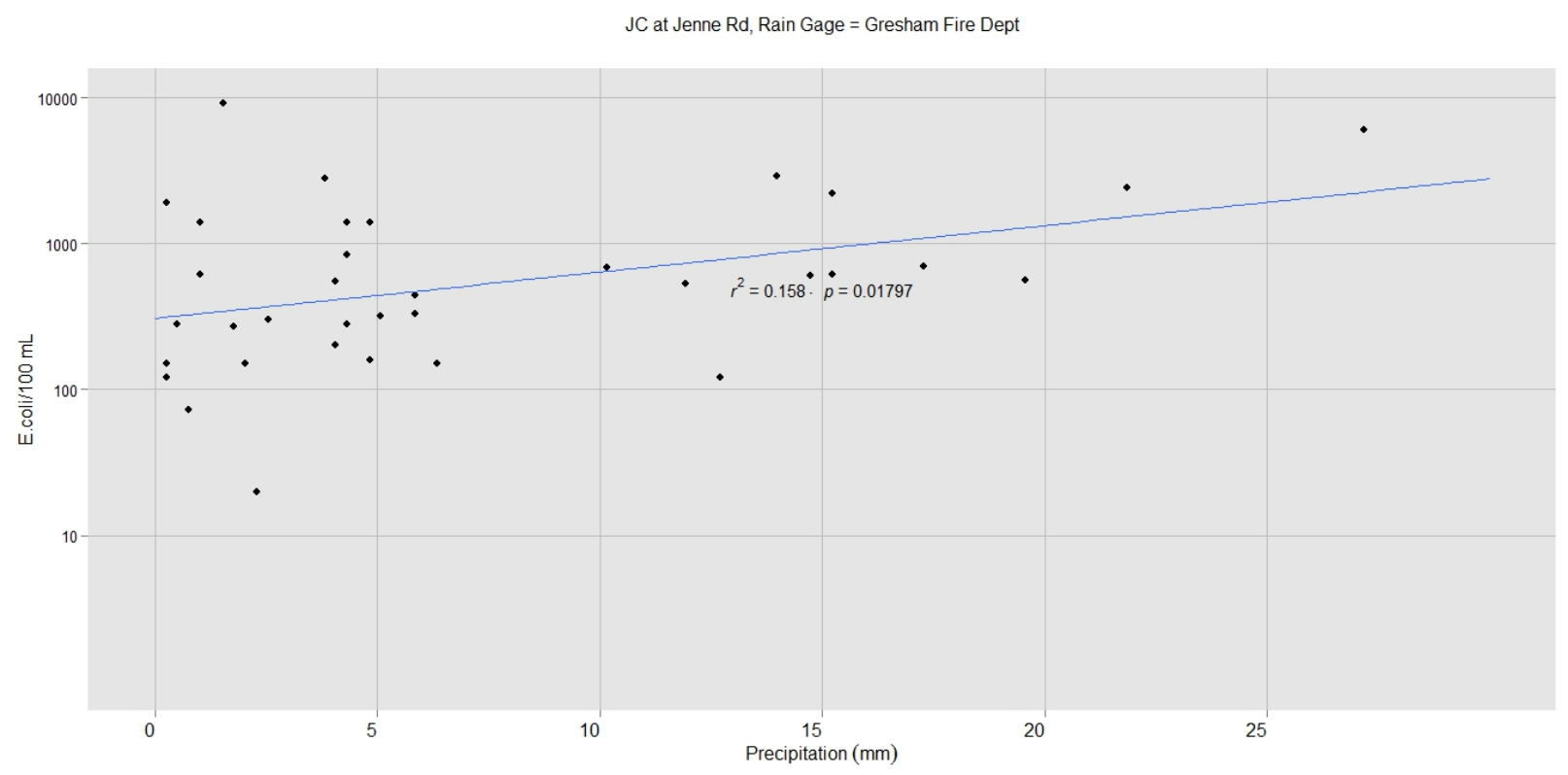

Figure 20. Fitted regression line for log base 10 transformed E. coli data from Jenne Rd. vs. cumulative precipitation from storm events prior to collection of grab samples for each sampling date. One outlier $(24,000 \mathrm{cfu} / 100 \mathrm{~mL}, 0 \mathrm{in}$ precip) exceeded the plot range and was removed. 


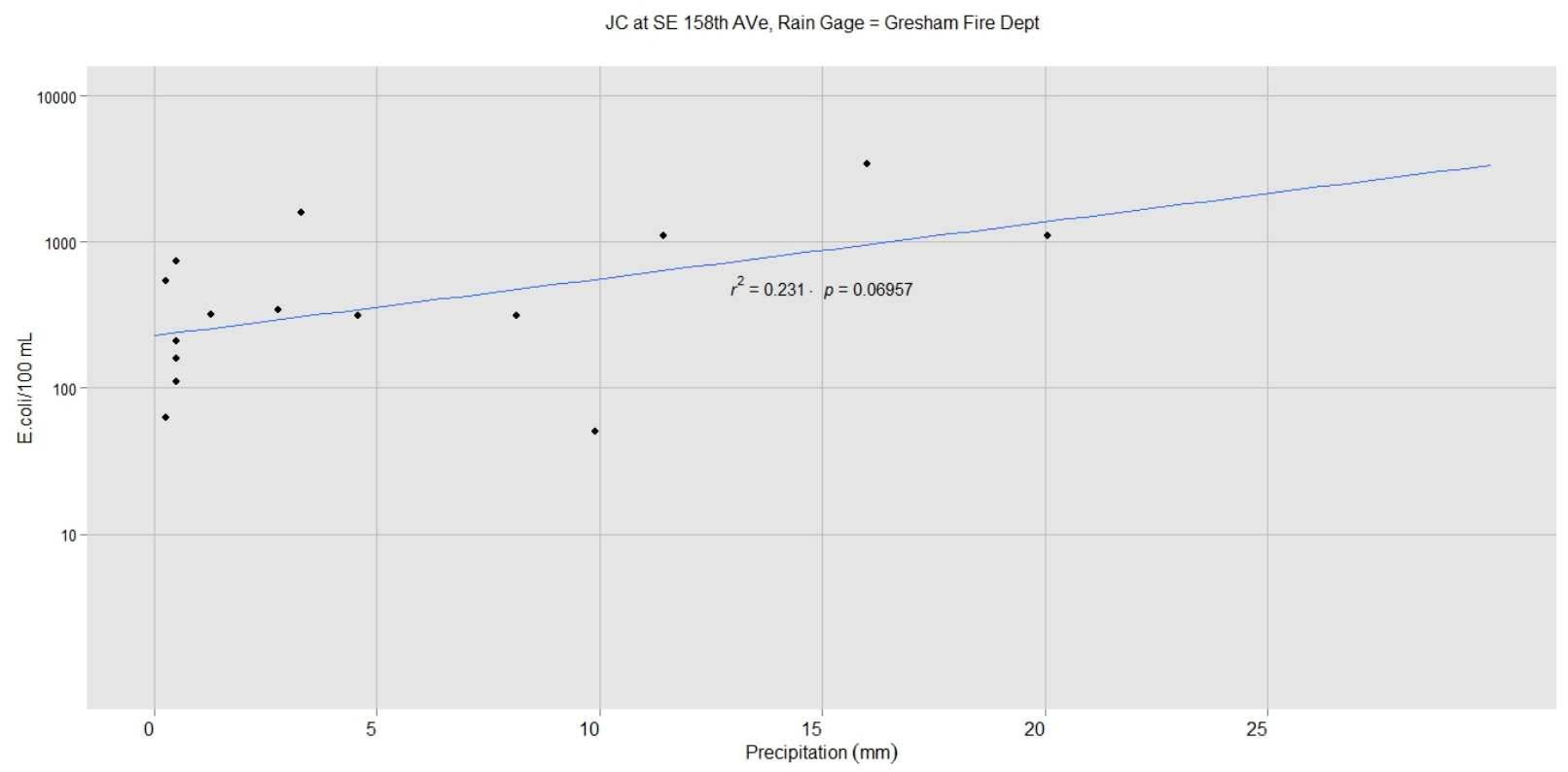

Figure 21. Fitted regression line for log base 10 transformed E. coli data from SE 158th Ave vs. cumulative precipitation from storm events prior to collection of grab samples for each sampling date. Two outliers $(10,000$ and 20,000 cfu/100 mL, both had 0 inches precipitation) exceeded plot range and were omitted.

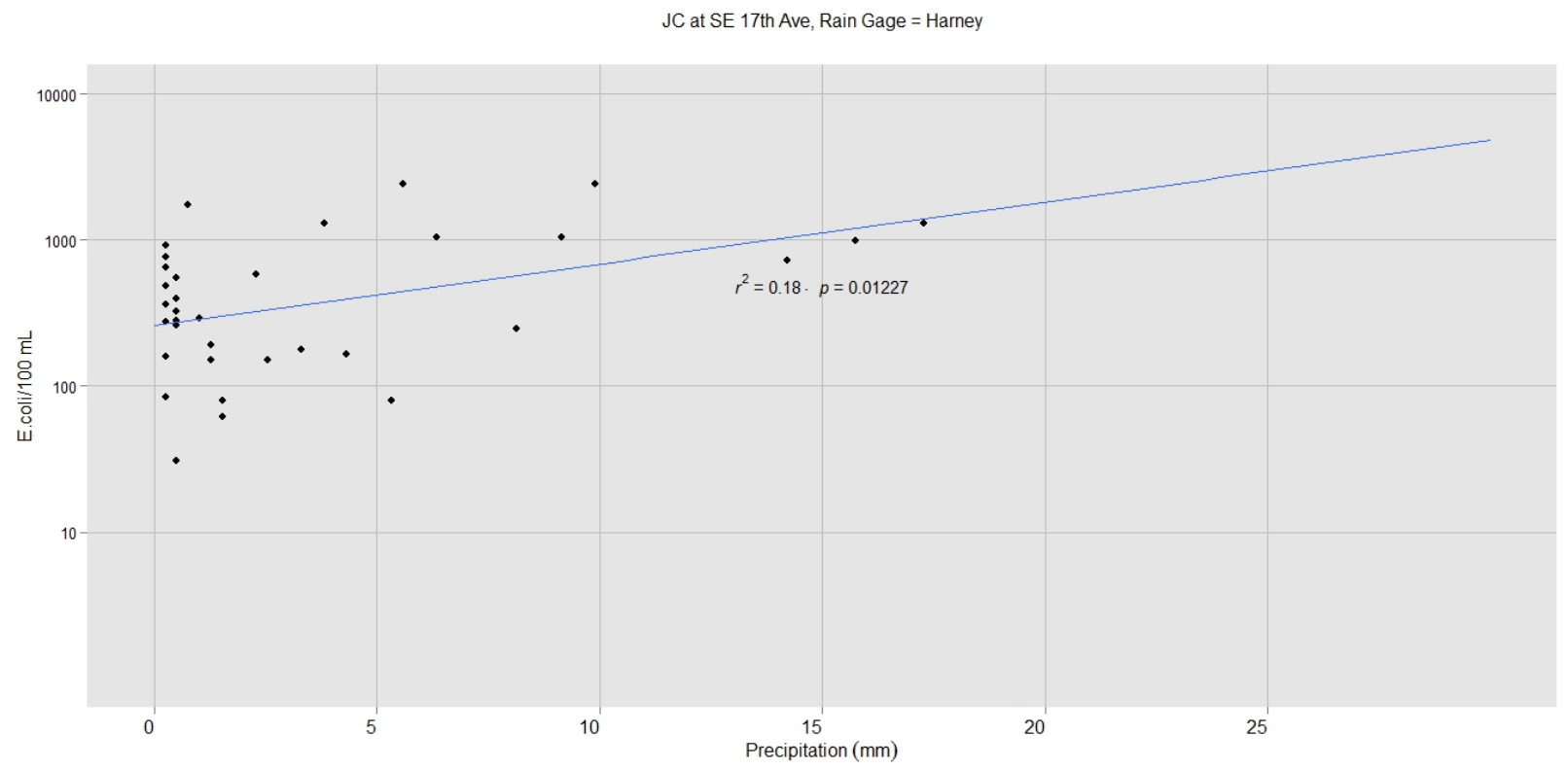

Figure 22. Fitted regression line for log base 10 transformed E. coli data from SE 17th Ave vs. cumulative precipitation from storm events prior to collection of grab samples for each sampling date. 
Results

Regression analysis was performed for E. coli concentrations vs cumulative precipitation from storm events prior to collection of an E. coli grab sample. Study sites consisted of Palmblad Ave, Jenne Rd, SE $158^{\text {th }}$ Ave, and SE $17^{\text {th }}$ Ave (Figure 4). Cottrell School rain gage was used for precipitation values at Palmblad Ave, Gresham Fire Dept. rain gage was used for Jenne Rd and SE $158^{\text {th }}$ Ave, and Harney rain gage was used for SE $17^{\text {th }}$ Ave (Figure 4). It was hypothesized that if runoff entered the stream, that there would be a log-linear relationship between in stream $E$. coli concentrations and the amount of precipitation during a storm event. Further it was assumed that study sites surrounded by urbanized regions within the watershed would exhibit a stronger log-linear relationship than sites surrounded by rural or agricultural land (Palmblad Ave and SE $158^{\text {th }}$ Ave). With the exception of SE $158^{\text {th }}$ Ave, all study sites were found to exhibit a statistically significant relationship $(\mathrm{p}<0.05)$ between $E$. coli and cumulative precipitation. Regression analysis for Palmblad Ave displayed the strongest log-linear relationship with 36\% of variance being explained by the model $\left(\mathrm{R}^{2}=0.357, \mathrm{p}<0.05\right)$ (Figure 19). Other models did not perform nearly as well. The regression model for Jenne Rd. and SE $17^{\text {th }}$ Ave both exhibited a weak loglinear relationship between $E$. coli and precipitation, with approximately $16\left(R^{2}=0.158, p<0.05\right)$ and $18 \%\left(\mathrm{R}^{2}=0.18, \mathrm{p}<0.05\right)$ of variance being explained by the models (Figure 20 and Figure 22 ). 


\section{Load Duration Curves}

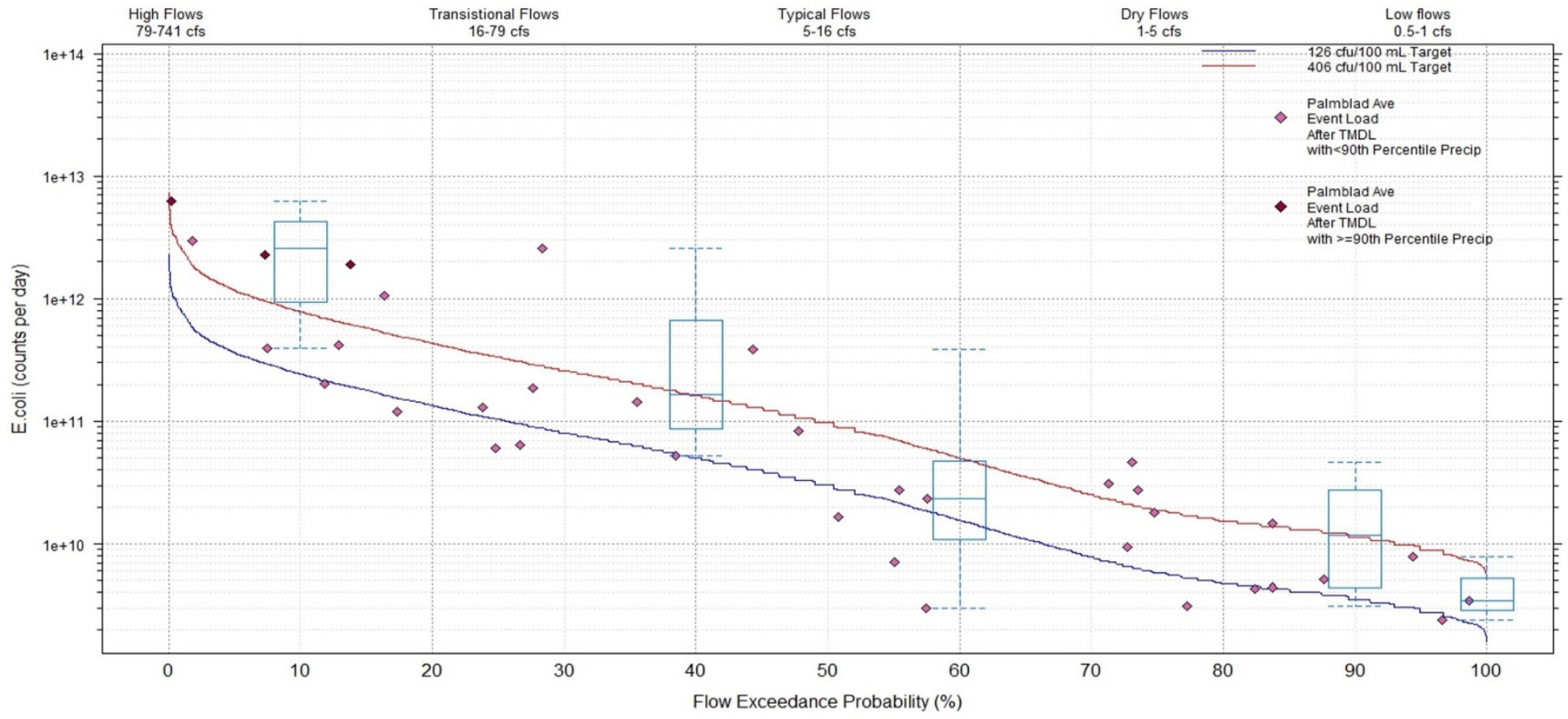

Figure 23. Load Duration Curve displaying event loads at Palmblad Ave before TMDL Implementation (1999-2006). Flow categories consist of the following intervals: 0-10\% for High Flows, 10-40\% for Transitional Flows, 40-60\% for Typical Flows, $60-90 \%$ for Dry Flows, and 90-100\% for Low Flows. Boxplots show the spread and median load for each of the 5 flow intervals.

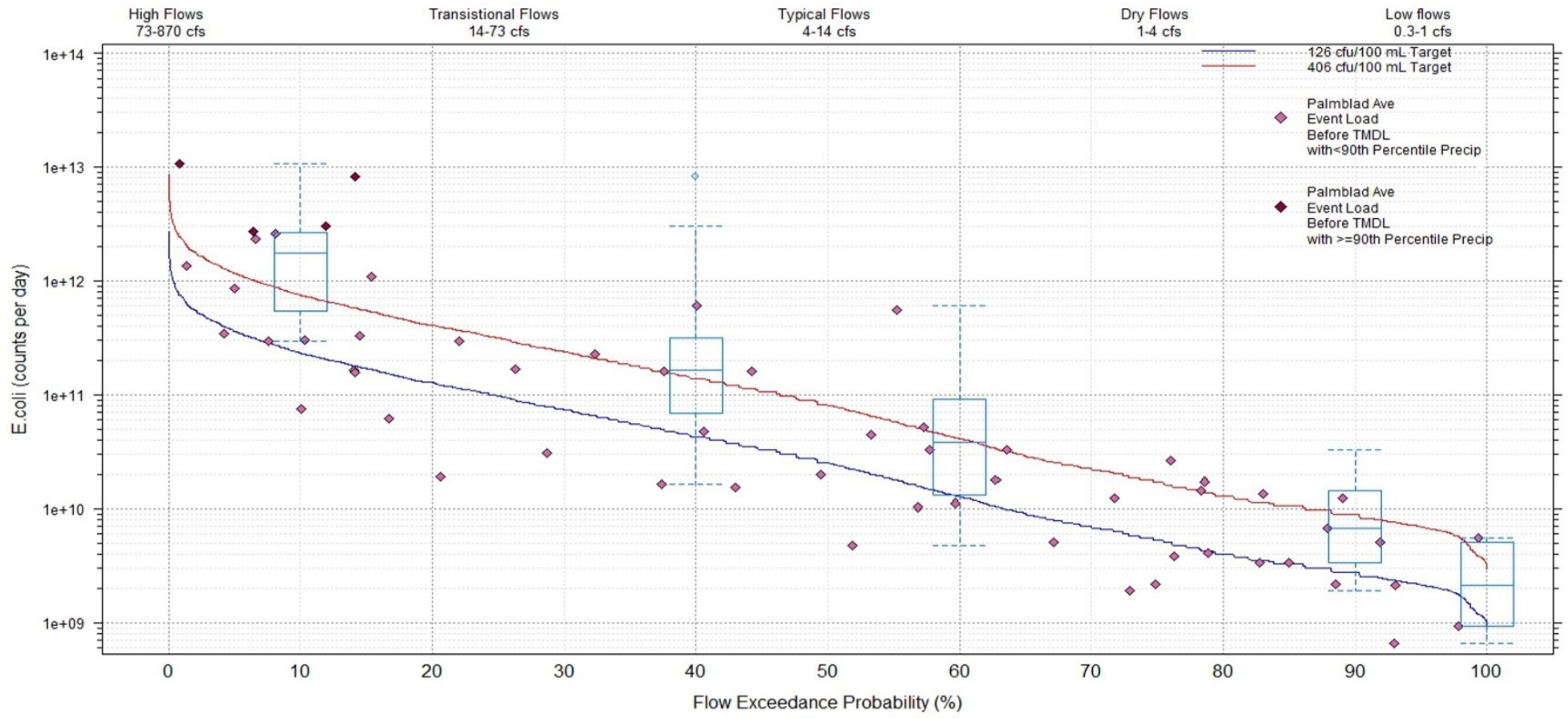

Figure 24. Load Duration Curve displaying event loads at Palmblad Ave after TMDL Implementation (2009-2016). Flow categories consist of the following intervals: 0-10\% for High Flows, 10-40\% for Transitional Flows, 40-60\% for Typical Flows, $60-90 \%$ for Dry Flows, and 90-100\% for Low Flows. Boxplots show the spread and median load for each of the 5 flow intervals. 


\begin{tabular}{|c|c|c|c|c|c|c|}
\hline \multicolumn{7}{|c|}{ Table 28. Johnson Creek at I } \\
\hline \multicolumn{2}{|c|}{$\begin{array}{l}\text { Total reduction needed } \\
=58 \%\end{array}$} & High Flows & $\begin{array}{l}\text { Transitional } \\
\text { Flows }\end{array}$ & $\begin{array}{l}\text { Typical } \\
\text { Flows }\end{array}$ & Dry Flows & Low Flows \\
\hline \multicolumn{2}{|c|}{ Loading Capacity (LC) } & $2.23 * 10^{11}$ & $4.27 * 10^{10}$ & $1.25 * 10^{10}$ & $2.76 * 10^{09}$ & $9.05 * 10^{08}$ \\
\hline \multicolumn{2}{|c|}{ Current Loading } & $9.25 * 10^{11}$ & $2.27 * 10^{11}$ & $3.32 * 10^{10}$ & $7.60 * 10^{09}$ & $2.05 * 10^{09}$ \\
\hline \multicolumn{2}{|c|}{ Max Load Event } & $1.06 * 10^{13}$ & $8.24 * 10^{12}$ & $5.59 * 10^{12}$ & $3.27 * 10^{10}$ & $5.52 * 10^{09}$ \\
\hline \multirow[t]{2}{*}{$\begin{array}{l}\text { \% reduction } \\
\text { needed }\end{array}$} & $\begin{array}{l}126 \\
\text { cfu/100 } \\
\mathrm{mL} \\
\text { standard }\end{array}$ & $76 \%$ & $81 \%$ & $62 \%$ & $64 \%$ & $56 \%$ \\
\hline & $\begin{array}{l}406 \\
\text { cfu/100 } \\
\mathrm{mL} \\
\text { standard }\end{array}$ & $77 \%$ & $93 \%$ & $90 \%$ & $3 \%$ & $31 \%$ \\
\hline \multicolumn{2}{|l|}{ TMDL } & $2.23 * 10^{11}$ & $4.27 * 10^{10}$ & $1.25 * 10^{10}$ & $2.76 * 10^{09}$ & $9.05 * 10^{08}$ \\
\hline
\end{tabular}

\begin{tabular}{|c|c|c|c|c|c|c|}
\hline \multicolumn{7}{|c|}{ Table 29. Johnson Creek at Palmblad Ave (After TMDL) } \\
\hline & & Range of Flc & & & & \\
\hline \multicolumn{2}{|c|}{$\begin{array}{l}\text { Total reduction needed } \\
=61 \%\end{array}$} & High Flows & $\begin{array}{l}\text { Transitional } \\
\text { Flows }\end{array}$ & $\begin{array}{l}\text { Typical } \\
\text { Flows }\end{array}$ & Dry Flows & Low Flows \\
\hline \multicolumn{2}{|c|}{ Loading Capacity (LC) } & $2.43 * 10^{11}$ & $5.03 * 10^{10}$ & $1.56 * 10^{10}$ & $3.53 * 10^{09}$ & $1.58 * 10^{09}$ \\
\hline \multicolumn{2}{|c|}{ Current Loading } & $2.01 * 10^{12}$ & $2.40 * 10^{11}$ & $2.55 * 10^{10}$ & $1.11 * 10^{10}$ & $4.00 * 10^{09}$ \\
\hline \multicolumn{2}{|c|}{ Max Load Event } & $6.20 * 10^{12}$ & $2.58 * 10^{12}$ & $2.12 * 10^{11}$ & $1.54 * 10^{11}$ & $8.87 * 10^{09}$ \\
\hline \multirow[t]{2}{*}{$\begin{array}{l}\text { \% reduction } \\
\text { needed }\end{array}$} & $\begin{array}{l}126 \\
\text { cfu/100 } \\
\mathrm{mL} \\
\text { standard }\end{array}$ & $88 \%$ & $79 \%$ & $39 \%$ & $68 \%$ & $60 \%$ \\
\hline & $\begin{array}{l}406 \\
\text { cfu/100 } \\
\text { mL } \\
\text { standard }\end{array}$ & $36 \%$ & $89 \%$ & $66 \%$ & $55 \%$ & $0 \%$ \\
\hline \multicolumn{2}{|l|}{ TMDL } & $2.43 * 10^{11}$ & $5.03 * 10^{10}$ & $1.56 * 10^{10}$ & $3.53 * 10^{09}$ & $1.58 * 10^{09}$ \\
\hline \multicolumn{2}{|c|}{$\begin{array}{l}\text { Reduction Needed } \\
\text { (126 standard) }\end{array}$} & & & & & \\
\hline \multicolumn{2}{|c|}{$\begin{array}{l}\text { Reduction Needed } \\
\text { (406 standard) }\end{array}$} & & & & & \\
\hline
\end{tabular}




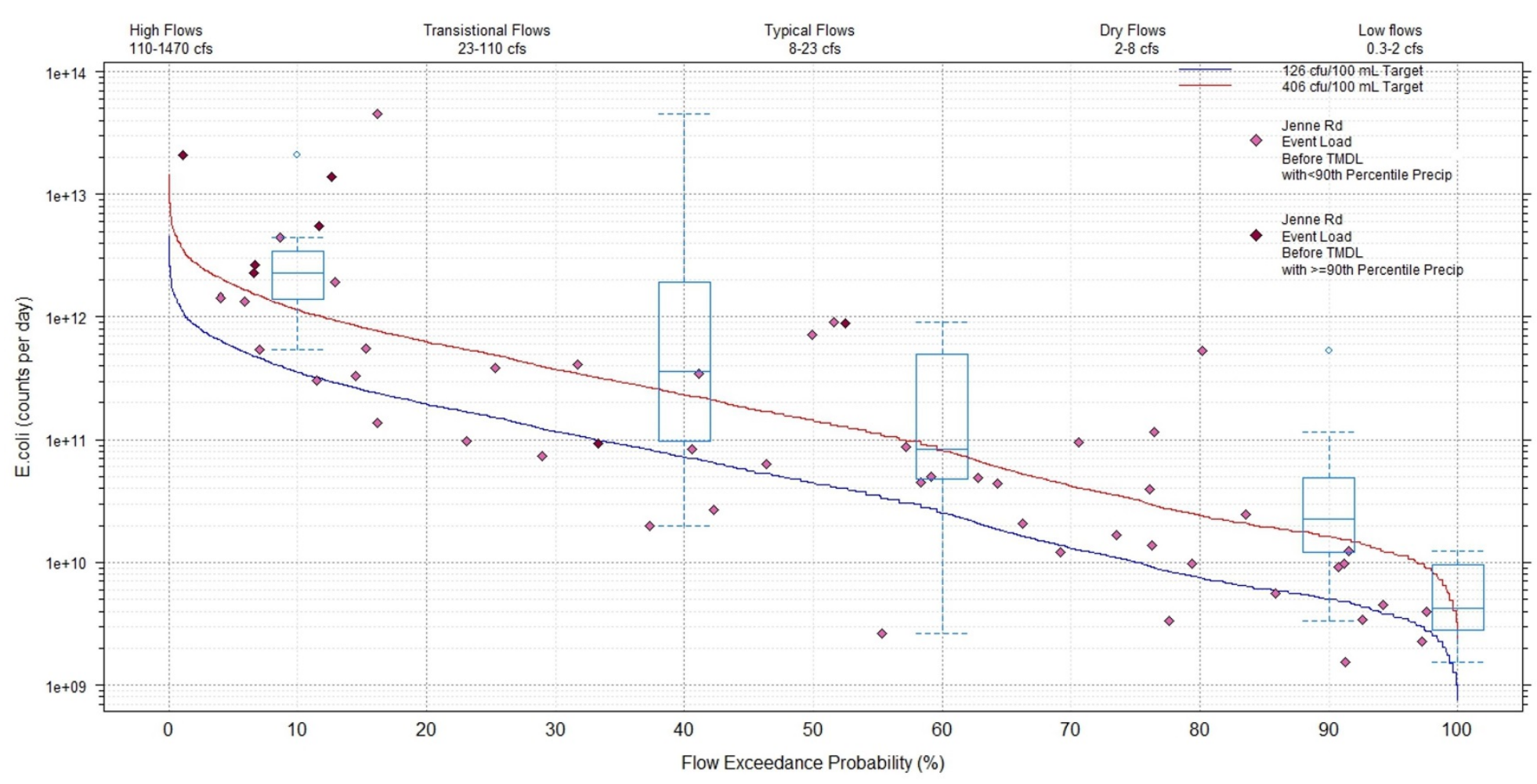

Figure 25. Load Duration Curve displaying event loads at Jenne Road before TMDL Implementation (1999-2006). Flow categories consist of the following intervals: 0-10\% for High Flows, 10-40\% for Transitional Flows, 40-60\% for Typical Flows, $60-90 \%$ for Dry Flows, and $90-100 \%$ for Low Flows. Boxplots show the spread and median load for each of the 5 flow intervals.

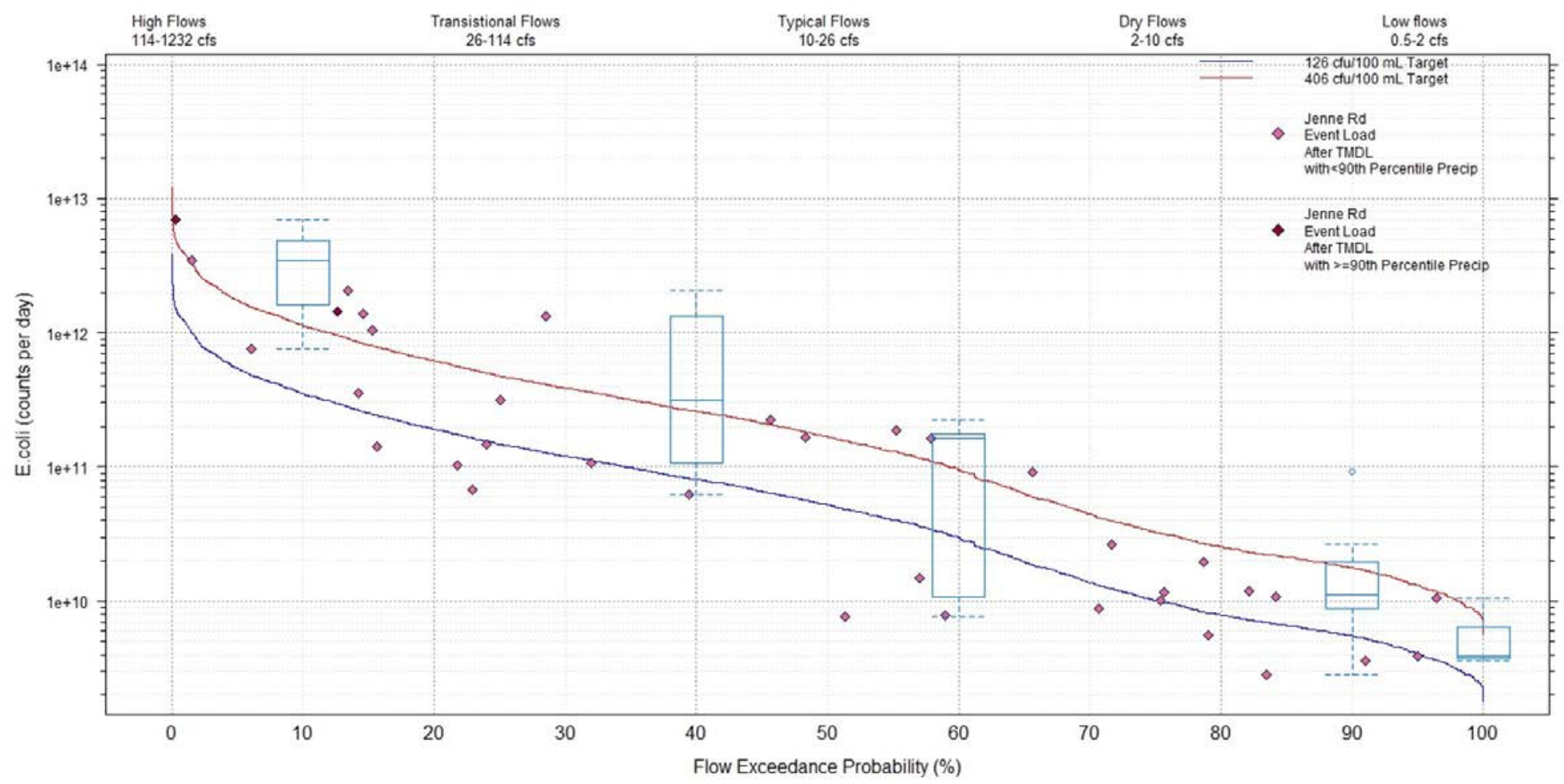

Figure 26. Load Duration Curve displaying event loads at Jenne Road after TMDL Implementation (2009-2016). Flow categories consist of the following intervals: $0-10 \%$ for High Flows, $10-40 \%$ for Transitional Flows, 40-60\% for Typical Flows, $60-90 \%$ for Dry Flows, and 90-100\% for Low Flows. Boxplots show the spread and median load for each of the 5 flow intervals. 


\begin{tabular}{|c|c|c|c|c|c|c|}
\hline & & Range of Fl & & & & \\
\hline \multicolumn{2}{|c|}{$\begin{array}{l}\text { Total reduction needed } \\
=72 \%\end{array}$} & High Flows & $\begin{array}{l}\text { Transitional } \\
\text { Flows }\end{array}$ & $\begin{array}{l}\text { Typical } \\
\text { Flows }\end{array}$ & Dry Flows & Low Flows \\
\hline \multicolumn{2}{|c|}{ Loading Capacity (LC) } & $3.40 * 10^{11}$ & $7.04 * 10^{10}$ & $2.50 * 10^{10}$ & $5.02 * 10^{09}$ & $7.58 * 10^{08}$ \\
\hline \multicolumn{2}{|c|}{ Current Loading } & $2.48 * 10^{12}$ & $5.76 * 10^{11}$ & $1.03 * 10^{11}$ & $2.72 * 10^{10}$ & $4.23 * 10^{09}$ \\
\hline \multicolumn{2}{|c|}{ Max Load Event } & $2.07 * 10^{13}$ & $4.51 * 10^{13}$ & $9.05 * 10^{11}$ & $5.34 * 10^{11}$ & $1.22 * 10^{10}$ \\
\hline \multirow[t]{2}{*}{$\begin{array}{l}\text { \% reduction } \\
\text { needed }\end{array}$} & $\begin{array}{l}126 \\
\text { cfu/100 } \\
\text { mL } \\
\text { standard }\end{array}$ & $86 \%$ & $88 \%$ & $76 \%$ & $82 \%$ & $82 \%$ \\
\hline & $\begin{array}{l}406 \\
\text { cfu/100 } \\
\text { mL } \\
\text { standard }\end{array}$ & $83 \%$ & $98 \%$ & $86 \%$ & $96 \%$ & $0 \%$ \\
\hline \multicolumn{2}{|l|}{ TMDL } & $3.40 * 10^{11}$ & $7.04 * 10^{10}$ & $2.50 * 10^{10}$ & $5.02 * 10^{09}$ & $7.58 * 10^{08}$ \\
\hline
\end{tabular}

\begin{tabular}{|c|c|c|c|c|c|c|}
\hline \multicolumn{7}{|c|}{ Table 31. Johnson Creek at Jenne Rd (After TMDL) } \\
\hline & & Range of Flc & & & & \\
\hline \multicolumn{2}{|c|}{$\begin{array}{l}\text { Total reduction needed } \\
=50 \%\end{array}$} & High Flows & $\begin{array}{l}\text { Transitional } \\
\text { Flows }\end{array}$ & $\begin{array}{l}\text { Typical } \\
\text { Flows }\end{array}$ & Dry Flows & Low Flows \\
\hline \multicolumn{2}{|c|}{ Loading Capacity (LC) } & $3.53 * 10^{11}$ & $8.11 * 10^{10}$ & $2.96 * 10^{10}$ & $5.53 * 10^{09}$ & $1.78 * 10^{09}$ \\
\hline \multicolumn{2}{|c|}{ Current Loading } & $2.64 * 10^{12}$ & $3.33 * 10^{11}$ & $5.20 * 10^{10}$ & $1.26 * 10^{10}$ & $5.30 * 10^{09}$ \\
\hline \multicolumn{2}{|c|}{ Max Load Event } & $6.93 * 10^{12}$ & $2.06 * 10^{12}$ & $6.24 * 10^{11}$ & $9.10^{*} 10^{10}$ & $1.05 * 10^{10}$ \\
\hline \multirow[t]{2}{*}{$\begin{array}{l}\text { \% reduction } \\
\text { needed }\end{array}$} & $\begin{array}{l}126 \\
\text { cfu/100 } \\
\mathrm{mL} \\
\text { standard }\end{array}$ & $86 \%$ & $76 \%$ & $43 \%$ & $56 \%$ & $66 \%$ \\
\hline & $\begin{array}{l}406 \\
\text { cfu/100 } \\
\text { mL } \\
\text { standard }\end{array}$ & $28 \%$ & $56 \%$ & $8 \%$ & $35 \%$ & $0 \%$ \\
\hline \multicolumn{2}{|l|}{ TMDL } & $3.58 * 10^{11}$ & $8.37 * 10^{10}$ & $3.30 * 10^{10}$ & $5.70 * 10^{09}$ & $1.78 * 10^{09}$ \\
\hline \multicolumn{2}{|c|}{$\begin{array}{l}\text { Reduction Needed } \\
\text { (126 standard) }\end{array}$} & -- & & & & 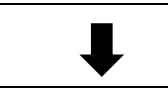 \\
\hline \multicolumn{2}{|c|}{$\begin{array}{l}\text { Reduction Needed } \\
\text { (406 standard) }\end{array}$} & & & & & -- \\
\hline
\end{tabular}




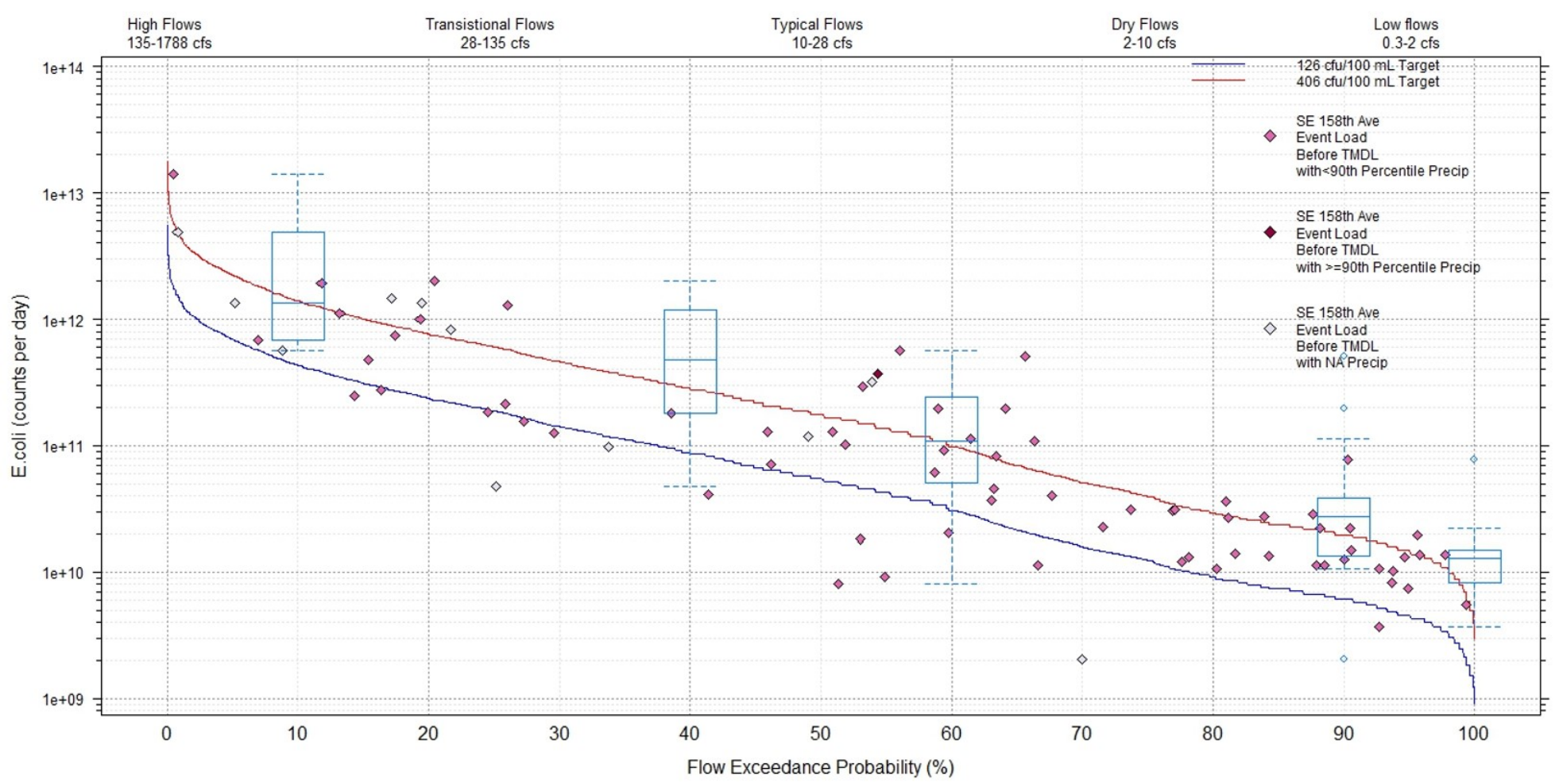

Figure 27. Load Duration Curve displaying event loads at SE 158th Ave before TMDL Implementation (1996-2006). Flow categories consist of the following intervals: 0-10\% for High Flows, 10-40\% for Transitional Flows, 40-60\% for Typical Flows, $60-90 \%$ for Dry Flows, and $90-100 \%$ for Low Flows. Boxplots show the spread and median load for each of the 5 flow intervals.

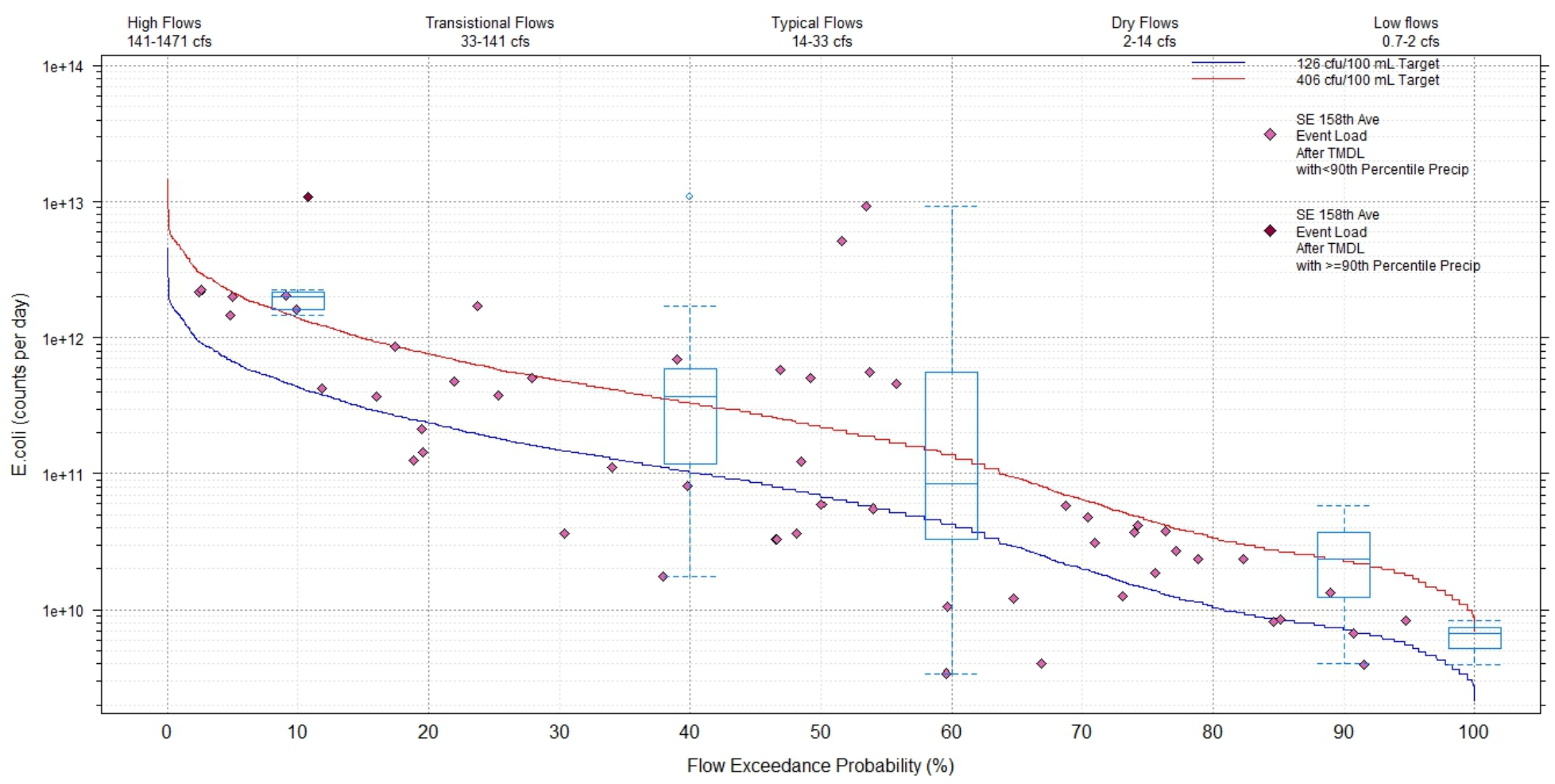

Figure 28. Load Duration Curve displaying event loads at SE 158th Ave after TMDL Implementation (2009-2015). Flow categories consist of the following intervals: 0-10\% for High Flows, 10-40\% for Transitional Flows, 40-60\% for Typical Flows, $60-90 \%$ for Dry Flows, and $90-100 \%$ for Low Flows. Boxplots show the spread and median load for each of the 5 flow intervals. 


\begin{tabular}{|c|c|c|c|c|c|c|}
\hline \multicolumn{2}{|c|}{ Table 32. Johnson Creek at } & \multicolumn{5}{|c|}{ Range of Flows } \\
\hline \multicolumn{2}{|c|}{$\begin{array}{l}\text { Total reduction needed } \\
=62 \%\end{array}$} & High Flows & $\begin{array}{l}\text { Transitional } \\
\text { Flows }\end{array}$ & $\begin{array}{l}\text { Typical } \\
\text { Flows }\end{array}$ & Dry Flows & Low Flows \\
\hline \multicolumn{2}{|c|}{ Loading Capacity (LC) } & $4.16 * 10^{11}$ & $8.57 * 10^{10}$ & $3.06 * 10^{10}$ & $6.12 * 10^{09}$ & $9.18 * 10^{08}$ \\
\hline \multicolumn{2}{|c|}{ Current Loading } & $2.04 * 10^{12}$ & $4.21 * 10^{11}$ & $8.22 * 10^{10}$ & $2.83 * 10^{10}$ & $1.24 * 10^{10}$ \\
\hline \multicolumn{2}{|c|}{ Max Load Event } & $1.40 * 10^{13}$ & $2.00 * 10^{12}$ & $5.68 * 10^{11}$ & $5.04 * 10^{11}$ & $7.78 * 10^{10}$ \\
\hline \multirow[t]{2}{*}{$\begin{array}{l}\text { \% reduction } \\
\text { needed }\end{array}$} & $\begin{array}{l}126 \\
\mathrm{cfu} / 100 \\
\mathrm{~mL} \\
\text { standard }\end{array}$ & $80 \%$ & $80 \%$ & $63 \%$ & $78 \%$ & $93 \%$ \\
\hline & $\begin{array}{l}406 \\
\mathrm{cfu} / 100 \\
\mathrm{~mL} \\
\text { standard }\end{array}$ & $58 \%$ & $63 \%$ & $77 \%$ & $87 \%$ & $75 \%$ \\
\hline \multicolumn{2}{|l|}{ TMDL } & $4.16 * 10^{11}$ & $8.57 * 10^{10}$ & $3.06 * 10^{10}$ & $6.12 * 10^{09}$ & $9.18 * 10^{08}$ \\
\hline
\end{tabular}

\begin{tabular}{|c|c|c|c|c|c|c|}
\hline \multicolumn{7}{|c|}{\begin{tabular}{l}
\multicolumn{2}{l}{ Table 33. Johnson Creek at SE 158th Ave (After } \\
Range of Flows
\end{tabular}} \\
\hline \multicolumn{2}{|c|}{$\begin{array}{l}\text { Total reduction needed } \\
=57 \%\end{array}$} & High Flows & $\begin{array}{l}\text { Transitional } \\
\text { Flows }\end{array}$ & $\begin{array}{l}\text { Typical } \\
\text { Flows }\end{array}$ & Dry Flows & Low Flows \\
\hline \multicolumn{2}{|c|}{ Loading Capacity (LC) } & $4.35 * 10^{11}$ & $1.01 * 10^{11}$ & $4.29 * 10^{10}$ & $7.05 * 10^{09}$ & $2.14 * 10^{09}$ \\
\hline \multicolumn{2}{|c|}{ Current Loading } & $1.89 * 10^{12}$ & $2.95 * 10^{11}$ & $1.45 * 10^{11}$ & $2.02 * 10^{10}$ & $6.04 * 10^{09}$ \\
\hline \multicolumn{2}{|c|}{ Max Load Event } & $2.25 * 10^{12}$ & $1.08 * 10^{13}$ & $9.24 * 10^{12}$ & $5.78 * 10^{10}$ & $8.31 * 10^{09}$ \\
\hline \multirow[t]{2}{*}{$\begin{array}{l}\text { \% reduction } \\
\text { needed }\end{array}$} & $\begin{array}{l}126 \\
\text { cfu/100 } \\
\text { mL } \\
\text { standard }\end{array}$ & $77 \%$ & $66 \%$ & $71 \%$ & $65 \%$ & $65 \%$ \\
\hline & $\begin{array}{l}406 \\
\text { cfu/100 } \\
\mathrm{mL} \\
\text { standard }\end{array}$ & $0 \%$ & $88 \%$ & $98 \%$ & $0 \%$ & $0 \%$ \\
\hline \multicolumn{2}{|l|}{ TMDL } & $4.35 * 10^{11}$ & $1.01 * 10^{11}$ & $4.29 * 10^{10}$ & $7.05 * 10^{09}$ & $2.14 * 10^{09}$ \\
\hline \multicolumn{2}{|c|}{$\begin{array}{l}\text { Reduction Needed } \\
\text { (126 standard) }\end{array}$} & & & & & \\
\hline \multicolumn{2}{|c|}{$\begin{array}{l}\text { Reduction Needed } \\
\text { (406 standard) }\end{array}$} & & & & & \\
\hline
\end{tabular}




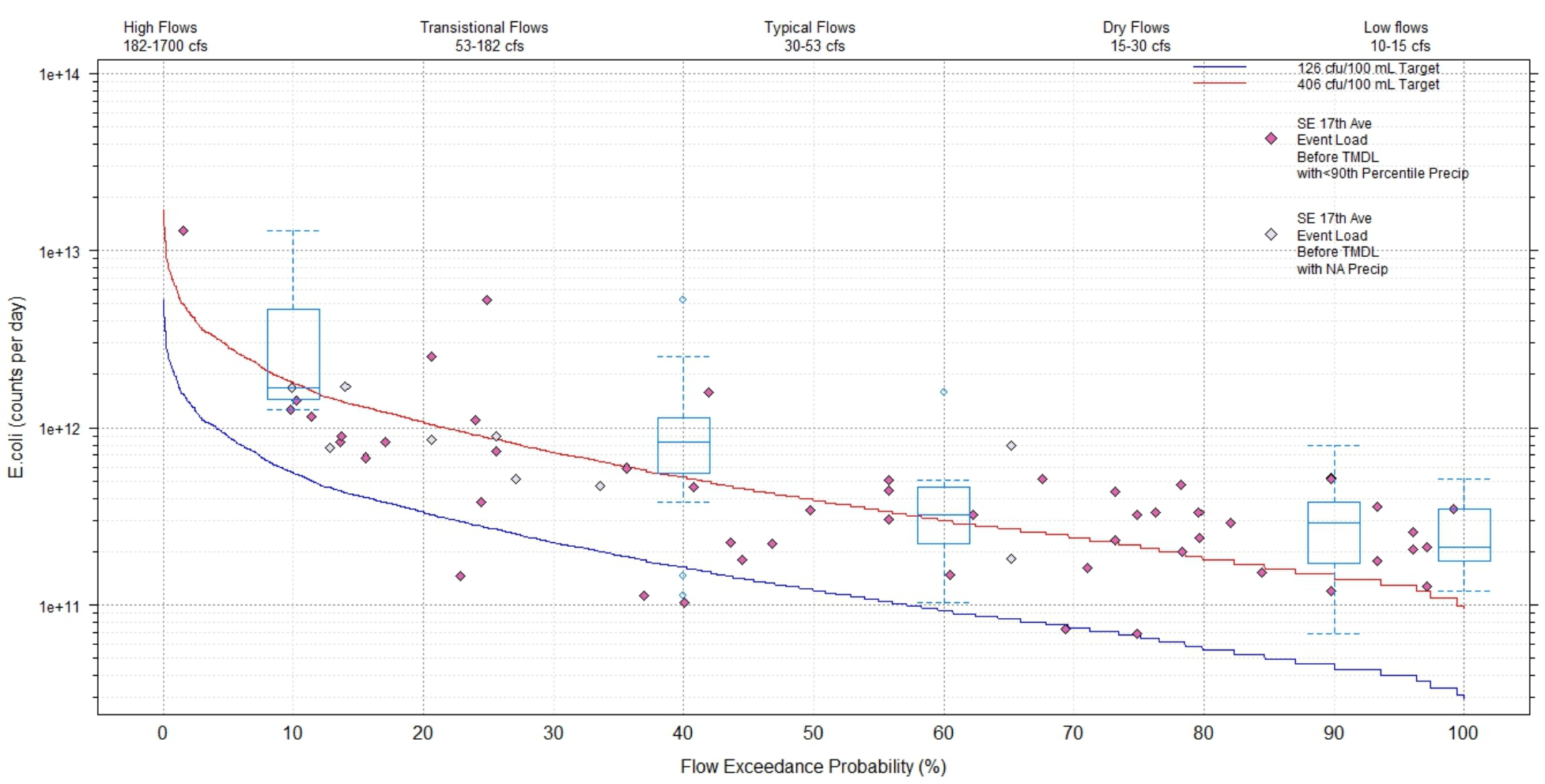

Figure 29. Load Duration Curve displaying event loads at SE $17^{\text {th }}$ Ave before TMDL Implementation (1996-2006). Flow categories consist of the following intervals: 0-10\% for High Flows, 10-40\% for Transitional Flows, 40-60\% for Typical Flows, $60-90 \%$ for Dry Flows, and $90-100 \%$ for Low Flows. Boxplots show the spread and median load for each of the 5 flow intervals.

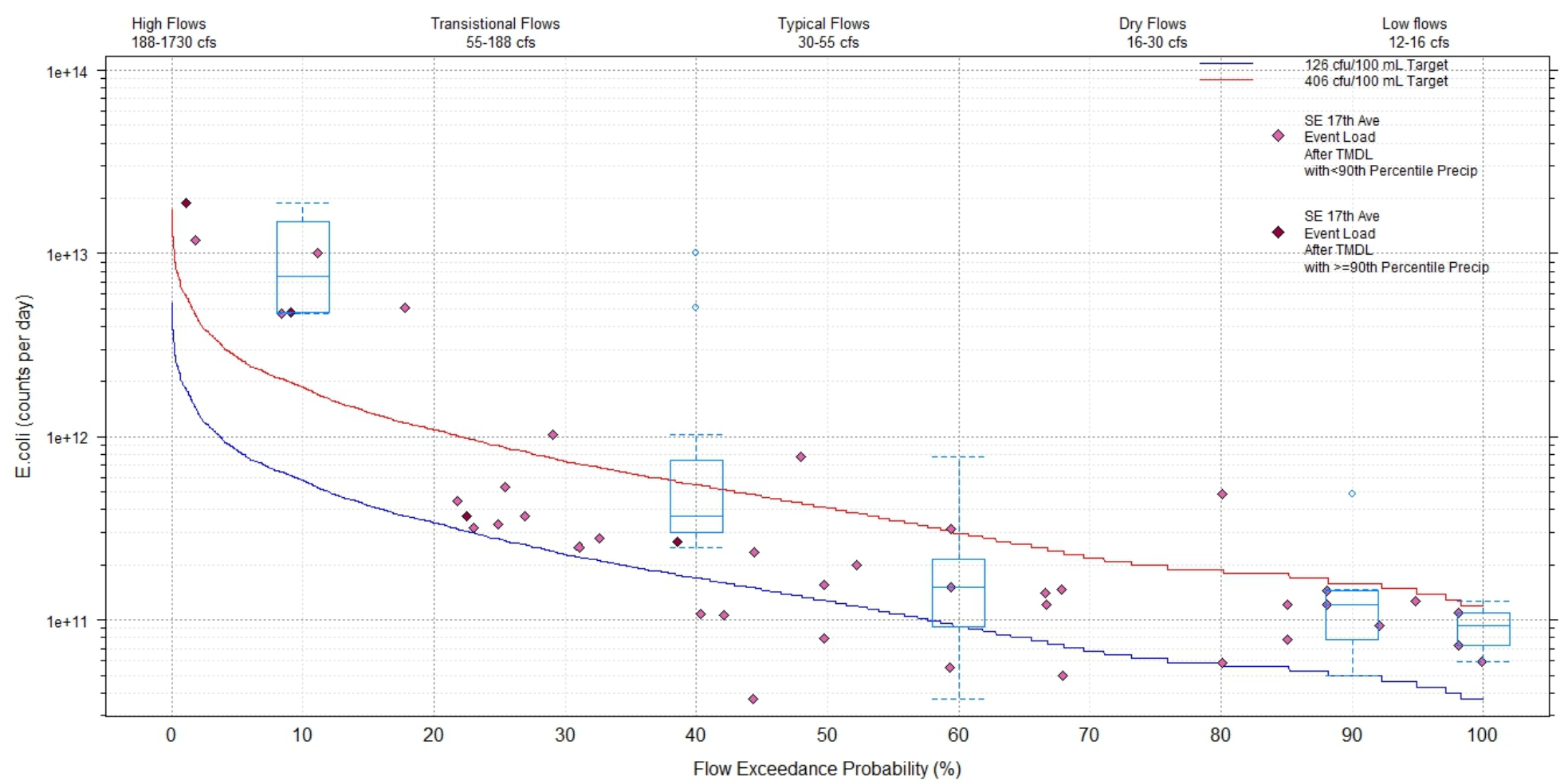

Figure 30. Load Duration Curve displaying event loads at SE $17^{\text {th }}$ Ave after TMDL Implementation (2009-2016). Flow categories consist of the following intervals: 0-10\% for High Flows, 10-40\% for Transitional Flows, 40-60\% for Typical Flows, $60-90 \%$ for Dry Flows, and $90-100 \%$ for Low Flows. Boxplots show the spread and median load for each of the 5 flow interval. 


\begin{tabular}{|c|c|c|c|c|c|c|}
\hline \multicolumn{7}{|c|}{ Table 34. Johnson Creek at SE 17th Ave (Before TMDL) } \\
\hline & & Range of Fl & & & & \\
\hline \multicolumn{2}{|c|}{$\begin{array}{l}\text { Total reduction needed } \\
=73 \%\end{array}$} & High Flows & $\begin{array}{l}\text { Transitional } \\
\text { Flows }\end{array}$ & $\begin{array}{l}\text { Typical } \\
\text { Flows }\end{array}$ & Dry Flows & Low Flows \\
\hline \multicolumn{2}{|c|}{ Loading Capacity (LC) } & $5.64 * 10^{11}$ & $1.63 * 10^{11}$ & $9.24 * 10^{10}$ & $4.62 * 10^{10}$ & $3.00 * 10^{10}$ \\
\hline \multicolumn{2}{|c|}{ Current Loading } & $3.00 * 10^{12}$ & $7.79 * 10^{11}$ & $3.31 * 10^{11}$ & $2.55 * 10^{11}$ & $2.33 * 10^{11}$ \\
\hline \multicolumn{2}{|c|}{ Max Load Event } & $1.28 * 10^{13}$ & $5.28 * 10^{12}$ & $1.59 * 10^{12}$ & $7.92 * 10^{11}$ & $5.13^{*} 10^{11}$ \\
\hline \multirow[t]{2}{*}{$\begin{array}{l}\text { \% reduction } \\
\text { needed }\end{array}$} & $\begin{array}{l}126 \\
\text { cfu/100 } \\
\text { mL } \\
\text { standard }\end{array}$ & $81 \%$ & $79 \%$ & $72 \%$ & $82 \%$ & $87 \%$ \\
\hline & $\begin{array}{l}406 \\
\text { cfu/100 } \\
\mathrm{mL} \\
\text { standard }\end{array}$ & $61 \%$ & $83 \%$ & $69 \%$ & $66 \%$ & $71 \%$ \\
\hline \multicolumn{2}{|l|}{ TMDL } & $5.64 * 10^{11}$ & $1.63 * 10^{11}$ & $9.24 * 10^{10}$ & $4.62 * 10^{10}$ & $3.00 * 10^{10}$ \\
\hline
\end{tabular}

\begin{tabular}{|c|c|c|c|c|c|c|}
\hline \multicolumn{7}{|c|}{\begin{tabular}{l|l}
\multicolumn{2}{|c|}{ Table 35. Johnson Creek at SE 17th Ave (After TMDL) } \\
Range of Flows
\end{tabular}} \\
\hline \multicolumn{2}{|c|}{$\begin{array}{l}\text { Total reduction needed } \\
=56 \%\end{array}$} & High Flows & $\begin{array}{l}\text { Transitional } \\
\text { Flows }\end{array}$ & $\begin{array}{l}\text { Typical } \\
\text { Flows }\end{array}$ & Dry Flows & Low Flows \\
\hline \multicolumn{2}{|c|}{ Loading Capacity (LC) } & $5.79 * 10^{11}$ & $1.69 * 10^{11}$ & $9.24 * 10^{10}$ & $4.93 * 10^{10}$ & $3.70 * 10^{10}$ \\
\hline \multicolumn{2}{|c|}{ Current Loading } & $8.43 * 10^{12}$ & $6.23 * 10^{11}$ & $1.43 * 10^{11}$ & $1.19 * 10^{11}$ & $8.88 * 10^{10}$ \\
\hline \multicolumn{2}{|c|}{ Max Load Event } & $1.90 * 10^{13}$ & $1.00 * 10^{13}$ & $7.82 * 10^{11}$ & $4.86 * 10^{11}$ & $1.26 * 10^{11}$ \\
\hline \multirow[t]{2}{*}{$\begin{array}{l}\text { \% reduction } \\
\text { needed }\end{array}$} & $\begin{array}{l}126 \\
\mathrm{cfu} / 100 \\
\mathrm{~mL} \\
\text { standard }\end{array}$ & $93 \%$ & $72 \%$ & $35 \%$ & $59 \%$ & $59 \%$ \\
\hline & $\begin{array}{l}406 \\
\mathrm{cfu} / 100 \\
\mathrm{~mL} \\
\text { standard }\end{array}$ & $69 \%$ & $83 \%$ & $44 \%$ & $61 \%$ & $0 \%$ \\
\hline \multicolumn{2}{|l|}{ TMDL } & $5.58 * 10^{11}$ & $1.60 * 10^{11}$ & $8.63 * 10^{10}$ & $4.93 * 10^{10}$ & $3.70 * 10^{10}$ \\
\hline \multicolumn{2}{|c|}{$\begin{array}{l}\text { Reduction Needed } \\
\text { (126 standard) }\end{array}$} & & & & & \\
\hline \multicolumn{2}{|c|}{$\begin{array}{l}\text { Reduction Needed } \\
\text { (406 standard) }\end{array}$} & 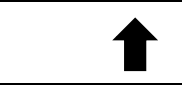 & -- & & & \\
\hline
\end{tabular}


Results

Overall changes in loading for the $126 \mathrm{cfu} / 100 \mathrm{~mL}$ standard before and after the TMDL exhibited similar findings to the Seasonal Mann Kendall trend test for bacterial concentrations. Palmblad and SE $158^{\text {th }}$ Ave displayed minor changes in overall loading from before and after implementation of TMDL actions (3\% and 5\% change respectively) (Table 28,Table 29,Table 32,Table 33). These findings agree with the results from the Seasonal Mann Kendall trend test for bacteria, which showed no significant changes in bacterial concentrations over the last two decades for either Palmblad or SE $158^{\text {th }}$ Ave (Figure 12) and (Figure 14). Changes in overall loading for SE $17^{\text {th }}$ Ave and Jenne Rd. on the other hand, changed more substantially with $17 \%$ and $22 \%$ differences (Figure 25,Figure 26,Figure 29,Figure 30) in loading following implementation of TMDL actions (both improvements in loading conditions). Findings from Seasonal Mann Kendall once again showed no contradictions to the results from loading analysis, as both Jenne Rd. and SE $17^{\text {th }}$ Ave (Figure 13) and (Figure 15) were found to be significantly decreasing over time (19992016 and 1996-2016 respectively).

When assessing changes in loading before and after the implementation of TMDL actions for individual flow regimes, many similarities were found between Jenne Rd. and SE $17^{\text {th }}$ Ave. Both Jenne Rd. and SE $17^{\text {th }}$ Ave showed improvements in loading conditions (or no change) for both the 126 and 406/100 mL standards in all flow regimes with the exception of high flows (Table 30, Table 31, Table 34, Table 35). Conversely, loading conditions for high flows at Jenne Rd were shown to not change for the $126 \mathrm{cfu} / 100 \mathrm{~mL}$ standard and to decrease for the $406 \mathrm{cfu} / 100$ $\mathrm{mL}$ standard (55\% decrease). While loading conditions during high flows at SE $17^{\text {th }}$ Ave for both the 126 and 406/100 mL standards were shown to slightly increase (12\% and 8\% increase respectively). 
With the exception of Palmblad Ave (Table 28) and (Table 29) an assessment of loading conditions for individual flow regimes found substantial improvements in loading conditions at all sites (Table 30,Table 31,Table 32,Table 33,Table 34,Table 35) for dry and low flows (both 126 cfu/100 mL and $406 \mathrm{cfu} / 100 \mathrm{~mL}$ standards). Further, loading conditions during typical flows at Palmblad, Jenne Rd, and SE $17^{\text {th }}$ Ave, had the greatest improvements towards meeting the 126 cfu/100 mL standard, with 23\%, 33\%, and 37\% decreases respectively (Table 28, Table 29 Table 30,Table 31, Table 34,Table 35). The least improvements in loading conditions needed to meet the $126 \mathrm{cfu} / 100 \mathrm{~mL}$ standard occurred during transitional flows at Palmblad and SE $17^{\text {th }}$ Ave and during high flows at Jenne Rd and SE $158^{\text {th }}$ Ave (2\%, 7\%, 0\%, and 3\% respectively).

Improvements in loading conditions needed to meet the $406 \mathrm{cfu} / 100 \mathrm{~mL}$ standard showed less consistency between sites than conditions for the $126 \mathrm{cfu} / 100 \mathrm{~mL}$ standard. It was found that with the exception of Jenne Rd (greatest improvement occurred during typical flows) the most substantial improvements towards the $406 \mathrm{cfu} / 100 \mathrm{~mL}$ standard were occurring during dry and low flows, with 31-87\% decreases respectively (Table 28, Table 29, Table 32, Table 33, Table 34, Table 35). Similar to the findings for the $126 \mathrm{cfu} / 100 \mathrm{~mL}$ standard, transitional flows were found to have the least amount of improvement towards meeting the $406 \mathrm{cfu} / 100 \mathrm{~mL}$ standard, with as low as $0 \%$ and $4 \%$, loading reductions, and a threshold of $43 \%$ for loading reductions (Table 28, Table 29 Table 30,Table 31, Table 34,Table 35). Although typical flows may occur during both the wet and dry seasons, putting these findings together indicates that improvements in water quality are predominately occurring during dry weather conditions, while minor improvements are occurring during wet weather events. 


\section{Pollutant Load Reduction Modeling}

Table 36. Structural BMPs used in Pollutant Load Reduction models, acreage listed for each BMP type as well as installation dates may or may not reflect actual allotment or first and last implementation date due to delineation difficulties and gaps in data.

\begin{tabular}{|c|c|c|c|c|}
\hline AGENCY & $\begin{array}{l}\text { BEST } \\
\text { MANAGEMENT } \\
\text { PRACTICES (BMPs) }\end{array}$ & $\begin{array}{l}\text { TREATED } \\
\text { AREA } \\
\text { (Acres) }\end{array}$ & $\begin{array}{l}\text { Year First } \\
\text { Implemented }\end{array}$ & $\begin{array}{l}\text { Year Last } \\
\text { Implemented }\end{array}$ \\
\hline \multirow{8}{*}{$\begin{array}{l}\text { City of Gresham } \\
\text { (MS4) }\end{array}$} & Porous Pavement & 4 & 2012 & 2013 \\
\hline & Planter Rain Garden & 6 & 2008 & 2016 \\
\hline & Wet Retention Ponds & 52 & 1990 & 2006 \\
\hline & Filter-Dry Ponds & 12 & - & - \\
\hline & $\begin{array}{l}\text { Filters (Leaf, Sand, } \\
\text { Other) }\end{array}$ & 46 & 2009 & 2014 \\
\hline & Swales/Filters & 81 & - & - \\
\hline & Swales & 45 & 1993 & 2015 \\
\hline & Dry Detention Ponds & 87 & 1992 & 2010 \\
\hline \multirow{3}{*}{$\begin{array}{l}\text { City of Milwaukie } \\
\text { (MS4) }\end{array}$} & Infiltration Raingarden & 5 & 2010 & 2015 \\
\hline & Detention Pond & 71 & - & - \\
\hline & Filters & 6 & - & - \\
\hline \multirow[t]{3}{*}{ CCSD\#1 (MS4) ${ }^{1}$} & Dry Detention Pond & 319 & - & - \\
\hline & Swale & 8 & - & - \\
\hline & Wet Retention Pond & 53 & - & - \\
\hline \multirow[t]{8}{*}{$\begin{array}{l}\text { City of Portland } \\
\text { (MS4) }\end{array}$} & $\begin{array}{l}\text { Filter (Leaf, Sand, } \\
\text { Other) }\end{array}$ & 61 & 2001 & 2014 \\
\hline & Wet Retention Ponds & 154 & 1997 & 2012 \\
\hline & Infiltration Basin & 29 & 2011 & 2013 \\
\hline & Infiltration Trench & 1 & - & - \\
\hline & Infiltration Planter-Box & 1 & 2001 & 2007 \\
\hline & Soakage Trench & 9 & 1999 & - \\
\hline & Porous Pavement & 2 & 2003 & 2014 \\
\hline & Swale & 515 & 1995 & 2013 \\
\hline
\end{tabular}

1. Model results and coverage area of structural BMPs from (WES, 2015) 
City of Gresham

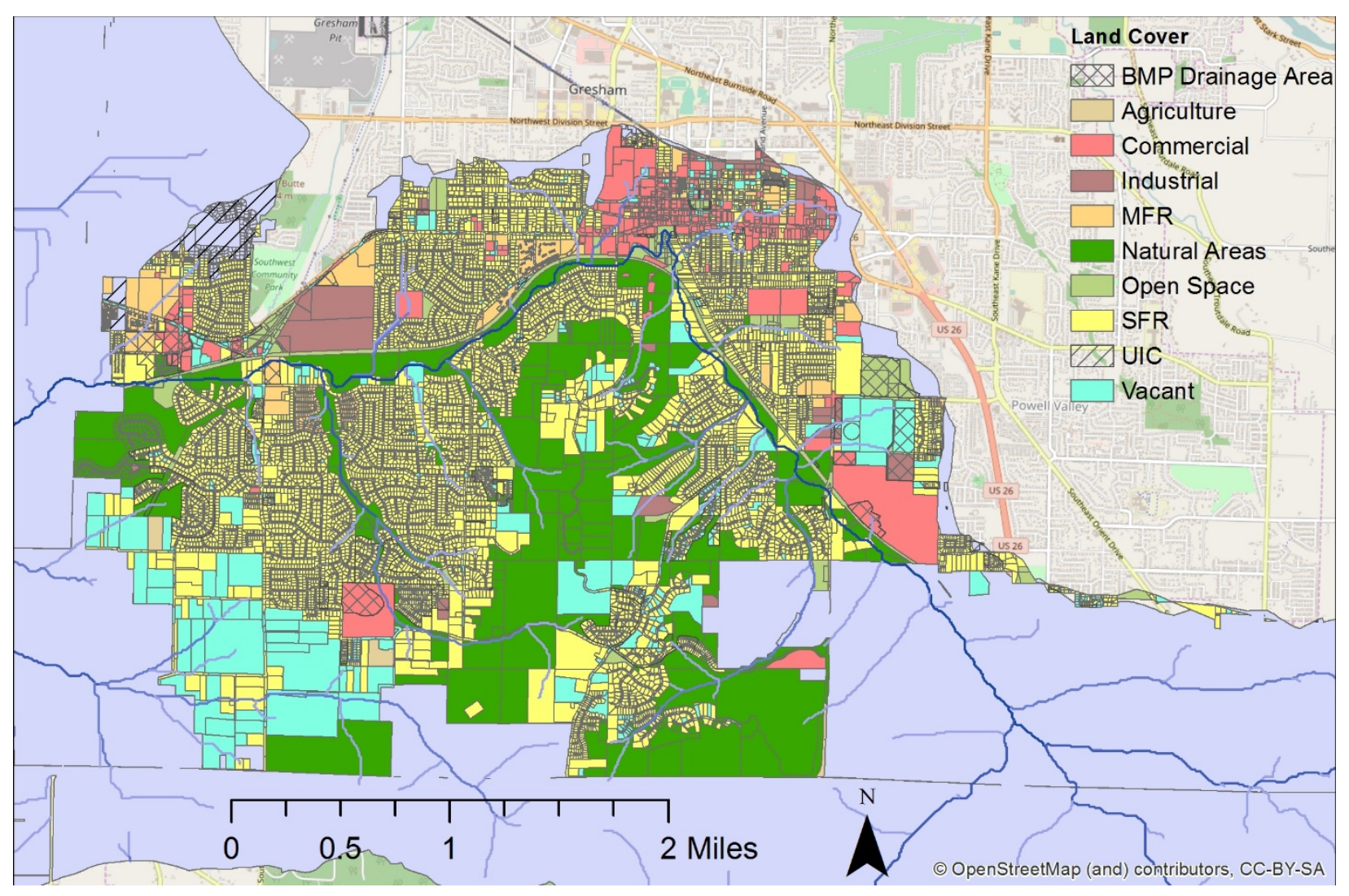

Figure 31. Map of zoning categories and treated areas for Gresham MS4 boundary within Johnson Creek.

Table 37. COG impervious surface percentages and runoff coefficients by land use for estimating 2015 bacterial loading. Land use/Land cover data presented is from 2008.

\begin{tabular}{|c|c|c|c|c|c|}
\hline $\begin{array}{c}\text { Land Use } \\
\text { Category }\end{array}$ & Impervious \% & $\begin{array}{c}\text { Runoff } \\
\text { Coefficient }\end{array}$ & $\begin{array}{c}\text { Total Area } \\
\text { (Acres) }\end{array}$ & $\begin{array}{c}\text { Treated Area } \\
\text { (Acres) }\end{array}$ & $\begin{array}{c}\text { Annual } \\
\text { Precipitation } \\
\text { (in/yr) }\end{array}$ \\
\hline Agriculture & 11 & 0.149 & 17 & 0 & 54 \\
\hline Industrial & 33 & 0.347 & 135 & 16 & 51 \\
\hline Open Space & 21 & 0.239 & 175 & 27 & 52 \\
\hline Commercial & 53 & 0.527 & 388 & 41 & 53 \\
\hline Residential & 39 & 0.401 & 2415 & 174 & 52 \\
\hline $\begin{array}{c}\text { Multi Family } \\
\text { Res }\end{array}$ & 61 & 0.599 & 204 & 22 & 50 \\
\hline Undeveloped & 17 & 0.203 & 712 & 39 & 53 \\
\hline Natural Area & $\sim 0$ & $\sim 0$ & 1362 & 1362 & - \\
\hline
\end{tabular}

1. Runoff Coefficient is calculated from the EPA equation: $\mathrm{Rv}=0.05+0.009$ (\% impervious) 
Table 38. Land use event mean storm concentrations (EMCs) of E. coli utilized by all Oregon Association of Clean Water Agencies (ACWA) which includes the following DMAs within the Johnson Creek watershed: Portland, Gresham, Milwaukie, and Happy Valley.

\begin{tabular}{|l|c|c|c|c|}
\hline \multirow{3}{*}{ Pollutant } & \multirow{2}{*}{ Land Use } & \multicolumn{3}{|c|}{ Land Use EMCs } \\
\cline { 3 - 5 } & $\begin{array}{c}\text { 95\% Lower Conf } \\
\text { Interval }\end{array}$ & Geomean & $\begin{array}{c}\text { 95\% Upper Conf } \\
\text { Interval }\end{array}$ \\
\hline \multirow{4}{*}{ E. coli } & Agriculture & 573 & 1247 & 2409 \\
\cline { 2 - 5 } & Industrial & 154 & 438 & 1004 \\
\cline { 2 - 5 } & Open Space & 57 & 87 & 124 \\
\cline { 2 - 5 } & Undeveloped & 57 & 87 & 124 \\
\cline { 2 - 5 } & Commercial & 573 & 1247 & 2409 \\
\cline { 2 - 5 } & Residential & 970 & 1656 & 2651 \\
\cline { 2 - 5 } & Multi Family Res & 970 & 1656 & 2651 \\
\hline
\end{tabular}

Table 39. COG 2015 bacterial loading with and without BMPs and the associated \% load reduction from implementation of BMPs.

\begin{tabular}{|c|c|c|c|c|c|c|c|c|}
\hline \multirow{3}{*}{$\begin{array}{l}\text { Land Use } \\
\text { Category }\end{array}$} & \multicolumn{6}{|c|}{$\begin{array}{l}2015 \text { Bacterial Loading } \\
\text { (Colonies/Year) }\end{array}$} & \multirow{3}{*}{$\begin{array}{l}\text { WLA } \\
\text { Mean }\end{array}$} & \multirow{3}{*}{$\begin{array}{c}\begin{array}{c}\text { BMP } \\
\text { Load } \\
\text { Reduction } \\
(\%)\end{array} \\
\begin{array}{c}\text { WLA }=78 \% \\
\text { Reduction }\end{array} \\
\end{array}$} \\
\hline & \multicolumn{3}{|c|}{ Without BMPs } & \multicolumn{3}{|c|}{ With BMPs } & & \\
\hline & $\mathbf{L C I}^{1}$ & Mean & $\mathrm{UCI}^{2}$ & $\mathbf{L C I}^{1}$ & Mean & $\mathrm{UCI}^{2}$ & & \\
\hline Agriculture & $7.3 \mathrm{E}+10$ & $1.6 \mathrm{E}+11$ & $3.1 \mathrm{E}+11$ & $7.3 \mathrm{E}+10$ & $1.6 \mathrm{E}+11$ & $3.1 \mathrm{E}+11$ & $3.5 \mathrm{E}+10$ & $0 \%$ \\
\hline Industrial & $3.4 \mathrm{E}+11$ & $9.7 \mathrm{E}+11$ & $2.2 \mathrm{E}+12$ & $3.3 E+11$ & $9.0 \mathrm{E}+11$ & $2.0 \mathrm{E}+12$ & $1.9 \mathrm{E}+11$ & $7 \%$ \\
\hline Open Space & $1.2 \mathrm{E}+11$ & $1.8 \mathrm{E}+11$ & $2.5 \mathrm{E}+11$ & $1.1 \mathrm{E}+11$ & $1.7 \mathrm{E}+11$ & $2.4 \mathrm{E}+11$ & $4.0 \mathrm{E}+10$ & $6 \%$ \\
\hline Commercial & $5.7 \mathrm{E}+12$ & $1.3 \mathrm{E}+13$ & $2.4 \mathrm{E}+13$ & $5.1 \mathrm{E}+12$ & $1.1 \mathrm{E}+13$ & $2.2 \mathrm{E}+13$ & $2.8 \mathrm{E}+12$ & $15 \%$ \\
\hline Residential & $4.5 \mathrm{E}+13$ & $7.7 \mathrm{E}+13$ & $1.2 \mathrm{E}+14$ & $4.4 \mathrm{E}+13$ & $7.5 \mathrm{E}+13$ & $1.2 \mathrm{E}+14$ & $1.7 \mathrm{E}+13$ & $3 \%$ \\
\hline $\begin{array}{l}\text { Multi Family } \\
\text { Res }\end{array}$ & $5.1 \mathrm{E}+12$ & $9.4 \mathrm{E}+12$ & $1.5 \mathrm{E}+13$ & $4.8 \mathrm{E}+12$ & $8.8 \mathrm{E}+12$ & $1.4 \mathrm{E}+13$ & $2.1 \mathrm{E}+12$ & $6 \%$ \\
\hline Undeveloped & $4.0 \mathrm{E}+11$ & $6.2 \mathrm{E}+11$ & $8.8 \mathrm{E}+11$ & $3.9 \mathrm{E}+11$ & $6.1 \mathrm{E}+11$ & $8.6 \mathrm{E}+11$ & $1.4 \mathrm{E}+11$ & $2 \%$ \\
\hline Total & $5.7 \mathrm{E}+13$ & $1.0 \mathrm{E}+14$ & $1.7 \mathrm{E}+14$ & $5.5 \mathrm{E}+13$ & $9.5 \mathrm{E}+13$ & $1.6 \mathrm{E}+14$ & $2.2 \mathrm{E}+13$ & $5 \%$ \\
\hline
\end{tabular}

1. $\quad$ LCI $=$ lower value of $95 \%$ confidence interval for land use based stormwater runoff concentrations

2. $\quad$ UCI =upper value of $95 \%$ confidence interval for land use based stormwater runoff concentrations

3. WLA $=78 \%$ reduction from base conditions. Base conditions were approximated as the mean loading without BMPs. 
City of Portland

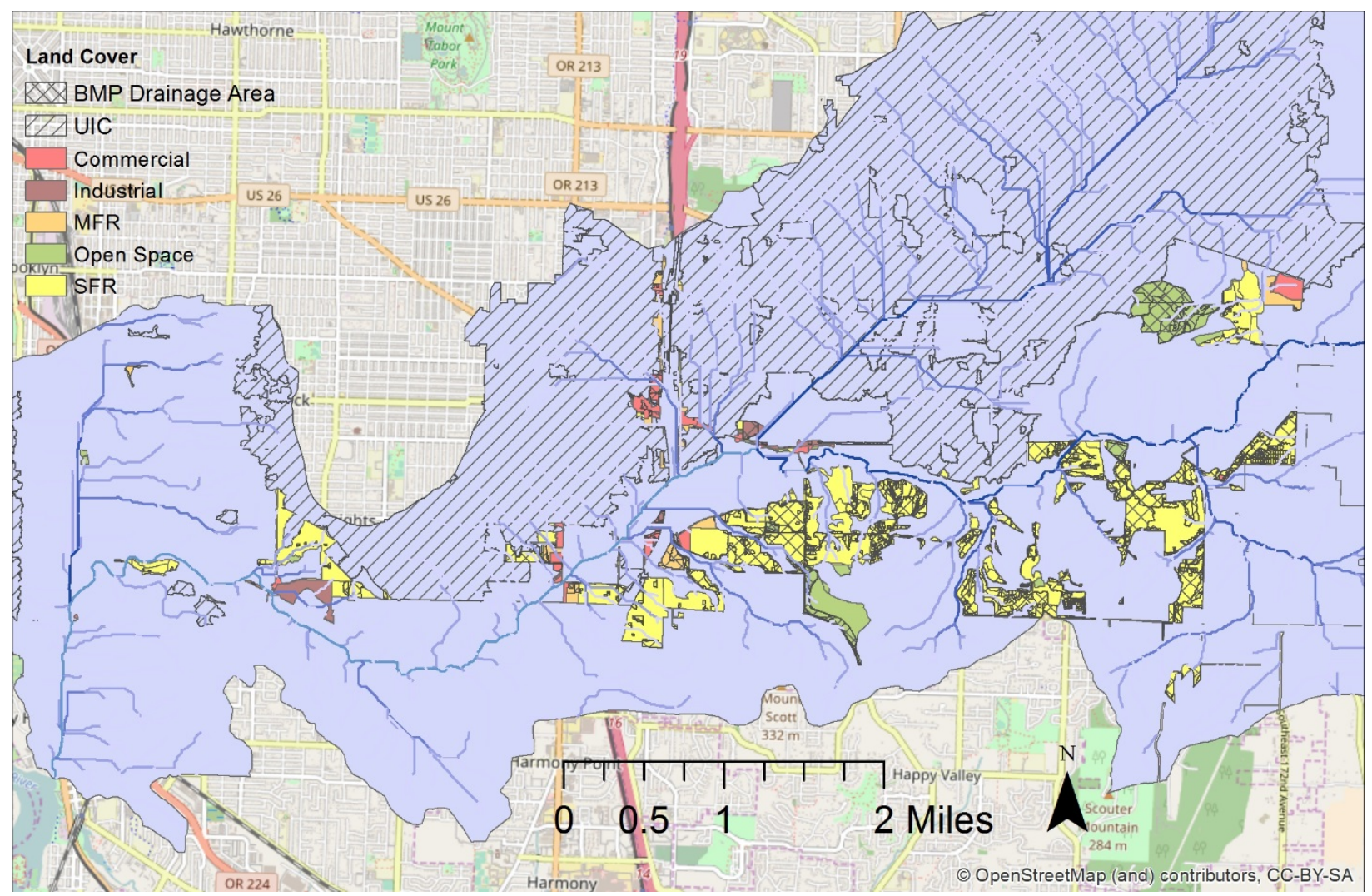

Figure 32. Map of zoning categories and treated areas for Portland MS4 boundary within Johnson Creek.

Table 40. COP MS4 area impervious surface percentages and runoff coefficients by land use for estimating 2015 bacterial loading. Land use/ Land cover data presented is from 2015.

\begin{tabular}{|c|c|c|c|c|c|}
\hline $\begin{array}{c}\text { Land Use } \\
\text { Category }\end{array}$ & Impervious \% & $\begin{array}{c}\text { Runoff } \\
\text { Coefficient }\end{array}$ & $\begin{array}{c}\text { Total Area } \\
\text { (Acres) }\end{array}$ & $\begin{array}{c}\text { Treated Area } \\
\text { (Acres) }\end{array}$ & $\begin{array}{c}\text { Annual } \\
\text { Precipitation } \\
\text { (in/yr) }\end{array}$ \\
\hline Industrial & 77.09 & 0.744 & 51 & 10 & 47 \\
\hline Open Space & 8.79 & 0.129 & 180 & 135 & 48 \\
\hline Commercial & 75.27 & 0.727 & 77 & 17 & 48 \\
\hline Residential & 37.23 & 0.385 & 1012 & 590 & 50 \\
\hline $\begin{array}{c}\text { Multi Family } \\
\text { Res }\end{array}$ & 51.31 & 0.512 & 76 & 20 & 47 \\
\hline
\end{tabular}

1. Runoff Coefficient is calculated from the EPA equation: $\mathrm{C}=0.05+0.009$ (\% impervious) 
Table 41. Land use event mean storm concentrations (EMCs) of E. coli utilized by all Oregon Association of Clean Water Agencies (ACWA) which includes the following DMAs within the Johnson Creek watershed: Portland, Gresham, Milwaukie, and Happy Valley.

\begin{tabular}{|l|c|c|c|c|}
\hline \multirow{3}{*}{ Pollutant } & \multirow{2}{*}{ Land Use } & \multicolumn{3}{|c|}{ Land Use EMCs } \\
\cline { 3 - 5 } & $\begin{array}{c}\text { 95\% Lower Conf } \\
\text { Interval }\end{array}$ & Geomean & $\begin{array}{c}\text { 95\% Upper Conf } \\
\text { Interval }\end{array}$ \\
\hline \multirow{4}{*}{ E. coli } & Agriculture & 573 & 1247 & 2409 \\
\cline { 2 - 5 } & Industrial & 154 & 438 & 1004 \\
\cline { 2 - 5 } & Open Space & 57 & 87 & 124 \\
\cline { 2 - 5 } & Undeveloped & 57 & 87 & 124 \\
\cline { 2 - 5 } & Commercial & 573 & 1247 & 2409 \\
\cline { 2 - 5 } & Residential & 970 & 1656 & 2651 \\
\cline { 2 - 5 } & Multi Family Res & 970 & 1656 & \\
\hline
\end{tabular}

Table 42. COP 2015 bacterial loading with and without BMPs and the associated \% load reduction from implementation of BMPs.

\begin{tabular}{|c|c|c|c|c|c|c|c|c|}
\hline \multirow{3}{*}{$\begin{array}{l}\text { Land Use } \\
\text { Category }\end{array}$} & \multicolumn{6}{|c|}{$\begin{array}{l}2015 \text { Bacterial Loading } \\
\text { (Colonies/Year) }\end{array}$} & \multirow{3}{*}{$\begin{array}{l}\text { WLA } \\
\text { Mean }\end{array}$} & \multirow{3}{*}{$\begin{array}{c}\begin{array}{c}\text { BMP } \\
\text { Load } \\
\text { Reduction } \\
(\%)\end{array} \\
\begin{array}{c}\text { WLA }=78 \% \\
\text { Reduction }\end{array} \\
\end{array}$} \\
\hline & \multicolumn{3}{|c|}{ Without BMPs } & \multicolumn{3}{|c|}{ With BMPs } & & \\
\hline & LCI $^{1}$ & Mean & $\mathbf{U C I}^{2}$ & LCI $^{1}$ & Mean & $\mathbf{U C I}^{2}$ & & \\
\hline Industrial & $2.5 \mathrm{E}+11$ & $7.2 \mathrm{E}+11$ & $1.7 \mathrm{E}+12$ & $2.4 \mathrm{E}+11$ & $6.6 \mathrm{E}+11$ & $1.5 \mathrm{E}+12$ & $1.6 \mathrm{E}+11$ & $8 \%$ \\
\hline Open Space & $5.8 \mathrm{E}+10$ & $8.9 E+10$ & $1.3 \mathrm{E}+11$ & $4.3 \mathrm{E}+10$ & $6.6 \mathrm{E}+10$ & $9.4 \mathrm{E}+10$ & $2.0 \mathrm{E}+10$ & $26 \%$ \\
\hline Commercial & $1.3 \mathrm{E}+12$ & $3.0 \mathrm{E}+12$ & $5.9 \mathrm{E}+12$ & $1.2 \mathrm{E}+12$ & $2.8 \mathrm{E}+12$ & $5.3 \mathrm{E}+12$ & $6.6 \mathrm{E}+11$ & $8 \%$ \\
\hline Residential & $1.7 \mathrm{E}+13$ & $3.0 \mathrm{E}+13$ & $4.7 \mathrm{E}+13$ & $1.4 \mathrm{E}+13$ & $2.3 \mathrm{E}+13$ & $3.3 \mathrm{E}+13$ & $6.6 \mathrm{E}+12$ & $23 \%$ \\
\hline $\begin{array}{c}\text { Multi Family } \\
\text { Res }\end{array}$ & $1.6 \mathrm{E}+12$ & $2.8 \mathrm{E}+12$ & $4.4 \mathrm{E}+12$ & $1.5 \mathrm{E}+12$ & $2.5 \mathrm{E}+12$ & $3.8 \mathrm{E}+12$ & $6.2 \mathrm{E}+11$ & $11 \%$ \\
\hline Total & $2.0 \mathrm{E}+13$ & $3.7 E+13$ & $5.9 \mathrm{E}+13$ & $1.8 \mathrm{E}+13$ & $2.7 E+13$ & $4.4 \mathrm{E}+13$ & $8.1 \mathrm{E}+12$ & $27 \%$ \\
\hline
\end{tabular}

1. LCI $=$ lower value of $95 \%$ confidence interval for land use based stormwater runoff concentrations

2. $\quad$ UCI =upper value of 95\% confidence interval for land use based stormwater runoff concentrations

3. WLA $=78 \%$ reduction from base conditions. Base conditions were approximated as the mean loading without BMPs. 
City of Milwaukie

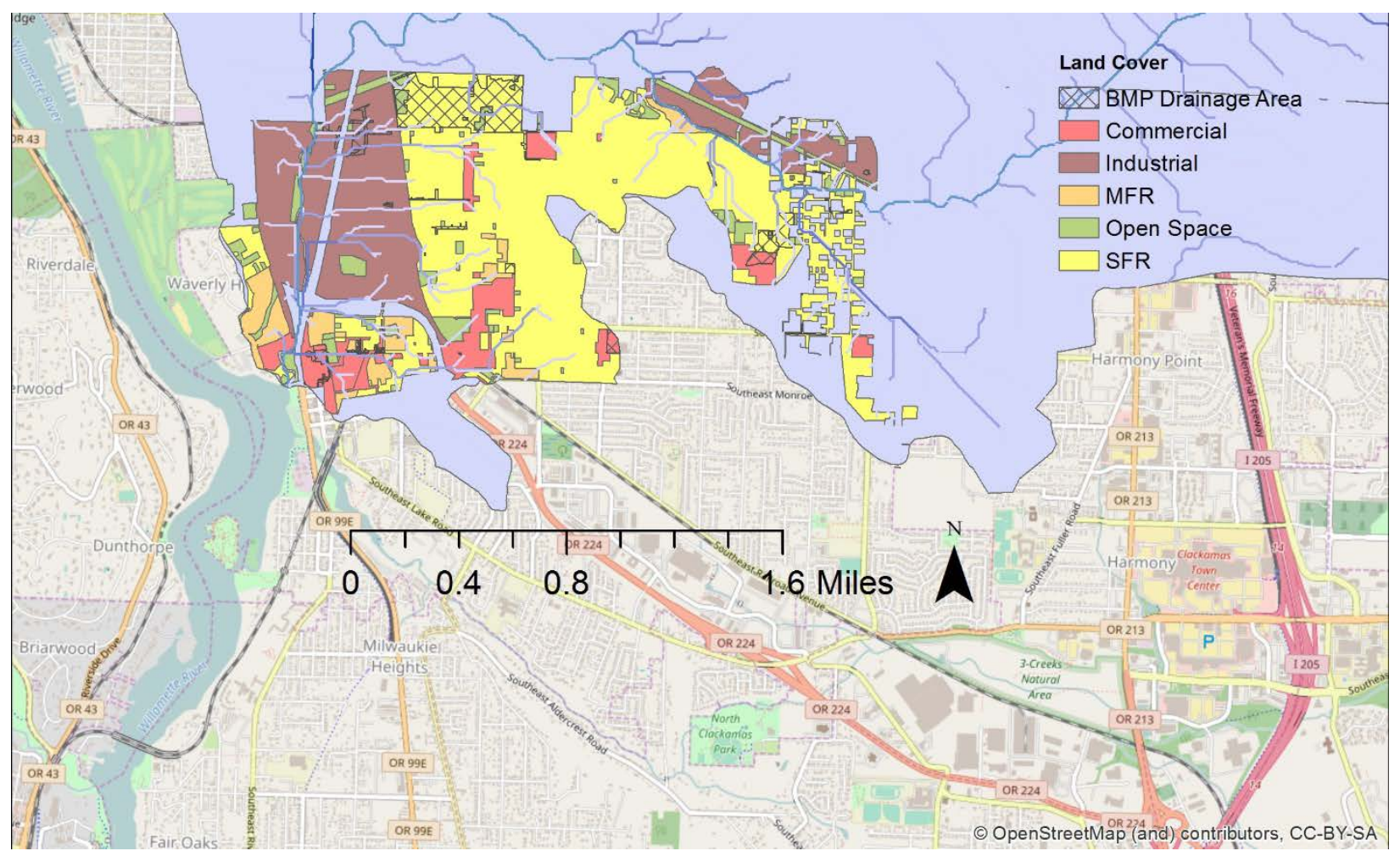

Figure 33. Map of zoning categories and treated areas for Milwaukie MS4 boundary within Johnson Creek.

Table 43. COM Impervious surface percentages and runoff coefficients by land use for estimating 2015 bacterial loading. Land use/ Land cover data presented is from 2016.

\begin{tabular}{|c|c|c|c|c|c|}
\hline $\begin{array}{l}\text { Land Use } \\
\text { Category }\end{array}$ & $\begin{array}{c}\text { Impervious } \\
\%\end{array}$ & $\begin{array}{c}\text { Runoff } \\
\text { Coefficient }\end{array}$ & $\begin{array}{l}\text { Total Area } \\
\text { (Acres) }\end{array}$ & $\begin{array}{l}\text { Treated Area } \\
\text { (Acres) }\end{array}$ & $\begin{array}{c}\text { Annual } \\
\text { Precipitation (in/yr) }\end{array}$ \\
\hline Industrial & 79 & 0.76 & 296 & 6 & 46.20 \\
\hline Open Space & 40 & 0.41 & 27 & 3 & 46.22 \\
\hline Vacant $^{2}$ & 27 & 0.29 & 53 & 4 & 46.22 \\
\hline $\begin{array}{l}\text { Public } \\
\text { Facility }^{2}\end{array}$ & 47 & 0.48 & 25 & 3 & 46.17 \\
\hline Commercial & 70 & 0.68 & 78 & 6 & 46.20 \\
\hline Residential & 44 & 0.45 & 625 & 60 & 46.24 \\
\hline $\begin{array}{c}\text { Multi Family } \\
\text { Res }\end{array}$ & 44 & 0.45 & 59 & $\sim 0$ & 46.17 \\
\hline
\end{tabular}

1. Runoff Coefficient is calculated from the EPA equation: $\mathrm{C}=0.05+0.009$ (\% impervious)

2. EMC values for vacant and public facility zones were modeled under ACWA categories commercial and open space respectively. 
Table 44. COM 2015 bacterial loading with and without BMPs and the associated \% load reduction from implementation of BMPs.

\begin{tabular}{|c|c|c|c|c|c|c|c|c|}
\hline \multirow{3}{*}{$\begin{array}{l}\text { Land Use } \\
\text { Category }\end{array}$} & \multicolumn{6}{|c|}{$\begin{array}{c}2015 \text { Bacterial Loading } \\
\text { (Colonies/Year) }\end{array}$} & \multirow{3}{*}{$\begin{array}{c}\text { WLA } \\
\text { Mean }\end{array}$} & \multirow{3}{*}{$\begin{array}{c}\text { BMP } \\
\text { Load } \\
\text { Reduction } \\
W L A=78 \% \\
\text { Reduction }\end{array}$} \\
\hline & \multicolumn{3}{|c|}{ Without BMPs } & \multicolumn{3}{|c|}{ With BMPs } & & \\
\hline & $\mathbf{L C I}^{1}$ & Mean & $\mathbf{U C I}^{2}$ & $\mathrm{LCI}^{1}$ & Mean & $\mathbf{U C I}^{2}$ & & \\
\hline Industrial & $1.5 \mathrm{E}+12$ & $4.2 \mathrm{E}+12$ & $9.7 \mathrm{E}+12$ & $\sim 1.5 \mathrm{E}+12$ & $\sim 4.2 \mathrm{E}+12$ & $9.6 \mathrm{E}+12$ & $9.2 \mathrm{E}+11$ & $\sim 0 \%$ \\
\hline Open Space & $2.7 \mathrm{E}+10$ & $4.1 \mathrm{E}+10$ & $5.9 \mathrm{E}+10$ & $2.6 \mathrm{E}+10$ & $4.0 \mathrm{E}+10$ & $5.7 \mathrm{E}+10$ & $9.0 \mathrm{E}+09$ & $3 \%$ \\
\hline Vacant & $3.7 \mathrm{E}+10$ & $5.7 \mathrm{E}+10$ & $8.2 \mathrm{E}+10$ & 3.7E+10 & $5.6 \mathrm{E}+10$ & $8.0 \mathrm{E}+10$ & $1.3 \mathrm{E}+10$ & $2 \%$ \\
\hline $\begin{array}{l}\text { Public } \\
\text { Facility }\end{array}$ & $2.9 \mathrm{E}+11$ & $6.4 \mathrm{E}+11$ & $1.2 \mathrm{E}+12$ & $\sim 2.9 \mathrm{E}+11$ & $6.3 E+11$ & $\sim 1.2 \mathrm{E}+12$ & $1.4 \mathrm{E}+11$ & $2 \%$ \\
\hline Commercial & $1.3 \mathrm{E}+12$ & $2.8 \mathrm{E}+12$ & $5.8 \mathrm{E}+12$ & $1.2 \mathrm{E}+12$ & $2.7 \mathrm{E}+12$ & $5.1 \mathrm{E}+12$ & $6.2 \mathrm{E}+11$ & $4 \%$ \\
\hline Residential & $1.2 \mathrm{E}+13$ & $2.0 \mathrm{E}+13$ & $3.2 \mathrm{E}+13$ & $1.1 \mathrm{E}+13$ & $1.9 \mathrm{E}+13$ & $3.1 \mathrm{E}+13$ & $4.4 \mathrm{E}+12$ & $5 \%$ \\
\hline $\begin{array}{l}\text { Multi Family } \\
\text { Res }\end{array}$ & $1.1 \mathrm{E}+12$ & $1.9 \mathrm{E}+12$ & $3.0 \mathrm{E}+12$ & $\sim 1.1 \mathrm{E}+12$ & 1.9E+12 & $3.0 \mathrm{E}+12$ & $4.2 \mathrm{E}+11$ & $0 \%$ \\
\hline Total & $1.6 \mathrm{E}+13$ & $3.0 \mathrm{E}+13$ & $5.1 \mathrm{E}+13$ & $1.6 \mathrm{E}+13$ & $2.9 \mathrm{E}+13$ & $5.0 \mathrm{E}+13$ & $6.5 \mathrm{E}+12$ & $3 \%$ \\
\hline
\end{tabular}

1. LCI $=$ lower value of $95 \%$ confidence interval for land use based stormwater runoff concentrations

2. $\quad$ UCI =upper value of 95\% confidence interval for land use based stormwater runoff concentrations

3. WLA $=78 \%$ reduction from base conditions. Base conditions were approximated as the mean loading without BMPs. 


\section{Clackamas County Service District \#1}

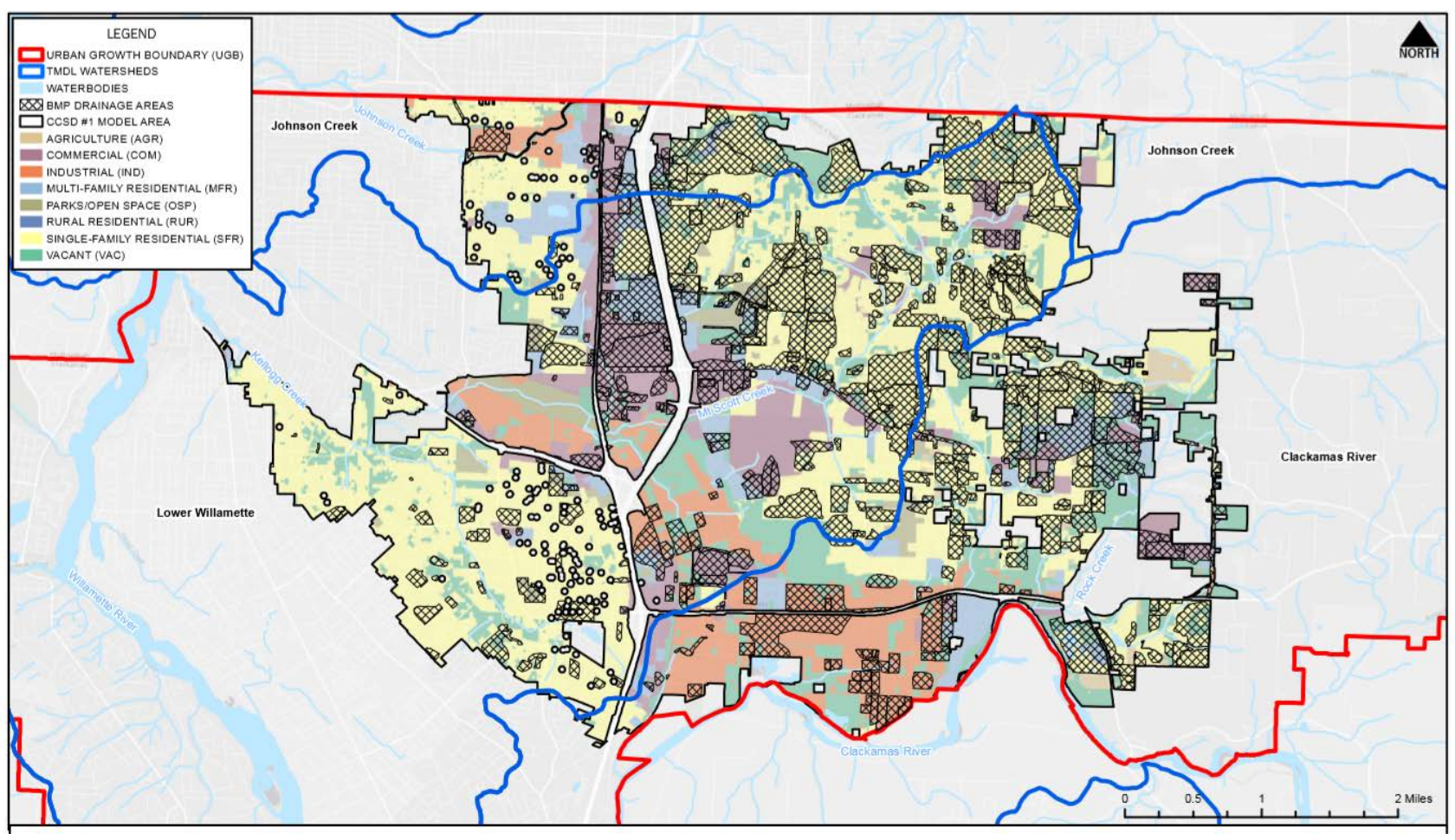

Figure 34. Map of zoning categories and treated areas for CCSD\#1 MS4 boundary within Johnson Creek (WES 2015)

Table 45. Happy Valley Impervious surface percentages and runoff coefficients by land use for estimating 2015 bacterial loading. Land use/ Land cover data presented is from 2016.

\begin{tabular}{|c|c|c|c|}
\hline $\begin{array}{c}\text { Land Use } \\
\text { Category }\end{array}$ & Impervious \% & Total Area (Acres) & Annual Precipitation (in/yr) \\
\hline Industrial & 6 & 108 & 40 \\
\hline Residential & 42 & 826 & 40 \\
40 \\
\hline $\begin{array}{c}\text { Multi-Family } \\
\text { Residential }\end{array}$ & 61 & 190 & 40 \\
\hline Agriculture & 5 & $\sim 0$ & 40 \\
\hline Vacant & 5 & 218 & 40 \\
\hline $\begin{array}{c}\text { Parks/Open } \\
\text { Space }\end{array}$ & 7 & 6 & 40 \\
\hline \begin{tabular}{c} 
Commercial \\
\hline
\end{tabular} & 72 & 131 & 40 \\
\hline
\end{tabular}


Table 46. CCSD\#1 2015 bacterial loading with and without BMPs and the associated \% load reduction from implementation of BMPs.

\begin{tabular}{|c|c|c|c|c|c|c|c|c|}
\hline \multirow{3}{*}{$\begin{array}{l}\text { Land Use } \\
\text { Category }\end{array}$} & \multicolumn{6}{|c|}{$\begin{array}{c}2015 \text { Bacterial Loading } \\
\text { (Colonies/Year) }\end{array}$} & \multirow[t]{2}{*}{ WLA } & \multirow{2}{*}{$\begin{array}{c}\text { BMP } \\
\text { Load } \\
\text { Reduction } \\
\text { (\%) } \\
\text { WLA }=78 \% \\
\text { Reduction } \\
\end{array}$} \\
\hline & \multicolumn{3}{|c|}{ Without BMPs } & \multicolumn{3}{|c|}{ With BMPs } & & \\
\hline & $\mathrm{LCI}^{1}$ & Mean & $\mathbf{U C I}^{2}$ & $\mathrm{LCI}^{1}$ & Mean & $\mathbf{U C I}^{2}$ & Mean & \\
\hline Total & $1.9 \mathrm{E}+13$ & $3.4 \mathrm{E}+13$ & $5.7 \mathrm{E}+13$ & $1.8 \mathrm{E}+13$ & $3.2 \mathrm{E}+13$ & $5.1 \mathrm{E}+13$ & $7.5 \mathrm{E}+12$ & $6.2 \%$ \\
\hline
\end{tabular}

1. LCI = lower value of $95 \%$ confidence interval for land use based stormwater runoff concentrations

2. $\quad$ UCI =upper value of 95\% confidence interval for land use based stormwater runoff concentrations

3. WLA $=78 \%$ reduction from base conditions. Base conditions were approximated as the mean loading without BMPs.

4. Results from (Water Environment Services, 2015) 
Results

Evaluation of overall load reductions for each of the 4 MS4 agencies within the watershed: Gresham, Portland, CCSD\#1, and Milwaukie, showed that none of the agencies were close to meeting the $78 \%$ reduction. Portland had the highest reduction from structural BMPs (27\%) (Table 42), while the other agencies showed reductions between 3-6\% (Table 39, Table 44, Table 46). Residential land use contributed to nearly all of the E. coli loading for both City of Portland and Milwaukie (Table 42) and (Table 44), while both residential and commercial land use were major contributors of E. coli loading in Gresham (Table 39). Analysis was conducted by each of the agencies to test the feasibility of meeting the 78\% reduction target. Each of the agencies determined that even with the most effective treatment technology (filter strips) covering the entirety of the MS4, the 78\% reduction target could not be met (City of Gresham, 2014), (City of Portland, 2014), (WES, 2015), and (City of Milwaukie, 2016). 


\section{Discussion}

In examining Johnson Creek over the past 20 years, I found declines in E. coli concentrations and loads at two out of the four study sites assessed. Determining the major sources of bacteria and effectiveness of management actions proved extremely difficult because of insufficient data. Inconsistent temporal spacing and sparse data rendered trend analyses largely un-interpretable. My analysis of TMDL implementation activities, while showing much has been done to address bacteria in the Johnson Creek watershed, nonetheless remains inconclusive as to whether or not activities are having desired effects on bacteria loading.

Despite the difficulties associated with determining major sources of E. coli loading and the effectiveness of management actions, the use of a spatial framework to organize the findings in this study proved to be useful in synthesizing probable answers to these major questions based off of currently available data. The spatial framework that will be used to facilitate this discussion consists of incremental subwatershed regions for each of the four study sites (Figure 35). An incremental subwatershed consists of the non-overlapping portion between two adjacent subwatersheds. These incremental subwatersheds will be used to represent bacterial source areas unique to each study site, and will simply be referred to as subwatersheds for the remainder of the discussion. It is important to note that the subwatershed regions that will be discussed do not coincide with jurisdictional boundaries in the watershed, as such there may be several DMAs for a given subwatershed. By integrating and evaluating land use characteristics (Figure 2),

precipitation trends over time, the relationship between E. coli and precipitation, and the status of E. coli loading (following TMDL actions) for each of the subwatershed regions, potential sources of $E$. coli may be better understood. Changes in loading described herein after will refer to loading conditions following implementation of TMDL actions. 


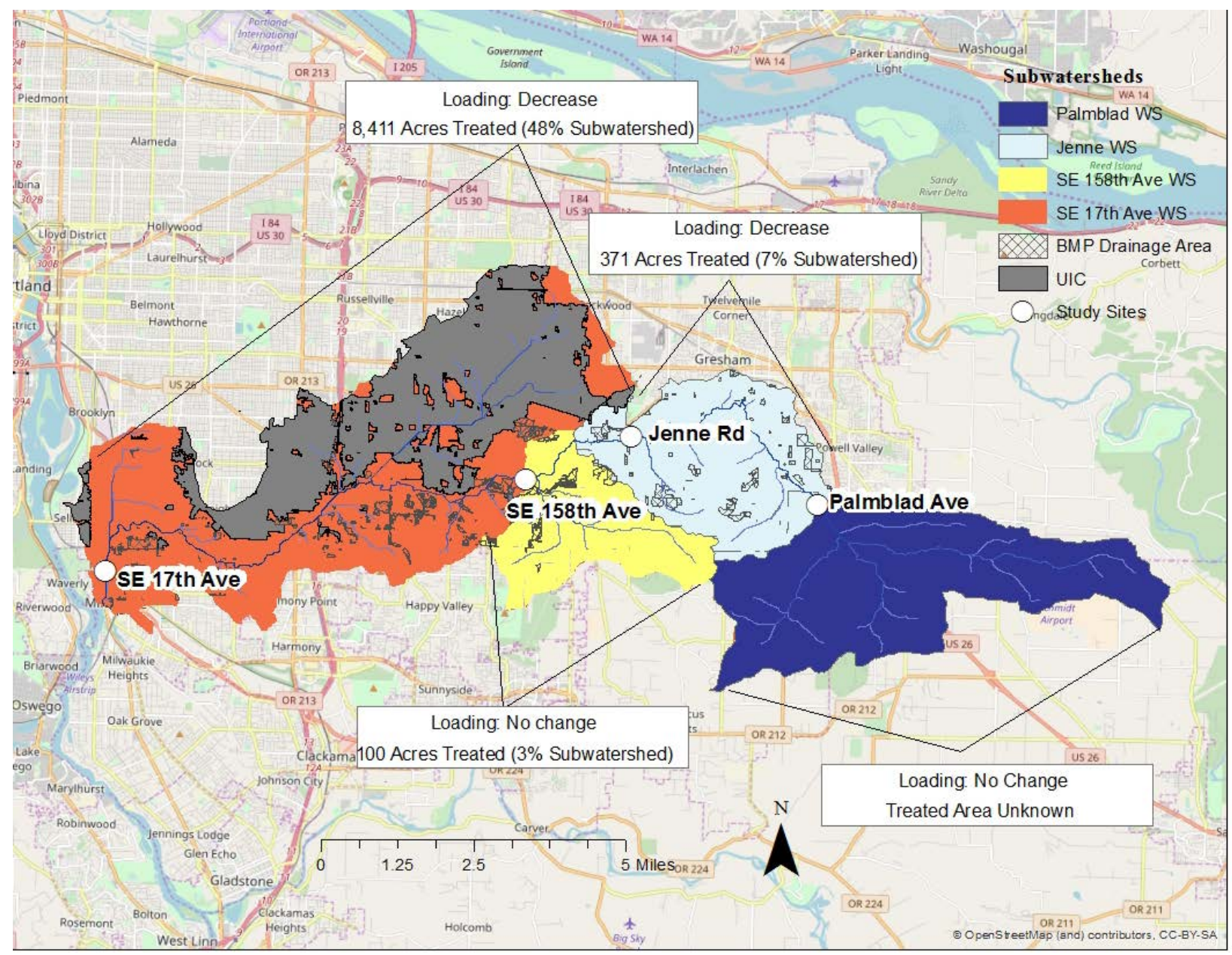

Figure 35. Incremental watershed regions for each of the four study sites including treated areas (MS4 only, includes UIC) and overall changes (126 cfu/ $100 \mathrm{~mL}$ standard) in loading following the implementation of TMDL actions.

The lack of any appreciable improvements in loading conditions at Palmblad Ave (Figure 35, Table 28, and Table 29) for all flow regimes other than typical flows, both before and after TMDL actions, suggests that there are numerous sources responsible for bacterial water quality impairments and that management actions do not appear to be effectively targeting these sources. Sources of E. coli loading for Palmblad subwatershed are likely related to rural and agricultural land use which accounts for $79 \%$ of the subwatershed (5,468 acres). The remaining $21 \%$ of the 
subwatershed is $(1,717$ acres) consists of forested lands which are not assumed to be a major source of E. coli loading due to low impervious coverage and compliance with the Forest Practices Act (Figure 2). Potential sources of E. coli during wet weather includes runoff from manure piles, which may be from CAFOs (2 out of 4 CAFOs in Johnson Creek are within Palmblad subwatershed), smaller livestock operations, and/or hobby farms (ODEQ, 2006). Of the sources mentioned, CAFOs operate under an NPDES permit and are not allowed to discharge any waste to the stream with the exception of a one-in-five, or one-in-ten year, 24 hour storm event from November 1 to May 21, or from May 22 to October 31 respectively (ODEQ, 2006). Therefore, with the exception of high magnitude storm events, CAFOs are not anticipated to be a major source of E. coli loading.

Counter to what was initially hypothesized, Palmblad exhibited a stronger log-linear relationship between $E$. coli and precipitation than any of the other study sites. This however, makes sense as Palmblad subwatershed has impermeable soils and more uniform land use characteristics (rural/agricultural) than the predominately urbanized portions of the watershed, which each contain several different types of land uses with differing values of percent impervious surfaces. Therefore, runoff events in the Palmblad subwatershed can be expected to be more directly responsive to precipitation events. The occurrence of runoff events for Palmblad subwatershed is supported by the study of Lee and Snyder (2009) which states that drains, ditches, and silt loam soils in the upper portion of the Johnson Creek watershed results in high rates of runoff. Looking at the slopes of the high flow end of the Load Duration Curves for Palmblad Ave before and after the TMDL (

Figure 23 and 
Figure 24) shows that the prevalence of runoff events does not appear to be changing despite increases in the magnitude of $90^{\text {th }}$ percentile precipitation events over time (1998-2016) (Figure 16 and Table 25). The lack of change and slight increases in loading for transitional and high flow regimes respectively, coupled with increases in the magnitude of $90^{\text {th }}$ percentile precipitation events at Palmblad Ave may indicate that volume reduction type structural BMPs are offsetting increases in loading for all but the largest precipitation events (Table 28 and Table 29). Best management practices in Palmblad subwatershed generally are assistance projects funded by SWCDs and ODA to help landowners take precautionary actions to reduce runoff from manure piles; actions may include implementation of vegetative buffers, use of manure storage facilities and restoration activities to reduce erosion, and impervious surfaces (Table 24). Unfortunately, while ODA Biennial reports discuss projects occurring within Johnson Creek to prevent bacterial runoff, spatial and temporal data for installation of vegetative buffers and manure storage facilities within Palmblad subwatershed is unknown (Figure 35). Therefore, while it may be reasonable to assume that greater coverage of vegetative buffers or manure storage facilities may be needed in Palmblad subwatershed to prevent bacterial loading during storm events, no definitive conclusion can be made.

Major sources of E. coli loading occurring during dry weather conditions (low-typical flows) in the Palmblad subwatershed includes septic system failures, livestock and wildlife instream grazing, and birds. Major management actions taken by Multnomah County, Clackamas County, and ODA respectively, to address these sources includes educating homeowners regarding proper septic system maintenance, decommissioning and replacing failed septic systems, hooking properties up to the municipal sanitary sewer system if available, and livestock exclusion from the stream by fencing off riparian areas (Table 13,Table 14, Table 21 and Table 24). 
Substantial improvement in loading conditions were found for typical flows but not dry or low flows. Because instream grazing by livestock is less likely to occur during typical flows, than dry or low flow conditions, the improvements in E. coli loading conditions during typical flows may be related to the replacement of failing septic systems; unfortunately, data regarding number and location of septic systems in the watershed before and after the TMDL was not available for this report, and as such the claim that replacement of septic systems may be responsible for improvements in typical flow loading conditions at Palmblad Ave is only speculation.

Conversely, the lack of change in loading conditions for dry and low flows at Palmblad Ave may be attributed to livestock or wildlife instream grazing. Similar to septic systems however, management actions to address livestock grazing are difficult to assess as there is currently no spatial inventory of livestock exclusion areas in the watershed.

Unlike the Palmblad subwatershed, the Jenne subwatershed is dominated by urban land uses (Figure 2 and Figure 35). Both City of Gresham and Multnomah County are the agencies responsible for implementing BMPs within the Jenne subwatershed. Point source bacterial loading in the Jenne subwatershed is addressed by City of Gresham as a condition of their NPDES permit for the City's MS4 region. Nonpoint bacterial loading sources such as septic systems, on the other hand, are the primary responsibility of Multnomah County, but are typically addressed by the City of Gresham in coordination with the County. Substantial improvements in bacterial water quality over the last two decades (1999-2016) for Jenne Rd observed from both loading analysis (no change in loading during high flows) and bacterial trend analysis (Figure 13), suggest that management actions from both MS4 and TMDL programs may be appropriately targeting sources of $E$. coli (Figure 25 and Figure 26). Sources of bacterial discharge to the stream occurring during wet weather conditions may include runoff from street, roofs, and 
curbs into the MS4 system, or by surface water runoff. Sources of waste transported by runoff may include pets, homeless encampments (Jenne Rd is near the Springwater Corridor), birds, and wildlife. By contrast, sources of E. coli loading occurring during dry weather conditions in Jenne subwatershed may include septic system discharge, sanitary system failures, cross connections between storm and sanitary sewer systems, and potentially direct input from homeless encampments.

Declines in E. coli loading in Jenne subwatershed during transitional flows is most likely attributed to treatment and or/ volume reduction from green infrastructure facilities coupled with no significant changes in either $90^{\text {th }}$ or $100^{\text {th }}$ percentile precipitation events (Figure 17) over the last two decades (1998-2016). Approximately 371 acres (7\% subwatershed) within the Jenne watershed are treated by structural BMPs. Despite the low coverage of areas treated by structural BMPs within the Jenne subwatershed, approximately 23\% (1,233 acres) of the Jenne subwatershed consists of natural areas (Figure 31 and Figure 35). While natural areas may contribute bacterial loading to the stream through instream grazing by wildlife during dry weather conditions, during wet weather conditions they are not a likely source of bacterial loading due to low impervious coverage, and are therefore, considered as self-treated areas (City of Gresham, 2014). Therefore, approximately $70 \%$ of Jenne subwatershed may be considered as untreated source areas. While it is known that structural BMPs have been constructed within the City of Gresham MS4 area (including Jenne subwatershed) since the adoption of the TMDL (Table 36), the exact coverage of BMPs installed following the TMDL is unclear due to insufficient data regarding installation dates.

Comparing bacterial water quality of Jenne Rd to Palmblad Ave during wet weather conditions ideally would provide insights regarding relative importance of upstream vs. adjacent 
E. coli source areas. A qualitative assessment of relative E. coli loading contributions from adjacent and upstream areas however, proved to be a difficult task. Loading at Palmblad Ave during high and transitional flows showed a slight increase and no change respectively (Table 28 and Table 29), while loading at Jenne Rd was shown to not change for high flows and to slightly decrease for transitional flows (Table 30 and Table 31). These findings could indicate that loading from Palmblad subwatershed is quickly transported downstream during high and transitional flows and therefore, is not registered during sampling at Jenne Rd (Figure 35). The contribution of E. coli loading from adjacent land uses to Jenne Rd. similar to upstream sources, could not be assessed. The statistically significant but weak, log-linear relationship between E. coli and precipitation at Jenne Rd, indicates that runoff of E. coli is likely occurring, but that numerous land uses within the Jenne subwatershed (Figure 31 and Figure 35) may require more variables than just precipitation to more appropriately predict $E$. coli concentrations. A lack of insight regarding source areas is in part due to samples between Palmblad Ave and Jenne Rd never being collected on the same day. Further, in order to gather a better understanding of the nature of $E$. coli sources (human/animal) and better isolate source regions, it is vital to have bacterial source tracking studies. While a bacterial source tracking study is available for Jenne Rd (and sites near SE $17^{\text {th }}$ Ave) for the dry season (Jenkinson et al. 2014), there is no source tracking study available for the wet season in Johnson Creek.

With regards to decreases in loading during dry weather conditions (dry and low flows), management actions related to removing septic systems and connecting residents to the sanitary sewer line would likely be the most relevant management actions to attribute the decreases for these flow regimes. As shown, (Table 19) Gresham made 393 connections to the sanitary system from 2009-2016 and replaced (with new septic system) or connected 10 residents to the sanitary 
system for the same time period. Although no source tracking studies are available prior to TMDL implementation, a bacterial source tracking study conducted in Johnson Creek during the dry season, found that bacterial samples collected near Jenne Rd (Butler Creek @ SW 14 ${ }^{\text {th }}$ ) were most likely from human sources (Jenkinson et al. 2014). This finding supports the conclusion that septic system removal may be responsible for improvements in water quality during dry, and low flow regimes at Jenne Rd. Unfortunately, septic system replacements are reported on a city-wide basis; therefore, it is difficult to correlate improvements in water quality to the reported number of septic system replacements as they may or may not be occurring within the watershed.

Further, although not captured in the data presented in this study, in 2016 City of Gresham began conducting cleanups of human waste and clearing up homeless encampments within the Spring Water Corridor. This can be expected to have positive impacts on water quality in the future (Table 18).

Land coverage within the SE $158^{\text {th }}$ subwatershed, similar to the Palmblad subwatershed, consists of rural/agricultural and forested land uses. Numerous jurisdictional boundaries are contained within the SE $158^{\text {th }}$ subwatershed including: City of Gresham, Multnomah County, Clackamas County, and CCSD \#1/ Happy Valley. Pollutant discharges to the MS4 system in the SE $158^{\text {th }}$ subwatershed are addressed by City of Gresham, CCSD \#1/ Happy Valley, and to a small extent by Multnomah County. Nonpoint discharges to Johnson Creek within the SE $158^{\text {th }}$ subwatershed by contrast, are addressed by City of Gresham, Multnomah County, and Clackamas County. Major potential sources of $E$. coli loading to the stream during wet weather conditions for SE $158^{\text {th }}$ subwatershed includes runoff discharging to either MS4 systems or directly into the stream as overland flow. Potential sources of $E$. coli related to runoff events in 
SE $158^{\text {th }}$ subwatershed includes homeless encampments (Jenkinson et al., 2014), CAFOs (2 out of 4 CAFOs in Johnson Creek are in the SE $158^{\text {th }}$ subwatershed), smaller livestock operations, and pets (ODEQ, 2006). As previously mentioned, CAFOs are not assumed to be a major source of $E$. coli loading as they are not allowed to discharge any waste to the stream under their NPDES permits with the exception of a one-in-five, or one-in-ten year, 24 hour storm event from November 1 to May 21, or from May 22 to October 31 respectively (ODEQ, 2006).

Although spatial data needed to delineate all MS4 boundaries within the SE $158^{\text {th }}$ subwatershed was not obtained for this report, visual inspection of approximate MS4 boundaries (Figure 7, Figure 31,Figure 34 andFigure 35) indicates that the coverage of MS4s is not substantial. As shown in (Figure 2), the stream network within the SE $158^{\text {th }}$ subwatershed (Figure 35) is almost entirely bordered by agricultural land, as a result runoff is most likely dominated by overland flow within this area. The lack of a significant relationship between $E$. coli and precipitation for SE $158^{\text {th }}$ Ave, is a peculiar finding as soils within the SE portion of Johnson Creek have been found to exhibit high runoff potential (BES, 2005). The lack of a log-linear relationship between E. coli and precipitation however, does not mean that runoff is not occurring, rather it indicates that runoff alone is not the only major source of $E$. coli for the subwatershed region. Negligible and minor improvements in loading for high and transitional flows respectively, may potentially be the result of a lag time for management actions to begin to have a noticeable effect on water quality (Meals et al, 2009); conversely, not enough structural BMPs may have been installed. Because no statistically significant change in $90^{\text {th }}$ and $100^{\text {th }}$ percentile precipitation trends (Table 26) were observed over time (1998-2016), it is not likely that an increase in runoff is occurring to counter progress attributed to management actions. Whether or not the relatively stagnant loading conditions for high and transitional flows within the SE $158^{\text {th }}$ subwatershed are attributed 
to insufficient management actions cannot be properly assessed in this paper for several reasons: structural BMP spatial data is only available for MS4s, installation dates for structural BMPs have numerous data gaps-preventing evaluation of progress over time, and because nonequivalent sampling dates between study sites prevents comparison of water quality between subwatershed regions.

E. coli loading changes for dry weather conditions (typical, dry, and low flows) at SE $158^{\text {th }}$ subwatershed, much like during wet weather conditions were difficult to correlate to management actions. Major potential sources of $E$. coli loading occurring during dry weather conditions in SE $158^{\text {th }}$ subwatershed includes septic systems, livestock/wildlife instream grazing, and homeless encampments. Increases in loading during typical flows were likely the result of septic system discharge as high concentrations of E. coli were observed during periods of no precipitation. Using concentrations as a proxy for potential sources however, can be misleading as a bacterial source tracking study by Whitlock et al. (2002) found that E.coli sources from dogs and wildlife alone could result in concentrations as high as 11,300 cfu/100 mL. Conversely, moderate and substantial improvements in loading conditions during dry and low flows respectively, may be attributed to livestock exclusion from riparian areas. As mentioned previously however, spatial data for riparian fencing are currently unavailable, therefore, it cannot be determined to what extent this action is occurring and whether or not it is responsible for improvements in loading conditions.

SE $17^{\text {th }}$ Ave, the final site assessed in this study is located in Milwaukie near the mouth of the watershed, and is surrounded by industrial land use. Land use within the subwatershed is predominately urban within Portland and Milwaukie, and rural east of Milwaukie (Figure 2) and 
(Figure 35). In contrast to the other subwatershed regions, the SE $17^{\text {th }}$ Ave subwatershed contains extensive UIC coverage (Figure 35). Approximately 48\% (8,411 acres) of the SE $17^{\text {th }}$ Ave subwatershed drains to surface water structural BMPs or UIC. Additionally, approximately 23\% (4,043 acres) of the subwatershed drains to an MS4 system. Pollutant discharges to MS4 systems within the SE $17^{\text {th }}$ Ave subwatershed are addressed by City of Portland, CCSD\#1, and City of Milwaukie. Nonpoint discharges to the stream on the other hand, are addressed by City of Portland, City of Milwaukie, Multnomah County, and Clackamas County. Sources of bacterial discharge to SE $17^{\text {th }}$ Ave occurring during wet weather conditions may include runoff from street, roofs, and curbs into the MS4 system, or by overland runoff from adjacent or upstream areas. Due to the high coverage of UIC areas and permeable soils within the northern portion of the subwatershed, runoff events impacting water quality in SE $17^{\text {th }}$ Ave subwatershed are likely mostly from upstream sources (Lee and Snyder, 2009) or from the southern portion of the subwatershed. Sources of waste transported by runoff may include pets, homeless encampments (SE Luther Rd and SE 45 ${ }^{\text {th }}$ Ave), birds, and wildlife. By contrast, sources of E. coli loading occurring during dry weather conditions in SE $17^{\text {th }}$ Ave subwatershed may include septic system discharge, sanitary system failures, cross connections between storm and sanitary sewer systems, and direct input from homeless encampments.

Minor improvements as well as setbacks in loading conditions for transitional and high flows respectively, were observed for SE $17^{\text {th }}$ Ave. This is an interesting finding, as a substantial portion of the subwatershed drains to structural BMPs. One explanation for this is that the capacity of stormwater holding facilities (detention and retention ponds) is being exceeded during high flow events. City of Gresham, City of Portland, and City of Milwaukie construct their storm detention and retention facilities to allow infiltration from $80^{\text {th }}, 90^{\text {th }}$, and $80^{\text {th }}$ 
percentile precipitation events respectively. Increases in both $90^{\text {th }}$ and $100^{\text {th }}$ percentile precipitation events over time near SE $17^{\text {th }}$ Ave (Figure 18) therefore, are likely the cause of worsening loading conditions for high flows. Conversely, substantial improvements in loading during dry weather conditions is likely attributed to a combination of activities including repairs made to the exposed Lents interceptor pipe in 2014 (located near Luther road within the Portland watershed boundary), removal of septic systems within both CCSD\#1 (Table 21), City of Gresham (Table 18), City of Milwaukie (Table 24), and Multnomah County (Table 14 and 15). Supporting rationale for this assumption is provided by a bacterial source tracking study in Johnson Creek by Jenkinson et al. (2014), which found strong indications of human related E.coli sources during the dry season from two sites within the Portland watershed boundary: SE $45^{\text {th }}$ Ave (homeless encampment), and SE Luther Road (septic and cess pools present).

Loading conditions and bacterial trends over time for SE $17^{\text {th }}$ Ave displayed many similarities to Jenne Rd: decreasing bacterial trend over time and a decrease in loading for all flow regimes other than high flows. Likewise, both SE $158^{\text {th }}$ Ave and Palmblad Ave displayed many similarities: relatively constant bacterial concentrations over time (no trend), and negligible changes in loading. Improvements in bacterial water quality for urbanized subwatersheds (Jenne Rd and SE $17^{\text {th }}$ Ave) and negligible changes in water quality for agricultural/rural subwatersheds (Palmblad Ave and SE $158^{\text {th }}$ Ave), may be evidence that a voluntary approach to managing agricultural lands is not the most effective approach. Although a voluntary approach to address nonpoint sources of pollution is heavily relied upon, on its own this approach may not be effective due to resistance to change by land owners and because of a lack of incentives offered, e.g. inadequate subsidies for control measures (Williams, 2002). A proactive approach by ODA, entailing periodic reviews of agricultural land use within the 
watershed, in addition to a voluntary based approach, would provide more incentive for homeowners to manage sources of E. coli loading (manure piles, in stream grazing by livestock) on their land.

Despite my attempt to define potential sources of E.coli loading to the stream, dominant sources are currently unknown for the wet season, and only limited information is available regarding human and wildlife sources for sites during the dry season. Further, the bacterial source tracking study that is available indicates the presence or absence of human or wildlife sources but does not quantify the influence of each, or provide an estimation of the source type (i.e septic systems, sanitary sewer discharge, livestock, instream grazing). This makes it difficult to assess how effective different BMPs have been and how well they have targeted sources of $E$. coli within the watershed. BMPs currently being implemented by DMAs address major potential sources of E. coli that occur during the wet season such as overland flow or discharges to the MS4, and sources that occur during the dry season including: failed septic and sanitary lines, illicit connections to the sanitary sewer system, and illicit discharges such as straight pipes and dumping of waste.

Practices implemented by DMAs to mitigate the impact of E.coli loading during high and transitional flow periods include replacement of impervious surfaces with low impact development technology to provide treatment and/ or volume reduction during storm events. Redeveloped areas for each of the cities within the watershed (Gresham, Portland, Milwaukie, and Happy Valley) currently require installation of low impact development technology to offset the impact of new impervious surfaces. Numerous revegetation activities additionally are being implemented by City of Gresham (Table 18), and City of Portland (Table 14 and Table 15). 
Although runoff sources are important to control, E. coli loading occurring during dry and low flow periods when contact recreation is more likely to occur and when loading capacity is low is arguably of greater concern. Both Clackamas County and Multnomah County coordinate with the cities (Gresham, Portland, and Milwaukie) to address septic and sanitary system failures and illicit connections through a combination of dry weather screening and responding to public complaints. Major efforts have been made by City of Gresham, CCSD\#1 and City of Milwaukie to extend the service boundary of sanitary sewer lines in order to remove septic systems from the watershed. Both Clackamas and Multnomah County require removal of septic systems and connection to sanitary sewer system in developed areas. Therefore, as the urban growth boundary expands and rural land uses begin to become developed, septic systems are anticipated to decline (City of Gresham, 2014) and (Water Environment Services, 2011).

DMAs within the watershed all participate in educational outreach activities to educate pet owners to properly discard of waste, and to educate septic system owners about proper maintenance. While these efforts are of value, they may not contribute significantly to E. coli loading reductions. A study by Gray et al. (2015) found that educational outreach activities may decrease E. coli loading by approximately 3.6-10.7\%. Furthermore, major source control BMPs conducted by each of the DMAs within the watershed including catch basin cleaning and street sweeping, while recognized as vital practices, are difficult to quantitatively assess. Lack of literature quantifying $E$. coli loading reductions attributed to source control practices made it impossible to incorporate these BMPs into benchmarking models; this therefore, made it difficult to gather a complete assessment regarding overall load reduction progress attributed to nonstructural as well as structural BMPs. 
Evaluation of overall load reductions for each of the four MS4 agencies within the watershed, Gresham, Portland, CCSD\#1, and Milwaukie, showed that none of the agencies were meeting the 78\% reduction. Portland had the highest reduction from structural BMPs (27\%), while the other agencies showed reductions of between 3-6\%. Analysis was conducted by each of the agencies to test the feasibility of meeting the $78 \%$ reduction target. Each of the agencies determined that even with the most effective treatment technology (filter strips) covering the entirety of the MS4, the 78\% reduction target could not be met (City of Gresham, 2014; City of Portland, 2014; Water Environment Services, 2015; and City of Milwaukie, 2016). These models however, may have limited practical use in making that determination as there are several drawbacks to their use including: static E. coli concentration values for a given land use, zoning categories may not represent actual land use, oversimplification of impervious surfaces, and difficulty attributing effect of BMPs in series. The overall findings of this study reveals that although required $E$. coli loading reductions are not currently being met that progress is slowly being met. 


\section{Future Recommendations}

In order to better assess progress towards meeting the TMDL and protecting water contact recreation, several factors should be considered in the future. These include sampling frequency, sampling coordination between DMAs, bacterial source tracking studies, reassessment of TMDL target based on flow regime, and record keeping of structural BMP installation locations and dates.

Sampling frequency for each of the four sites assessed in this study occurred at an insufficient frequency to measure the five sample $126 \mathrm{cfu} / 100 \mathrm{~mL}$ geometric mean standard. Within a 30 day period, none of the study sites ever met the 5 sample collection requirement. With the current update to the standard to require a $126 \mathrm{cfu} / 100 \mathrm{~mL}$ geometric mean from 5 samples collected within a 90 day period, this problem should be more reasonable to address. However, even with the 90 day collection period only Palmblad Ave met the 5 sample requirement on more than one occasion, but not consistently enough to make a meaningful assessment. Greater sampling frequency is not only important for assessing the $126 \mathrm{cfu} / 100 \mathrm{~mL}$ geometric mean standard, but for capturing representative E. coli concentrations throughout the year, and providing greater power to trend analysis. Ideally samples would be collected at a consistent frequency throughout the year, with an equal amount of samples between collection periods. This would allow standardized assessments of conditions over time without any bias to any particular sampling period.

Coordinated sampling events between DMAs would allow E. coli conditions to be assessed throughout the watershed for any given sampling period. Coordinated sampling efforts ideally would have E. coli samples collected in a succession from upstream to downstream sites. This 
would provide the information needed to determine for a given location in the watershed if loading is likely attributed to runoff (or direct inputs) from upstream areas or from adjacent land uses.

Additional bacterial source tracking studies would be helpful in coordinating management efforts. In particular, a study by Whittaker (2002) provided a way to determine loading contributions from human or wildlife sources using antibiotic resistance analysis. The assumption behind this analysis is that due to differential use of antibiotics between humans and wildlife there should be a readily distinguishable fingerprint available to determine the origin of bacteria samples. An advantage of using the antibiotic resistance analysis, or similar methods, is that total maximum daily loads for E. coli could be allocated to require reductions only from sources deemed to be of concern to human health; this would allow sources such as wildlife to be excluded if they are not deemed to be of any concern.

Furthermore, TMDL loading reductions (78\%) currently are based on an overall reduction target (average reduction over the entire load duration curve) rather than individual flow regime based loading reductions. Because load allocations are established to protect water contact recreation, which is a primary concern during dry and low flows, the current reduction target of 78\% may not be the most appropriate target. This is because higher flow regimes typically require greater reduction to meet the $126 \mathrm{cfu} / 100 \mathrm{~mL}$ standard (ODEQ, 2006 and EPA, 2007), and as a result this approach may be too conservative. Any future changes to the TMDL should consider adopting reduction targets based off flow regime, or potentially an overall reduction target based on dry and low flow conditions.

In order to document progress in water quality, a more thorough record of locations (nonMS4) and installation dates for structural BMPs will need to be maintained by DMAs. GIS data 
obtained for benchmark models, rarely documented the installation dates of BMPs. Similarly a lack of any available spatial data was observed for riparian buffers and livestock exclusion fencing (or for any structural BMP) in the agricultural and rural regions of the watershed. Without structural BMP installation dates and/ or spatial locations it is very difficult to track milestones in water quality improvement.

Water quality management at the watershed scale can be a challenging task. Due to the large spatial extent of a watershed, management actions must be carefully prioritized to mitigate or prevent pollutant discharges into the stream. The recommendations provided here may improve monitoring and water quality restoration activities for reducing bacteria in the Johnson Creek watershed. 


\section{Literature Cited}

Atwill, E., Dahlgren, R. and Knox, A., 2007. Management reduces E. coli in irrigated pasture runoff. California Agriculture, 61(4), pp.159-165.

Bamberg, S. and Möser, G., 2007. Twenty years after Hines, Hungerford, and Tomera: A new meta-analysis of psycho-social determinants of pro-environmental behaviour. Journal of environmental psychology, 27(1), pp.14-25.

Benham, B.L., Baffaut, C., Zeckoski, R.W., Mankin, K.R., Pachepsky, Y.A., Sadeghi, A.M., Brannan, K.M., Soupir, M.L. and Habersack, M.J., 2006. Modeling bacteria fate and transport in watersheds to support TMDLs. Transactions of the ASABE, 49(4), pp.987-1002.

BES (Bureau of Environmental Services), 1994. Johnson Creek Resource Management Plan. Technical Memorandum no. 4: 1-6.

BES (Bureau of Environmental Services), 2000. Integrated Watershed Plan Baseline Report.

BES (Bureau of Environmental Services), 2005. Johnson Creek Watershed Characterization.

BES (Bureau of Environmental Services), 2016. City of Portland Stormwater Management Manual

Cleland, B.R., 2003. TMDL Development from the "bottom up”-Part III: Duration Curves and wet-weather assessments. Proceedings of the Water Environment Federation, 2003(4), pp.1740-1766.

Copeland, C., 1999. Clean Water Act: a summary of the law. Washington, DC: Congressional Research Service, Library of Congress. 
Chen, H. J., and Heejun Chang, 2014. Response of discharge, TSS, and E. coli to rainfall events in urban, suburban, and rural watersheds. Environmental Science: Processes \& Impacts 16 no.10: 2313-2324.

City of Eugene, 2014. Development Standards Memorandum\#4 Water Quality Design Storm Selection. Eugene, Oregon

City of Gresham, 2008. TMDL Implementation Plan. Gresham, Oregon

City of Gresham, 2009. NPDES Annual Compliance Report Permit Year 14. Gresham, Oregon

City of Gresham, 2010. NPDES Annual Compliance Report Permit Year 15. Gresham, Oregon

City of Gresham, 2010. TMDL Annual Report. Gresham, Oregon

City of Gresham, 2011. NPDES Annual Compliance Report Permit Year 16. Gresham, Oregon

City of Gresham, 2011. TMDL Annual Report. Gresham, Oregon

City of Gresham, 2012. NPDES Annual Compliance Report Permit Year 17. Gresham, Oregon

City of Gresham, 2012. TMDL Annual Report. Gresham, Oregon

City of Gresham, 2013. NPDES Annual Compliance Report Permit Year 18. Gresham, Oregon

City of Gresham, 2013. TMDL Annual Report. Gresham, Oregon

City of Gresham, 2014. Five Year TMDL Review. Gresham, Oregon 
City of Gresham, 2014. NPDES Annual Compliance Report Permit Year 19. Gresham, Oregon

City of Gresham, 2014. Pollutant Load Evaluation 2014. Gresham, Oregon.

City of Gresham, 2014. TMDL Overview and Nonpoint Source TMDL Implementation Plans. Gresham, Oregon

City of Gresham, 2015. NPDES Annual Compliance Report Permit Year 20. Gresham, Oregon

City of Gresham, 2015. TMDL Annual Report. Gresham, Oregon

City of Gresham, 2016. NPDES Annual Compliance Report Permit Year 21. Gresham, Oregon

City of Gresham, 2016. TMDL Annual Report. Gresham, Oregon

City of Milwaukie, 2006. NPDES MS4 Discharge Permit 2005-2006 Annual Report. Milwaukie, Oregon

City of Milwaukie, 2007. NPDES MS4 Discharge Permit 2006-2007 Annual Report. Milwaukie, Oregon

City of Milwaukie, 2008. NPDES MS4 Discharge Permit 2007-2008 Annual Report. Milwaukie, Oregon

City of Milwaukie, 2009. NPDES MS4 Discharge Permit 2008-2009 Annual Report. Milwaukie, Oregon

City of Milwaukie, 2009. Stormwater Report: Milwaukie Riverfront Park 
City of Milwaukie, 2010. NPDES MS4 Discharge Permit 2009-2010 Annual Report. Milwaukie, Oregon

City of Milwaukie, 2011. NPDES MS4 Discharge Permit 2010-2011 Annual Report. Milwaukie, Oregon

City of Milwaukie, 2012. NPDES MS4 Discharge Permit 2011-2012 Annual Report. Milwaukie, Oregon

City of Milwaukie, 2013. NPDES MS4 Discharge Permit 2012-2013 Annual Report. Milwaukie, Oregon

City of Milwaukie, 2014. NPDES MS4 Discharge Permit 2013-2014 Annual Report. Milwaukie, Oregon

City of Milwaukie, 2014. TMDL Implementation Plan. Milwaukie, Oregon

City of Milwaukie, 2015. NPDES MS4 Discharge Permit 2014-2015 Annual Report. Milwaukie, Oregon

City of Milwaukie, 2016. NPDES MS4 Discharge Permit 2015-2016 Annual Report. Milwaukie, Oregon

City of Milwaukie, 2016. Pollutant Load Reduction Evaluation

City of Portland, 1996. NPDES Annual Report 1995-1996. Portland, Oregon.

City of Portland, 2006. NPDES Annual Report 2005- 2006. Portland, Oregon.

City of Portland, 2007. NPDES Annual Report 2006- 2007. Portland, Oregon.

City of Portland, 2008. NPDES Annual Report 2007- 2008. Portland, Oregon. 
City of Portland, 2008. TMDL Implementation Plan. Portland, Oregon

City of Portland, 2009. NPDES Annual Report 2008- 2009. Portland, Oregon.

City of Portland, 2009. TMDL Implementation Plan Informal Progress Report. Portland, Oregon

City of Portland, 2010. NPDES Annual Report 2009- 2010. Portland, Oregon.

City of Portland, 2010. TMDL Implementation Plan Second Annual Status Report. Portland, Oregon

City of Portland, 2011. NPDES Annual Report 2010- 2011. Portland, Oregon.

City of Portland, 2011. TMDL Implementation Plan Third Annual Status Report. Portland, Oregon

City of Portland, 2012. NPDES Annual Report 2011- 2012. Portland, Oregon.

City of Portland, 2012. TMDL Implementation Plan Fourth Annual Status Report. Portland, Oregon

City of Portland, 2013. NPDES Annual Report 2012- 2013. Portland, Oregon.

City of Portland, 2014. NPDES Annual Report 2013- 2014. Portland, Oregon.

City of Portland, 2014. TMDL Implementation Plan. Portland, Oregon

City of Portland, 2014. TMDL Implementation Plan Sixth Annual Status Report. Portland, Oregon 
City of Portland, 2015. NPDES Annual Report 2014- 2015. Portland, Oregon.

City of Portland, 2015. TMDL Implementation Plan Seventh Annual Status Report. Portland, Oregon

City of Portland, 2016. NPDES Annual Report 2015- 2016. Portland, Oregon.

City of Portland, 2016. Stormwater Management Manual. Portland, Oregon.

City of Portland, 2016. TMDL Implementation Plan Eighth Annual Status Report. Portland, Oregon

Clary, J., Jones, J., Urbonas, B., Quigley, M., Strecker, E. and Wagner, T., 2008. Can stormwater BMPs remove bacteria? New findings from the international stormwater BMP database. Stormwater Magazine May, pp.1-14.

Cohen, A. and Davidson, S., 2011. The watershed approach: Challenges, antecedents, and the transition from technical tool to governance unit. Water alternatives, 4(1), p.1.

Culver, T.B., Jia, Y., Tikoo, R., Simsic, J. and Garwood, R., 2002. Development of the Total Maximum Daily Load (TMDL) for fecal coliform bacteria in Moore's Creek, Albemarle County, Virginia.

Dayyani, S, Mohammadi, K. and Najib, H.R, 2003. River Flow Estimation for Ungauged Stations Using GIS Model.

DEQ (Department of Environmental Quality), 2016. Mid-Coast Basin Bacteria Technical Working Group Load Duration Curves (LDC) DRAFT Results Review: Upper Yaquina River

EPA (U.S. Environmental Protection Agency), 1999. Preliminary data summary of urban storm water best management practices, Chapter 5: Document No. EPA-821-R-99-012, p. 1-85, URL http://www.epa.gov/guide/stormwater/files/usw_c.pdf. 
EPA (U.S. Environmental Protection Agency), 2007. An approach for using Load Duration Curves in the Development of TMDLs. Washington: Environmental Protection Agency.

Eckner, K.F., 1998. Comparison of membrane filtration and multiple-tube fermentation by the Colilert and Enterolert methods for detection of waterborne coliform bacteria, Escherichia coli, and enterococci used in drinking and bathing water quality monitoring in southern Sweden. Applied and Environmental Microbiology, 64(8), pp.3079-3083.

FHWA, 2000. Stormwater Best Management Practices in an Ultraurban Setting:

Selection and Monitoring. Federal Highway Administration n. FHWA-EP-00e002. U.S. Department of Transportation, Washington, 287 pp.

Field, R. and Tafuri, A.N. eds., 2006. The use of best management practices (BMPs) in urban watersheds. DEStech Publications, Inc.

Franzetti, S.M., 2005. Background and History of Stormwater Regulations. Sponsored by Lorman Education Services: Oak Brook, IL.

GAO (U.S. Government Accountability Office), 2004. Watershed management: better coordination of data collection efforts needed to support key decisions. Report to the Chairman, Subcommittee on Water Resources and Environment, Committee on Transportation and Infrastructure, U.S. House of Representatives. GAO, GAO- 04-382, Washington, D.C.

Gianfagna, C.C., Johnson, C.E., Chandler, D.G. and Hofmann, C., 2015. Watershed area ratio accurately predicts daily streamflow in nested catchments in the Catskills, New York. Journal of Hydrology: Regional Studies, 4, pp.583-594.

Gray, S.S., Brown, C., Haimann, R. and Quinn, A., 2015. Non-Structural Best Management Practice Pollutant Load Reduction Estimation Method. Proceedings of the Water Environment Federation, 2015(17), pp.5193-5210.

Harmel, R. D., Raghupathy Karthikeyan, Terry Gentry, and Rajani Srinivasan, 2010. Effects of agricultural management, land use, and watershed scale on E. coli 
concentrations in runoff and streamflow. Transactions of the ASABE53, no. 6: 18331841.

Hathaway, J. M., W. F. Hunt, and S. Jadlocki, 2009. Indicator bacteria removal in stormwater best management practices in Charlotte, North Carolina. Journal of Environmental Engineering 135, no. 12: 1275-1285.

Hottenroth, D., Harper, C. and Turner, J., 1999. Effectiveness of Integrated Stormwater Management in a Portland, Oregon, Watershed. JAWRA Journal of the American Water Resources Association, 35(3), pp.633-641.

Hutchinson, D., Abrams, P., Retzlaff, R. and Liptan, T., 2003. Stormwater monitoring two ecoroofs in Portland, Oregon, USA. City of Portland Bureau of Environmental Services.

Jamieson R, et al. 2005. Transport and deposition of sediment-associated Escherichia coli in natural streams. Water Research. 39 (12): 2665-2675.

JCCP.2012. Johnson Creek Acquisition Strategy: Investing in a Natural Area Network.

Jenkinson, R., Wildensee, F., Lindbo, T., Stonewall, A., DiLeone, J., Nagy, J., Swanson, A., Iwai, R., Drake, D. and Larenas, M., 2014. Bacteria Source Tracking in Johnson Creek and Major Tributaries.

Kang, J.H., Debats, S.R. and Stenstrom, M.K., 2009. Storm-water management using street sweeping. Journal of Environmental Engineering, 135(7), pp.479-489.

Leopold, L.B. 1994. A View of the River. Harvard University Press. Cambridge, MA.

Meals, D.W., Dressing, S.A., and Davenport, T.E. 2009. Lag Time in Water Quality Response to Best Management Practices: A Review. American Society of Agronomy. Vol 39(1): pgs. 85-96. doi: 10.2134/jeq2009.0108

Multnomah County, 2014. NPDES Pollutant Reduction Analysis 
ODA (Oregon Department of Agriculture), 2007. East Multnomah SWCD and

Clackamas County SWCD Activity Report 2003-2006

ODA (Oregon Department of Agriculture), 2009. Area Plan goals and progress of Area Plan implementation 2007 - 2009

ODA (Oregon Department of Agriculture), 2011. Area Plan goals and progress of Area Plan implementation 2009 - 2011

ODA (Oregon Department of Agriculture), 2015. Biennial Review Summary Report

ODA (Oregon Department of Agriculture), 2017. Lower Willamette Agricultural Water Quality Management Area Plan.

ODEQ (Oregon Department of Environmental Quality), 2006. Chapter 5: Lower Willamette Subbasin TMDL

ODEQ (Oregon Department of Environmental Quality), 2006. Chapter 2: Willamette Basin Bacteria TMDL

Perdek, J.M., Arnone, R.D., Stinson, M.K. and Tuccillo, M.E., 2003. Managing Urban Watershed Pathogen Contamination. US Environmental Protection Agency, Office of Research and Development. EPA 600-R-03-111

Rifai, Hanadi. 2006. Study on the effectiveness of BMPs to control bacteria loads. Prepared by University of Houston for TCEQ as Final Quarterly Report 1.

Schueler, T.R., 1987. Controlling urban runoff: A practical manual for planning and designing urban BMPs. Water Resources Publications.

Schweitzer, N.A. 2013. Greening the Streets: A Comparison of Sustainable Stormwater Management in Portland, Oregon and Los Angeles, California. 
Seattle Public Utilities and Herrera Environmental Consultants, 2009. Seattle Street Sweeping Pilot Study Monitoring Report. Seattle, Washington

Sharma B.R. and Scott C.A.2005. Watershed management challenges: Introduction and overview. Watershed Management Challenges, p.1.

Walker, K.P. and DeGuida, R.N., 1995. Urban runoff and combined sewer overflow. Water environment research, 67(4), pp.414-419.

WES (Water Environment Services), 2011. Willamette River Watershed Total Maximum Daily Load Implementation Plan

WES (Water Environment Services), 2014. Willamette River Watershed Total Maximum Daily Load Annual Report

WES (Water Environment Services), 2015. TMDL Pollutant Load Reduction Evaluation

WES (Water Environment Services), 2015. Willamette River Watershed Total Maximum Daily Load Annual Report

WES (Water Environment Services), 2016. Willamette River Watershed Total Maximum Daily Load Annual Report

Williams, D.R., 2002. When Voluntary, Incentive-Based Controls Fail: Structuring a Regulatory Response to Agricultural Nonpoint Source Water Pollution. 


\section{Appendix}
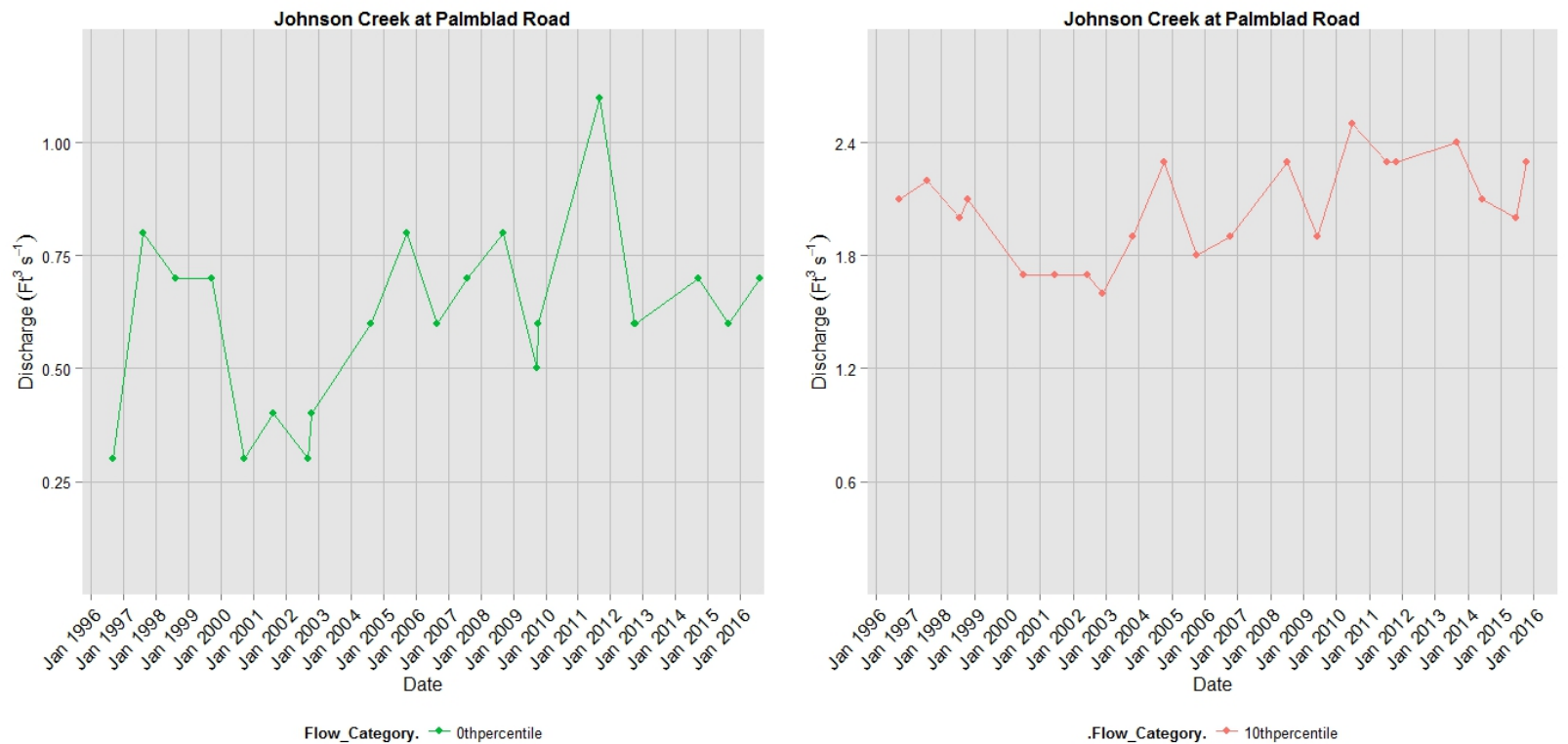

Figure 36. Time series plot of $0^{\text {th }}$ and $10^{\text {th }}$ percentile discharge events at Palmblad Road for water years (Oct 1 - Sept 30) 1996-2016.
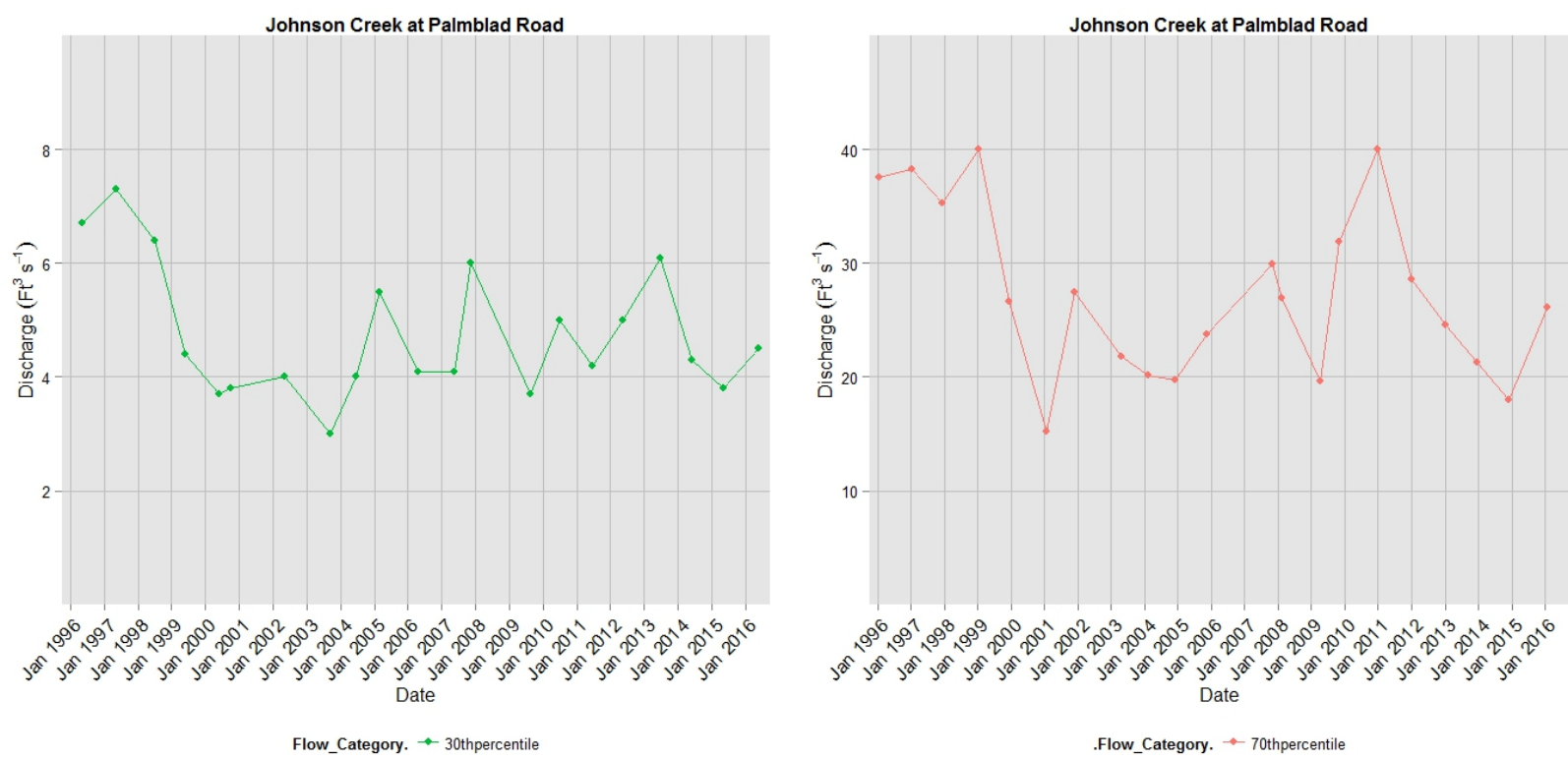

Figure 37. Time series plot of $30^{\text {th }}$ and $70^{\text {th }}$ percentile discharge events at Palmblad Road for water years (Oct 1- Sept 30) $1996-2016$. 

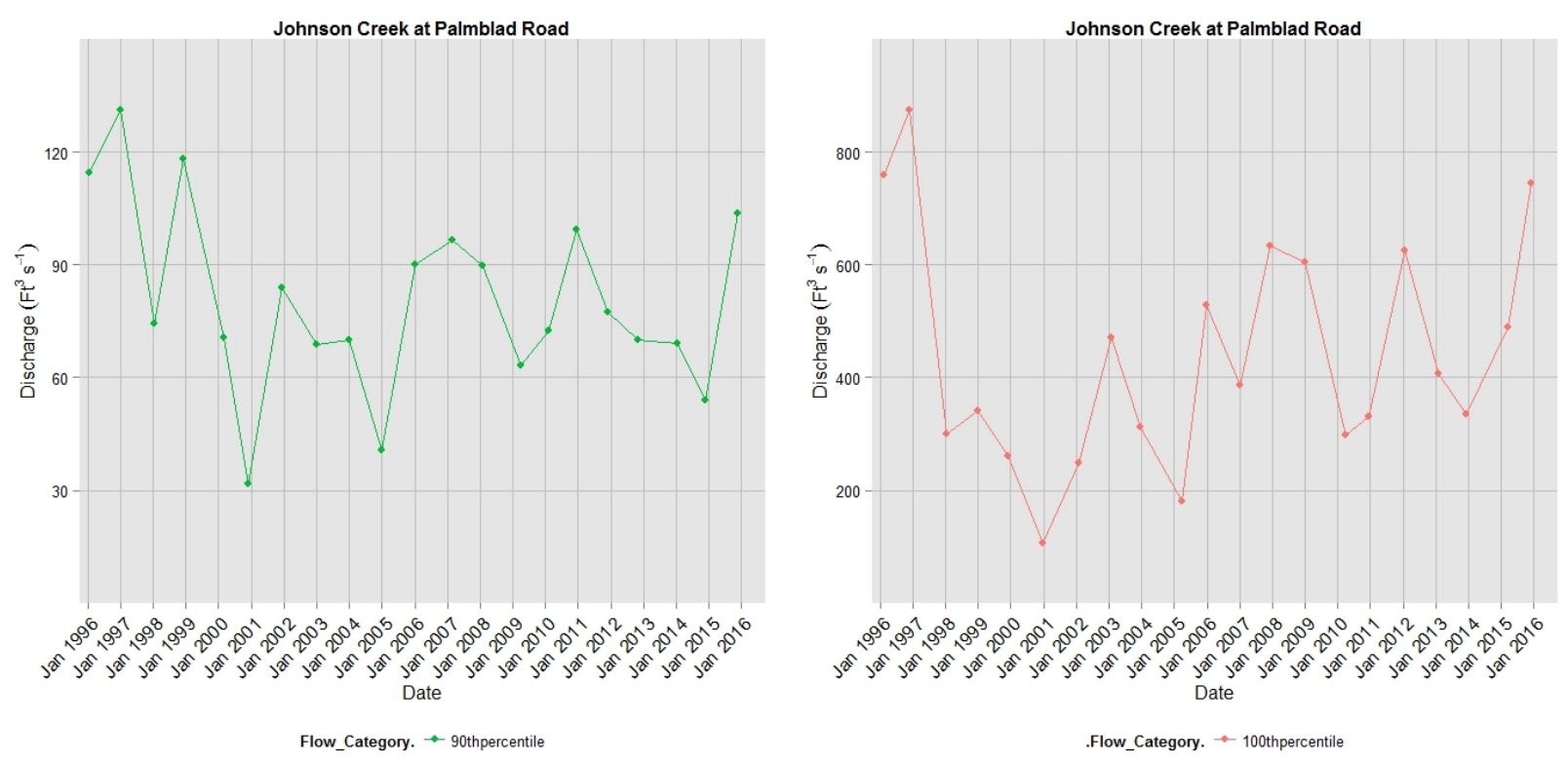

Figure 38. Time series plot of $90^{\text {th }}$ and $100^{\text {th }}$ percentile discharge events at Palmblad Road for water years (Oct 1- Sept 30) 1996-2016.

Table 47. Mann Kendall results for time series data for $0^{\text {th }}, 10^{\text {th }}, 30^{\text {th }}, 70^{\text {th }}, 90^{\text {th }}$, and $100^{\text {th }}$ percentile discharge events at Palmblad Road for water years (Oct 1- Sept 30) 1996-2016.

\begin{tabular}{|c|c|c|c|c|c|}
\hline Station & $\begin{array}{l}\text { Water Years } \\
\text { (Oct-Sept) }\end{array}$ & $\begin{array}{l}\text { Flow Range } \\
\left(\mathrm{Ft}^{3} / \mathrm{s}\right)\end{array}$ & Kendall Tau & $\begin{array}{l}\text { Two-Side p- } \\
\text { value }\end{array}$ & $\begin{array}{l}\text { Trend Slope } \\
\left(\mathrm{Ft}^{3} / \mathrm{s} / \mathrm{yr}\right)\end{array}$ \\
\hline \multirow{12}{*}{$\begin{array}{l}\text { Palmblad Road } \\
\text { (Estimated) }\end{array}$} & \multicolumn{5}{|c|}{ Annual minimum daily mean streamflow $\left(Q_{0}\right)$} \\
\hline & 1996-2016 & $0.3-1.1$ & 0.217 & 0.204 & 0.012 \\
\hline & \multicolumn{5}{|c|}{ Annual $10^{\text {th }}$ percentile daily mean streamflow $\left(Q_{10}\right)$} \\
\hline & 1996-2016 & $1.6-2.5$ & 0.3 & $0.07 *$ & 0.017 \\
\hline & \multicolumn{5}{|c|}{ Annual $30^{\text {th }}$ percentile daily mean streamflow $\left(Q_{30}\right)$} \\
\hline & $1996-2016$ & $3-7.3$ & -0.0434 & 0.808 & -0.013 \\
\hline & \multicolumn{5}{|c|}{ Annual $70^{\text {th }}$ percentile daily mean streamflow $\left(Q_{70}\right)$} \\
\hline & 1996-2016 & $15-40$ & -0.234 & 0.147 & -0.485 \\
\hline & \multicolumn{5}{|c|}{ Annual $90^{\text {th }}$ percentile daily mean streamflow ( $\left.Q_{90}\right)$} \\
\hline & $1996-2016$ & $32-131$ & -0.167 & 0.304 & -0.983 \\
\hline & \multicolumn{5}{|c|}{ Annual maximum daily mean streamflow $\left(Q_{100}\right)$} \\
\hline & $1996-2016$ & $106-876$ & 0.152 & 0.349 & 1.64 \\
\hline
\end{tabular}

Note:

$90 \%$ significance level $=*$ $95 \%$ significance level $=* *$ $99 \%$ significance level $=* * *$ 

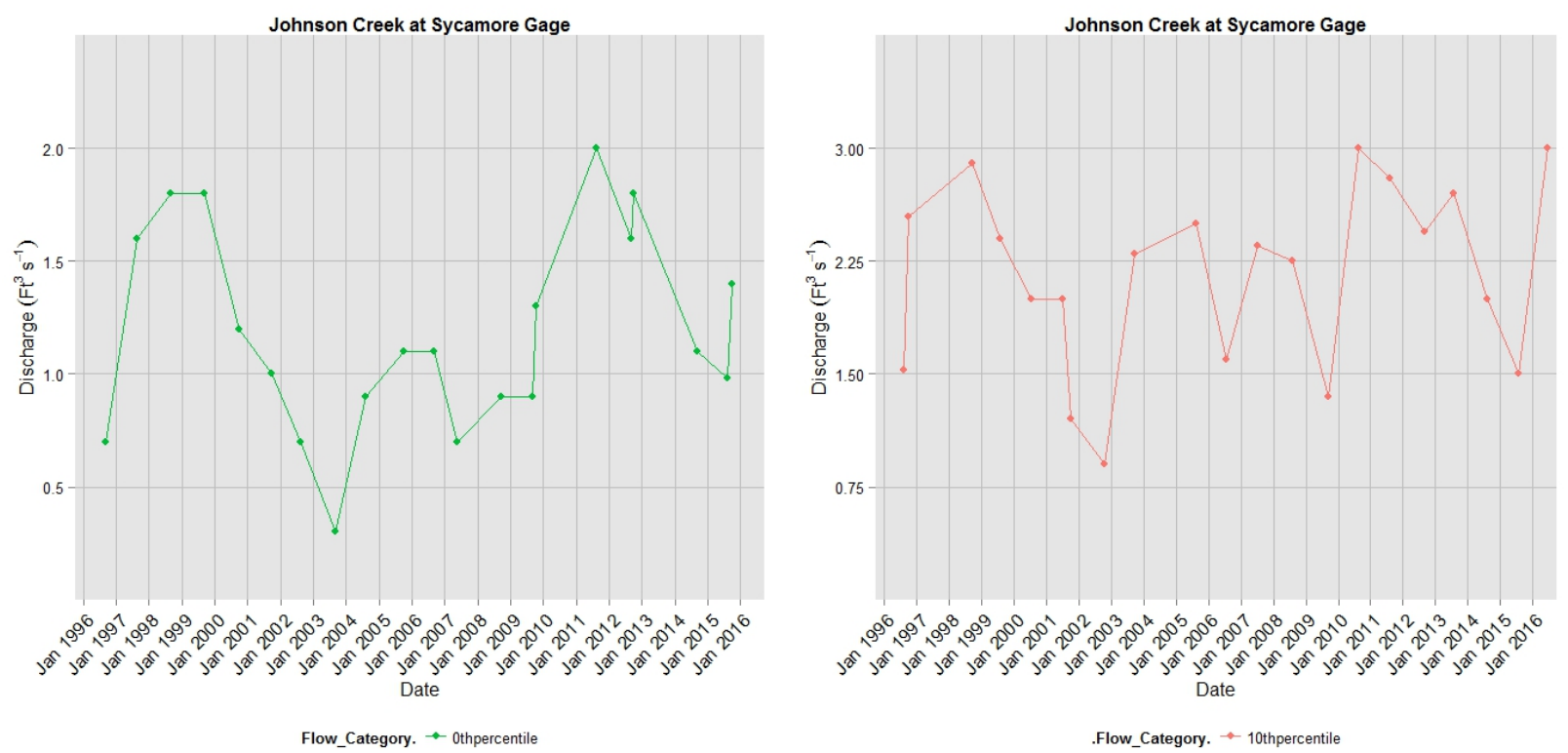

Figure 39. Time series plot of $0^{\text {th }}$ and $10^{\text {th }}$ percentile discharge events at Sycamore gauge for water years (Oct 1- Sept 30) 1996-2016.
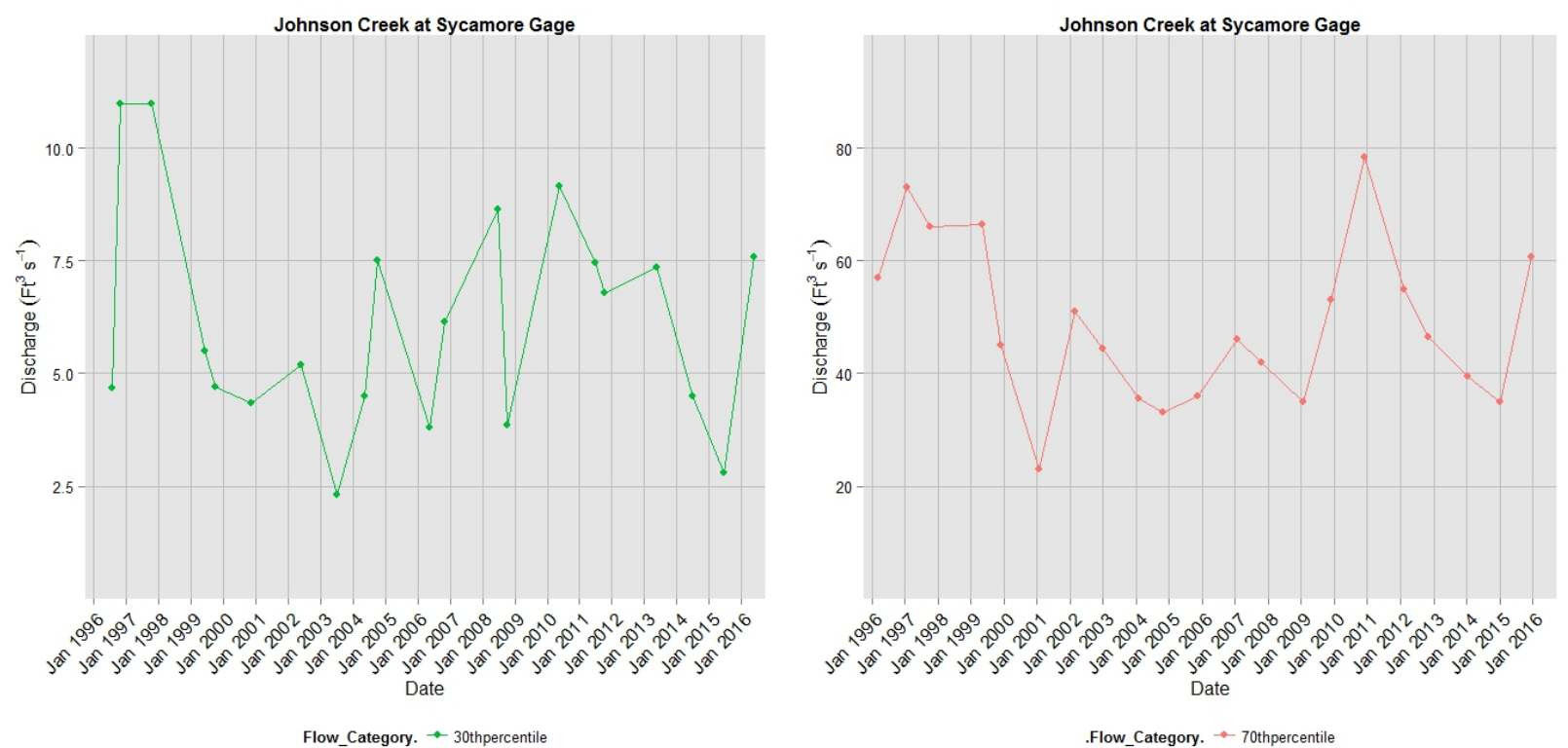

Figure 40. Time series plot of $30^{\text {th }}$ and $70^{\text {th }}$ percentile discharge events at Sycamore gauge for water years (Oct 1- Sept 30) 1996-2016. 

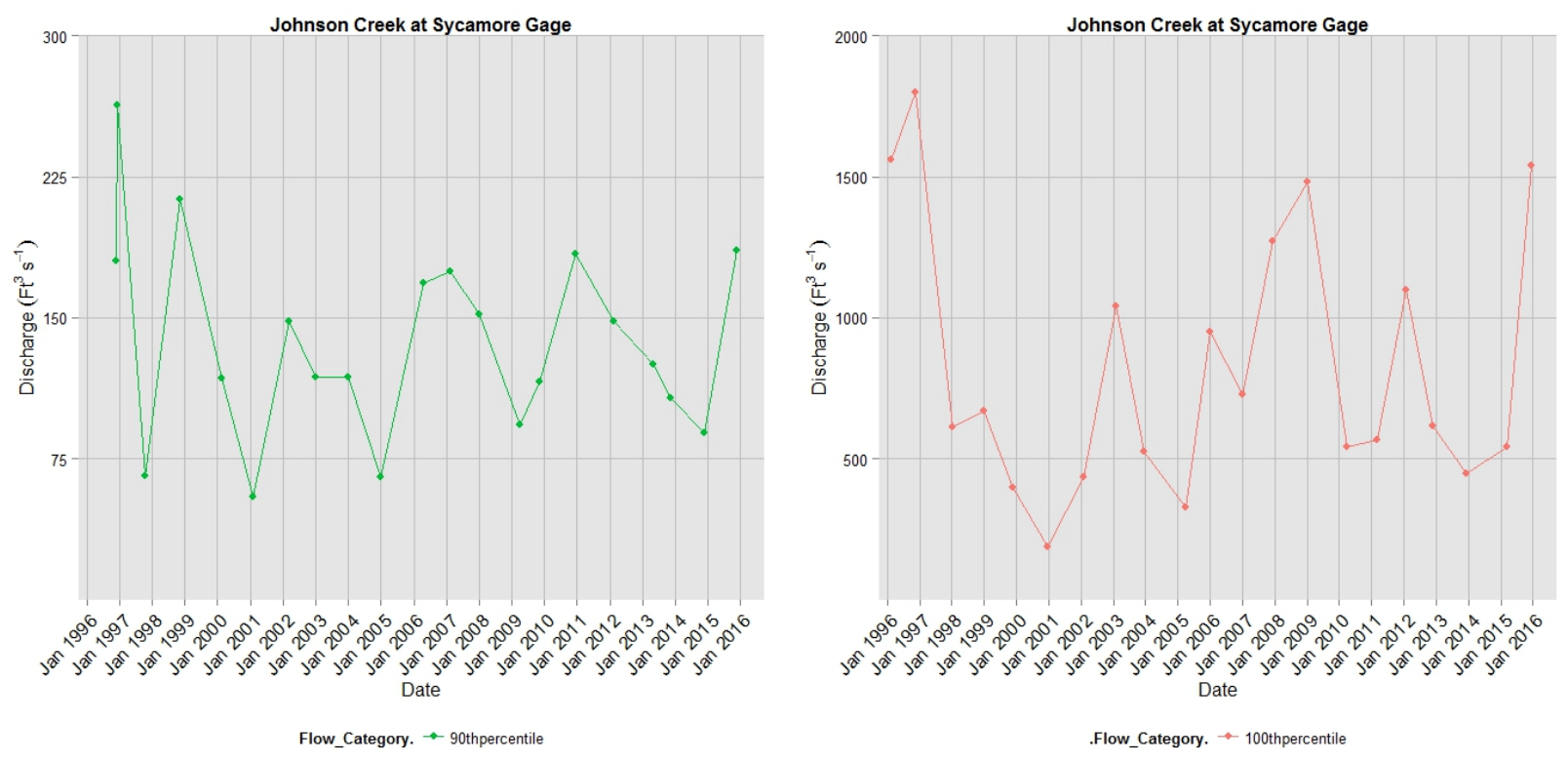

Figure 41. Time series plot of $90^{\text {th }}$ and $100^{\text {th }}$ percentile discharge events at Sycamore gauge for water years (Oct 1- Sept 30) 1996-2016.

Table 48. Mann Kendall results for time series data for $0^{\text {th }}, 10^{\text {th }}, 30^{\text {th }}, 70^{\text {th }}, 90^{\text {th }}$, and $100^{\text {th }}$ percentile discharge events at Sycamore Gauge for water years (Oct 1- Sept 30) 1996-2016.

\begin{tabular}{|c|c|c|c|c|c|}
\hline Station & $\begin{array}{l}\text { Water Years } \\
\text { (Oct-Sept) }\end{array}$ & $\begin{array}{l}\text { Flow Range } \\
\left(\mathrm{Ft}^{3} / \mathrm{s}\right)\end{array}$ & Kendall Tau & $\begin{array}{l}\text { Two-Side p- } \\
\text { value }\end{array}$ & $\begin{array}{l}\text { Trend Slope } \\
\left(\mathrm{Ft}^{3} / \mathrm{s} / \mathrm{yr}\right)\end{array}$ \\
\hline \multirow{12}{*}{$\begin{array}{l}\text { Sycamore Road } \\
\text { Gauge }\end{array}$} & \multicolumn{5}{|c|}{ Annual minimum daily mean streamflow $\left(\mathrm{Q}_{0}\right)$} \\
\hline & 1996-2016 & $0.3-2$ & 0.113 & 0.503 & 0.013 \\
\hline & \multicolumn{5}{|c|}{ Annual $10^{\text {th }}$ percentile daily mean streamflow $\left(Q_{10}\right)$} \\
\hline & 1996-2016 & $0.9-3$ & 0.115 & 0.486 & 0.021 \\
\hline & \multicolumn{5}{|c|}{ Annual $30^{\text {th }}$ percentile daily mean streamflow $\left(Q_{30}\right)$} \\
\hline & $1996-2016$ & $2.3-11$ & -0.029 & 0.878 & -0.012 \\
\hline & \multicolumn{5}{|c|}{ Annual $70^{\text {th }}$ percentile daily mean streamflow $\left(Q_{70}\right)$} \\
\hline & 1996-2016 & $23-79$ & -0.119 & 0.468 & -0.413 \\
\hline & \multicolumn{5}{|c|}{ Annual $90^{\text {th }}$ percentile daily mean streamflow $\left(Q_{90}\right)$} \\
\hline & $1996-2016$ & $55-263$ & -0.067 & 0.694 & -0.69 \\
\hline & \multicolumn{5}{|c|}{ Annual maximum daily mean streamflow $\left(Q_{100}\right)$} \\
\hline & $1996-2016$ & $186-1800$ & 0.029 & 0.879 & 1.27 \\
\hline
\end{tabular}

Note:

$90 \%$ significance level= * $95 \%$ significance level $=* *$ $99 \%$ significance level $=* * *$ 

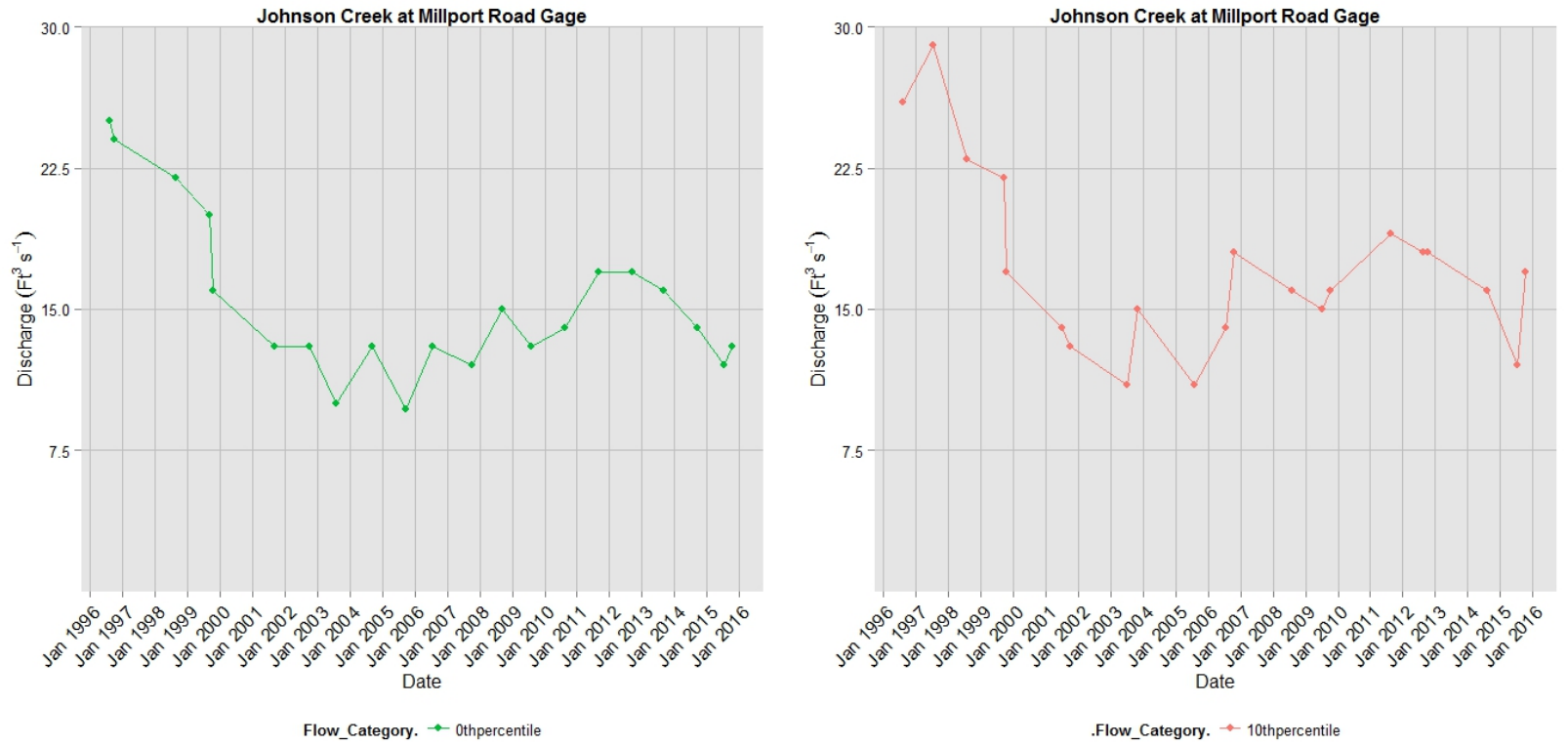

Figure 42. Time series plot of $0^{\text {th }}$ and $10^{\text {th }}$ percentile discharge events at Millport Rd. gauge for water years (Oct 1Sept 30) 1996-2016.
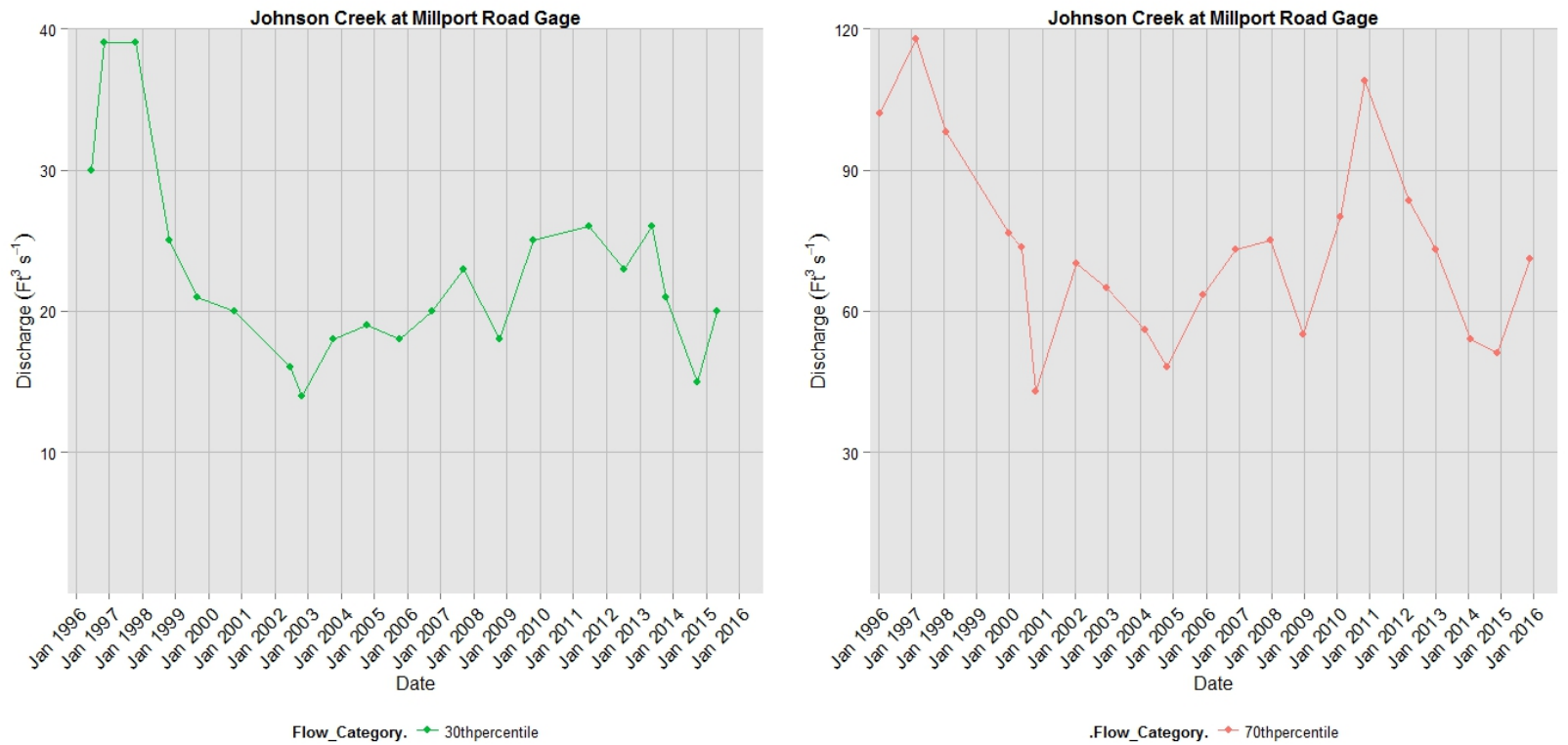

Figure 43. Time series plot of $30^{\text {th }}$ and $70^{\text {th }}$ percentile discharge events at Millport Rd. gauge for water years (Oct 1Sept 30) 1996-2016. 

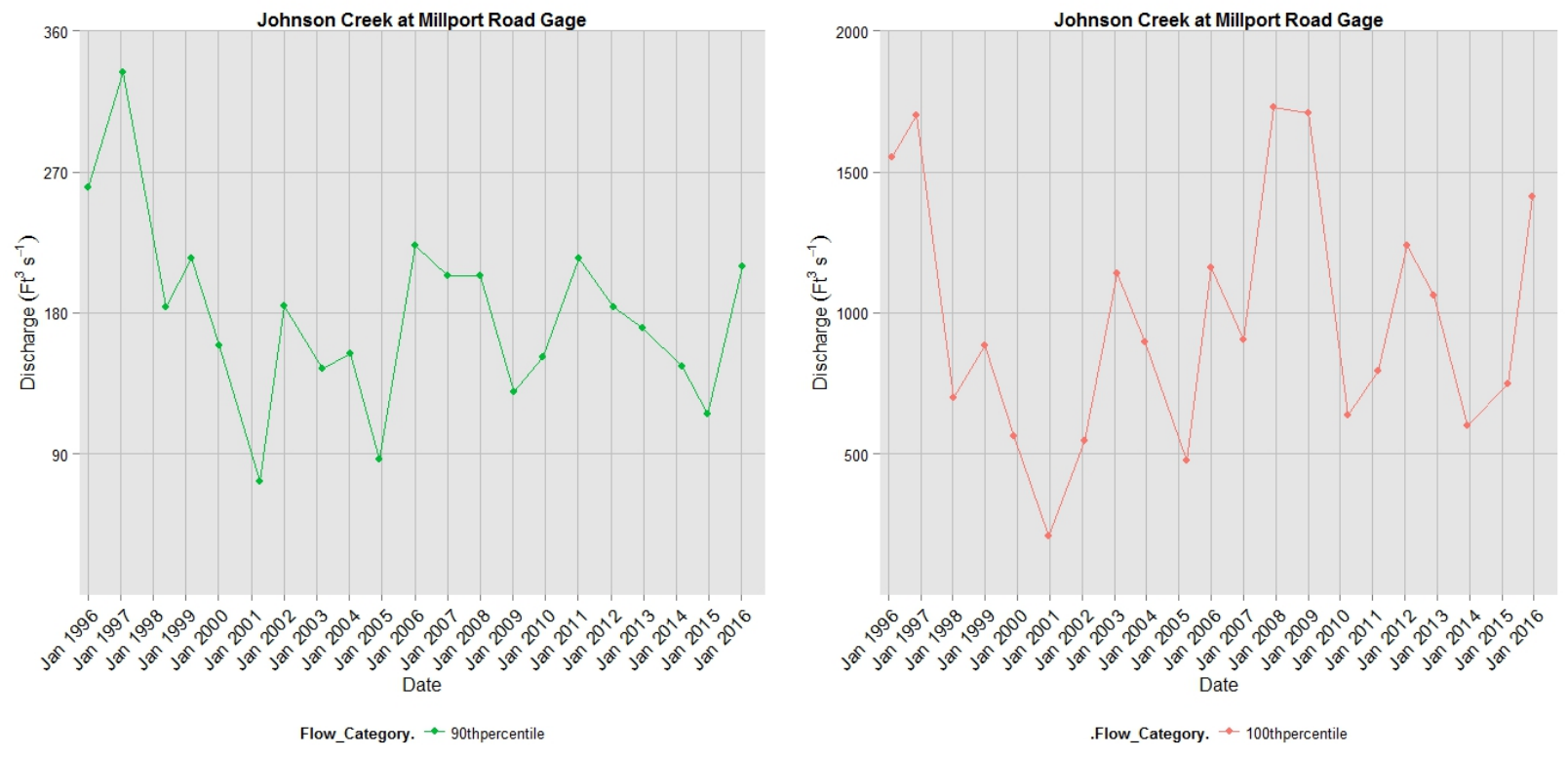

Figure 44. Time series plot of $90^{\text {th }}$ and $100^{\text {th }}$ percentile discharge events at Millport Rd. gauge for water years (Oct 1Sept 30) 1996-2016.

Table 49. Mann Kendall results for time series data for $0^{\text {th }}, 10^{\text {th }}, 30^{\text {th }}, 70^{\text {th }}, 90^{\text {th }}$, and $100^{\text {th }}$ percentile discharge events at Millport Rd. Gauge for water years (Oct 1- Sept 30) 1996-2016.

\begin{tabular}{|c|c|c|c|c|c|}
\hline Station & $\begin{array}{l}\text { Water Years } \\
\text { (Oct-Sept) }\end{array}$ & $\begin{array}{l}\text { Flow Range } \\
\left(\mathrm{Ft}^{3} / \mathrm{s}\right)\end{array}$ & Kendall Tau & $\begin{array}{l}\text { Two-Side p- } \\
\text { value }\end{array}$ & $\begin{array}{l}\text { Trend Slope } \\
\left(\mathbf{F t}^{3} / \mathbf{s} / \mathbf{y r}\right)\end{array}$ \\
\hline \multirow{3}{*}{$\begin{array}{l}\text { Millport Road } \\
\text { Gauge }\end{array}$} & \multicolumn{5}{|c|}{ Annual minimum daily mean streamflow $\left(Q_{0}\right)$} \\
\hline & $1996-2016$ & $9.7-25$ & -0.265 & 0.111 & -0.258 \\
\hline & \multicolumn{5}{|c|}{ Annual $10^{\text {th }}$ percentile daily mean streamflow $\left(Q_{10}\right)$} \\
\hline \multirow{9}{*}{$\begin{array}{l}\text { (Approximately } \\
\text { SE } 17^{\text {th }} \text { Ave ) }\end{array}$} & $1996-2016$ & $11-29$ & -0.166 & 0.316 & -0.286 \\
\hline & \multicolumn{5}{|c|}{ Annual $30^{\text {th }}$ percentile daily mean streamflow $\left(Q_{30}\right)$} \\
\hline & $1996-2016$ & $14-39$ & -0.152 & 0.362 & -0.27 \\
\hline & \multicolumn{5}{|c|}{ Annual $70^{\text {th }}$ percentile daily mean streamflow $\left(Q_{70}\right)$} \\
\hline & 1996-2016 & $43-118$ & -0.224 & 0.164 & -1.26 \\
\hline & \multicolumn{5}{|c|}{ Annual $90^{\text {th }}$ percentile daily mean streamflow $\left(Q_{90}\right)$} \\
\hline & $1996-2016$ & 73-334 & -0.191 & 0.238 & -2.40 \\
\hline & \multicolumn{5}{|c|}{ Annual maximum daily mean streamflow (Q 100$)$} \\
\hline & 1996-2016 & $207-1730$ & 0.067 & 0.694 & 3.69 \\
\hline
\end{tabular}

Note:

$90 \%$ significance level $=*$ $95 \%$ significance level $=* *$ $99 \%$ significance level $=* * *$ 